\title{
SOBRE O PROJETO DE EDIFÍCIOS EM ESTRUTURA MISTA AÇO-CONCRETO
}

Eng. Gerson Moacyr Sisniegas Alva

Dissertação apresentada à Escola de Engenharia de São Carlos, da Universidade de São Paulo, como parte dos requisitos para a obtenção do título de Mestre em Engenharia de Estruturas

Orientador: Prof. Dr. Maximiliano Malite

São Carlos

2000 
Aos meus pais, pelo constante incentivo e apoio. 


\section{AGRADECIMENTOS}

Inicialmente, agradeço a Deus, o criador de todas as coisas, sem o qual não poderia começar nem terminar este trabalho.

Ao professor Maximiliano Malite, pela amizade e pela orientação dispensada durante a elaboração deste trabalho.

À CAPES pela bolsa de estudos concedida, a qual possibilitou a realização deste trabalho.

Aos funcionários do departamento de estruturas, em especial à Nadir, pela orientação no trabalho de referências bibliográficas, e à Rosi, pela disponibilidade e atenção.

Aos colegas do departamento de estruturas, tanto pelos momentos de trabalho, quanto pelos momentos de descontração, os quais ficarão sempre em minhas lembranças.

Aos amigos Roberto, Yuri, Patrícia Lizi, Patrícia Garcia, Rodrigo, Rejane, Ana Cláudia, George e Valentim, pelo companheirismo destes anos em que convivemos juntos.

Aos meus pais Heli e Nora, pelo apoio e encorajamento que sempre me deram, e por quem tenho grande respeito.

À minha noiva Ana Carolina, pelo enorme carinho, incentivo e compreensão, durante a realização deste trabalho.

Enfim, deixo a minha gratidão a todos que participaram e contribuíram, direta ou indiretamente, na elaboração desta pesquisa. 


\section{SUMÁRIO}

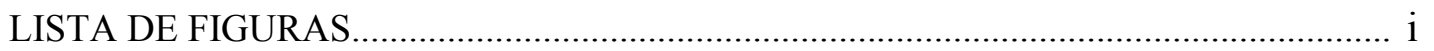

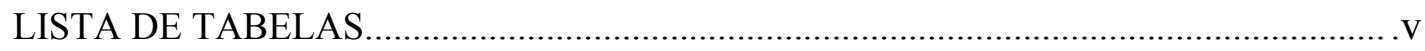

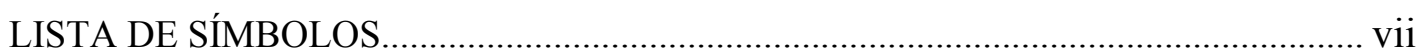

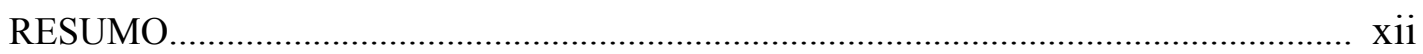

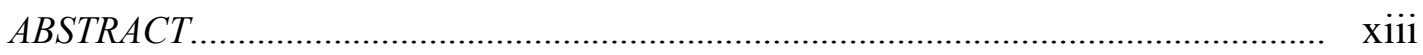

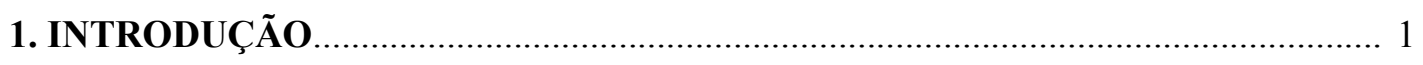

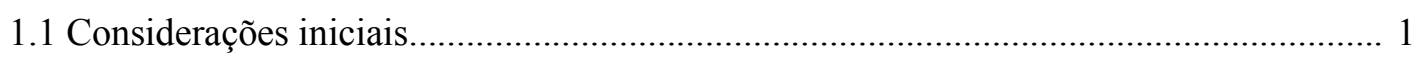

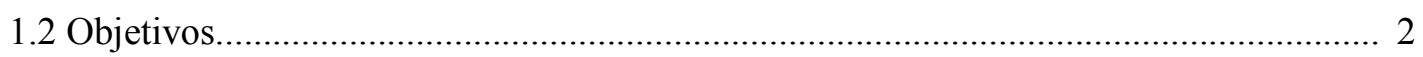

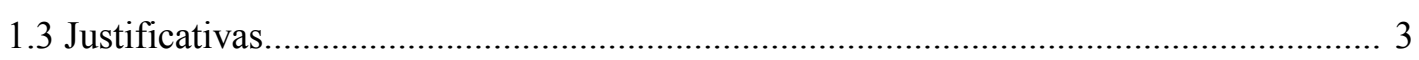

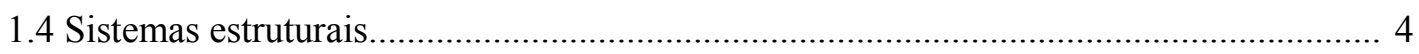

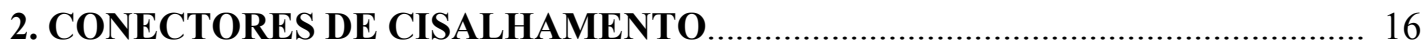

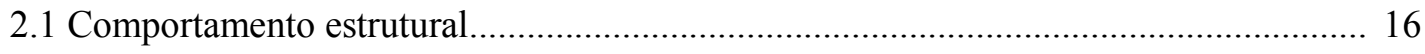

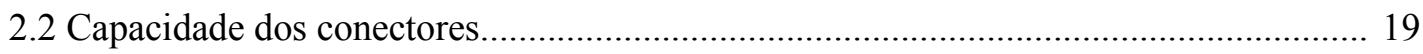

2.3 Recomendações e restrições segundo as normas....................................................... 27

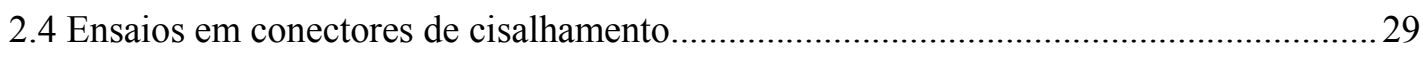

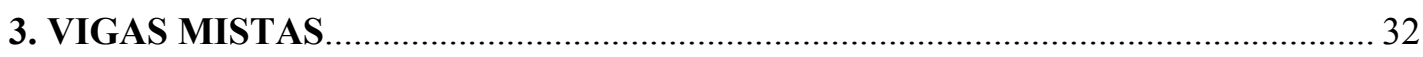

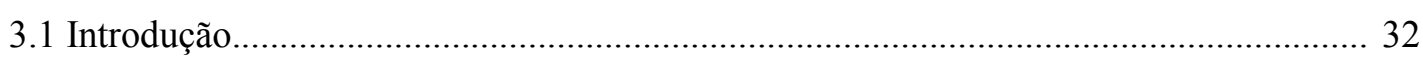

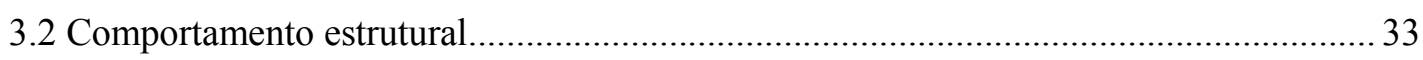

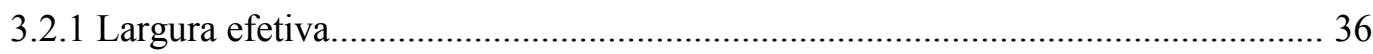

3.2.2 Efeito da fluência e da retração do concreto............................................................ 42

3.3 Dimensionamento segundo as principais normas.......................................................... 44

3.3.1 Resistência ao momento fletor: região de momentos positivos............................. 44

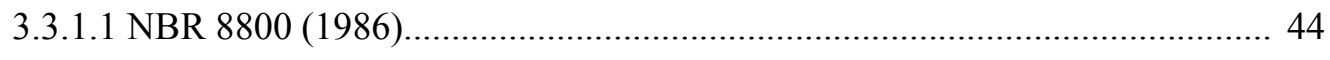

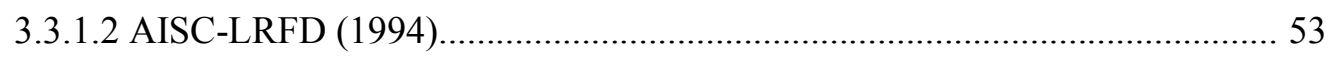

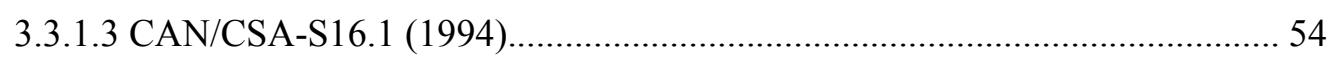

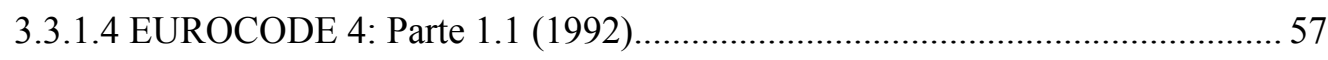

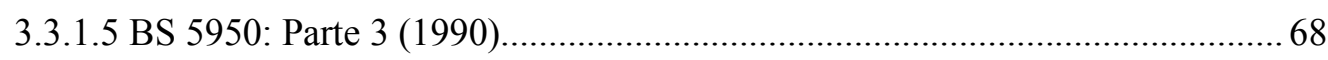

3.3.2 Resistência ao momento fletor: região de momentos negativos.............................. 74

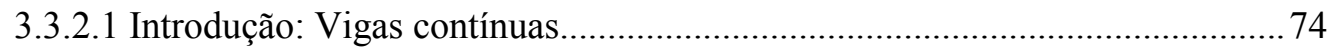

3.3.2.2 Fatores que influenciam a resistência ao momento fletor em vigas

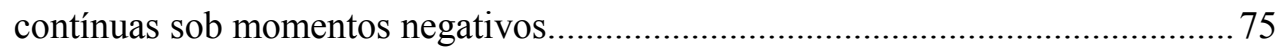

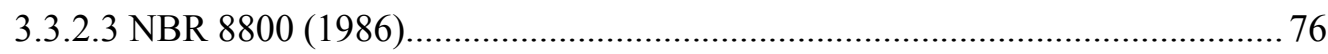




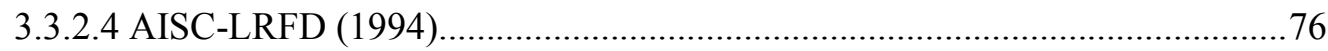

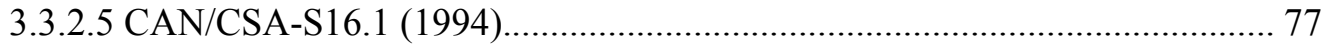

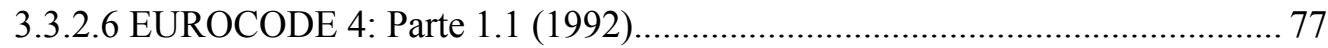

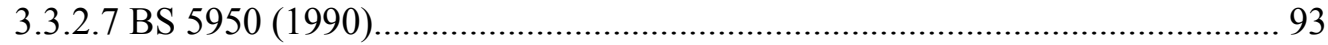

3.3.2.8 Considerações sobre o dimensionamento de viga mistas contínuas............... 97

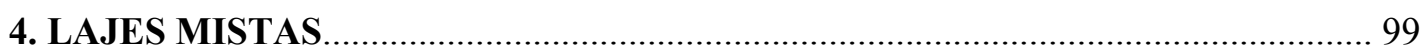

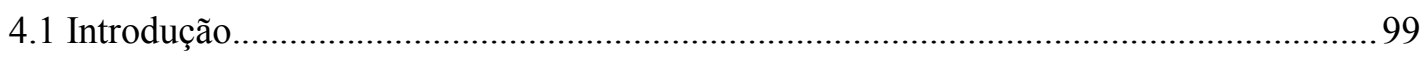

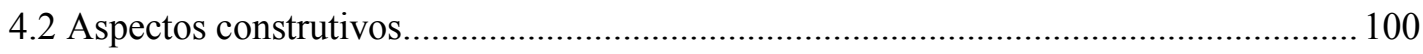

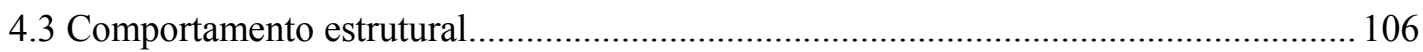

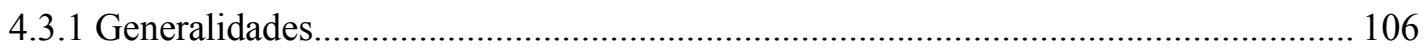

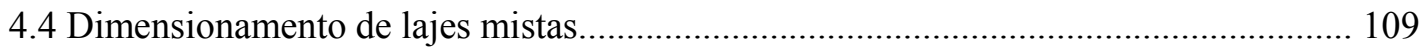

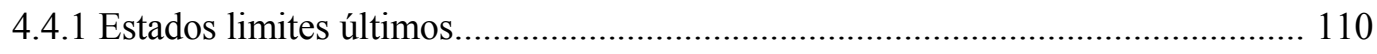

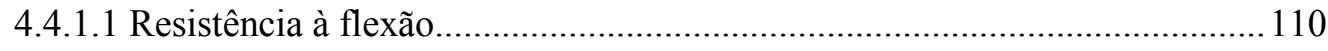

4.4.1.2 Resistência ao cisalhamento longitudinal....................................................113

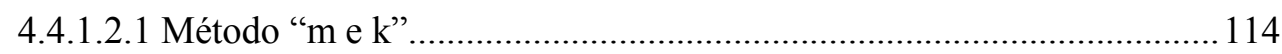

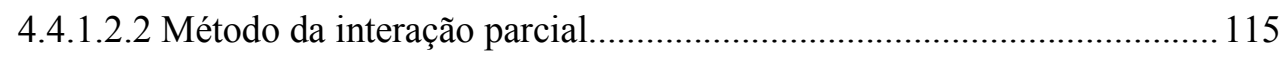

4.4.1.3 Resistência ao cisalhamento transversal........................................................120

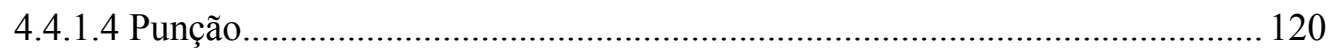

4.4.2 Estados limites de utilização............................................................................ 122

4.4.2.1 Deslocamento relativo de extremidade..................................................... 122

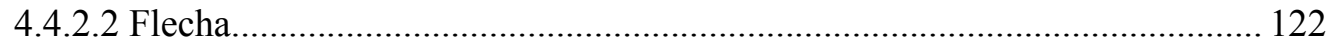

4.4.2.3 Fissuração no concreto............................................................................... 124

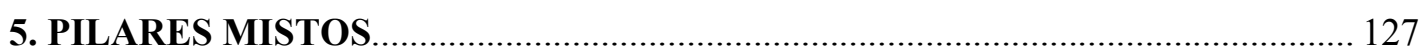

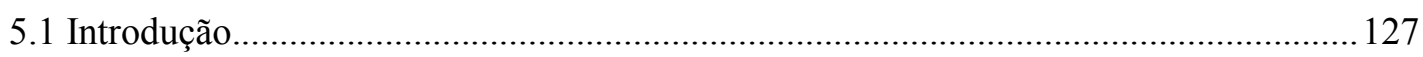

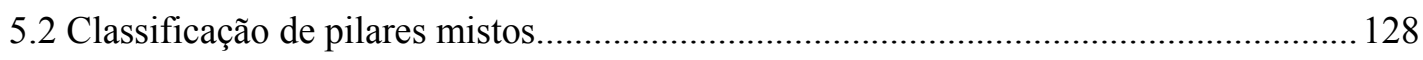

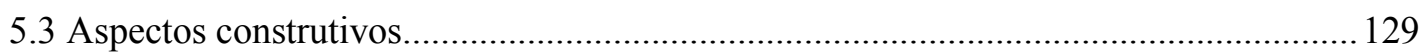

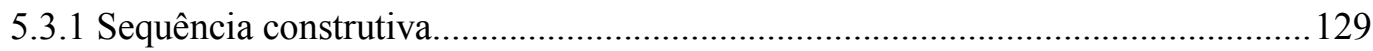

5.3.2 Ligações entre vigas e pilares mistos.................................................................. 132

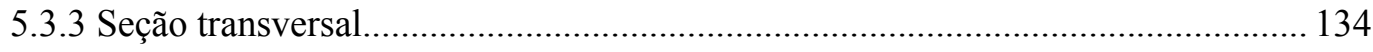

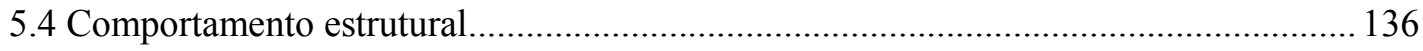

5.5 Dimensionamento segundo as principais normas........................................................141

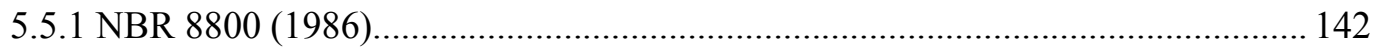

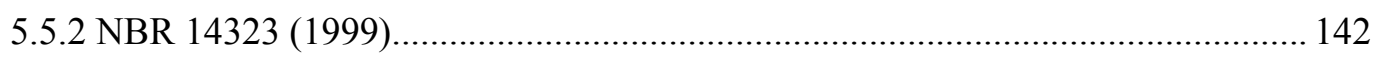

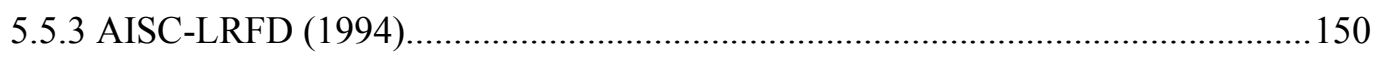

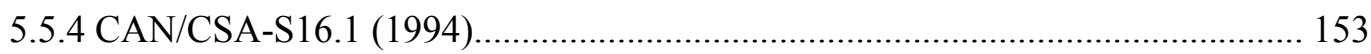


5.5.5 EUROCODE 4: Parte 1.1 (1992)...

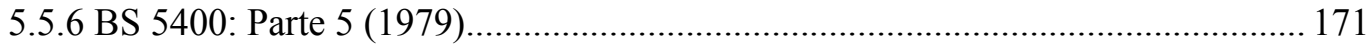

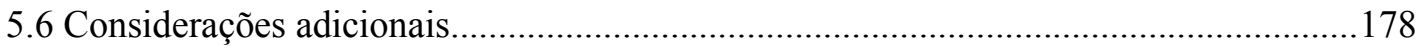

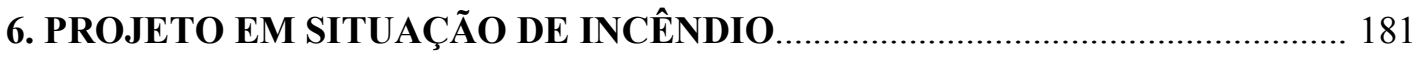

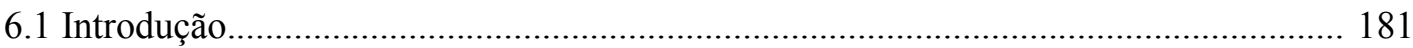

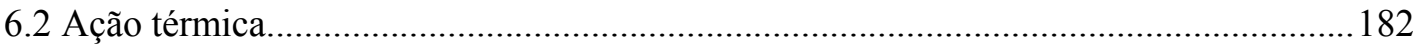

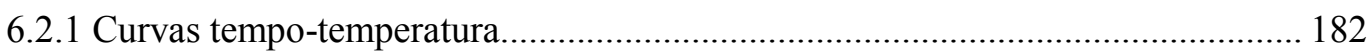

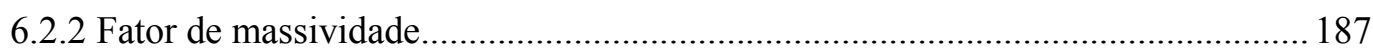

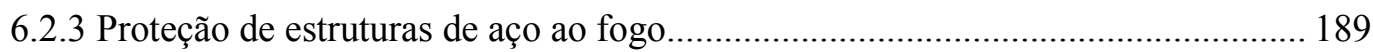

6.3 Propriedades mecânicas do aço e do concreto sob temperaturas elevadas.................... 191

6.4 Dimensionamento de estruturas de aço em situação de incêndio.....................................198

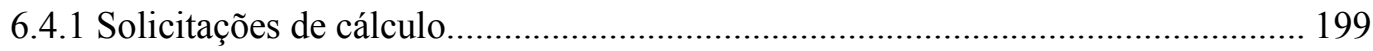

6.4.2 Resistência de elementos estruturais de aço...........................................................200

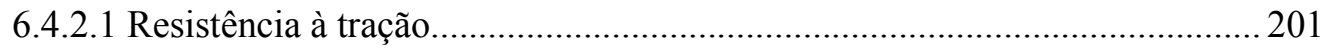

6.4.2.2 Resistência à compressão.......................................................................... 202

6.4.2.3 Resistência ao momento fletor...................................................................... 203

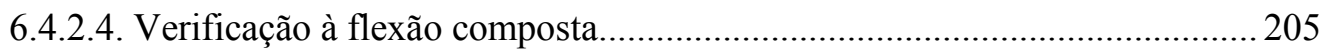

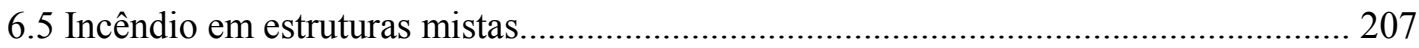

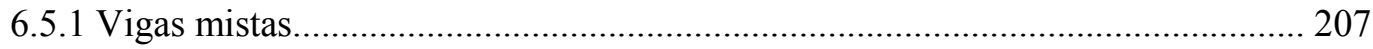

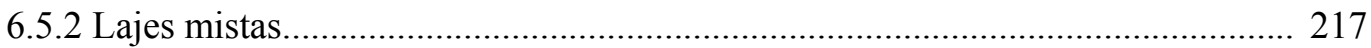

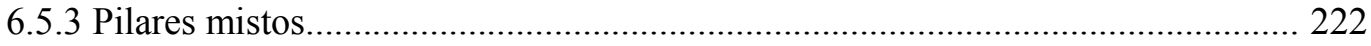

7. EXEMPLOS

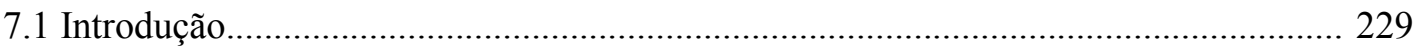

7.2 Exemplos de verificação de vigas mistas................................................................... 230

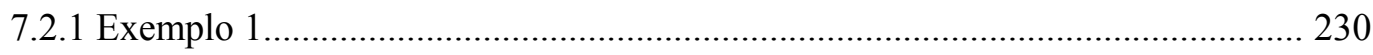

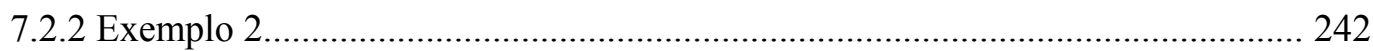

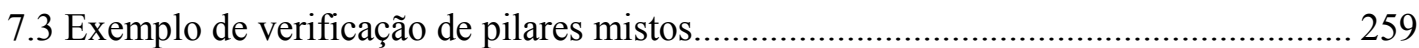

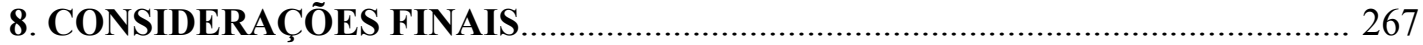

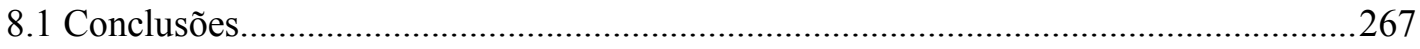

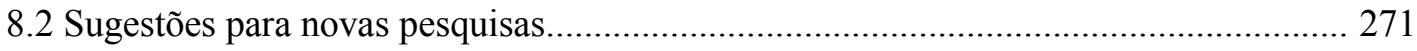

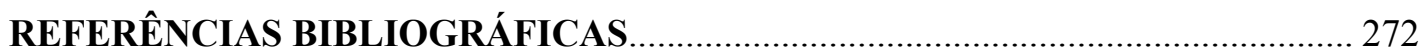




\section{LISTA DE FIGURAS}

FIGURA 1.1 - Aplicação do sistema misto em sistemas estruturais horizontais. 5

FIGURA 1.2 - Exemplo de aplicação do sistema de lajes mistas em edifício garagem.......... 6

FIGURA 1.3 - Exemplo de aplicação de lajes nervuradas pré-fabricadas em piso de edifício. 6

FIGURA 1.4 - Alguns tipos de sistemas verticais. CORRÊA (1991) .................................... 7

FIGURA 1.5 - Exemplo de aplicação do sistema em pórtico................................................ 9

FIGURA 1.6 - Exemplo de sistema de treliças em edifício de múltiplos andares.................. 10

FIGURA 1.7 - Edifício Cinevídeo Frame - Cotia/SP. Fonte: DIAS (1993).......................... 11

FIGURA 1.8 - Edifício Saraiva Marinho - Belo Horizonte/MG. Fonte: DIAS (1993)........ 11

FIGURA 1.9 - Esquema típico do sistema com núcleo central............................................12

FIGURA 1.10 - Exemplo de aplicação do sistema com núcleo estrutural de concreto em

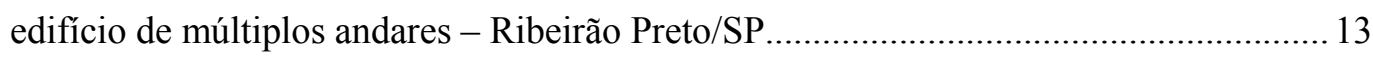

FIGURA 1.11 - Exemplo de aplicação dos sistemas tubulares............................................. 14

FIGURA 1.12 - Edifício Petronas Twin Tower - Kuala Lumpur, Malásia............................. 15

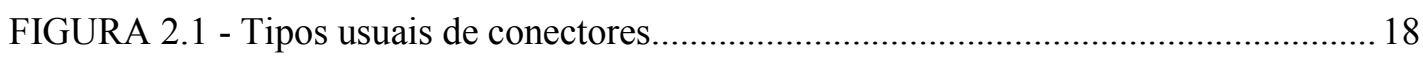

FIGURA 2.2 - Exemplos de tipos de conectores................................................................... 18

FIGURA 2.3 - Curva Força x Escorregamento para conectores de cisalhamento.................. 19

FIGURA 2.4 - Diagrama força x escorregamento para conectores do tipo pino com cabeça embutidos em laje maciças......................................................................... 19

FIGURA 2.5 - Lajes com fôrmas de aço incorporadas........................................................ 21

FIGURA 2.6 - Restrições relativas à locação e espaçamento de conectores segundo

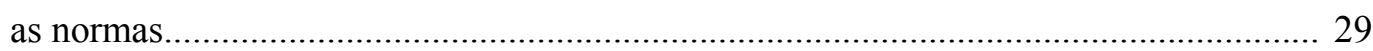

FIGURA 2.7 - Modelo adotado pelo EUROCODE 4 para o ensaio tipo push-out.............. 30

FIGURA 2.8 - Possíveis modos de colapso obtidos dos ensaios do tipo push-out................ 30

FIGURA 3.1 - Alguns tipos mais usuais de vigas mistas. MALITE (1990)....................... 32

FIGURA 3.2 - Interação aço-concreto no comportamento de vigas mistas......................... 34

FIGURA 3.3 - Distribuição das tensões longitudinais na laje considerando o

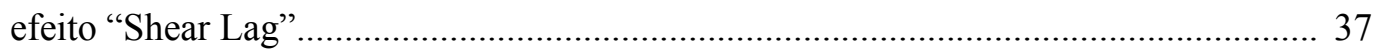

FIGURA 3.4 - Valores de $\mathrm{L}_{\mathrm{o}}$ para vigas contínuas segundo o EUROCODE 4..................... 40

FIGURA 3.5 - Exemplo de determinação da largura efetiva para vigas contínuas

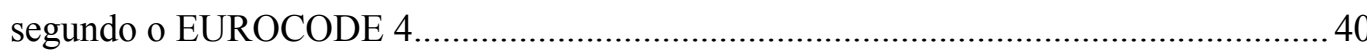


FIGURA 3.6 - Tensões em vigas mistas sob momento positivo -

Interação completa $\left(h_{w} / t_{w} \leq 3,5 \sqrt{E / f_{y}}\right)$.

FIGURA 3.7 - Deformações em vigas mistas sob momento positivo - Análise elástica/Interação completa.

FIGURA 3.8 - Distribuição de tensões em vigas mistas sob momento positivo Interação completa... 58

FIGURA 3.9 - Distribuição de tensões em vigas mistas sob momento positivo -

Interação parcial. 58

FIGURA 3.10 - Métodos de cálculo para interação parcial - EUROCODE 4 62

FIGURA 3.11 - Rigidez à flexão ao longo de uma viga mista contínua utilizada na obtenção de momentos fletores considerando-se a análise elástica. 78

FIGURA 3.12 - Distribuição de tensões em vigas mistas sob momento negativo. 81

FIGURA 3.13 - a) Flambagem lateral com torção; b) Instabilidade lateral associada à distorção da seção transversal da viga de aço; c) Pórtico em "U" invertido 85

FIGURA 4.1 - Exemplo do sistema de lajes mistas- Steel Deck CE-75 - Extraído do

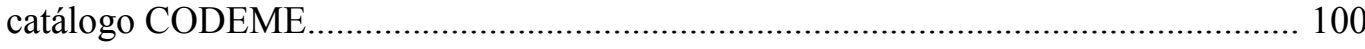

FIGURA 4.2 - Fôrmas típicas de ligação em lajes mistas... 101

FIGURA 4.3 - Dimensões típicas da fôrma de aço e da laje de concreto EUROCODE 4 (1992) 102

FIGURA 4.4 - Comprimentos mínimos de apoio - EUROCODE 4 (1992). 103

FIGURA 4.5 - Esquema típico de fixação preliminar e definitiva dos painéis nas vigas de aço. 104

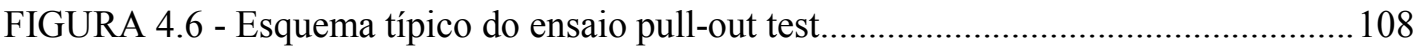

FIGURA 4.7 - Esquema típico do ensaio push-off test............................................................. 108

FIGURA 4.8 - Esquema típico do ensaio slip block test................................................... 109

FIGURA 4.9 - Distribuição de tensões para momentos positivos: Linha Neutra Plástica acima da fôrma de aço

FIGURA 4.10 - Distribuição de tensões para momentos positivos: Linha Neutra Plástica interceptando a fôrma de aço.

FIGURA 4.11 - Disposição do carregamento e geometria laje mista - Método "m e $\mathrm{k} "$

FIGURA 4.12 - Definição das constantes m e k e os possíveis modos de colapso. 115

FIGURA 4.13 - Determinação do grau de interação parcial ao cisalhamento adaptado do EUROCODE 4 (1992).

FIGURA 4.14 - Diagrama de interação parcial de cálculo. 
FIGURA 4.15 - Verificação da resistência ao cisalhamento.

FIGURA 4.16 - Perímetro crítico para o cisalhamento por punção

FIGURA 4.17 - Comportamento do deslizamento relativo de extremidade para vãos externos. 123

FIGURA 4.18 - Distribuição da carga concentrada.

FIGURA 5.1 - Exemplos de seções típicas de pilares mistos e dimensões características.

FIGURA 5.2 - Sistema estrutural final em pórticos mistos, segundo a proposta de VALLENILLA \& BJORHOVDE

FIGURA 5.3 - Detalhes de ligações de pilares mistos revestidos com vigas mistas.

FIGURA 5.4 - Esquema de ligações tipo A, investigadas por AZIZINAMINI \& PRAKASH (1993).

FIGURA 5.5 - Esquema de ligação tipo B, investigada por AZIZINAMINI \& PRAKASH (1993).

FIGURA 5.6 - Flambagem local para pilares mistos constituídos por perfis tubulares retangulares - UY (1998)

FIGURA 5.7 - Perfil "I" revestido com concreto e fletido em torno do eixo de maior inércia.

FIGURA 5.8 - Seção I revestida com concreto fletida em torno do eixo de menor inércia

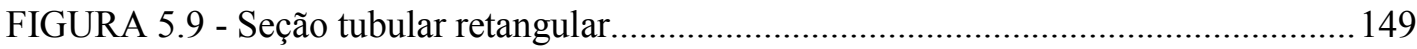

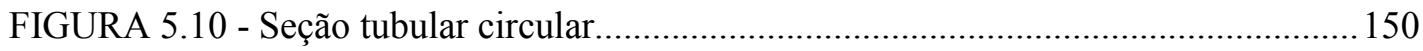

FIGURA 5.11 - Conectores fixados à alma em pilares mistos revestidos......................... 161

FIGURA 5.12 - Diagrama de interação momento-normal da seção mista............................167

FIGURA 5.13 - Distribuição de tensões correspondente ao diagrama de interação momento-normal da figura 5.12

FIGURA 5.14 - Procedimento de cálculo para a verificação da resistência para pilares mistos submetidos à flexão reta - EUROCODE 4 .

FIGURA 5.15 - Simplificação da norma BS 5400: Parte 5 (1979) para a curva de interação momento-normal.

FIGURA 6.1 - Curva tempo-temperatura de um edifício em situação de incêndio real.

FIGURA 6.2 - Comparação entre as curvas tempo-temperatura fornecidas pela ISO 834 (1975) e pela ASTM E119 (1988)..... 
FIGURA 6.3 - Diagrama tensão-deformação do aço $\left(\mathrm{f}_{\mathrm{y}}=235 \mathrm{MPa}\right)$ para temperaturas de $20^{\circ} \mathrm{C}$ a $600^{\circ} \mathrm{C}$

FIGURA 6.4 - Diagrama tensão-deformação do aço para temperaturas elevadas - EUROCODE 4

FIGURA 6.5 - Variação dos fatores de redução do módulo de elasticidade e da resistência ao escoamento do aço em função da temperatura - NBR 14323.

FIGURA 6.6 - Variação dos fatores de redução para a resistência característica do concreto com a elevação da temperatura - EUROCODE 4 / NBR 14323.

FIGURA 6.7 - Variação da temperatura ao longo da seção de vigas mistas EUROCODE 4: Parte 1.2 (1995).

FIGURA 6.8 - Diagrama força-escorregamento de conectores em temperatura elevada.

FIGURA 6.9 - Tensões na seção mista em temperatura elevada - interação completa.

FIGURA 6.10 - Tensões na seção mista em temperatura elevada - interação parcial........217

FIGURA 6.11 - Curva temperatura-tempo para alguns pontos da seção transversal de laje mista - HAMERLINK (1995)........................................................ 218

FIGURA 6.12 - Dimensões da seção transversal da laje mista...........................................220

FIGURA 6.13 - Posição da armadura na laje mista............................................................ 221

FIGURA 7.1 - Dimensões da seção da viga mista - exemplo 1..........................................220

FIGURA 7.2 - Efeito da retração sobre a viga mista do exemplo 1.....................................241

FIGURA 7.3 - Viga mista contínua - exemplo 2 …...........................................................242

FIGURA 7.4 - Tensões na seção mista - exemplo 2 2.......................................................247

FIGURA 7.5 - Momentos solicitantes de cálculo após a redistribuição.............................. 248

FIGURA 7.6 - Seção transversal do pilar misto preenchido - exemplo 3........................... 259

FIGURA 7.7 - Curva de interação momento-normal - exemplo 3. $\mathrm{N}_{\mathrm{sd}}=1.500 \mathrm{kN}$............265

FIGURA 7.8 - Curva de interação momento-normal - exemplo 3. $\mathrm{N}_{\mathrm{sd}}=2.500 \mathrm{kN}$...........266 


\section{LISTA DE TABELAS}

TABELA 2.1 - Resistência nominal de conectores tipo pino com cabeça em lajes maciças, segundo a BS 5950

TABELA 2.2 - Resistência nominal de conectores tipo perfil "U" laminado

e barra chata segundo a BS 5400 .

TABELA 2.3 - Comparação de resultados teóricos com resultados experimentais MALITE et al. (1998) 26

TABELA 3.1 - Comparação dos valores de largura efetiva para vigas mistas que se estendem apenas para um dos lados (vigas tipo "L") 41

TABELA 3.2 - Valores dos coeficientes de resistência segundo o EUROCODE 4. 59

TABELA 3.3 - Valores do coeficiente de homogeneização efetivo $\alpha_{e}$

TABELA 3.4 - Limites máximos da redistribuição de momentos fletores negativos em \% e em relação ao momento fletor inicial a ser reduzido. 79

TABELA 3.5 - Máxima tensão nas barras da armadura em função do diâmetro em barras de alta aderência.

TABELA 3.6 - Espaçamento máximo, em mm, entre barras de alta aderência. 92

TABELA 3.7 - Limites máximos da redistribuição de momentos fletores negativos em \% e em relação ao momento fletor inicial a ser reduzido.

TABELA 5.1 - Valores de $\eta_{10}$ e $\eta_{20}$ : EUROCODE 4.

TABELA 5.2 - Valores máximos de $\bar{\lambda}$ onde é permitido desprezar os efeitos da retração e da fluência, conforme o EUROCODE 4..................................................... 164

TABELA 5.3 - Valores das constantes $\mathrm{c}_{1}$ e $_{2}$ - BS 5400: Parte 5 (1979).

TABELA 6.1 - Valores tempo x temperatura - ASTM E119 (1988). Reproduzido de SILVA (1997)

TABELA 6.2 - Fator de massividade para elementos estruturais sem proteção 188

TABELA 6.3 - Fator de massividade para elementos estruturais com proteção. 189

TABELA 6.4 - Parâmetros que definem o diagrama tensão-deformação EUROCODE 4.

TABELA 6.5 - Fatores de redução para o aço - NBR 14323. 194

TABELA 6.6 - Fatores de redução para o concreto - EUROCODE 4 / NBR 14323.......... 196

TABELA 6.7 - Variação de temperatura na altura das lajes de concreto............................. 208

TABELA 6.8 - Espessura efetiva mínima da laje mista sem proteção térmica................... 219

TABELA 6.9 - Temperatura da armadura na laje mista. 221 
TABELA 6.10 - Dimensões mínimas da seção transversal de pilares mistos totalmente revestidos em função do tempo requerido de resistência ao incêndio

TABELA 6.11 - Recobrimento de concreto com função apenas de isolamento térmico.

TABELA 6.12 - Dimensões mínimas da seção transversal de pilares mistos parcialmente revestidos em função do tempo requerido de resistência ao incêndio......226

TABELA 6.13 - Dimensões mínimas da seção transversal de pilares mistos preenchidos em função do tempo requerido de resistência ao incêndio. 227

TABELA 6.14 - Valores do coeficiente $\mathrm{k}$ da equação (6.41) para pilares preenchidos......228

TABELA 7.1 - Comparação entre os resultados obtidos de diversas normas. .236

TABELA 7.2 - Momentos de inércia da seção homogeneizada............................................246

TABELA 7.3 - Resistência ao momento fletor (em kN.m)...............................................257 


\section{LISTA DE SÍMBOLOS}

$A_{a}-$ área da seção transversal do perfil de aço

$A_{c}$ - área da seção transversal de concreto

$a_{c}-$ parâmetro de contribuição do concreto (BS 5400)

$A_{p}$ - área efetiva da fôrma de aço (tracionada)

$A_{s}$ - área de seção transversal da armadura

$A_{t r}$ - área da seção homogeneizada

$b$ - largura efetiva da laje; largura do perfil tubular de aço

$b_{c}-$ largura da seção de concreto em pilares revestidos

$b_{f}-$ largura da mesa do perfil de aço

$C_{m}-$ fator de equivalência de carregamento (NBR 8800)

$c_{x}-$ recobrimento de concreto paralelo à direção $\mathrm{x}$

$c_{y}-$ recobrimento de concreto paralelo à direção $\mathrm{y}$

$d$ - altura do perfil de aço; diâmetro externo de tubos circulares de aço

$d_{p}-$ distância do centro de gravidade da fôrma à face superior de concreto

$E$ - módulo de elasticidade do aço

$e$ - distância do eixo de gravidade da fôrma de aço à sua extremidade inferior; excentricidade da força normal

$E_{\theta}$ - módulo de elasticidade do aço a uma temperatura $\theta_{a}$

$E_{c}-$ módulo de elasticidade do concreto

$E_{c, \theta}$ - módulo de elasticidade do concreto a uma temperatura $\theta_{c}$

$E_{m}-$ módulo de elasticidade modificado (AISC-LRFD)

$e_{p}-\quad$ distância da linha neutra plástica à extremidade inferior da fôrma de aço

$f_{c d}-$ resistência de cálculo à compressão do concreto

$f_{c k}-$ resistência característica do concreto à compressão

$f_{c k, \theta}$ - resistência característica à compressão do concreto de densidade normal a uma temperatura $\theta_{c}$

$f_{c k b, \theta}$-resistência característica à compressão do concreto de baixa densidade a uma temperatura $\theta_{c}$

$f_{m y}-$ resistência ao escoamento modificada (AISC-LRFD)

$f_{s d}-$ resistência de cálculo ao escoamento do aço da armadura

$f_{s y}$ - resistência ao escoamento do aço da armadura

$f_{y}-\quad$ resistência ao escoamento do aço do perfil 
$f_{y, \theta}-$ resistência ao escoamento dos aços laminados a quente a uma temperatura $\theta_{a}$

$f_{y d}-$ resistência de cálculo ao escoamento do aço do perfil

$f_{y o}-$ resistência ao escoamento dos aços trefilados a $20^{\circ} \mathrm{C}$

$f_{y o, \theta}-$ resistência ao escoamento dos aços trefilados a uma temperatura $\theta_{a}$

$f_{y p}-$ resistência ao escoamento do aço da fôrma

$g-\quad$ grau de conexão

$h$ - altura total da laje mista; largura do perfil de aço em pilares mistos

$h_{c}$ - altura da seção de concreto em pilares revestidos; altura de laje de concreto acima das nervuras da fôrma de aço

$h_{e f}-$ espessura efetiva mínima da laje mista sem proteção térmica

$h_{F}-$ altura nominal da nervura da fôrma

$h_{n}-$ distância do eixo de flexão à linha neutra

$h_{s}$ - distância entre a face inferior da laje e o eixo da armadura

$h_{w}-$ altura da alma do perfil de aço

$I_{1}$ - momento de inércia da seção mista "não fissurada"

$I_{2}$ - momento de inércia da seção mista "físsurada"

$I_{a}-$ momento de inércia da seção de aço

$I_{e f}-$ momento de inércia efetivo da seção homogeneizada (interação parcial)

$I_{t r}-$ momento de inércia da seção homogeneizada

$k_{c, \theta}$ - fator de redução para a resistência característica à compressão do concreto de densidade normal

$k_{c b, \theta}$ - fator de redução para a resistência característica à compressão do concreto de baixa densidade

$k_{E, \theta}$ - fator de redução para módulo de elasticidade de todos os aços

$K L$ - comprimento efetivo de flambagem

$k_{y, \theta}$ - fator de redução para o limite de escoamento dos aços laminados a quente

$k_{y o, \theta}$ - fator de redução para o limite de escoamento dos aços trefilados

$L-\quad$ vão do elemento misto

$L_{s}$ - vão de cisalhamento

$M_{b, R d}-$ momento resistente à flambagem lateral do elemento misto

$M_{c r}-$ momento fletor de flambagem elástica em temperatura ambiente (anexo D da NBR $8800)$

$M_{c r}$ - momento crítico elástico de flambagem lateral do elemento misto

$M_{f i, R d}$ - resistência ao momento fletor de uma barra fletida, em situação de incêndio

$M_{n}-$ momento nominal resistente do elemento misto (NBR 8800 e AISC-LRFD) 
$M_{p l}-$ momento de plastificação da seção transversal para o projeto em temperatura ambiente

$M_{p l, R d}$ - momento resistente de cálculo, admitindo a plastificação total da seção mista

$M_{r}-\quad$ momento fletor correspondente ao início do escoamento da seção transversal para o projeto em temperatura ambiente (anexo D da NBR 8800)

$M_{R d}$ - momento fletor resistente de cálculo do elemento misto

$M_{S d}$ - momento solicitante de cálculo

$M_{x, f i R d}$ - resistência de cálculo ao momento fletor, em situação de incêndio, em torno do eixo $\mathrm{x}$

$M_{x, f i, S d}$ - momento fletor solicitante de cálculo, em situação de incêndio, em torno do eixo x

$M_{x, p l, R d}$ - resistência de cálculo ao momento fletor em torno do eixo x da seção mista, considerando-se a plastificação total

$M_{x, S d}$ - momento fletor solicitante de cálculo em torno do eixo x da seção mista

$M_{y, f i, R d}$ - resistência de cálculo ao momento fletor, em situação de incêndio, em torno do eixo $\mathrm{y}$

$M_{y, f i, S d}$ - momento fletor solicitante de cálculo, em situação de incêndio, em torno do eixo y

$M_{y, p l, R d}$ - resistência de cálculo ao momento fletor em torno do eixo y da seção mista, considerando-se a plastificação total

$M_{y, S d}-$ momento fletor solicitante de cálculo em torno do eixo y da seção mista

$n$ - coeficiente de homogeneização

$N-\quad$ número de conectores de cisalhamento; força normal

$N_{c}-$ resistência de calculo à compressão axial da seção de concreto

$N_{e x}$ - normal de flambagem elástica por flexão no eixo x

$N_{e y}$ - normal de flambagem elástica por flexão no eixo y

$N_{f i, e x}$ - normal de flambagem elástica por flexão no eixo x, em situação de incêndio

$N_{f i, e y}$ - normal de flambagem elástica por flexão no eixo y, em situação de incêndio

$N_{f i, R d}$ - resistência de cálculo à tração ou à compressão axial em situação de incêndio

$N_{f i, S d}$ - força normal solicitante de cálculo em situação de incêndio

$N_{p l, R d}$ - resistência de cálculo à compressão axial da seção mista, considerando a plastificação total

$N_{R d}-$ resistência de cálculo à compressão axial da seção mista

$N_{S d}$ - força normal solicitante de cálculo

$Q_{f i n}$ - somatório das resistências nominais individuais dos conectores, em situação de incêndio

$q_{k}-$ resistência característica de um conector de cisalhamento 
$q_{n}-$ resistência nominal de um conector de cisalhamento

$Q_{n}$ - somatório das resistências nominais individuais dos conectores

$q_{R d}$ - resistência de cálculo de um conector de cisalhamento

$Q_{R d}$ - somatório das resistências de cálculo individuais dos conectores

$r$ - relação entre o menor e o maior momento de extremidade do pilar

$t-\quad$ espessura do perfil tubular

$t_{f}-\quad$ espessura da mesa do perfil de aço

$t_{w}$ - espessura da alma do perfil de aço

$u$ - perímetro do elemento estrutural exposto ao fogo

$V_{h}$ - resultante do fluxo de cisalhamento longitudinal

$V_{l, R d}$ - resistência de cálculo ao cisalhamento longitudinal

$V_{p, R d}-$ resistência de cálculo à punção

$V_{v, R d}$ - resistência de cálculo ao cisalhamento transversal

$W_{a}-$ módulo de resistência elástico da seção de aço

$W_{e f}$ - módulo de resistência elástico efetivo da seção homogeneizada (int. parcial)

$\left(W_{t r}\right)_{i}$ - módulo de resistência elástico da seção homogeneizada: fibra inferior

$\left(W_{t r}\right)_{s}$ - módulo de resistência elástico da seção homogeneizada: fibra superior

$Z_{p a}$ - módulo de resistência plástico da seção do perfil de aço

$Z_{p a n}$ - módulo de resistência plástico da seção do perfil de aço na região $2 \mathrm{~h}_{\mathrm{n}}$

$Z_{p c}$ - módulo de resistência plástico da seção de concreto, não fissurado

$Z_{p c n}$ - módulo de resistência plástico da seção de concreto na região $2 \mathrm{~h}_{\mathrm{n}}$

$Z_{p s}$ - módulo de resistência plástico da seção da armadura

$Z_{p s n}$ - módulo de resistência plástico da seção da armadura na região $2 \mathrm{~h}_{\mathrm{n}}$

$\bar{\lambda}$ - índice de esbeltez reduzido

$(E I)_{e}$ - produto de rigidez equivalente

$\bar{\lambda}_{\theta}-$ índice de esbeltez reduzido, a uma temperatura $\theta_{a}$

$\chi$ - fator de redução associado à flambagem (EUROCODE 3)

$\rho-\quad$ fator de redução associado à flambagem (NBR 8800)

$\delta$ - $\quad$ flecha total na viga mista; parâmetro de contribuição do aço

$\delta_{a}$ - flecha da viga de aço

$\phi_{a}-\quad$ coeficiente de resistência do aço do perfil (NBR 14323 e CAN/CSA-S16.1)

$\gamma_{a}-$ coeficiente de resistência do aço do perfil (EUROCODE 4) 
$\theta_{a}-$ temperatura do aço do perfil

$\gamma_{a p}-$ coeficiente de resistência do aço da fôrma

$\phi_{b}-$ coeficiente de resistência ao momento fletor: NBR 8800 e AISC-LRFD

$\phi_{b} M_{n}$ - resistência ao momento fletor do elemento misto (NBR 8800 e AISC-LRFD)

$\delta_{c}$ - flecha da viga mista considerando interação completa

$\gamma_{c}-$ peso específico do concreto; coeficiente de resistência do concreto (EUROCODE 4)

$\phi_{c}-$ coeficiente de resistência do concreto ( NBR 14323 e CAN/CSA-S16.1)

$\theta_{c}-$ temperatura do concreto

$\phi_{c} N_{n}$ - resistência de cálculo à compressão do elemento misto (AISC-LRFD)

$\phi_{f, i}-$ temperatura da mesa inferior do perfil de aço

$\phi_{f, s}-$ temperatura da mesa superior do perfil de aço

$\rho_{f i}-$ fator de redução da resistência à compressão em situação de incêndio

$\eta_{f i}-$ nível de carga

$\phi_{f i, a}$ - coeficiente de resistência do aço em situação de incêndio

$\phi_{f i c}$ - coeficiente de resistência do concreto em situação de incêndio

$\chi_{L T}-$ fator de redução da resistência associado à flambagem lateral (EUROCODE 3)

$\lambda_{m}-$ índice de esbeltez reduzido modificado (AISC-LRFD)

$\lambda_{p, f i}-$ parâmetro de esbeltez correspondente à plastificação, em situação de incêndio

$\lambda_{r, f i}-$ parâmetro de esbeltez correspondente ao limite de proporcionalidade, em situação de incêndio

$\phi_{s}-\quad$ coeficiente de resistência do aço da armadura ( NBR 14323)

$\gamma_{s}-$ coeficiente de resistência do aço da armadura (EUROCODE 4)

$\theta_{s}-$ temperatura do aço da armadura

$\gamma_{v}-$ coeficiente de resistência do conector (EUROCODE 4)

$\phi_{w}-$ temperatura da alma do perfil de aço 


\title{
RESUMO
}

\begin{abstract}
ALVA, G.M.S. (2000). Sobre o projeto de edificios em estrutura mista açoconcreto. São Carlos, 2000. 277p. Dissertação (Mestrado) - Escola de Engenharia de São Carlos, Universidade de São Paulo.
\end{abstract}

Este trabalho apresenta uma abordagem abrangente das estruturas mistas açoconcreto, com ênfase em edifícios, e dos principais elementos que compõem esse sistema: as vigas mistas, simplesmente apoiadas e contínuas, as lajes mistas e os pilares mistos. São abordados os aspectos construtivos, o comportamento estrutural e os procedimentos para dimensionamento recomendados pelas principais normas aplicáveis, enfatizando a norma norte-americana do AISC e o EUROCODE 4. O projeto em situação de incêndio também é analisado, considerando o comportamento e o dimensionamento de elementos mistos frente à ação do fogo. No final, são desenvolvidos exemplos de dimensionamento, onde procura-se comparar e discutir os resultados obtidos pelas principais normas.

Palavras-chave: estruturas mistas aço-concreto, vigas mistas, lajes mistas, pilares mistos, incêndio 


\section{ABSTRACT}

ALVA, G.M.S. (2000). On the design of buildings with composite structures. São Carlos, 2000. 277p. Dissertação (Mestrado) - Escola de Engenharia de São Carlos, Universidade de São Paulo.

This study consists of a broad analysis of composite structures, with particular emphasis on buildings, and the principal elements that make up this system, i.e., continuous and simply supported composite beams, composite slabs and composite columns. Several aspects of construction are broached, as well as structural behavior and the procedures for design recommended by the main codes, mainly the American AISC and the EUROCODE 4 codes. Fire design is also analyzed, considering the behavior and design of composite elements under fire conditions. The study concludes with some examples of design, comparing and discussing the results achieved by the principal codes.

Keywords: composite structures, composite beams, composite slabs, composite columns, fire. 


\subsection{CONSIDERAÇÕES INICIAIS}

O desenvolvimento econômico, técnico e científico fez surgir diversos sistemas estruturais e construtivos, entre os quais estão os sistemas formados por elementos mistos aço-concreto, cuja combinação de perfis de aço e concreto visa aproveitar as vantagens de cada material, tanto em termos estruturais e como construtivos.

A história da construção mista está intimamente ligada ao desenvolvimento do concreto armado e das estruturas em aço. Nas construções mistas, o concreto foi primeiramente usado, no início do século, como material de revestimento, protegendo os perfis de aço contra o fogo e a corrosão. Embora o concreto tivesse uma participação em termos estruturais, sua contribuição na resistência era ignorada nos cálculos. Lajes maciças com vigas de aço revestidas foram bastante usadas nas décadas de 40 e 50, com alguma interação permitida para esta condição. O desenvolvimento dos conectores de cisalhamento contribuiu significativamente para acelerar os avanços associados às vigas mistas. Hoje, vigas e treliças mistas com conectores de cisalhamento e lajes com fôrma de aço incorporada são intensamente usadas em edifícios de múltiplos pavimentos.

Avanços posteriores do concreto armado destinados aos edifícios altos determinaram o cenário da combinação do sistema aço-concreto. Neste processo, o uso do concreto desempenhando o papel de paredes resistentes à força cortante ("shear walls") ou o de pilares mistos tubulares foram reconhecidos como sendo elementos estruturais eficientes para resistir às forças devidas ao vento, aumentando a rigidez lateral da estrutura, quando comparados à estrutura de aço correspondente. 
$\mathrm{O}$ uso desses elementos em estruturas usuais do tipo pórtico em aço ofereceu vantagens em termos de economia e de rapidez de execução. O objetivo desta combinação foi conciliar a rigidez do concreto na resistência aos carregamentos laterais com o menor peso do material aço e sua capacidade de vencer vãos maiores em estruturas do tipo pórtico.

No Brasil, as primeiras construções mistas restringiram-se a alguns edifícios e pequenas pontes construídas entre os anos de 1950 e 1960. MALITE (1990) ressalva que, com o aumento da produção de aço estrutural no Brasil e com a busca de novas soluções arquitetônicas e estruturais, foram construídos vários edifícios no sistema misto nos últimos anos. As estruturas mistas foram normatizadas pela primeira vez em 1986 pela NBR-8800: "Projeto e Execução de Estruturas de Aço de Edifícios", a qual aborda o dimensionamento e execução somente dos elementos mistos submetidos à flexão (vigas mistas).

Comparando-se com as condições correntes do concreto armado, a construção em sistema misto aço-concreto é competitiva para estruturas de vãos médios a elevados, caracterizando-se pela rapidez de execução e pela significativa redução do peso total da estrutura, propiciando assim fundações mais econômicas.

A proteção contra o fogo é um fator que, por afetar o custo final da estrutura, influencia a escolha entre as estruturas de concreto, mistas e de aço. $\mathrm{O}$ preenchimento ou o revestimento de perfis de aço com concreto, constituindo elementos mistos, podem ser soluções econômicas quando é necessária a proteção contra o fogo e contra a corrosão. No Brasil, a norma NBR 14323: "Dimensionamento de estruturas de aço em situação de incêndio", aprovada em 1999, aborda o dimensionamento de elementos estruturais mistos (vigas, lajes e pilares) em situação de incêndio e também em temperatura ambiente, no caso das lajes e pilares mistos.

\subsection{OBJETIVOS}

Este trabalho teve por objetivo principal a revisão bibliográfica abrangente sobre as estruturas mistas aço-concreto, com ênfase em edifícios, abordando os sistemas estruturais, o dimensionamento e os aspectos construtivos mais relevantes 
dos elementos que compõem o sistema estrutural misto, ou seja, as vigas mistas simplesmente apoiadas e contínuas, as lajes mistas e os pilares mistos. Tratou-se também do dimensionamento em situação de incêndio. Por fim, desenvolveram-se exemplos de dimensionamento com base nas principais normas aplicáveis, discutindo as particularidades dos requisitos destas normas.

\subsection{JUSTIFICATIVAS}

As estruturas mistas aço-concreto constituem uma linha de pesquisa estabelecida pela área de Estruturas Metálicas, iniciada com o Mestrado e Doutorado do Prof. Maximiliano Malite, concluídos em 1990 e 1993, respectivamente, o qual abordou o projeto das vigas mistas.

A definição desta linha de pesquisa pode ser atribuída à crescente demanda das estruturas metálicas na construção de edifícios de múltiplos pavimentos no Brasil, a partir da década de 80, competindo, ainda que de forma modesta, com a solução em concreto armado moldado no local. Carece, entretanto, de pesquisas e trabalhos adequados à realidade brasileira e que contribuíram para a viabilidade técnica e econômica do sistema, consagrado em vários países, mas que ainda não se desenvolveu amplamente na construção civil nacional.

Dando sequência a esta linha de pesquisa, em 1998 a Eng. Luciana Figueiredo concluiu o Mestrado abordando os aspectos estruturais e construtivos dos pilares mistos e, em 1999, o Eng. Gelafito Klinsky analisou as estruturas mistas dos tabuleiros de pontes.

Neste contexto, este trabalho procurou contribuir no sentido de desenvolver uma revisão bibliográfica mais abrangente sobre as estruturas mistas, abordando o sistema estrutural, os aspectos construtivos e os principais elementos componentes: lajes, vigas e pilares dos edifícios de múltiplos pavimentos (edifícios de "pequena altura"). 


\subsection{SISTEMAS ESTRUTURAIS}

\section{GENERALIDADES}

As estruturas dos edifícios têm como função primária receber, em planos horizontais, as ações gravitacionais e transmiti-las às fundações. Devem cumprir também a função de transmitir à base solicitações horizontais, como as provenientes da ação do vento.

Os sistemas estruturais, portanto, consistem na reunião de elementos estruturais de concreto, de aço, mistos e outros, de maneira que estes trabalhem de forma conjunta para resistir às ações atuantes no edifício e garantir sua estabilidade.

CORRÊA (1991) lembra que a escolha de um sistema estrutural adequado para um edifício não é uma questão simples, pois existem diversos fatores importantes a serem considerados, tais como conciliar o sistema estrutural com a funcionalidade do edifício, eleger os materiais a serem utilizados e também escolher e arranjar os elementos estruturais de maneira eficiente. Da mesma forma, aplica-se aos sistemas que utilizam elementos mistos, devendo-se explorar as propriedades de cada material, de modo que a interação entre os componentes estruturais de aço e de concreto possa trazer eficiência tanto em sentido estrutural como em termos econômicos

Para a melhor compreensão do comportamento dos edifícios de múltiplos andares, o sistema estrutural pode ser decomposto em dois sistemas principais: os sistemas horizontais e os sistemas verticais. Estes sistemas são apresentados a seguir.

\section{SISTEMAS HORIZONTAIS}

Os sistemas horizontais, constituídos pelas vigas, lajes e eventuais contraventamentos, têm como funções a transmissão das ações gravitacionais aos pilares ou paredes estruturais e a distribuição das ações do vento aos diversos sistemas verticais, comportando-se como diafragmas. Neste sistema, o comportamento é predominantemente de flexão. 
SÁLES (1995) ressalva que, para cumprirem as funções a que estão destinados, os sistemas horizontais devem possuir uma rigidez suficiente para trabalharem como diafragmas. Quando são executados em laje de concreto, fundido no local, possuem uma rigidez suficiente para isso. Entretanto, quando são executados em elementos pré-fabricados, nem sempre essa rigidez é alcançada, devendo-se fazer uma das seguintes opções: projetar um contraventamento ao nível das vigas ou procurar formar um sistema misto com a laje de concreto e a viga de aço.

A utilização do sistema misto como sistema horizontal traz algumas vantagens. A primeira é a economia de material e a facilidade de execução. Neste caso, a ligação do elemento de aço à laje de concreto é feita por conectores de cisalhamento de diversos tipos, tais como pino com cabeça, perfis laminados, perfis formados a frio, barras redondas, etc. Uma outra vantagem que o sistema misto oferece é a possibilidade de se considerar as vigas de aço contidas lateralmente, eliminando, portanto, o estado limite de flambagem lateral com torção, uma vez endurecido o concreto. A figura 1.1 ilustra algumas alternativas do sistema misto aplicado aos sistemas horizontais.
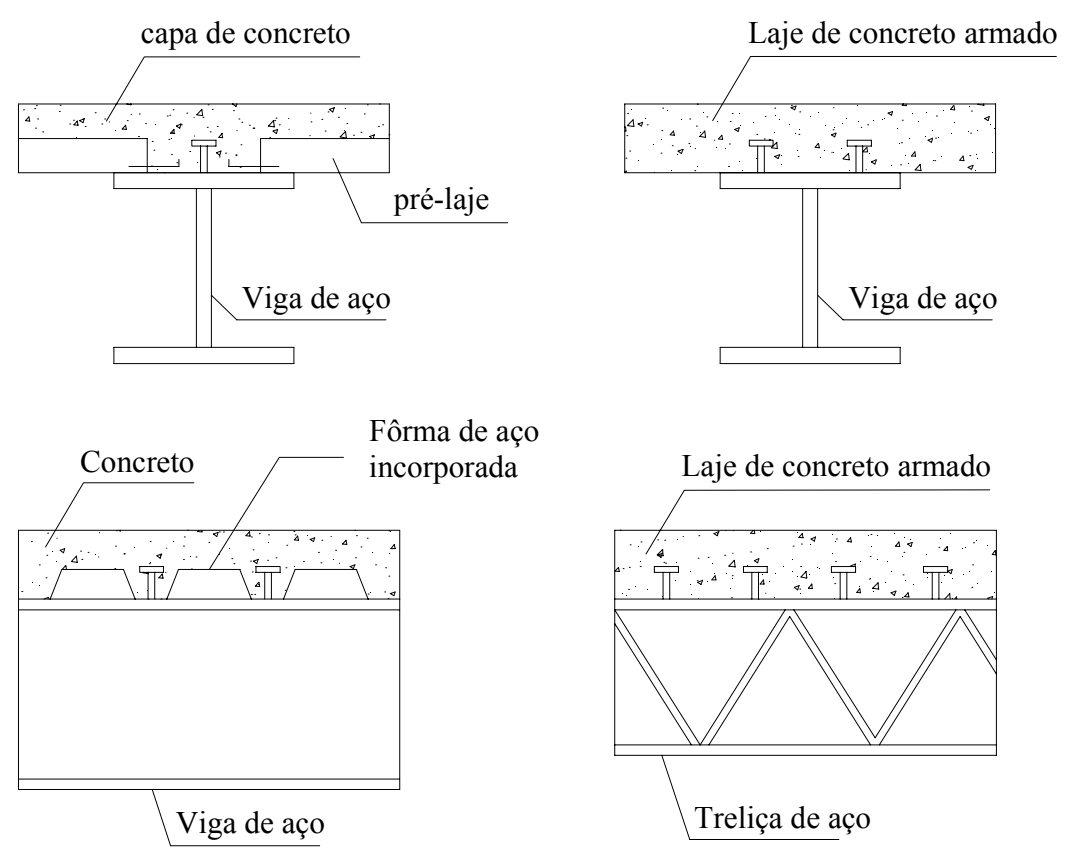

FIGURA 1.1: Aplicação do sistema misto em sistemas estruturais horizontais 
O sistema de lajes com fôrmas de aço incorporadas, caracterizando o sistema de lajes mistas, também fornece vantagens, pois além de contribuir como armadura positiva, dispensa o escoramento e funciona como diafragma horizontal. A figura 1.2 mostra uma aplicação do sistema de lajes mistas em edifícios. A figura 1.3 ilustra um exemplo de um sistema de piso executado por elementos pré-fabricados.
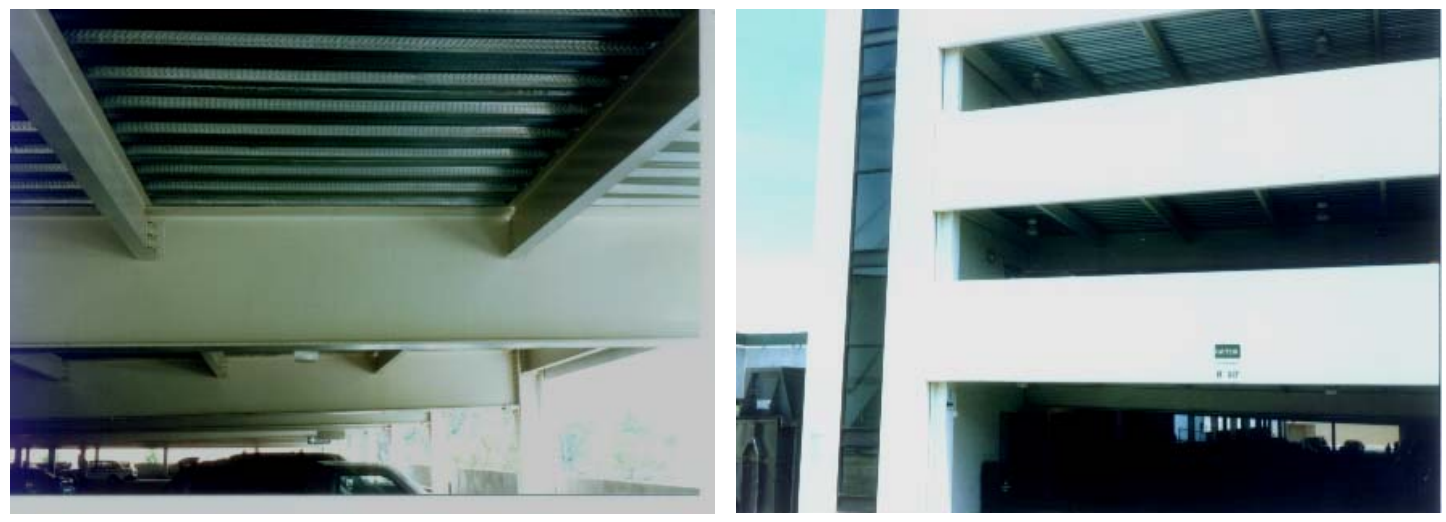

FIGURA 1.2: Exemplo de aplicação do sistema de lajes mistas em edifício garagem
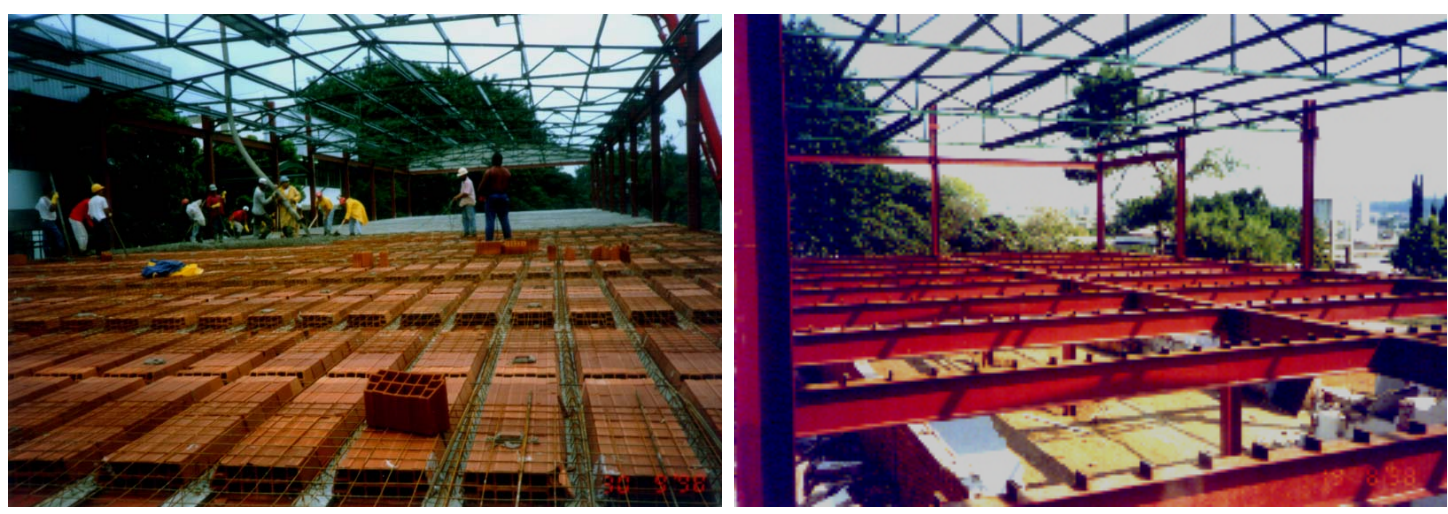

FIGURA 1.3: Exemplo de aplicação de lajes nervuradas pré-fabricadas em piso de edificio

\section{SISTEMAS VERTICAIS}

Os sistemas verticais têm como funções básicas a transmissão das ações gravitacionais e horizontais às fundações, além de conferirem estabilidade global ao edifício e de resistirem às ações do vento. Este sistema pode ser constituído por pilares, pórticos, paredes, núcleos e contraventamentos. A partir da combinação 
desses elementos, existem diversos tipos de sistemas verticais, aplicáveis tanto a edifícios de pequena altura quanto a edifícios altos. A figura 1.4 ilustra algumas dessas combinações.
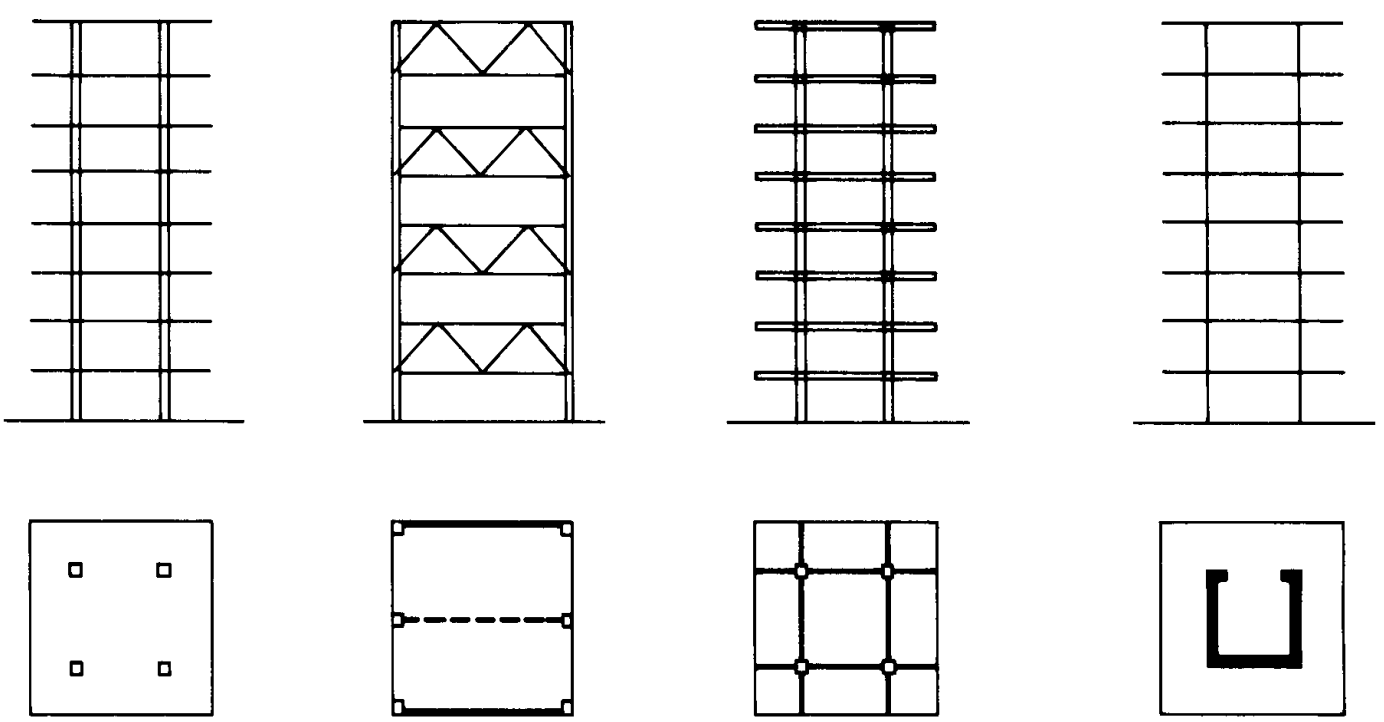

PILARES
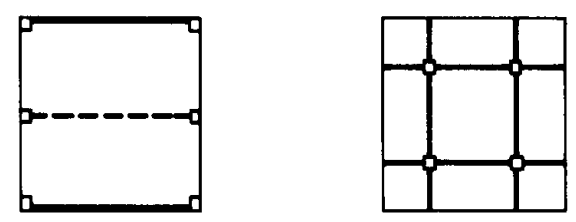

TRELICA INTER PAVIMENTO

PÓRTICO

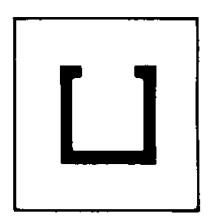

NÚCLEO
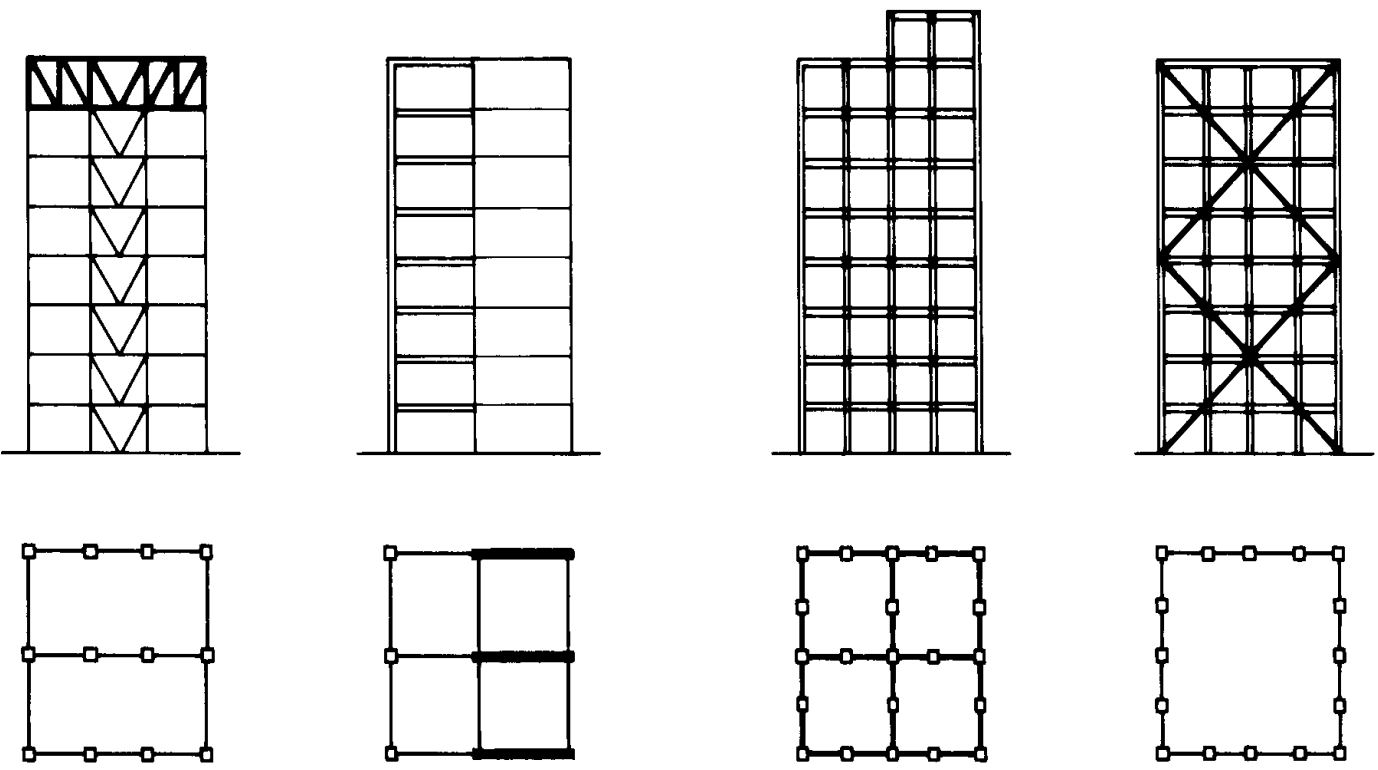

TRELICA PASSANTE

PÓRTICOS E PAREDES ASSOCIADOS

FIGURA 1.4: Alguns tipos de sistemas verticais. CORREA (1991) 
Embora não exista unanimidade entre os autores sobre a denominação dos sistemas verticais, pode-se subdividi-los em função das suas características estruturais mais importantes em:

- Sistemas em pórticos

- Sistemas em treliças

- Sistemas com núcleo rígido

- Sistemas tubulares

Esses sistemas estruturais podem ser combinados ou não, de forma a atender às exigências específicas do projeto. Com a multiplicidade dos sistemas disponíveis, o engenheiro pode propor uma solução ótima para cada tipo de edifício, delimitado pela sua altura, arquitetura ou outras condições específicas do projeto. Para edifícios de "pequena altura", em geral, são empregados os três primeiros sistemas já mencionados, ou combinações entre eles, resultando:

- Pórticos e Treliças

- Pórticos e Núcleo

- Treliças e Núcleo

\section{Sistemas em Pórticos}

O sistema em pórticos podem ser entendidos como a associação de pórticos planos, os quais são constituídos por vigas e pilares conectados rigidamente. Portanto, a estabilidade global é conferida por pórticos planos dispostos nas duas direções, constituindo um pórtico tridimensional.

SÁLES (1995) salienta que esse sistema apresenta diversas qualidades que o torna uma solução estrutural clássica em estruturas de aço. Dentre essas qualidades, está sua simplicidade de formação, permitindo a decomposição do seu comportamento tridimensional em diversos sistemas planos que o formam, possibilitando uma análise mais rápida sem prejuízo da coerência ou da exatidão. Além da simplicidade dessa formação, nos sistemas em pórtico de aço pode-se 
explorar a leveza dos seus elementos, evidenciada pela pequena relação altura/vão das vigas e dos pilares.

Do ponto de vista arquitetônico, o sistema em pórticos apresenta vantagens, pois não é necessária a inclusão de contraventamentos para garantir a estabilidade lateral, evitando a obstrução de aberturas e fachadas.

A figura 1.5 exemplifica a aplicação do sistema em pórticos.

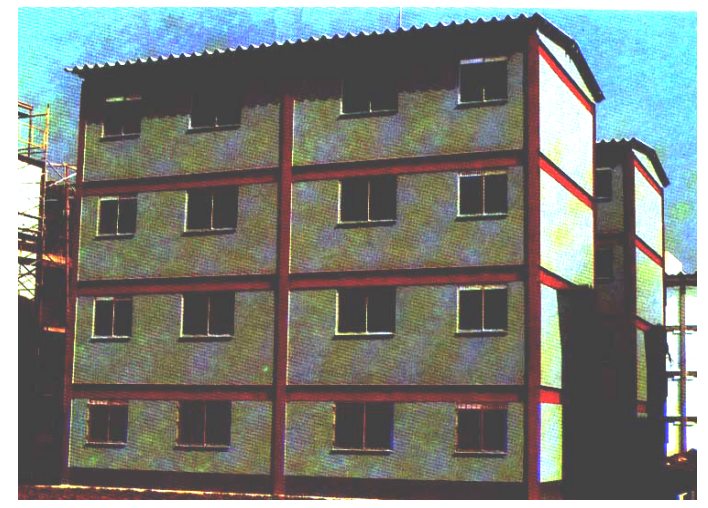

a) Edifício COHAB Heliópolis - São Paulo Fonte: DIAS (1993)

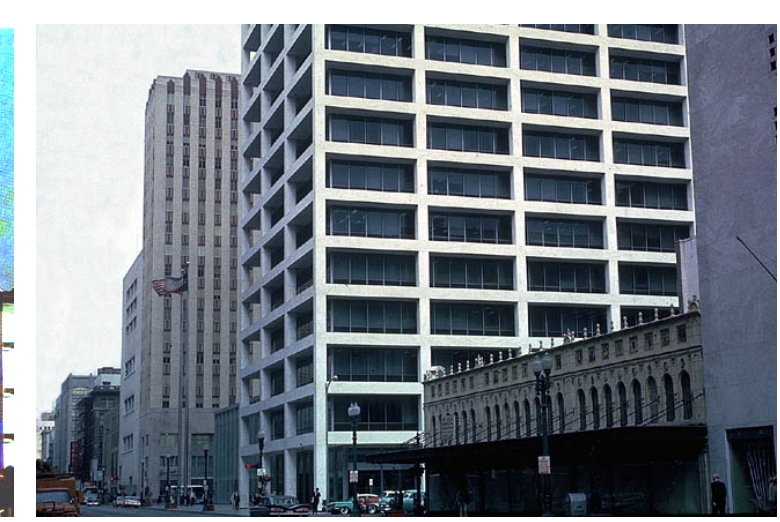

b) First City National Bank Building - Texas, Estados Unidos

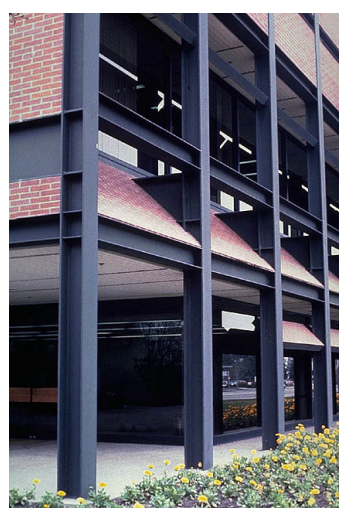

c) Edifício de 6 pavimentos -

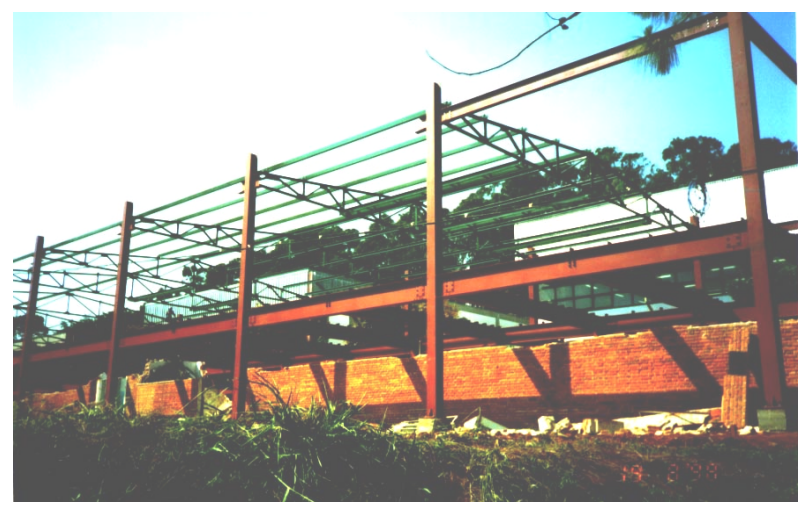

d) Edifício do Serviço de Biblioteca da EESC - São Carlos

Califórnia, Estados Unidos

FIGURA 1.5: Exemplo de aplicação do sistema em pórtico

\footnotetext{
${ }^{1}$ Godden Structural Engineering Slide Library (1999).

http://www.mip.berkeley.edu/eqiis_img/6257_3021_0647/IMG0068.jpg

${ }^{2}$ Godden Structural Engineering Slide Library (1990) http://www.mip.berkeley.edu/eqiis_img/ 6257_3021_0647/IMG0064.jpg
} 


\section{Sistemas Treliçados}

A utilização de treliças como responsáveis pela estabilidade do edifício frente às ações horizontais consiste em uma alternativa econômica, pois com um pequeno acréscimo do peso da estrutura, pode-se eliminar a necessidade de se empregar ligações rígidas entre vigas e pilares.

A maior desvantagem do contraventamento diagonal é que este pode interferir no planejamento interno, inviabilizando a circulação e a ocupação dos pisos. Por isso, o contraventamento inclinado é, com freqüência, utilizado internamente, escondendo-se as diagonais de contraventamento com o fechamento da fachada do edifício.

A figura 1.6 apresenta um exemplo de disposição de treliças em edifícios de múltiplos andares.

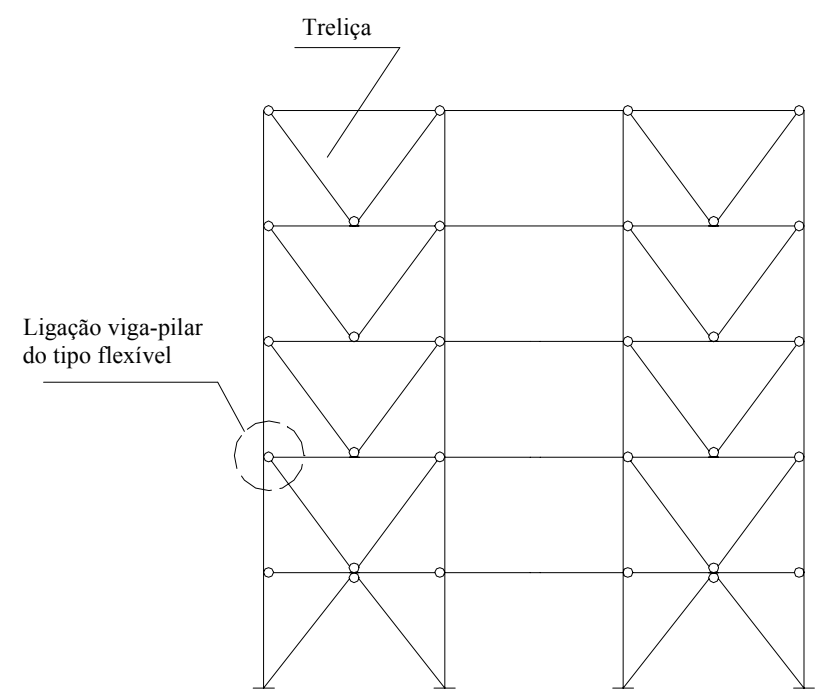

FIGURA 1.6: Exemplo de sistema de treliças em edifício de múltiplos andares

A figura 1.7 ilustra um exemplo de edifício onde as ligações viga-pilar são todas ligações flexíveis, estando a estabilidade da estrutura assegurada por vários contraventamentos em " $\mathrm{X}$ " nas duas direções. 

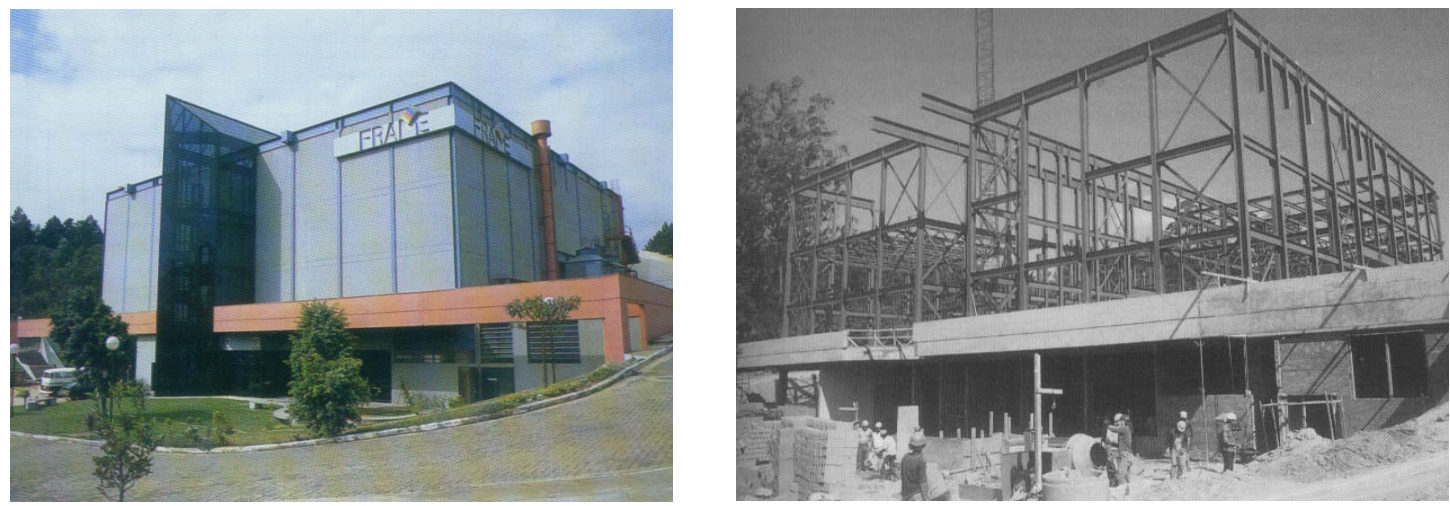

FIGURA 1.7: Edifício Cinevídeo Frame - Cotia/SP

Fonte: DIAS (1993)

A figura 1.8 ilustra um exemplo de edifício cujo contraventamento em "V" forma treliças nas duas direções.
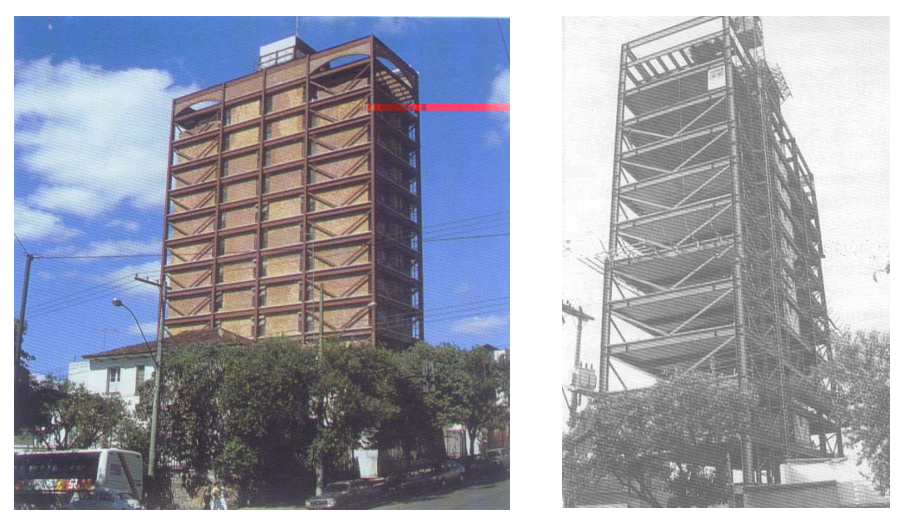

FIGURA 1.8: Edificio Saraiva Marinho - Belo Horizonte/MG

Fonte: DIAS (1993)

\section{Sistemas com núcleo rígido}

Neste sistema, admite-se que o núcleo estrutural seja responsável por resistir a todos os efeitos das ações horizontais e, o restante da estrutura, ao redor do núcleo, por resistir unicamente às ações gravitacionais. O núcleo é constituído pela associação de paredes em concreto armado ou mistas aço-concreto. As ligações existentes entre as vigas de aço e as paredes do núcleo não transferem momentos fletores e, portanto, constituem ligações flexíveis. 
O núcleo de concreto também é responsável por toda a rigidez à torção e à flexão do edifício como um todo. O sistema estrutural de aço apenas é responsável por resistir e transmitir os esforços das ações gravitacionais aos pilares e às paredes do núcleo.

Segundo IYENGAR \& IQBAL (1986), o sistema com núcleo central pode ser vantajoso economicamente em edifícios de até 45 pavimentos. Para edifícios mais altos, este sistema geralmente deixa de trazer vantagens, pois o núcleo de concreto perde a eficiência em absorver as ações horizontais. A figura 1.9 ilustra um esquema típico desse tipo de sistema estrutural. A figura 1.10 mostra um exemplo de aplicação desse sistema.

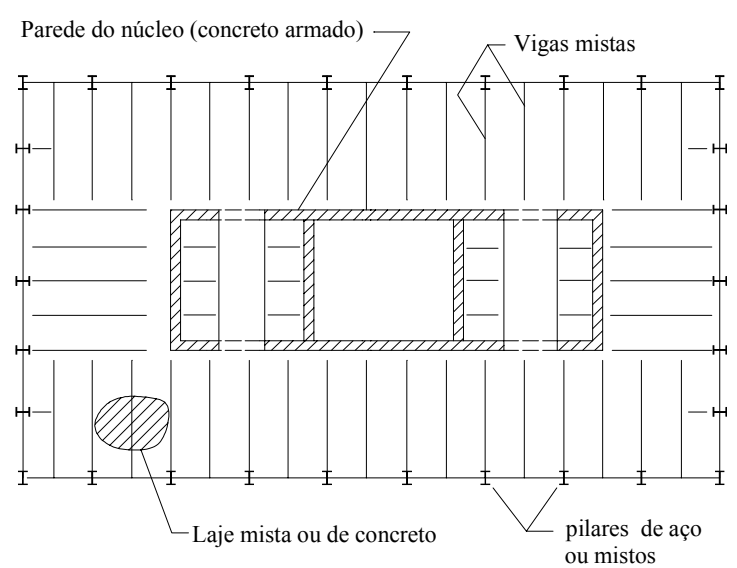

Planta

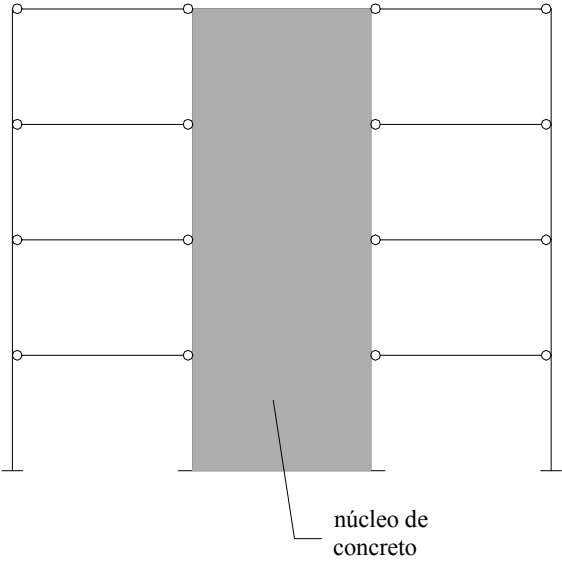

Elevação

FIGURA 1.9: Esquema típico do sistema com núcleo central 

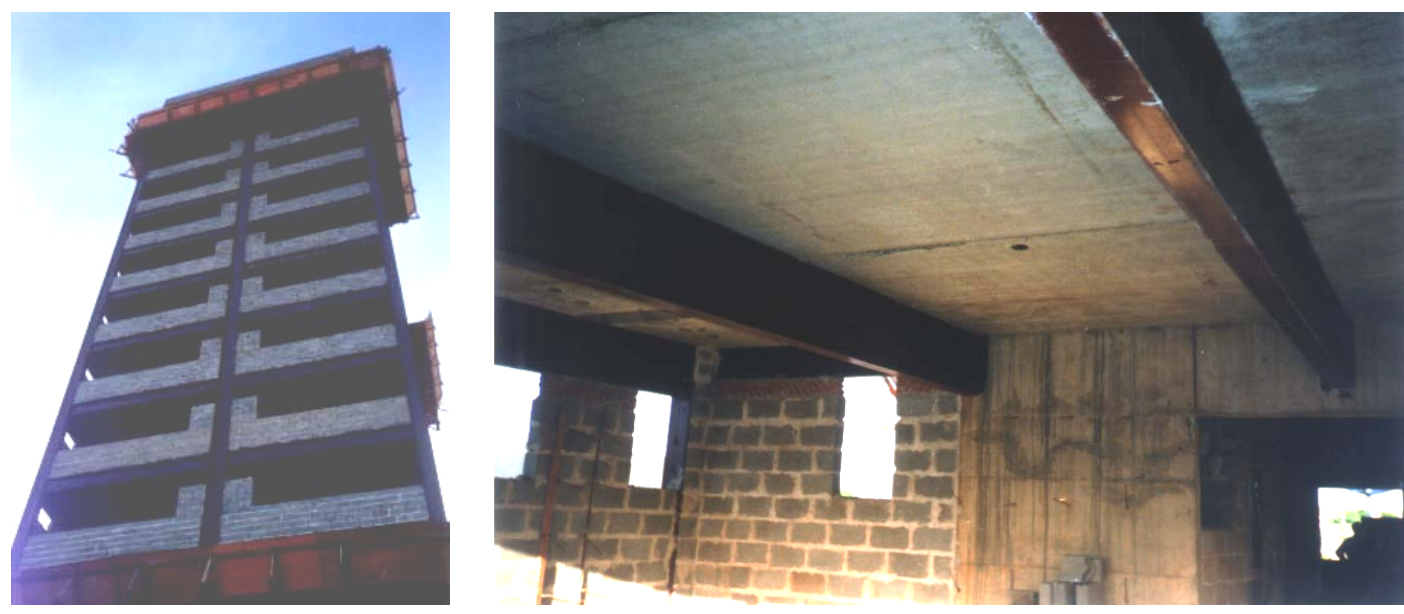

FIGURA 1.10: Exemplo de aplicação do sistema com núcleo estrutural de concreto em edificio de múltiplos andares - Ribeirão Preto/SP

SÁLES (1995) acrescenta que os sistemas com núcleo de concreto podem oferecer uma redução no consumo de aço, devido ao aumento da rigidez pela incorporação das paredes de concreto. Entretanto, o consumo de concreto estrutural é maior, o que acarreta maiores solicitações às fundações, devido ao alto peso próprio do concreto das paredes que formam os núcleos estruturais.

Existem outras duas considerações importantes a serem analisadas quanto ao emprego do sistema com núcleo de concreto. A primeira é a falta de garantia de compatibilização das velocidades de execução das duas modalidades construtivas. A outra é a precisão de fabricação das duas tecnologias: nas estruturas de aço, é possível obter precisão da ordem do milímetro, enquanto que nas estruturas de concreto, pode-se dizer que essa precisão não é mais baixa que a ordem do centímetro.

Com relação à utilização de elementos estruturais mistos, os edifícios com núcleos rígidos permitem a possibilidade de se empregar apenas ligações flexíveis, contribuindo para a eficiência do sistema misto. Essa eficiência aplica-se principalmente às vigas mistas, as quais solicitadas apenas por momentos fletores positivos, permitem que o concreto trabalhe apenas à compressão. 


\section{Sistemas tubulares}

Os sistemas tubulares são formados, em geral, pela disposição de pilares no exterior do edifício, formando pórticos com as vigas a elas conectadas, por meio de ligações rígidas, podendo também constituir paredes treliçadas (ver figura 1.4).

Os sistemas tubulares podem ser entendidos como uma extensão dos sistemas em pórticos, de modo que se aumenta a rigidez do edifício diminuindo-se o espaçamento entre pilares e aumentando-se a altura dos elementos estruturais. Desse modo, o pequeno espaçamento entre pilares caracteriza os sistemas tubulares.

$\mathrm{O}$ arranjo dos pilares e das vigas confere à estrutura uma grande rigidez à torção, sendo esta uma outra característica dos sistemas tubulares.

A rigidez do edifício pode ser aumentada empregando-se uma estrutura tubular interna, ou um sistema de células tubulares interligadas, formando um sistema multicelular de grande rigidez.

Os sistemas tubulares têm aplicações em edifícios de "grande altura". A figura 1.11 a) mostra um exemplo de aplicação do sistema tubular com paredes tipo pórtico e a figura $1.11 \mathrm{~b}$ ), um exemplo do sistema tubular com paredes treliçadas.

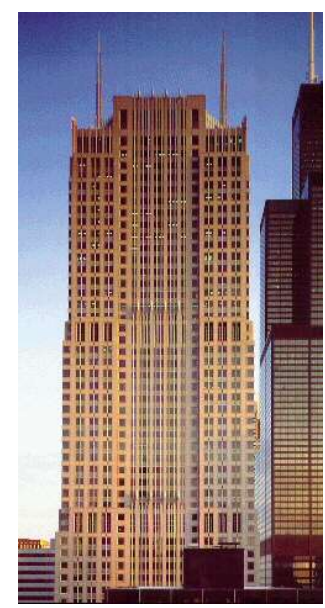

a) Edificio AT \& T Corporate CenterChicago, Estados Unidos

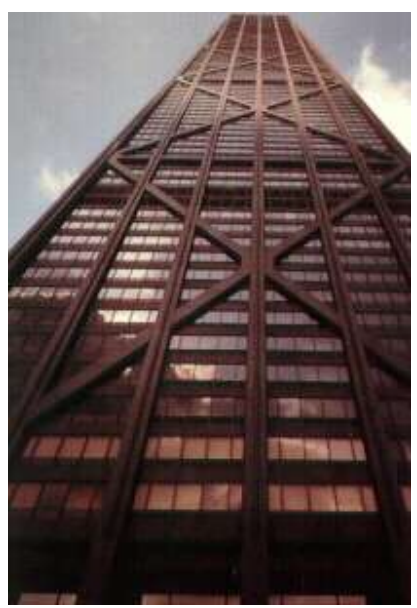

b) Edificio John Hancock CenterChicago, Estados Unidos ${ }^{3}$

FIGURA 1.11: Exemplo de aplicação dos sistemas tubulares

\footnotetext{
${ }^{3}$ World's Talling Buildings (1999). http://www.high-rises.co.uk/worlds_tallest.html
} 
A figura 1.12 ilustra um exemplo de edifício no qual foi utilizado o sistema tubular juntamente com o núcleo estrutural de concreto.

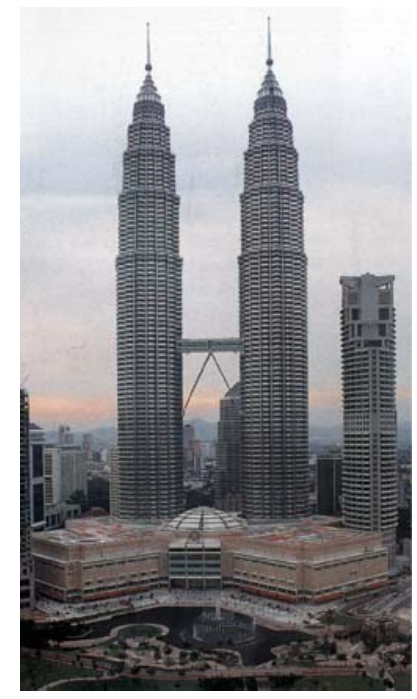

FIGURA 1.12: Edifício Petronas Twin Tower Kuala Lumpur, Malásid 4

\footnotetext{
${ }^{4}$ Petronas Twin Towers (1997). http://members.tripod.com/ mcleon/tower1.htm
} 


\section{CONECTORES DE CISALHAMENTO}

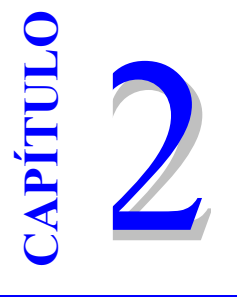

\subsection{COMPORTAMENTO ESTRUTURAL}

Realizam a ligação entre o elemento de aço e a laje de concreto. Cumprem a função de absorver os esforços de cisalhamento nas duas direções e de impedir o afastamento vertical entre a laje e viga de aço.

Os conectores classificam-se em flexíveis e rígidos. O conceito de rigidez, neste caso, está relacionado com a capacidade de restrição ao escorregamento imposta pela ligação viga de aço/laje de concreto. Os conectores do tipo pino com cabeça são os mais utilizados dentre os flexíveis, na maioria dos países, devido à facilidade de fabricação utilizando o processo de soldagem semi-automático. Além disso, apresentam a mesma resistência em todas direções. As figuras 2.1 e 2.2 ilustram alguns dos tipos de conectores flexíveis e rígidos mais utilizados. Os conectores em a), b), d) e e) da figura 2.1 classificam-se como flexíveis; o conector em c) da figura 2.1 classifica-se como rígido.

A característica estrutural mais importante dos conectores de cisalhamento é a relação existente entre a força $F$ transmitida pelo conector e o escorregamento relativo $s$ na interface aço-concreto, determinando seu comportamento "dúctil". O diagrama típico de $F x s$ é ilustrado na figura 2.3.

A flexibilidade dos conectores, portanto, garante que o colapso de uma viga mista, quando se dá a ruptura da ligação aço-concreto, seja do tipo "dúctil”.

OEHLERS \& COUGHLAN (1986) apresentaram, a partir de resultados experimentais, o diagrama força $\mathrm{x}$ escorregamento para conectores do tipo pino com cabeça embutidos em laje maciças. Pela figura 2.4, nota-se a existência de um patamar "dúctill", representado pelo trecho C-D, até que se atinja o escorregamento 
$S_{u}$. Para valores de escorregamento maiores que $S_{u}$, a força no conector sofre um decréscimo, atingindo um valor de $0,95 P_{u}$ na ruptura, quando $s=S_{r}$. Os valores $S_{u}$ e $S_{r}$ são obtidos através da análise estatística desses resultados, e dependem do diâmetro do corpo do conector e da resistência característica do concreto à compressão, conforme OEHLERS \& SVED (1995).

MALITE (1993) realizou ensaios padronizados do tipo push-out, em modelos semelhantes aos apresentados na norma inglesa BS 5400 (1979) e ECCS (1981), para a avaliação da resistência última e do comportamento força-escorregamento de alguns tipos de conectores em chapa dobrada (formados a frio). Foram analisados três tipos de conectores: cantoneira simples, cantoneira enrijecida e perfil " $U$ ", em duas espessuras de chapa $(2,66 \mathrm{~mm}$ e $4,76 \mathrm{~mm})$. Dois modos de ruptura foram identificados no ensaio. Nos conectores de chapa mais fina $(2,66 \mathrm{~mm})$, observou-se a ruptura do aço do conector junto à solda. Nos conectores de chapa mais grossa, observou-se a ruptura do concreto por esmagamento resultante da rotação excessiva do conector. Em ambos os tipos de ruptura, notou-se que os conectores em cantoneira mantiveram a sua forma geométrica inicial, ocorrendo apenas uma rotação do conector junto à solda de ligação com o perfil de aço. Os conectores constituídos por cantoneira enrijecida apresentaram comportamento bastante semelhante aos de cantoneira simples, mostrando que, neste caso, o lábio enrijecedor não altera o comportamento força-escorregamento, nem a resistência última do conector. Os conectores em perfil "U" não apresentaram diferenças significativas no comportamento força-escorregamento em relação aos conectores em cantoneira com mesma espessura, embora apresentassem altura maior que as cantoneiras. Isto demonstra que a espessura de chapa do conector é a variável que mais influenciou a resistência da conexão. 

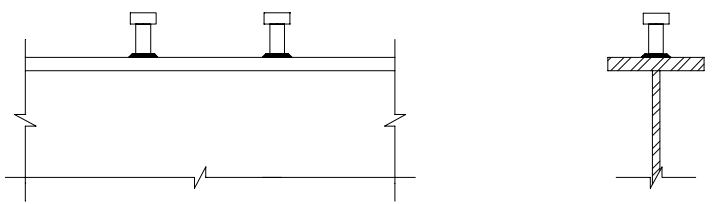

a) Pino com cabeça (STUD)
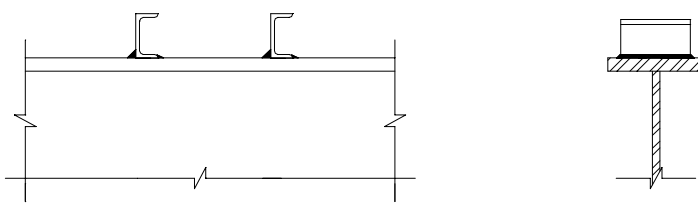

b) Perfil "U" laminado
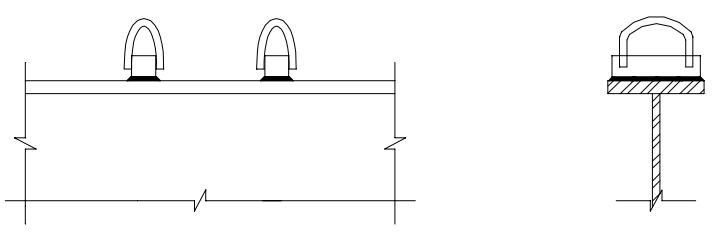

c) Barra com alça
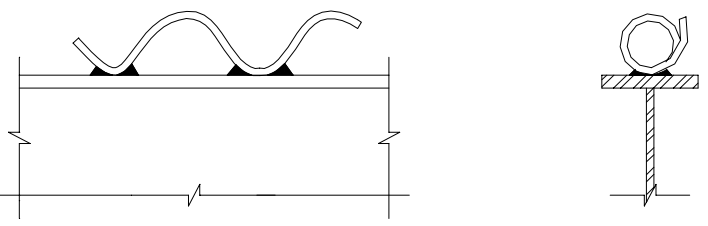

d) Espiral
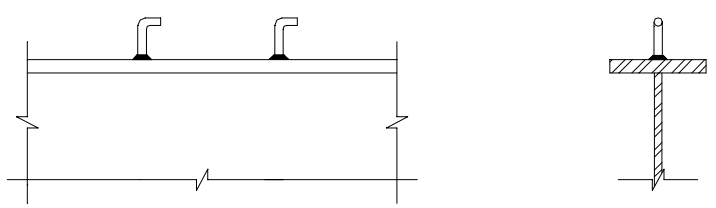

e) Pino com gancho

FIGURA 2.1: Tipos usuais de conectores

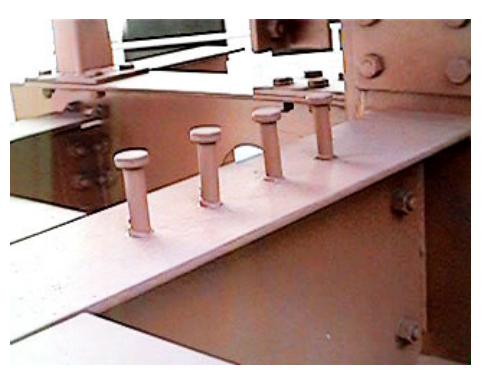

Conector tipo pino com cabeça

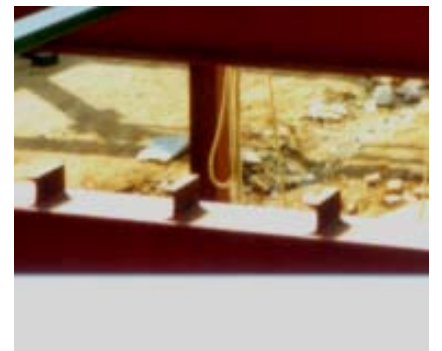

Conector tipo perfil " $U$ " laminado

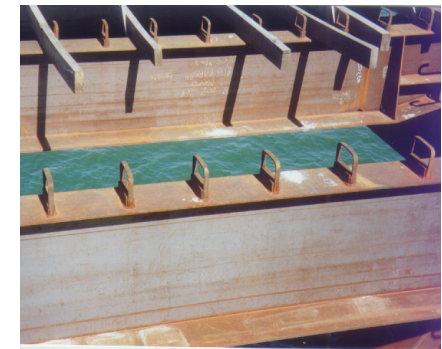

Conector tipo barra com alça

FIGURA 2.2: Exemplos de tipos de conectores 


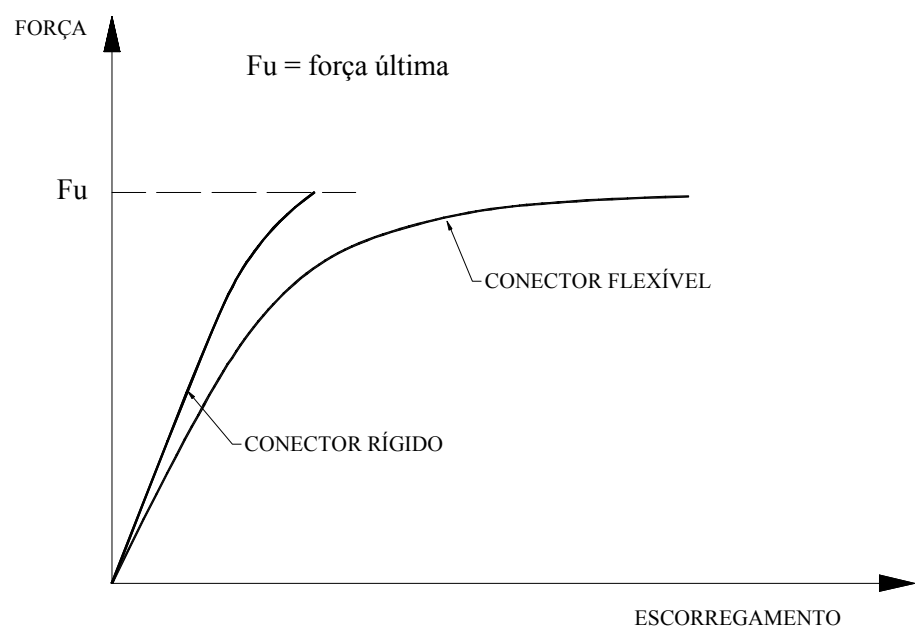

FIGURA 2.3: Curva Força x Escorregamento para conectores de cisalhamento

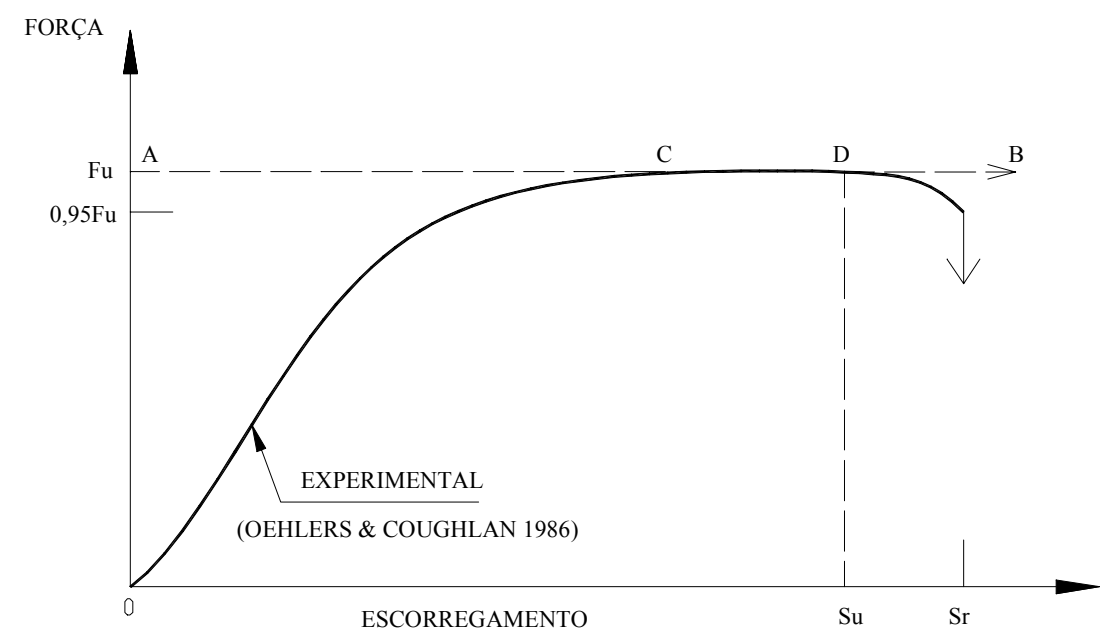

FIGURA 2.4: Diagrama força x escorregamento para conectores do tipo pino com cabeça embutidos em laje maciças

\subsection{CAPACIDADE DOS CONECTORES}

Com base em resultados experimentais, as normas apresentam expressões ou tabelas para a determinação da capacidade dos principais tipos de conectores de cisalhamento.

- Conectores do tipo pino com cabeça: 
A norma brasileira NBR 8800 (1986) e a americana AISC-LRFD (1994): "Load and Resistance Factor Design" apresentam a seguinte expressão para o cálculo da capacidade nominal do conector $\left(q_{n}\right)$ totalmente embutido em laje maciça de concreto:

$q_{n}=0,5 A_{s c} \sqrt{f_{c k} E_{c}} \leq A_{s c} f_{u}$

onde

$A_{s c}$ é a área da seção transversal do conector;

$f_{c k}$ é a resistência característica do concreto à compressão $(\mathrm{MPa})$;

$E_{c}$ é o módulo de elasticidade do concreto $(\mathrm{MPa}) ; E_{c}=42 \gamma_{c}^{1,5} \sqrt{f_{c k}}$;

$\gamma_{c}$ é o peso específico do concreto em $\mathrm{KN} / \mathrm{m}^{3}$;

$f_{u}$ é a resistência à ruptura do aço do conector.

A norma brasileira limita o uso da expressão (2.1) para concretos $\operatorname{com} f_{c k} \leq 28 \mathrm{MPa}$. No caso de lajes com fôrmas de aço incorporadas (figura 2.5), a norma brasileira e a americana apresentam um coeficiente de redução, o qual deve ser multiplicado pelo valor da resistência nominal calculada conforme a expressão (2.1). Esse coeficiente de redução é obtido a partir das expressões (2.2) e (2.3):

- Para fôrmas colocadas com nervuras paralelas à viga de aço:

$C_{\text {red }}=0,6\left(\frac{b_{F}}{h_{F}}\right)\left(\frac{h_{c s}}{h_{F}}-1\right) \leq 1,0$

- Para fôrmas colocadas com nervuras perpendiculares à viga de aço:

$C_{\text {red }}=\frac{0,85}{\sqrt{n_{c s}}}\left(\frac{b_{F}}{h_{F}}\right)\left(\frac{h_{c s}}{h_{F}}-1\right) \leq 1,0$

onde 
$h_{c s}$ é a altura total do pino, não superior a $h_{F}+75 \mathrm{~mm}$ nos cálculos;

$n_{c s}$ é o número de conectores de cisalhamento por nervura, por viga, não superior a 3 para efeito de cálculo;

$b_{F}$ é a largura da nervura;

$h_{F}$ é a altura nominal da nervura.

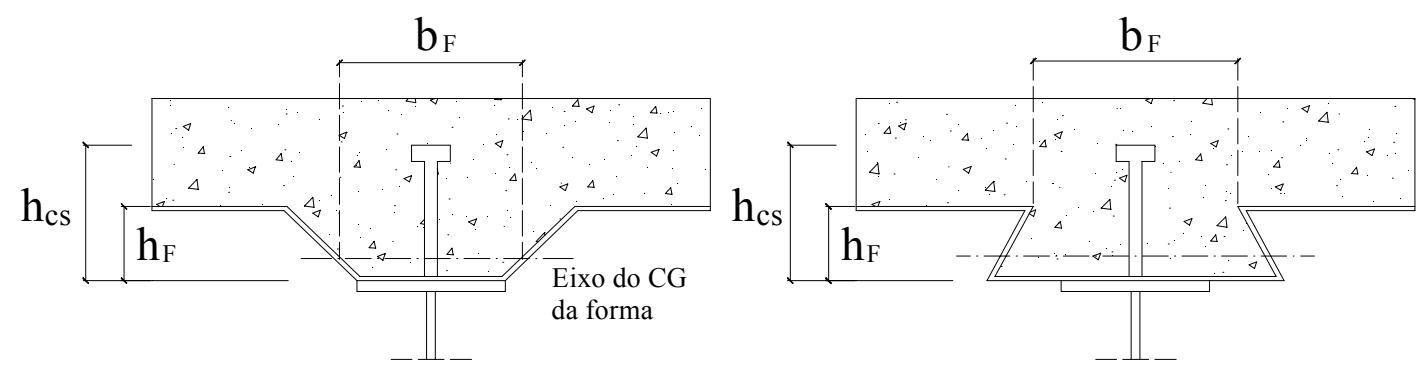

FIGURA 2.5: Lajes com fôrmas de aço incorporadas

A norma canadense CAN/CSA-S16.1 (1994): "Limits States Design of Steel Structures" apresenta a mesma expressão da norma americana para o cálculo da capacidade nominal do conector tipo pino com cabeça em lajes maciças. Para obter a resistência de cálculo do conector, multiplica-se a resistência nominal pelo coeficiente de resistência $\phi_{s c}=0,80$.

A norma canadense apresenta também expressões para o cálculo da resistência de conectores em lajes com fôrma de aço incorporada, com nervuras paralelas e com nervuras perpendiculares à viga de aço.

Segundo a norma européia EUROCODE 4 (1992): "Design of composite steel and concrete structures", a resistência de cálculo do conector $q_{R d}$ é assumida como o menor dos seguintes valores:

$q_{R d}=\frac{0,8 f_{u}\left(\frac{\pi d^{2}}{4}\right)}{\gamma_{v}}$ e $q_{R d}=\frac{0,29 \alpha d^{2} \sqrt{f_{c k} E_{c}}}{\gamma_{v}}$

onde

$d$ é o diâmetro do corpo do conector; 
$f_{u}$ é a resistência à ruptura do aço do conector;

$f_{c k}$ é a resistência característica do concreto à compressão (MPa);

$E_{c}$ é o módulo de elasticidade do concreto (MPa);

$\alpha=0,2\left(\frac{h_{c s}}{d}+1\right)$ para $3 \leq \frac{h_{c s}}{d} \leq 4 ;$

$\alpha=1,0$ para $\frac{h_{c s}}{d}>4$;

$h_{c s}$ é a altura total do pino;

$\gamma_{v}$ é o coeficiente de resistência, igual a 1,25.

Em lajes com fôrmas de aço incorporadas, a resistência de cálculo do conector é igual à resistência no caso de laje maciça multiplicada por um fator de redução, dado pelas expressões (2.2) e (2.3), conforme a norma brasileira e a americana, devendo-se apenas substituir o fator 0,85 por 0,7 .

Segundo a norma britânica BS 5950 (1990): "Structural use of steelwork in building", a resistência de cálculo dos conectores em lajes maciças é dada por:

a) Sob momento positivo:

$q_{R d}=0,8 q_{n}$

b) Sob momento negativo:

$q_{R d}=0,6 q_{n}$

onde

$q_{n}$ é a resistência nominal do conector.

Esta norma apresenta uma tabela que contém os valores da resistência nominal de conectores tipo pino com cabeça, conforme a tabela 2.1. Para a utilização desta tabela, o material do conector deve atender às seguintes propriedades mecânicas: tensão de ruptura $($ mín. $)=450 \mathrm{MPa}$; alongamento $($ mín. $)=15 \%$. 
TABELA 2.1: Resistência nominal de conectores tipo pino com cabeça em lajes maciças, segundo a BS 5950.

\begin{tabular}{|c|c|c|c|c|c|}
\hline \multicolumn{2}{|c|}{ Dimensões do conector } & \multicolumn{4}{|c|}{ Resistência nominal do conector $(\mathrm{kN})$} \\
\hline Diâmetro & Altura & \multicolumn{4}{|c|}{ Resistência característica do concreto $f_{c k}(\mathrm{MPa})$} \\
\hline$(\mathrm{mm})$ & $(\mathrm{mm})$ & 25 & 30 & 35 & 40 \\
\hline 25 & 100 & 146 & 154 & 161 & 168 \\
\hline 22 & 100 & 119 & 126 & 132 & 139 \\
\hline 19 & 100 & 95 & 100 & 104 & 109 \\
\hline 19 & 75 & 82 & 87 & 91 & 96 \\
\hline 16 & 75 & 70 & 74 & 78 & 82 \\
\hline 13 & 65 & 44 & 47 & 49 & 52 \\
\hline \multicolumn{6}{|c|}{$\begin{array}{l}\text { Nota1: Para concretos com } f_{c k}>40 \mathrm{MPa} \text {, utilizar os valores para } f_{c k}=40 \mathrm{MPa} \text {. } \\
\text { Nota2: Para conectores com alturas maiores que as tabeladas, utilizar o valo } \\
\text { correspondente à maior altura tabelada. }\end{array}$} \\
\hline
\end{tabular}

Em lajes com fôrmas de aço incorporadas, a resistência de cálculo do conector é igual ao caso de laje maciça multiplicada por um fator de redução $C_{r e d}$. Quando as nervuras são paralelas à viga de aço e a relação $b_{F} / h_{F}$, conforme a figura 2.5, for menor que 1,5, o coeficiente $C_{r e d}$ deve ser determinado a partir da expressão (2.2); para relações $b_{F} / h_{F}$ maiores que $1,5, C_{r e d}=1,0$. Quando as nervuras são perpendiculares à viga de aço, o coeficiente de redução é calculado conforme as seguintes expressões:

- Para um conector por nervura:

$C_{\text {red }}=0,85\left(\frac{b_{F}}{h_{F}}\right)\left(\frac{h_{c s}}{h_{F}}-1\right) \leq 1,0$

- Para dois conectores por nervura:

$C_{\text {red }}=0,6\left(\frac{b_{F}}{h_{F}}\right)\left(\frac{h_{c s}}{h_{F}}-1\right) \leq 0,8$ 
- Para três ou mais conectores por nervura:

$$
C_{r e d}=0,5\left(\frac{b_{F}}{h_{F}}\right)\left(\frac{h_{c s}}{h_{F}}-1\right) \leq 0,6
$$

As expressões (2.7), (2.8) e (2.9), apresentadas pela norma britânica, conduzem aos mesmos coeficientes de redução obtidos da expressão (2.3) fornecida pelas normas NBR 8800 e AISC-LRFD, para o caso de nervuras perpendiculares à viga de aço.

\section{- Outros tipos de conectores:}

As normas AISC-LRFD (1994), NBR-8800 (1986) e CAN/CSA-S16.1 (1994) apresentam uma expressão para o cálculo da resistência nominal de conectores tipo perfil "U" laminado:

$q_{n}=0,0365\left(t_{f}+0,5 t_{w}\right) L_{c} \sqrt{f_{c k}}$

onde

$t_{f}$ é a espessura média da mesa do conector em mm;

$t_{w}$ é a espessura da alma do conector em mm;

$L_{c}$ é o comprimento do perfil "U" laminado em $\mathrm{mm}$.

A norma brasileira limita o uso da expressão (2.10) a concretos com peso específico superior a $22 \mathrm{KN} / \mathrm{m}^{3}$ e com $20 \mathrm{MPa} \leq f_{c k} \leq 28 \mathrm{MPa}$. A norma canadense limita o uso da expressão (2.7) para concretos com $f_{c k} \geq 20 \mathrm{MPa}$ e com peso específico superior a $23 \mathrm{KN} / \mathrm{m}^{3}$.

A BS 5400 (1979) apresenta uma tabela com a resistência nominal de conectores tipo perfil "U" laminado e barra chata. Essa tabela é adaptada e reproduzida na tabela 2.2 . 
TABELA 2.2: Resistência nominal de conectores tipo perfil " $U$ " laminado e barra chata segundo a BS 5400

\begin{tabular}{|c|c|c|c|c|c|}
\hline Tipo & \multirow{3}{*}{$\begin{array}{c}\text { Material } \\
\text { do } \\
\text { conector }\end{array}$} & \multicolumn{4}{|c|}{ Resistência do conector $(k N)$} \\
\hline De & & \multicolumn{4}{|c|}{ Res. caract. do concreto - $f_{c k}(\mathrm{MPa})$} \\
\hline Conector & & 20 & 30 & 40 & 50 \\
\hline barra chata $(\mathrm{mm})$ & \multirow{3}{*}{$\begin{array}{l}\text { Grau } 43 \text { da } \\
\text { BS 4360: } 1972\end{array}$} & & & & \\
\hline $50 \times 40 \times 200 \phi=20 \mathrm{~mm}$ & & 697 & 830 & 963 & 1096 \\
\hline $25 \times 25 \times 200 \phi=12 \mathrm{~mm}$ & & 348 & 415 & 482 & 548 \\
\hline perfil tipo "U" (mm) & \multirow{4}{*}{$\begin{array}{l}\text { Grau } 43 \text { da } \\
\text { BS 4360: } 1972\end{array}$} & & & & \\
\hline $127 \times 64 \times(14,90) \times 150$ & & 351 & 397 & 419 & 442 \\
\hline $102 \times 51 \times(10,42) \times 150$ & & 293 & 337 & 364 & 390 \\
\hline $76 \times 38 \times(6,70) \times 150$ & & 239 & 283 & 305 & 326 \\
\hline
\end{tabular}

MALITE at al. (1998) apresentaram os resultados experimentais de ensaios do tipo push-out em dois tipos de conectores (cantoneira e perfil "U") formados a frio para a avaliação do comportamento força-escorregamento e da resistência última. Os resultados desses ensaios foram comparados com aqueles obtidos a partir da expressão da norma americana AISC-LRFD (1994) e da norma brasileira NBR 8800 (1986) para o cálculo da resistência nominal de conectores em perfil "U" laminado, onde foi possível avaliar a possibilidade de se estender a expressão dessas normas para conectores formados a frio. A expressão proposta para o cálculo da resistência nominal de conectores tipo cantoneira e perfil "U" é dada por:

$q_{n}=0,00045 t L \sqrt{f_{c k} E_{c}}$

onde

$L$ é o comprimento do conector em chapa dobrada, em mm;

$t$ é a espessura do conector em chapa dobrada, em mm;

$f_{c k}$ é a resistência característica do concreto à compressão $(\mathrm{MPa})$;

$E_{c}$ é o módulo de elasticidade do concreto (MPa); $E_{c}=42 \gamma_{c}^{1,5} \sqrt{f_{c k}}$;

$\gamma_{c}$ é o peso específico do concreto em $\mathrm{kN} / \mathrm{m}^{3}$. 
TABELA 2.3: Comparação de resultados teóricos com resultados experimentais MALITE et al. (1998)

\begin{tabular}{|c|c|c|c|c|}
\hline $\begin{array}{c}\text { Tipo } \\
\text { Conector }\end{array}$ & $\begin{array}{c}\text { Dimensões } \\
(\mathrm{mm})\end{array}$ & $\begin{array}{c}\boldsymbol{Q}_{\boldsymbol{n}}(\boldsymbol{K N}) \\
\text { (expressão } \\
2.11 \text { ) }\end{array}$ & $\begin{array}{c}\boldsymbol{P}_{\boldsymbol{u}}(\boldsymbol{K N}) \\
\text { (experimental) }\end{array}$ & $\begin{array}{c}\text { Relação } \\
P_{u} / Q_{n}\end{array}$ \\
\hline A & $\begin{array}{ll}\frac{1}{1} & 50 \\
\frac{1}{1} & \end{array}$ & 104.7 & 124.2 & 1.19 \\
\hline B & $\underset{4}{+1.76}$ & 161.5 & 178.0 & 1.10 \\
\hline $\mathrm{C}$ & $\underset{2.66}{1} 40$ & 92.8 & 122.9 & 1.32 \\
\hline D & 7 & 170.6 & 185.8 & 1.09 \\
\hline $\begin{array}{l}\text { Obs. } \\
\text { a) Comprim } \\
\text { b) } P_{u} \text { refere }\end{array}$ & $\begin{array}{l}\text { dos conect } \\
\text { orça por c }\end{array}$ & mm colapso & lor médio) & \\
\hline
\end{tabular}

A expressão (2.11) deriva da expressão (2.10) para conectores tipo "U" laminados, mantendo-se iguais as espessuras da mesa e da alma do conector, característica dos perfis formados a frio. Por meio da comparação com os resultados obtidos experimentalmente, mostrados na tabela 2.3, concluiu-se que, na ausência de resultados experimentais, a expressão (2.11) é adequada para a determinação da resistência nominal de conectores do tipo cantoneira e perfil " $U$ ” formados a frio. 


\subsection{RECOMENDAÇÕES E RESTRIÇÕES SEGUNDO AS NORMAS}

As normas apresentam recomendações e restrições quanto à locação e espaçamento dos conectores. A NBR 8800 coloca as seguintes restrições:

a) Os conectores de cisalhamento, colocados de cada lado da seção de momento fletor máximo, podem ser uniformemente espaçados entre esta seção e as seções de momento nulo, exceto que, nas regiões de momento fletor positivo, o número de conectores necessários entre qualquer seção com carga concentrada e a seção adjacente de momento nulo (ambas situadas do mesmo lado, relativamente à seção de momento máximo) não pode ser inferior a n':

$$
n^{\prime}=n\left(\frac{M_{d}^{\prime}-\phi_{b} M_{a}}{M_{d}-\phi_{b} M_{a}}\right)
$$

onde

$n$ é o número de conectores de cisalhamento a serem colocados de cada lado da seção de momento fletor máximo;

$M_{d}^{\prime} \quad$ é o momento fletor de cálculo no ponto de carga concentrada (inferior ao momento máximo);

$\phi_{b} M_{a}$ é a resistência de cálculo ao momento fletor da viga de aço isolada, baseada no estado limite FLA (flambagem local da alma);

$M_{d}$ é o momento fletor máximo de cálculo.

b) o espaçamento máximo entre linhas de centro de conectores deve ser igual a oito vezes a espessura da total da laje, não sendo superior a $800 \mathrm{~mm}$ no caso de lajes com fôrma de aço incorporada com nervuras perpendiculares à viga.

c) O espaçamento mínimo entre linhas de centro de conectores tipo pino com cabeça deve ser igual a seis diâmetros ao longo do vão da viga e quatro diâmetros na direção transversal às mesmas.

d) Os conectores tipo pino com cabeça não podem ter diâmetro maior que 2,5 vezes a espessura da mesa à qual forem soldados, a menos que sejam colocados na posição correspondente à alma da viga. 
e) O cobrimento lateral de concreto para qualquer tipo de conector deve ser no mínimo igual a $25 \mathrm{~mm}$, excetuando-se o caso de conectores colocados em nervuras de fôrma de aço.

De maneira geral, as restrições apresentadas pelas demais normas quanto à locação e espaçamento dos conectores são similares, existindo pequenas diferenças com relação à norma brasileira. Segundo o EUROCODE 4 , o espaçamento máximo entre linhas de centro de conectores deve ser igual a seis vezes a espessura da total da laje, não sendo superior a $800 \mathrm{~mm}$. Com relação aos conectores tipo pino com cabeça, o espaçamento mínimo entre linhas de centro deve ser igual a cinco diâmetros ao longo do vão da viga; na direção transversal, igual a 2,5 diâmetros no caso de lajes maciças e quatro diâmetros nos demais casos. O cobrimento mínimo para qualquer tipo de conector deve ser igual ao maior dos seguintes valores:

- 20mm;

- valor especificado pelo EUROCODE 2 (1991): "Design of concrete structures", para as armaduras, subtraindo-se $5 \mathrm{~mm}$.

Pela norma americana AISC-LRFD (1994), o espaçamento máximo entre linhas de centro de conectores deve ser igual a oito vezes a espessura da total da laje.

A norma canadense CAN/CSA-S16.1 (1994) estabelece que o espaçamento máximo entre linhas de centro de conectores tipo pino com cabeça deve ser igual a $1000 \mathrm{~mm}$.

A figura 2.6 ilustra as restrições das normas quanto à locação e espaçamento entre conectores do tipo pino com cabeça. 


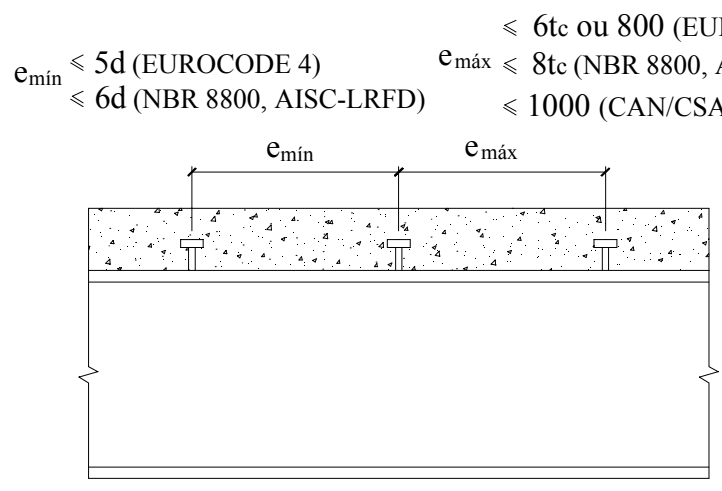

a) Espaçamento longitudinal máximo e mínimo entre conectores
$4 d(N B R 8800$, AISC-LRFD)

$2,5 \mathrm{~d} \mathrm{p} /$ lajes maciças

$4 \mathrm{~d} \mathrm{p} /$ as demais

(EUROCODE 4)

FIGURA 2.6: Restrições relativas à locação e espaçamento de conectores segundo as normas

\subsection{ENSAIOS EM CONECTORES DE CISALHAMENTO}

A avaliação do comportamento estrutural dos conectores de cisalhamento é possível pela realização de ensaios denominados push-out test. Esses ensaios permitem a obtenção da curva força-escorregamento, da força última e do modo de colapso da ligação. O EUROCODE 4 (1992) e a norma britânica BS 5400 (1979) apresentam procedimentos referentes aos ensaios do tipo push-out, que incluem a especificação das dimensões dos modelos a serem ensaiados e a determinação da capacidade nominal dos conectores.

A figura 2.7 contém detalhes do modelo adotado pelo EUROCODE 4 para o ensaio. O modelo consiste em um perfil de aço tipo "I" conectado a duas mesas de concreto através de conectores de cisalhamento. As mesas de concreto devem ser providas de armaduras, cuja posição e diâmetro das barras também são especificados tanto pelo EUROCODE 4 como pela norma britânica BS 5400.

O ensaio consiste basicamente na aplicação de força vertical ao perfil de aço, onde mede-se o escorregamento relativo entre a mesa de concreto e o perfil para cada incremento de carga, permitindo assim a construção da curva força-escorregamento.

Os possíveis modos de colapso são ilustrados na figura 2.8. O colapso também pode ser uma combinação desses modos. 

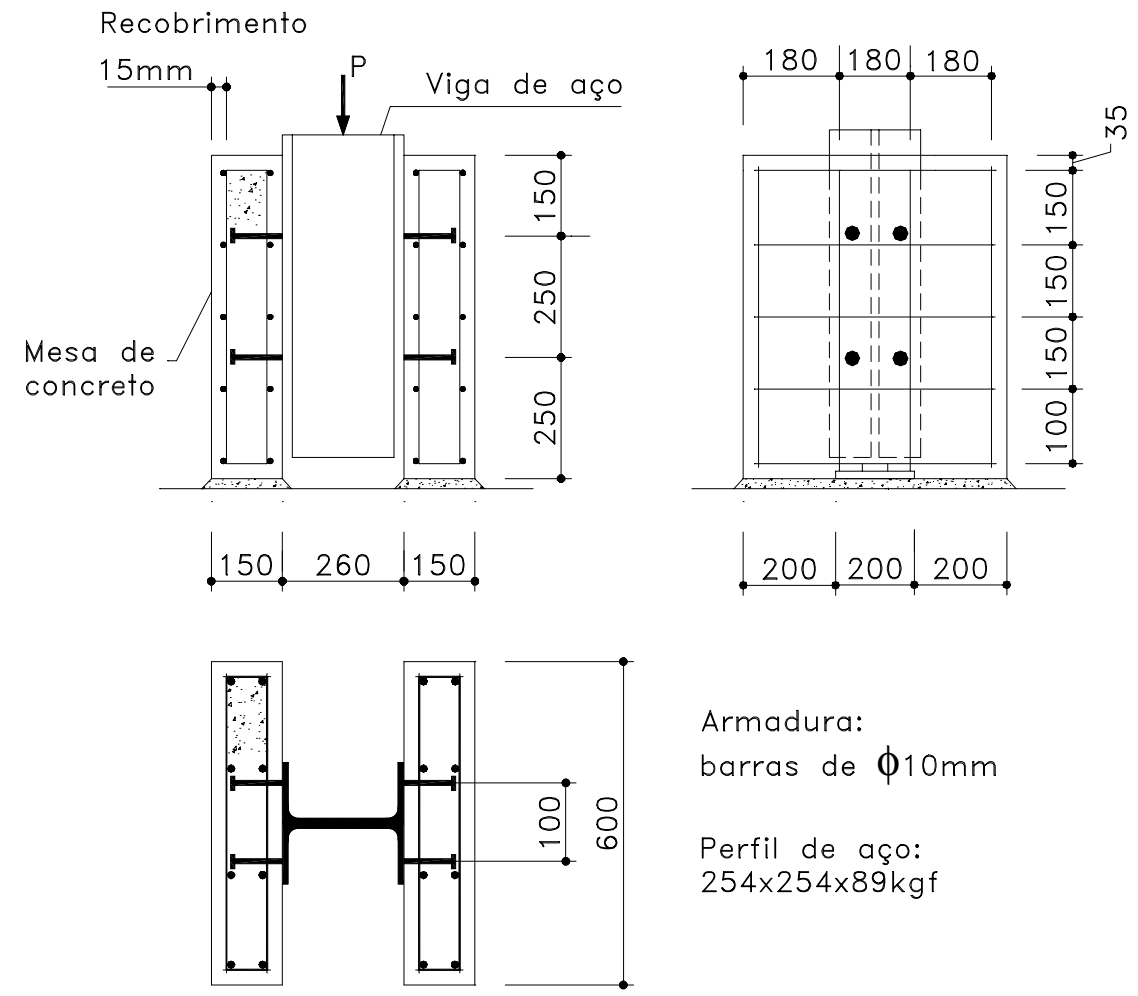

Armadura:

barras de $\phi 10 \mathrm{~mm}$

Perfil de aço:

$254 \times 254 \times 89 \mathrm{kgf}$

FIGURA 2.7: Modelo adotado pelo EUROCODE 4 para o ensaio tipo push-out

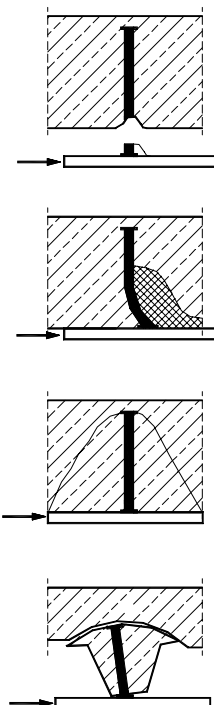

Ruptura por cisalhamento do conector junto à solda

Esmagamento do concreto ao redor do conector

Arrancamento do concreto (forma de cone)

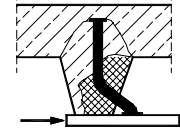

Fissuração do concreto da nervura, devido à formação de rótulas plásticas (deformações excessivas do conector)

FIGURA 2.8: Possíveis modos de colapso obtidos dos ensaios do tipo push-out 
A resistência à compressão do concreto é um parâmetro que influencia tanto o modo de colapso quanto a capacidade nominal do conector. A ruptura pode ocorrer por esmagamento, em concretos de resistência à compressão menores, enquanto que a ruptura por cisalhamento dos conectores pode ocorrer em concretos de resistência à compressão maiores. 


\subsection{INTRODUÇÃO}

As vigas mistas resultam da associação de uma viga de aço com uma laje de concreto, cuja ligação é feita por meio de conectores de cisalhamento, soldados à mesa superior do perfil. Em edifícios, o perfil mais utilizado como viga de aço é do tipo "I". As lajes de concreto podem ser moldadas in loco, com face inferior plana ou com fôrma de aço incorporada, ou ainda, podem ser formadas de elementos préfabricados (figuras 1.1 e 1.3 do capitulo 1). Alguns dos tipos mais usuais de seções de vigas mistas são indicados na figura 3.1.

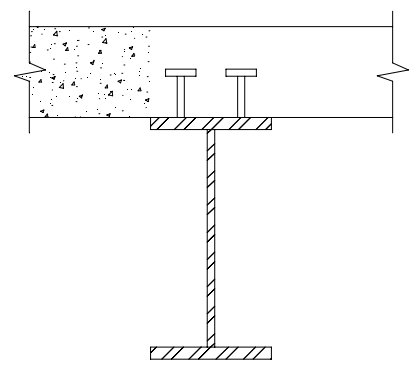

a) Laje com face inferior plana

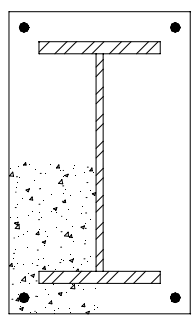

c) Viga de aço totalmente embutida no concreto

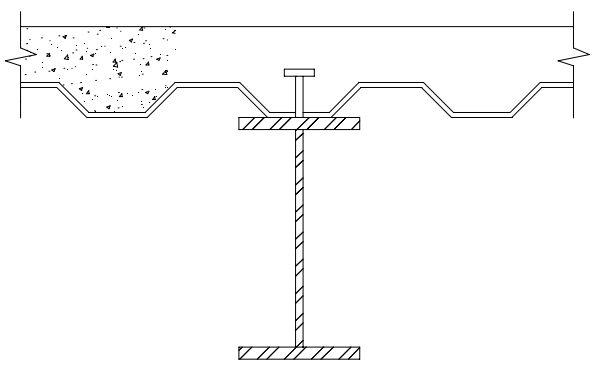

b) Laje com fôrma de aço incorporada

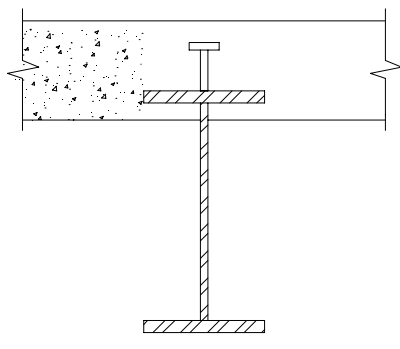

d) Viga de aço parcialmente embutida no concreto

FIGURA 3.1: Alguns tipos mais usuais de vigas mistas. MALITE (1990) 
Uma das vantagens da utilização de vigas mistas em sistemas de pisos é o acréscimo de resistência e de rigidez propiciados pela associação dos elementos de aço e de concreto, o que possibilita a redução da altura dos elementos estruturais, implicando em economia de material. A principal desvantagem reside na necessidade de provisão dos conectores de cisalhamento na interface aço-concreto.

As vigas mistas podem ser simplesmente apoiadas, o que é mais usual, ou podem ser contínuas. As simplesmente apoiadas, conforme mencionado no capítulo 1 , contribuem para a maior eficiência do sistema misto, pois a viga de aço trabalha predominantemente à tração e a laje de concreto à compressão. As vigas contínuas, devido à presença de momentos fletores negativos, apresentam um comportamento estrutural diferente das simplesmente apoiadas. Embora a presença exclusiva de momentos fletores positivos contribua para a maior eficiência do sistema misto, deve-se notar que a continuidade das vigas traz vantagens sob o ponto de vista de estabilidade global da estrutura, devido ao efeito de pórtico. As vigas mistas contínuas são abordadas com mais profundidade no item 3.3.2.

Com relação ao método construtivo, pode-se optar pelo não escoramento da laje devido à necessidade de velocidade de construção. Por outro lado, o escoramento da laje pode ser apropriado caso seja necessário limitar os deslocamentos verticais da viga de aço na fase construtiva.

\subsection{COMPORTAMENTO ESTRUTURAL}

O dimensionamento de vigas mistas submetidas à flexão depende da caracterização do comportamento ao nível da ligação aço-concreto. Duas situações são conhecidas nesse caso: a interação completa e a interação parcial.

$\mathrm{Na}$ interação completa, considera-se que existe uma ligação perfeita entre o aço e concreto, podendo-se assumir, dessa maneira, a hipótese corrente de seções planas permanecerem planas. Neste caso, não há escorregamento longitudinal nem afastamento vertical relativo. Desse modo, com relação a distribuição de deformações, verifica-se a existência de uma única linha neutra, conforme mostra, de maneira simplificada, a figura 3.2. 
Quando ocorre escorregamento relativo ao nível da ligação aço-concreto, há uma descontinuidade no diagrama de deformações, caracterizando a interação parcial. Em conseqüência disso, a seção transversal da viga apresenta duas linhas neutras. O efeito do escorregamento afeta a distribuição de tensões na seção, a distribuição do fluxo de cisalhamento longitudinal na conexão e, consequentemente, a deformabilidade das vigas. Esta última é relevante em verificações no regime de utilização da estrutura. $\mathrm{O}$ acréscimo de deslocamentos, provocado pelo efeito de escorregamento na interação parcial, é considerado pela normas em geral.

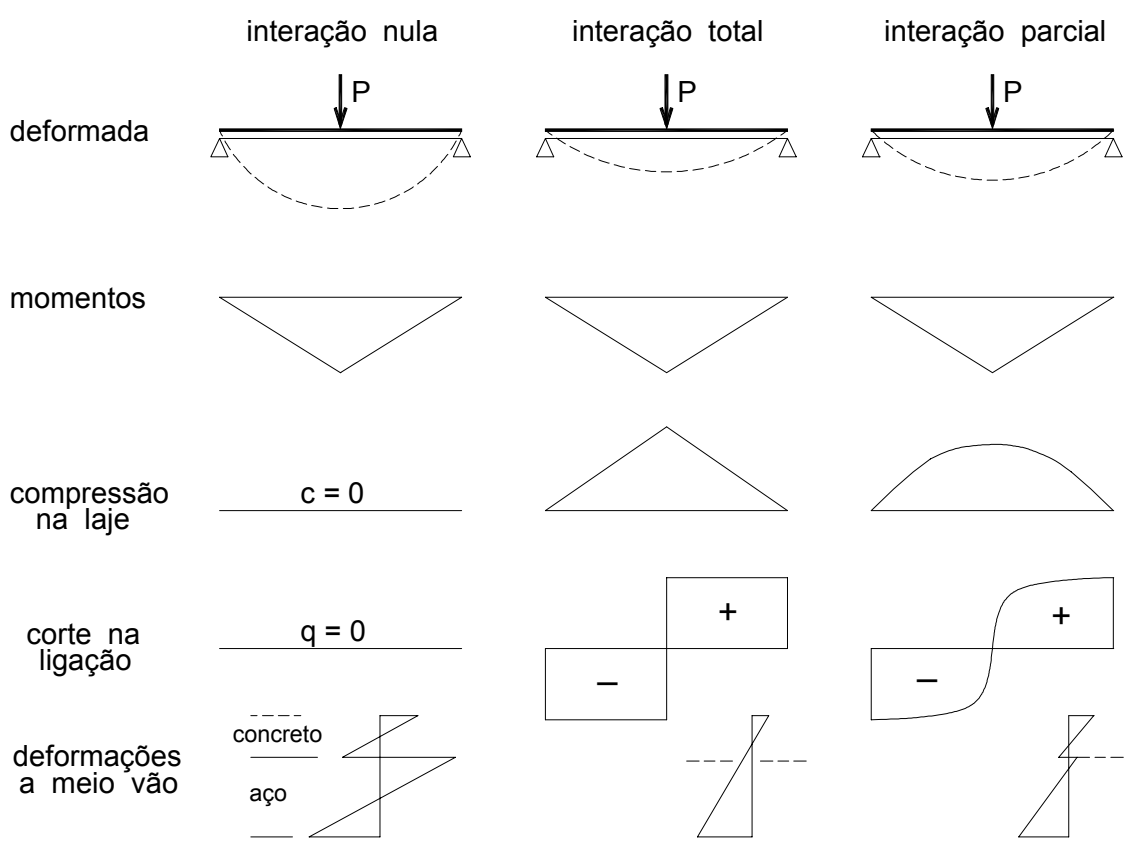

FIGURA 3.2: Interação aço-concreto no comportamento de vigas mistas

A provisão adequada de conectores de cisalhamento pode produzir um acréscimo não somente na resistência ao momento fletor, mas também na rigidez da viga. Isso pode conduzir a uma redução de custos, visto a possibilidade de se reduzir as dimensões da seção para o mesmo carregamento.

A ligação entre o aço e o concreto é dimensionada em função do diagrama de esforços cortantes longitudinais por unidade de comprimento $q$, conhecido como fluxo de cisalhamento longitudinal. 
No caso de interação completa, a resultante do diagrama do fluxo de cisalhamento longitudinal, aqui representada por $V_{h}$, é dada em função da máxima força cortante que se pode transmitir através da ligação, sendo esta limitada pelas resultantes máximas de tração e de compressão que podem atuar na viga de aço e na laje de concreto, respectivamente. $V_{h}$ assume, portanto, o menor desses valores. $\mathrm{O}$ número de conectores, no caso de interação completa, deve então ser determinado para a resistir à resultante $V_{h}$.

Do ponto de vista da resistência da ligação aço-concreto, define-se o termo grau de conexão $g$ pela relação entre o somatório das resistências individuais dos conectores - situados entre uma seção de momento fletor máximo e a seção adjacente de momento nulo - e a resultante do fluxo de cisalhamento $V_{h}$ da interação completa. Este índice permite avaliar o tipo de interação: quando $g$ for maior ou igual a 1, a interação é completa; caso contrário, a interação será parcial. O momento fletor resistente de uma viga mista depende do grau de conexão, sendo crescente no intervalo $0 \leq g \leq 1,0$.

Embora se confundam, na prática, os termos interação completa e conexão total (quando $g=1,0$ ), existe distinção entre interação, que está associado com o escorregamento relativo, e grau de conexão, que está associado à capacidade da viga em atingir o máximo momento resistente sem a ruptura da ligação. MALITE (1990) ressalva que, na realidade, algum escorregamento relativo ocorre, mesmo em vigas com grau de conexão total, e que o termo interação completa continua sendo usado, principalmente nas normas, pois entende-se que o escorregamento relativo entre aço e concreto pode ser desprezado nos cálculos.

OEHLERS et al. (1997) descreveram o efeito da interação parcial em vigas mistas com grau de conexão total. Mostraram que, para vigas mistas usuais em edifícios, onde a resultante de compressão da seção de concreto é maior que a resultante de tração na seção de aço, a interação parcial tem poucos efeitos sobre a capacidade da viga à flexão. Por outro lado, a interação parcial pode reduzir a resistência de vigas mistas com seções robustas de aço, onde a resultante de tração na seção de aço seja consideravelmente maior que a resultante de compressão no concreto. Entretanto, o grande efeito da interação parcial parece estar relacionado com a redução das deformações nos elementos de aço. 
A estabilidade local e global devem ser verificadas, assim como no casos de estruturas metálicas "puras". Em vigas mistas sob momentos positivos, a estabilidade local da mesa comprimida é garantida pela ligação desta com a laje de concreto, através de conectores. A estabilidade lateral também é garantida nas partes superiores comprimidas do perfil de aço, devido a presença da laje de concreto, que é tida como de rigidez infinita no seu plano.

Em geral, a flambagem local da viga de aço não é determinante em vigas de edifícios, onde as relações $h_{w} / t_{w}$ são relativamente pequenas. Além disso, devido às dimensões usuais de lajes em edifícios, em que a área de concreto assume valores consideráveis, a posição da linha neutra na viga de aço não possibilita grandes zonas comprimidas na alma.

O método construtivo também influencia o dimensionamento. No caso de construção não escorada, a viga de aço isolada deve ser capaz de resistir às solicitações provenientes do peso próprio da estrutura e das sobrecargas de construção. As verificações de flechas e da estabilidade lateral podem ser determinantes, neste caso.

\subsubsection{LARGURA EFETIVA}

O conceito de largura efetiva permite levar em consideração o efeito "shear lag" relacionado com a distribuição de tensões axiais na laje. A teoria elementar da flexão em vigas supõe que as tensões axiais não variam ao longo da mesa de uma viga. Entretanto, sabe-se que, quando a largura é muito grande, a partir de uma certa distância do eixo da alma viga, trechos da mesa não trabalham inteiramente ao momento fletor, conforme ilustra a figura 3.3. Portanto, a viga é menos rígida que o indicado pela teoria elementar da flexão. No entanto, é usual substituir a largura real das mesas por uma largura reduzida, de modo que a referida teoria elementar da flexão, aplicada nesta viga de seção transversal transformada, forneça o valor correto da máxima tensão de flexão. Esta largura reduzida da mesa é denominada largura efetiva. O cálculo exato da largura efetiva no regime elástico depende de uma série de fatores, tais como: 
- condições de apoio;

- tipo do carregamento e, consequentemente, da distribuição de momentos;

- proporção existente entre a espessura da laje e a altura da viga;

- armadura longitudinal colocada na laje de concreto.

O cálculo exato da largura efetiva, o qual encontra base na teoria da elasticidade, torna-se muito trabalhoso, visto que é necessário avaliar não somente os fatores já citados, como também resolver as equações que regem o fenômeno, o que inviabiliza seu cálculo em nível de projeto. Por esse motivo, o efeito "shear lag" é levado em consideração pelas normas através de recomendações práticas para a determinação do valor da largura efetiva.

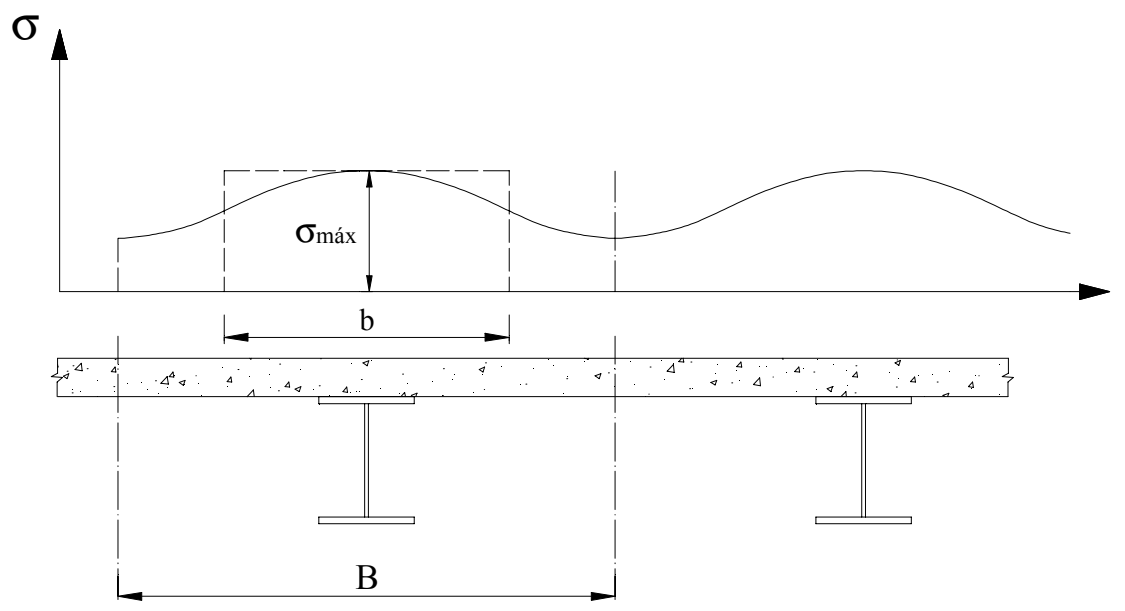

FIGURA 3.3: Distribuição das tensões longitudinais na laje considerando o efeito "Shear Lag"

\section{NBR-8800 (1986):}

Quando a laje se estende para ambos os lados da viga, a largura efetiva é determinada pelo menor dos seguintes valores:

a) 1/4 do vão da viga mista;

b) 16 vezes a espessura da laje mais a largura da mesa superior da viga de aço;

c) a largura da mesa superior da viga de aço mais a média das distâncias livres entre essa mesa e as mesas superiores das vigas adjacentes. 
O critério que considera a espessura da laje na determinação da largura efetiva, conforme o item b), vem sendo abandonado, além de não ser utilizado pelas demais normas.

Quando a laje se estende apenas para um lado da viga de aço, porém recobre totalmente sua mesa superior, a largura efetiva não pode ser maior que a largura desta mesa mais a menor das seguintes larguras:

a) 1/12 do vão da viga mista;

b) 6 vezes a espessura da laje;

c) metade da distância livre entre mesas superiores da viga considerada e da viga adjacente.

\section{AISC-LRFD (1994):}

A largura efetiva em cada lado da viga é determinada pelo menor dos seguintes valores:
a) $1 / 8$ do vão da viga mista;
b) metade da distância da viga considerada até o eixo da viga adjacente;
c) a distância do centro da viga até a borda da laje.

CAN/CSA - S16.1 (1994):

Quando a laje se estende para ambos os lados da viga, a largura efetiva é determinada pelo menor dos valores:

a) 1/4 do vão da viga mista;

b) a média das distâncias do eixo da viga considerada até o eixo das vigas adjacentes. 
Quando a laje se estende apenas para um lado da viga de aço, a largura efetiva não deve ser maior que a soma da largura da mesa superior com o menor dos seguintes valores:

a) $1 / 10$ do vão da viga mista;

b) metade da distância livre entre as mesas superiores da viga considerada e a viga adjacente.

\section{EUROCODE 4 (1994) e BS 5950 (1990):}

A largura efetiva, para efeito de dimensionamento e verificação de seções transversais, deve ser determinada como se segue:

- Para vigas simplesmente apoiadas e quando a laje se estende para ambos os lados, a largura efetiva pode ser considerada igual a 1/4 do vão da viga mista, porém não sendo maior que a média das distâncias entre eixos de vigas adjacentes. Quando a laje se estende para um lado apenas, a largura efetiva pode ser tomada igual a 1/8 do vão da viga, não sendo maior que a metade da distância entre a viga analisada e a viga adjacente.

- Para vigas contínuas, a largura efetiva em cada lado da viga pode ser considerada igual a $L_{o} / 8$, porém não superior à média das distâncias do eixo da viga analisada aos eixos das vigas adjacentes. $L_{o}$ é a distância entre seções de momento nulo. Os valores de $L_{o}$ podem ser obtidos a partir da figura 3.4, onde os valores de $L_{o}$ anotados na parte superior da viga aplicam-se aos apoios e os anotados na parte inferior, aplicam-se à metade do vão. 


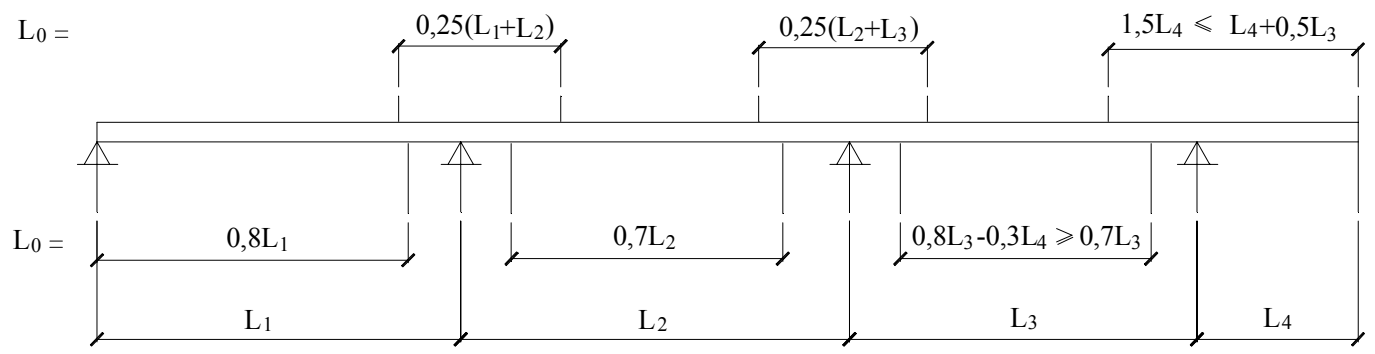

FIGURA 3.4: Valores de $L_{o}$ para vigas contínuas segundo o EUROCODE 4

A figura 3.5 mostra um exemplo de determinação da largura efetiva para uma viga contínua com três tramos de vãos iguais a $L$ e um balanço, de vão $0,25 L$.

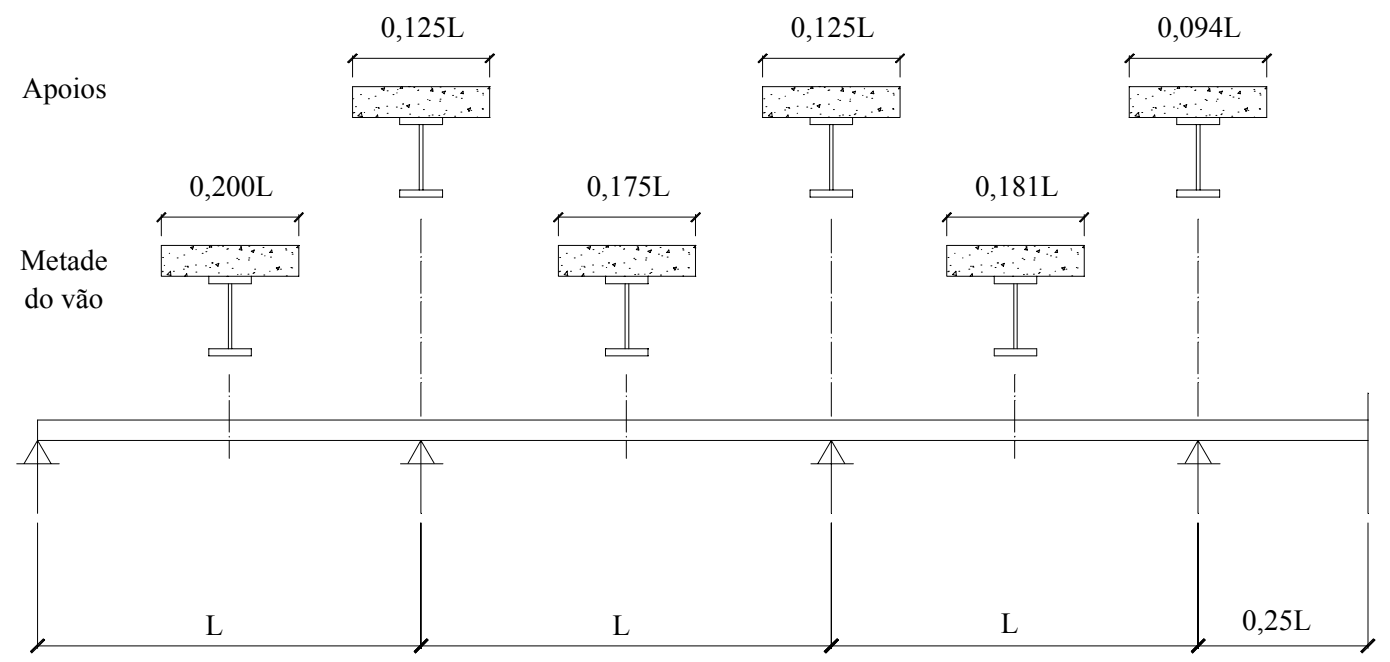

FIGURA 3.5: Exemplo de determinação da largura efetiva para vigas contínuas segundo o EUROCODE 4

BROSNAN \& UANG (1995) propõem uma expressão para o cálculo da largura efetiva de vigas mistas tipo "L", ou seja, quando a laje se estende apenas para um lado da viga. Tal expressão foi resultado de análise de diversos modelos utilizando-se o método dos elementos finitos com o auxílio do programa ANSYS. Foram estudados diversos modelos com vãos e espaçamentos entre vigas mais usuais em projetos de edifícios. A expressão proposta é válida para vigas com carregamento uniformemente distribuído e consiste em:

$b=0,330 L-0,406 s_{v}$ 
onde

$b$ é a largura efetiva;

$L$ é o vão da viga mista;

$s_{v}$ é o espaçamento entre vigas.

A tabela 3.1 apresenta uma comparação entre resultados obtidos a partir da equação (3.1) proposta por BROSNAN \& UANG (1995). Para a elaboração da tabela 3.1, considerou-se vigas mistas simplesmente apoiadas, cujos perfis de aço apresentam mesa superior de largura igual a $200 \mathrm{~mm}$ e espessura da laje de concreto igual a 15 $\mathrm{cm}$. Utilizou-se relações $s_{v} / L$ usuais em edifícios.

TABELA 3.1: Comparação dos valores de largura efetiva para vigas mistas que se estendem apenas para um dos lados (vigas tipo " $L$ ”)

\begin{tabular}{|c|c|c|c|c|c|c|}
\hline \multirow[t]{2}{*}{$\begin{array}{c}\boldsymbol{L} \\
(\mathrm{m})\end{array}$} & \multirow[t]{2}{*}{$\begin{array}{c}\boldsymbol{s}_{\boldsymbol{v}} \\
(\mathrm{m})\end{array}$} & \multirow[t]{2}{*}{$s_{v} / L$} & \multicolumn{4}{|c|}{$\begin{array}{c}\text { LARGURA EFETIVA } \\
(\mathrm{cm})\end{array}$} \\
\hline & & & $\begin{array}{l}\text { NBR } \\
8800\end{array}$ & $\begin{array}{l}\text { AISC- } \\
L R F D\end{array}$ & $\begin{array}{c}\text { EUROCODE } \\
4\end{array}$ & $\begin{array}{c}\text { BROSNAN } \\
\& U A N G\end{array}$ \\
\hline \multirow[t]{3}{*}{6,0} & 2,0 & 0,33 & 70 & 85 & 75 & 117 \\
\hline & 2,5 & 0,42 & 70 & 85 & 75 & 97 \\
\hline & 3,0 & 0,50 & 70 & 85 & 75 & 76 \\
\hline \multirow[t]{3}{*}{8,0} & 2,5 & 0,31 & 87 & 110 & 100 & 163 \\
\hline & 3,25 & 0,41 & 87 & 110 & 100 & 132 \\
\hline & 4,0 & 0,50 & 87 & 110 & 100 & 102 \\
\hline \multirow[t]{3}{*}{10,0} & 3,0 & 0,30 & 103 & 135 & 125 & 208 \\
\hline & 4,0 & 0,40 & 103 & 135 & 125 & 168 \\
\hline & 5,0 & 0,50 & 103 & 135 & 125 & 127 \\
\hline \multicolumn{7}{|c|}{ - Largura da mesa superior do perfil de aço: $200 \mathrm{~mm}$} \\
\hline
\end{tabular}


Com base na comparação feita na tabela 3.1, percebe-se que a norma brasileira NBR 8800 é mais conservadora no cálculo da largura para vigas tipo "L" em relação às demais normas e em relação à expressão proposta por BROSNAN \& UANG (1995).

Uma observação importante a ser citada é o fato de as normas apresentarem a determinação da largura efetiva apenas para as lajes maciças. Existe, assim, a necessidade de se fazer recomendações sobre a largura efetiva para outros tipos de lajes, como por exemplo o sistema de lajes formado por elementos pré-fabricados, o qual vem sendo muito utilizado.

\subsubsection{EFEITO DA FLUÊNCIA E DA RETRAÇÃO DO CONCRETO}

A fluência é usualmente associada com a redução do módulo de elasticidade do concreto em função do tempo. Como conseqüência, ocorre o aumento progressivo do coeficiente de homogeneização, ou seja, a relação entre o módulo de elasticidade do aço e do concreto.

Com relação à retração, a deformação resultante da redução do volume de concreto provoca deformações adicionais no elemento misto.

Assim, os efeitos da retração e fluência podem conduzir a deformações por carregamentos de longa-duração significativamente maiores que a sua deformação instantânea.

O EUROCODE 4 e a norma britânica BS 5950 recomendam a verificação dos efeitos de retração quando a relação vão/altura da viga mista for superior a 20 e

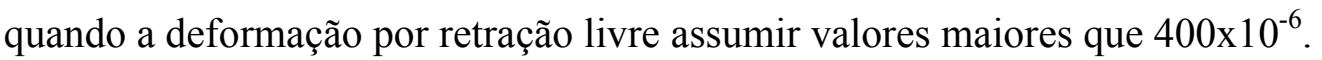

A norma canadense CAN/CSA-S16.1 (1994) considera o efeito da fluência através de uma redução do momento de inércia efetivo da viga mista. Esta norma também apresenta uma expressão para a consideração dos efeitos da retração no deslocamento vertical de vigas mistas simplesmente apoiadas, através da adoção de um valor para a deformação por retração livre.

BRADFORD \& GILBERT (1995) descrevem um modelo analítico de uma viga mista contínua formada por dois vãos iguais sob carregamento constante. Os 
efeitos da fluência, retração e fissuração na região de momento negativo foram analisados. As deformações e os esforços previstos pelo modelo teórico foram comparados com a resposta da viga obtida em laboratório durante 340 dias. A análise levou em conta a não-linearidade do material causada pela fissuração do concreto na região de momento negativo e as deformações causadas pelos efeitos da fluência e da retração. Os resultados experimentais e teóricos apresentaram uma concordância entre si. Os resultados também mostraram a influência da retração do concreto no comportamento de vigas mistas contínuas em regime de utilização.

WRIGHT et al. (1992) descrevem a análise do efeito da fluência e da retração em vigas mistas com interação parcial. Realizaram testes em dois tipos de vigas: a primeira, utilizando concreto de densidade normal, e a segunda, concreto de baixa densidade. O comportamento das vigas e as condições do meio (temperatura, umidade relativa, etc.) foram observados durante um período de dois anos. Para efeito de comparação de resultados e avaliação dos efeitos da fluência e retração, a norma britânica para estruturas de concreto (BS 8110/1986) foi utilizada como referência.

A partir dessa comparação, concluiu-se que os efeitos da fluência e da retração em vigas mistas formadas por concreto de baixa densidade podem ser menores que no caso de vigas mistas constituídas de concreto de densidade normal. Também concluiu-se que os métodos de cálculo disponíveis para a avaliação de flechas devido à fluência e retração do concreto tendem a subestimar estes deslocamentos no caso de vigas mistas constituídas por concreto de densidade normal. 


\subsection{DIMENSIONAMENTO SEGUNDO AS PRINCIPAIS NORMAS}

Neste item serão descritos os procedimentos de cálculo de algumas das principais normas que abordam o dimensionamento de vigas mistas. As normas referidas são a européia EUROCODE 4 (1992), a britânica BS 5950 (1990), a americana AISC-LRFD (1994), a canadense CAN/CSA-S16.1 (1994) e a brasileira NBR 8800 (1986). Serão descritos e analisados os procedimentos de cálculo de vigas mistas simplesmente apoiadas e vigas mistas contínuas submetidas à flexão simples segundo algumas destas normas.

\subsubsection{RESISTENNCIA AO MOMENTO FLETOR : REGIÃO DE MOMENTOS POSITIVOS}

\subsubsection{NBR 8800 (1986)}

A determinação do momento fletor resistente depende da classe à qual pertence a seção. A classe, neste caso, é referente à relação largura/espessura da alma.

A norma brasileira faz distinção entre dois tipos de seções:

- seções “compactas", pertencentes às classes 1 e 2, onde se permite a plastificação total da seção mista;

- seções "semi-esbeltas", pertencentes à classe 3, onde a alma pode sofrer flambagem local no regime inelástico.

Não se aceitam seções esbeltas (classe 4), ou seja, seções cuja alma pode sofrer flambagem local no regime elástico.

A figura 3.6 mostra a distribuição de tensões na qual se baseia a formulação da NBR 8800 (1986) para o cálculo do momento fletor resistente, no caso de interação completa. Da mesma maneira, pode-se obter a distribuição no caso de interação parcial. 


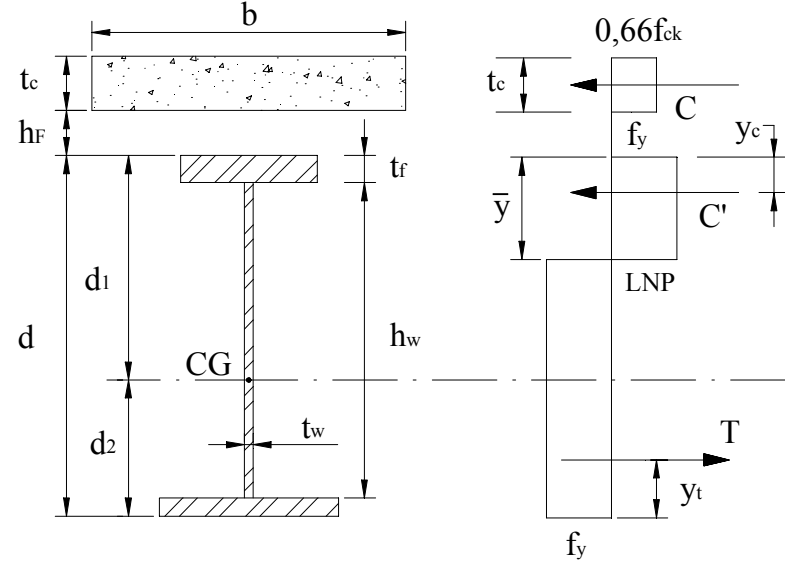

a) L.N.P. na alma

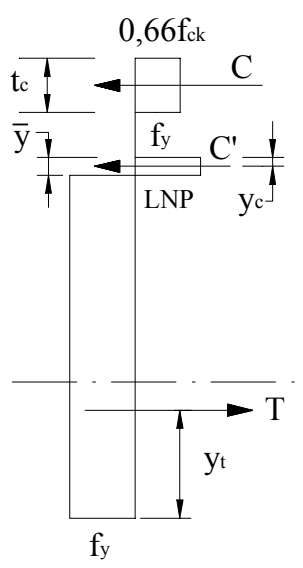

b) L.N.P. na mesa superior

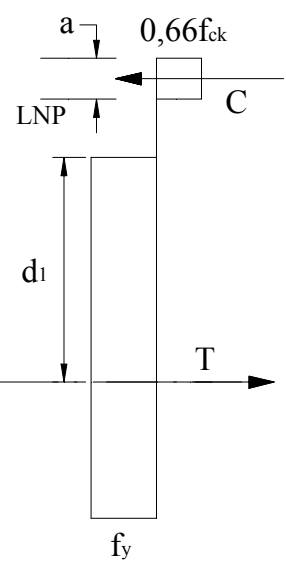

c) L.N.P. na laje

FIGURA 3.6: Tensões em vigas mistas sob momento positivo - Interação completa

$$
\left(h_{w} / t_{w} \leq 3,5 \sqrt{E / f_{y}}\right)
$$

a) Vigas "compactas": $\frac{h_{w}}{t_{w}} \leq 3,5 \sqrt{\frac{E}{f_{y}}}$

A resistência de cálculo para este caso é igual a $\phi_{b} M_{n}$, onde $\phi_{b}=0,90$ e $M_{n}$ é o momento nominal resistente. Três casos típicos são considerados:

a.1) Interação completa - Linha Neutra Plástica na Laje:

Ocorre se as seguintes condições são satisfeitas:

$Q_{n} \geq\left(A f_{y}\right)_{a}$ e $0,66 f_{c k} b t_{c} \geq\left(A f_{y}\right)_{a}$

O coeficiente 0,66 que multiplica $f_{c k}$ corresponde ao produto de 0,85 (efeito Rush) pela relação entre os coeficientes de segurança do concreto $(1 / 1,4 \cong 0,7)$ e do aço $(0,90)$ para este caso. Resumindo, $0,85 \times(0,7 / 0,9)=0,66$.

Logo: 
$C=0,66 f_{c k} b a$

$T=\left(A f_{y}\right)_{a}$

$a=\frac{\left(A f_{y}\right)_{a}}{0,66 f_{c k} b}<t_{c}$

$M_{n}=T\left(d_{1}+h_{F}+t_{c}-\frac{a}{2}\right)$

a.2) Interação Completa - Linha Neutra Plástica na viga de aço

Ocorre quando

$Q_{n} \geq 0,85 f_{c k} b t_{c}$ e $\left(A f_{y}\right)_{a} \geq 0,66 f_{c k} b t_{c}$

Logo:

$C=0,66 f_{c k} b t_{c}$

$C^{\prime}=0,5\left\{\left(A f_{y}\right)_{a}-C\right\}$

$T=C+C^{\prime}$

A posição da linha neutra plástica $(\bar{y})$, medida a partir do topo da viga de aço, pode ser determinada da seguinte forma:

- $\quad$ ara $C^{\prime} \leq\left(A f_{y}\right)_{t f}$ : linha neutra plástica na mesa superior

$\bar{y}=\frac{C^{\prime}}{\left(A f_{y}\right)_{t f}} t_{f}$

- $\quad$ para $C^{\prime}>\left(A f_{y}\right)_{t f}$ : linha neutra plástica na alma

$\bar{y}=\frac{C^{\prime}-\left(A f_{y}\right)_{t f}}{\left(A f_{y}\right)_{w}} h_{w}+t_{f}$ 
Portanto, $M_{n}$ é dado por:

$M_{n}=C^{\prime}\left(d-y_{t}-y_{c}\right)+C\left(\frac{t_{c}}{2}+h_{F}+d-y_{t}\right)$

a.3) Interação Parcial

Ocorre quando

$Q_{n}<0,85 f_{c k} b t_{c}$ e $Q_{n}<\left(A f_{y}\right)_{a}$

não sendo inferior à metade do menor desses valores, ou seja, o grau de conexão é limitado em 0,5. Cumpridas estas condições, então:

Neste caso, tem-se:

$C=\left(\frac{0,7}{0,9}\right) Q_{n}$

Para a determinação de C', T e $\bar{y}$ são válidas as expressões dadas no item a.2), com o novo valor de C. Assim,

$M_{n}=C^{\prime}\left(d-y_{t}-y_{c}\right)+C\left(t_{c}-\frac{a}{2}+h_{F}+d-y_{t}\right)$

onde:

$a=\frac{C}{0,66 f_{c k} b}$

Nas expressões dadas em a.1), a.2) e a.3):

$b$ é a largura efetiva da laje;

$t_{c}$ é a espessura da laje; 
$h_{F}$ é a altura nominal da nervura;

$a$ é a espessura comprimida da laje ou, para interação parcial, espessura considerada efetiva;

$d$ é a altura total da viga de aço;

$t_{f}$ é a espessura da mesa da viga de aço;

$h_{w}$ é a espessura da alma da viga de aço;

$f_{c k}$ é a resistência característica do concreto à compressão;

$Q_{n}=\Sigma q_{n}$, somatório das resistências nominais individuais " $q_{n}$ " dos conectores de cisalhamento situados entre a seção de momento máximo e a seção adjacente de momento nulo;

$d_{1}$ é a distância do centro de gravidade da seção da viga de aço até a face superior desta viga ;

$y_{c}$ é a distância do centro de gravidade da parte comprimida da seção da viga de aço até a face superior desta viga;

$y_{t}$ é a distância do centro de gravidade da parte tracionada da seção da viga de aço até a face inferior desta viga;

$\bar{y}$ é a distância da linha neutra da seção plastificada até a face superior da viga de aço;

$\left(A f_{y}\right)_{a}$ é o produto da área da seção da viga de aço pela sua tensão de escoamento;

$\left(A f_{y}\right)_{t f}$ é o produto da área da mesa superior da viga de aço pela tensão de escoamento;

$\left(A f_{y}\right)_{w}$ é o produto da área da alma da viga de aço pela tensão de escoamento.

b) Vigas "semi-esbeltas": $3,5 \sqrt{\frac{E}{f_{y}}}<\frac{h_{w}}{t_{w}} \leq 5,6 \sqrt{\frac{E}{f_{y}}}$

Neste caso, a tensão de tração de cálculo na mesa inferior da viga de aço não pode ultrapassar $\phi f_{y}$, sendo $\phi=0,90$ e a tensão de compressão de cálculo no concreto não pode ultrapassar $\phi^{\prime} f_{c k}$, sendo $\phi^{\prime}=0,70$.

No caso de interação completa, as tensões correspondentes ao momento solicitante de cálculo $M_{s d}$ devem ser determinadas pelo processo elástico, com base 
nas propriedades da seção mista homogeneizada. Para a obtenção da seção homogeneizada, divide-se a largura efetiva da laje por $n=E / E_{c}$, onde $E_{c}$ é o módulo de elasticidade do concreto. Despreza-se a participação do concreto na zona tracionada.

Dois casos são possíveis no processo elástico: quando a linha neutra se encontra na laje e quando a linha neutra se encontra na viga de aço. (figura 3.7)
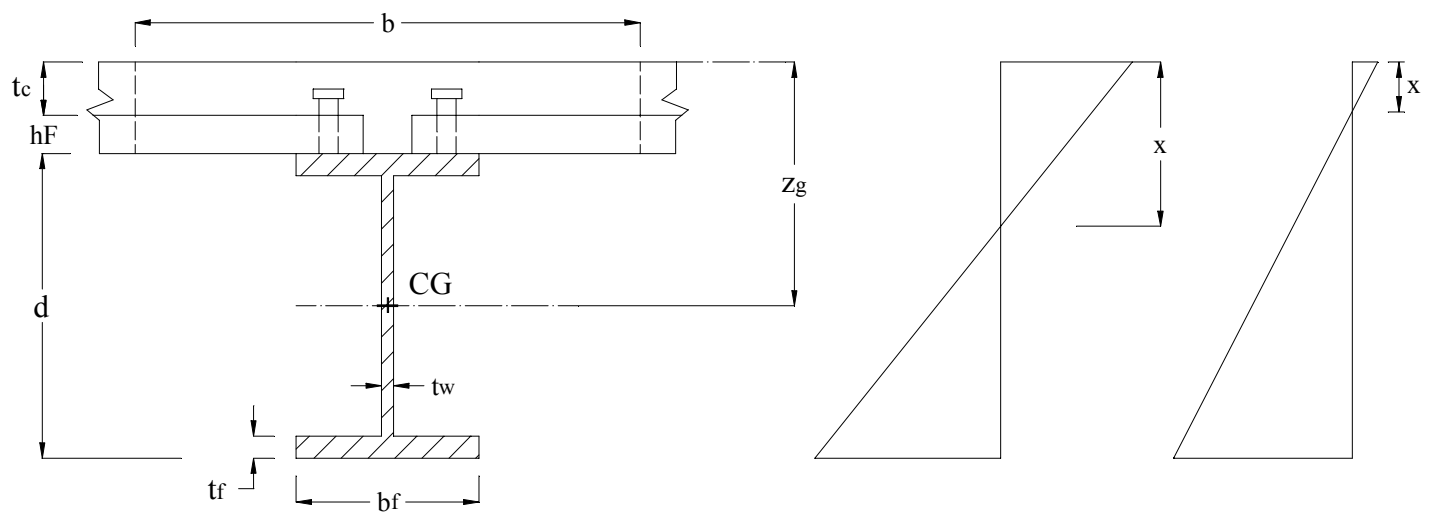
a) Seção da viga mista
b) L.N. na viga de aço
c) L.N. na laje

FIGURA 3.7: Deformações em vigas mistas sob momento positivo - Análise elástica/Interação completa

b.1) Linha Neutra na laje de concreto:

A posição da linha neutra, calculada desprezando-se a zona tracionada da laje e o concreto entre as nervuras, e o momento de inércia da seção homogeneizada $I_{t r}$ podem ser determinados pelas expressões:

$$
\begin{aligned}
& x=\frac{n A_{a}}{b}\left(\sqrt{1+\frac{2 b z_{g}}{n A_{a}}}-1\right) \\
& I_{t r}=I_{a}+A_{a}\left(z_{g}-x\right)^{2}+\frac{b x^{3}}{3 n}
\end{aligned}
$$

onde

$z_{g}$ é a distância entre o topo da laje e o centro de gravidade da viga de aço;

$I_{a}$ é o momento de inércia da viga de aço; 
$A_{a}$ é a área da seção transversal da viga de aço;

$x$ é a distância do topo da laje à linha neutra, conforme a figura 3.7;

$n$ é o fator de homogeneização, igual a $E / E_{c}$.

Os módulos de resistência elásticos da seção homogeneizada com relação à fibra inferior $\left(W_{t r}\right)_{i}$ e superior $\left(W_{t r}\right)_{s}$ são calculados por:

$$
\begin{aligned}
\left(W_{t r}\right)_{i} & =\frac{I_{t r}}{t_{c}+h_{F}+d-x} \\
\left(W_{t r}\right)_{s} & =\frac{I_{t r}}{x}
\end{aligned}
$$

A condição para que a linha neutra se encontre dentro da laje de concreto, ou seja, para que $x$ seja menor que $t_{c}$ é:

$$
A_{a}\left(z_{g}-t_{c}\right)<\frac{1}{2} b \frac{t_{c}^{2}}{n}
$$

b.2) Linha Neutra na viga de aço:

A posição da linha neutra e o momento de inércia da seção homogeneizada $I_{t r}$ são calculados diretamente através das expressões:

$$
\begin{gathered}
x=\frac{A_{a} z_{g}+\frac{b t_{c}{ }^{2}}{2 n}}{A_{a}+\frac{b t_{c}}{n}} \\
I_{t r}=I_{a}+A_{a}\left(z_{g}-x\right)^{2}+\frac{b t_{c}}{n}\left(\frac{t_{c}{ }^{2}}{12}+\left(x-\frac{t_{c}}{2}\right)^{2}\right)
\end{gathered}
$$

Os módulos de resistência elásticos da seção homogeneizada com relação à fibra inferior $\left(W_{t r}\right)_{i}$ e superior $\left(W_{t r}\right)_{s}$ são calculados conforme as expressões (3.17) e (3.18). 
Este caso ocorre quando a condição (3.19) não é satisfeita.

As tensões de cálculo são dadas por:

$$
\sigma_{s}=\frac{M_{s d}}{\left(W_{t r}\right)_{i}} \quad \sigma_{c}=\frac{M_{s d}}{n\left(W_{t r}\right)_{s}}
$$

No caso de interação parcial, a determinação das tensões é idêntica à feita para interação completa, devendo-se substituir apenas o valor de $\left(W_{t r}\right)_{i}$ por $W_{e f}$, conforme a expressão:

$W_{e f}=W_{a}+\sqrt{\frac{Q_{n}}{V_{h}}}\left[\left(W_{t r}\right)_{i}-W_{a}\right]$

onde

$W_{a}$ é o módulo de resistência elástico da viga de aço;

$V_{h}$ é o menor valor entre $A_{a} f_{y}$ e $0,85 b t_{c} f_{c k}$.

No caso de construção não escorada, além da verificação como viga mista, deve-se atender a duas exigências adicionais:

- Resistência de cálculo da viga de aço: A seção da viga de aço por si só deve ter resistência adequada para suportar todas as ações de cálculo aplicadas antes do concreto atingir uma resistência igual a $0,75 f_{c k}$;

- Limitação de tensões: Na mesa inferior da seção mais solicitada da viga, deve-se ter:

$$
\frac{M_{G}}{W_{a}}+\frac{M_{L}}{W_{e f}} \leq 0,90 f_{y}
$$


$M_{G}$ e $M_{L}$ são momentos fletores devido às ações nominais aplicadas, respectivamente, antes e depois da resistência do concreto atingir $0,75 f_{c k}$;

$W_{a}$ é o módulo elástico da seção da viga de aço;

$W_{\text {ef }}$ é o módulo elástico da seção efetiva, calculado conforme a equação (3.23).

Pode-se perceber pela expressão (3.24) que o histórico do carregamento assume uma importância maior no caso de construção não escorada.

As lajes devem ser adequadamente armadas para resistir a todas as solicitações de cálculo, a fim de controlar a fissuração em qualquer direção. A possibilidade de fissuração da laje, causada por cisalhamento, na região adjacente à viga de aço, paralelamente a esta, deve ser controlada pela colocação de armaduras adicionais transversais à viga. A referida armadura adicional deve ser colocada na face inferior da laje. A área da seção dessa armadura não pode ser inferior a $0,5 \%$ da área da seção de concreto, segundo um corte paralelo à viga, e deve ser usado espaçamento uniforme ao longo do vão.

A resistência à força cortante em vigas mistas deve ser determinada considerando-se apenas a resistência da viga de aço, não sendo aplicável o conceito de campo de tração, que está relacionado a reserva de resistência pós-flambagem da alma.

Com relação ao cálculo de deslocamentos, deve-se considerar o efeito de escorregamento (slip) no caso de interação parcial, onde o momento de inércia da seção homogeneizada é substituído por um momento de inércia efetivo $I_{e f}$, calculado conforme a expressão:

$$
I_{e f}=I_{a}+\sqrt{\frac{Q_{n}}{V_{h}}}\left[\left(I_{t r}\right)-I_{a}\right]
$$

onde

$I_{a}$ é o momento de inércia da viga de aço;

$I_{t r}$ é o momento de inércia da seção mista homogeneizada. 
Com respeito à construção não escorada, os deslocamentos devem ser obtidos considerando-se a superposição de dois casos: o carregamento atuante na viga de aço antes da cura do concreto e o carregamento atuante após a cura do concreto, considerando-se agora a seção mista.

\subsubsection{AISC-LRFD (1994)}

A norma americana é baseada no método dos Estados Limites e apresenta as mesmas condições e hipóteses de cálculo da NBR 8800, também fazendo distinção entre dois tipos de seções: "compactas" e "semi-esbeltas".

O momento fletor resistente é igual a $\phi_{b} M_{n}$, sendo $\phi_{b}$ o coeficiente de resistência e $M_{n}$ o momento nominal resistente. Tratando-se de seções "compactas", o momento nominal resistente é determinado assumindo-se plastificação total da seção mista. No caso de seções "semi-esbeltas", determina-se $M_{n}$ admitindo-se distribuição linear de tensões (análise elástica). O coeficiente $\phi_{b}$ assume os seguintes valores:

- $\phi_{b}=0,85$ para seções "compactas";

- $\phi_{b}=0,90$ para seções "semi-esbeltas" (o mesmo valor da NBR 8800).

Existe uma diferença com a norma brasileira em relação aos ajustes de coeficientes que multiplicam a resistência característica à compressão do concreto $\left(f_{c k}\right)$. A norma americana não faz ajustes de coeficientes, considerando, portanto, que a tensão no concreto é dada por $0,85 f_{c k}$, e não $0,66 f_{c k}$, conforme a NBR 8800 . Esse ajuste de coeficientes parecer ser mais razoável, uma vez que o coeficiente de ponderação da resistência do aço e do concreto são diferentes. $\mathrm{O}$ valor 0,66 é obtido por: $0,85 \times 1,1 / 1,4$, onde o coeficiente 0,85 corresponde ao efeito Rüsch e os valores 1,1 e 1,4 correspondem aos coeficientes de ponderação da resistência do aço e do concreto, respectivamente.

Em seções "semi-esbeltas", o dimensionamento também é baseado no processo elástico. No caso de interação completa, as propriedades da seção homogeneizada baseadas no processo elástico podem ser determinadas, segundo as 
expressões de (3.15) à (3.21). O coeficiente de homogeneização $n$ é igual a $E / E_{c}$, sendo $E$ = módulo de elasticidade do aço e $E_{c}=$ módulo de elasticidade do concreto, calculado pela seguinte expressão:

$E_{c}=42\left(\gamma_{c}\right)^{1,5} \sqrt{f_{c k}}$

onde

$\gamma_{c}$ é o peso específico do concreto $\left(\mathrm{em} \mathrm{kN} / \mathrm{m}^{3}\right)$;

$f_{c k}$ em MPa.

No caso de interação parcial, deve-se levar em conta o efeito da conexão parcial, conforme também recomenda a NBR 8800 , substituindo-se o valor $\left(W_{t r}\right)_{i}$ por $W_{e f}$, de acordo com a expressão (3.23).

No caso de construção não escorada, a viga de aço deve ter resistência suficiente para suportar os carregamentos a ela aplicados antes do concreto atingir $75 \%$ de sua resistência característica $f_{c k}$. Os deslocamentos também devem ser considerados durante o processo construtivo.

No cálculo de deslocamentos, efetuado no regime elástico, utiliza-se um momento de inércia efetivo aproximado $I_{e f}$, conforme a expressão a expressão (3.25), utilizada também pela NBR 8800 .

A norma americana cita que as equações (3.23) e (3.25) não devem ser utilizadas para relações $Q_{n} / V_{h}$ menores que 0,25 .

\subsubsection{CAN/CSA - S16.1 (1994)}

A norma canadense é baseada no método dos estados limites, e utiliza os mesmos procedimentos de cálculo da norma americana. Os coeficientes de resistência para os dois materiais são:

$\phi_{\mathrm{a}}=0,90$ para o aço;

$\phi_{c}=0,60$ para o concreto.

A interação será completa se: 
$Q_{n} \geq \phi_{a} A_{a} f_{y}$ ou $Q_{n} \geq \phi_{c} 0,85 f_{c k} b t_{c}$

onde:

$Q_{n}=\sum \phi_{s c} q_{n}$, ou seja, o somatório das resistências individuais de cálculo $\phi_{s c} q_{n} \operatorname{dos}$ conectores situados entre a seção de momento máximo e a seção adjacente de momento nulo; $\phi_{s c}$ é o coeficiente de resistência para conectores de cisalhamento, igual a 0,80 .

Se a condição (3.27) não for atendida, então a interação será parcial.

Assim, os momentos resistentes de cálculo podem ser determinados da mesma forma que a norma americana LRFD, substituindo-se o coeficiente $\phi_{b}$ pelos coeficientes da norma canadense $\phi, \phi_{c}, \phi_{s c}$ aplicados convenientemente para os respectivos materiais.

O grau de conexão mínimo deve ser igual a 0,4 na verificação da resistência ao momento fletor da viga mista. Na determinação de deslocamentos, o grau de conexão mínimo deve ser igual a 0,25 .

Ainda sobre deslocamentos, esta norma cita que devem ser considerados os efeitos da fluência e retração do concreto, bem como o efeito de escorregamento (slip) ao nível da ligação aço-concreto.

O efeito de escorregamento é considerado por meio de um momento de inércia efetivo, dado por:

$I_{e f}=I_{a}+0.85 p^{0,25}\left(I_{t r}-I_{a}\right)$

onde

$p=Q_{n} / V_{h}$ ( $p$ é igual a 1,0 no caso de interação completa e $V_{h}$ é o menor dos seguintes valores: $\phi A_{a} f_{y}$ e $\left.\phi_{c} 0,85 f_{c k} b t_{c}\right)$;

$I_{a}$ é o momento de inércia da viga de aço;

$I_{t r}$ é o momento de inércia da seção mista homogeneizada. 
Os valores de momento de inércia efetivo calculados com a expressão (3.28) são muitos próximos aos obtidos com a expressão (3.25), a qual é apresentada pela norma brasileira e a norma americana.

O efeito da fluência é considerado por meio de uma redução de até $15 \%$ no valor do momento de inércia efetivo, calculado conforme a expressão (3.28).

O deslocamento vertical $\Delta s$, devido ao efeito da retração, considerando uma viga simplesmente apoiada, é calculado através da adoção de um valor para a deformação por retração livre. Esse deslocamento é expresso por:

$$
\Delta s=\frac{\varepsilon_{f} A_{c} L^{2}}{8 n_{t} I_{t r}} y
$$

onde

$y$ é a distância da linha neutra elástica até o ponto de aplicação da resultante de compressão na laje

$\varepsilon_{f}$ é a deformação proveniente da retração livre. Esta deformação depende das características do concreto, tais como relação água/cimento, umidade relativa, condições de cura, etc. $\mathrm{O}$ valor de $800 \times 10^{-6}$ pode ser adotado para $\varepsilon_{f}$ caso não se tenha informações disponíveis (conforme ACI 209R-92);

$A_{c}$ é a área efetiva da laje de concreto;

$L$ é o vão da viga mista;

$n_{t}=E / E_{c t}$, ou seja, a relação entre o módulo de elasticidade do aço e o módulo de elasticidade do concreto à tração. $\mathrm{O}$ valor de $E_{c t}$ pode ser obtido aproximadamente através da expressão proposta por SHAKER \& KENNEDY (1983), para concretos $\operatorname{com} f_{c k}$ entre 30 e $40 \mathrm{MPa}$ :

$E_{c t}=8300-4800 \sigma_{c t} \quad, \quad 0,3 \leq \sigma_{c t} \leq 1,2 \mathrm{MPa}$

onde

$\sigma_{\mathrm{ct}}$ é a tensão de tração no concreto $(\mathrm{MPa})$. 
As verificações necessárias no caso construção não escoradas são as mesmas da norma americana AISC-LRDF (1994).

\subsubsection{EUROCODE 4: PARTE 1.1 (1992)}

O momento fletor resistente de cálculo pode ser determinado admitindo-se a plastificação total para seções da classe 1 ou da classe 2. Para as seções das classes 3 e 4, entretanto, deve-se utilizar o cálculo elástico (distribuição linear de tensões).

Os métodos de cálculo apoiam-se nas seguintes hipóteses:

- A resistência à tração do concreto é desprezada;

- As seções dos elementos de aço e do concreto da viga mista permanecem planas.

Para a análise plástica das seções, considera-se que:

- A tensão de cálculo na viga de aço é igual a $f_{y} / \gamma_{a}$, tanto para a tração quanto para a compressão, onde $\gamma_{a}$ é o coeficiente de resistência do aço do perfil;

- A área efetiva de concreto na zona comprimida resiste a uma tensão de cálculo igual a $0,85 f_{c k} / \gamma_{c}$, constante em toda a altura entre a linha neutra plástica e a fibra de concreto mais comprimida, onde $\gamma_{c}$ é o coeficiente de resistência do concreto;

- As armaduras longitudinais resistem a uma tensão de cálculo igual a $f_{s y} / \gamma_{s}$ tanto para tração quanto para compressão, onde $f_{s y}$ e $\gamma_{s}$ são a resistência ao escoamento e o coeficiente de resistência, respectivamente, do aço da armadura. Como alternativa, pode-se desprezar a contribuição da armadura comprimida.

A figura 3.8 ilustra a distribuição de tensões ao longo da seção transversal da viga mista para as três possíveis posições da linha neutra plástica (L.N.P.), no caso 
de interação completa. A figura 3.9 ilustra a distribuição de tensões no caso de interação parcial.

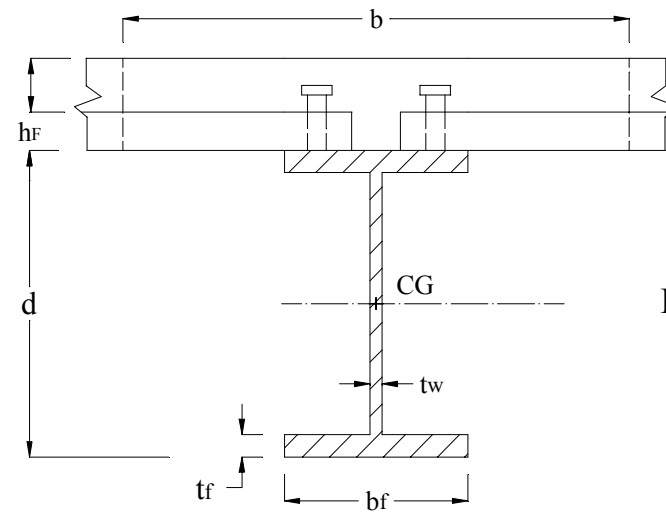

a)

Seção

Transversal

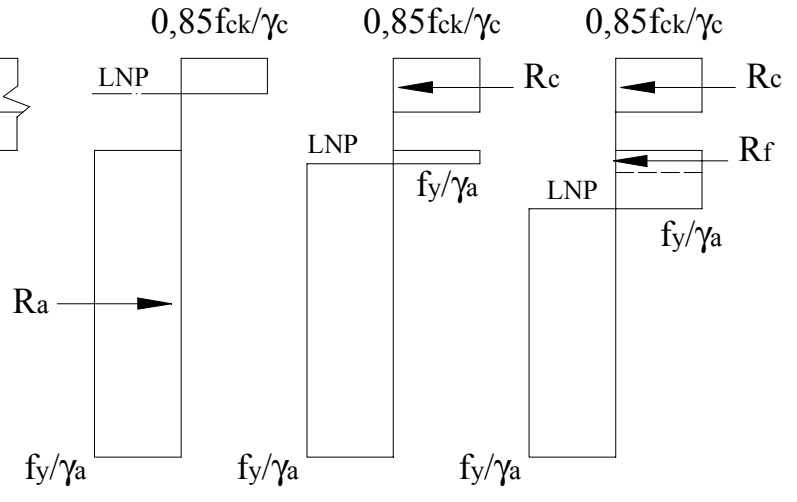

b) d)

FIGURA 3.8: Distribuição de tensões em vigas mistas sob momento positivo Interação completa

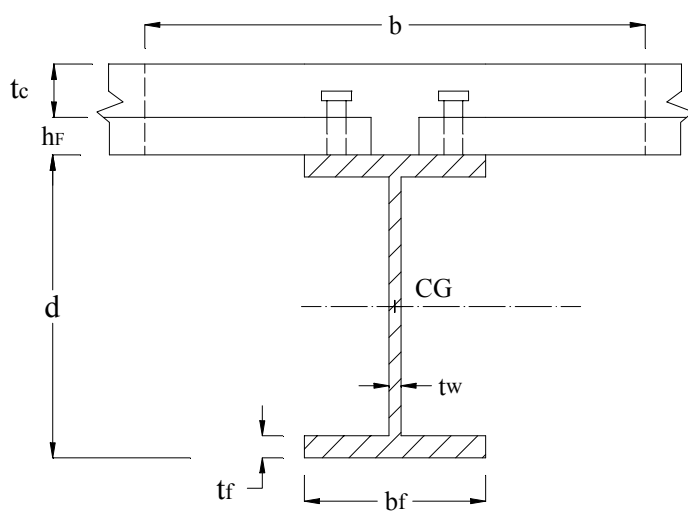

a)

Seção

Transversal

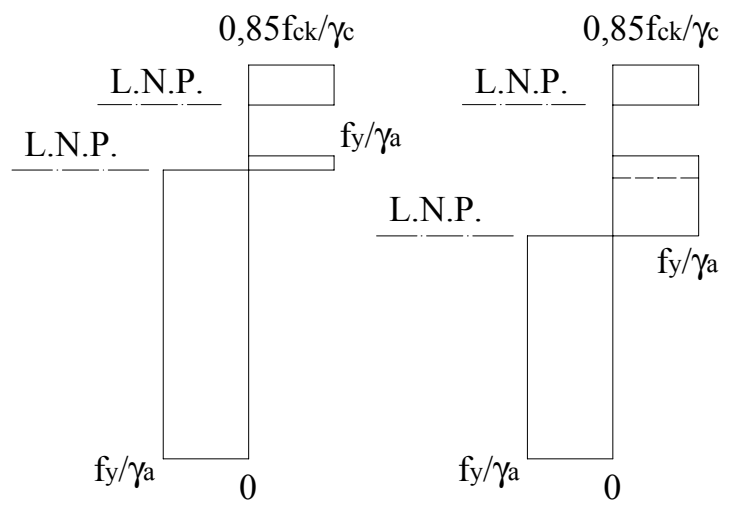

b)

c)

L.N.P. na mesa superior
L.N.P. na alma

FIGURA 3.9: Distribuição de tensões em vigas mistas sob momento positivo Interação parcial

Os coeficientes de resistência são apresentados na tabela 3.2. 
TABELA 3.2 : Valores dos coeficientes de resistência segundo o EUROCODE 4.

\begin{tabular}{||l|c|c|c|c||}
\hline \multicolumn{1}{|c|}{ Material } & $\begin{array}{c}\text { Aço } \\
\text { (perfil) }\end{array}$ & $\begin{array}{c}\text { Aço } \\
\text { (armadura) }\end{array}$ & Conectores & Concreto \\
\hline Simbologia & $\gamma_{\mathrm{a}}$ & $\gamma_{\mathrm{s}}$ & $\gamma_{\mathrm{v}}$ & $\gamma_{\mathrm{c}}$ \\
\hline Estado limite último & 1,10 & 1,15 & 1,25 & 1,5 \\
\hline
\end{tabular}

A seguir são apresentadas as forças utilizadas na determinação do momento resistente da seção mista formada por viga de aço duplamente simétrica.

$$
\begin{aligned}
& R_{c}=\frac{0,85 f_{c k} b t_{c}}{\gamma_{c}} \\
& R_{f}=\frac{b_{f} t_{f} f_{y}}{\gamma_{a}} \\
& R_{a}=\frac{A_{a} f_{y}}{\gamma_{a}} \\
& R_{w}=\frac{h_{w} t_{w} f_{y}}{\gamma_{a}} \\
& R_{q}=N q_{R d}
\end{aligned}
$$

onde

$N$ é o número de conectores entre a seção de momento máximo e a seção de momento nulo;

$q_{R d}$ é a resistência individual de cálculo do conector;

$\gamma_{c}$ e $\gamma_{a}$ são os coeficientes de resistência do concreto e do aço, respectivamente.

a) Interação completa - Linha Neutra Plástica na Laje $\left(R_{c} \geq R_{a}\right)$

Logo, o momento resistente $M_{R d}$ é dado por:

$$
M_{R d}=R_{a}\left(\frac{d}{2}+t_{c}+h_{F}-\frac{R_{a}}{R_{c}} \frac{t_{c}}{2}\right)
$$


b) Interação Completa - Linha Neutra Plástica na viga de aço $\left(R_{a}>R_{c}\right)$

b.1) Linha Neutra Plástica na mesa superior

Ocorre quando $R_{c} \geq R_{a}-2 R_{f}$

O momento fletor resistente é dado por:

$M_{R d}=R_{a} \frac{d}{2}+R_{c} \frac{\left(t_{c}+2 h_{F}\right)}{2}-\frac{\left(R_{a}-R_{c}\right)^{2}}{R_{f}} \frac{t_{f}}{4}$

\section{b.2) Linha Neutra Plástica na alma}

Ocorre para $R_{c}<R_{a}-2 R_{f}$

O momento fletor resistente é dado por:

$M_{R d}=\left(M_{R d}\right)_{a}+R_{c} \frac{\left(d+t_{c}+2 h_{F}\right)}{2}-\frac{R_{c}^{2}}{R_{w}} \frac{t_{w}}{4}$

onde

$\left(M_{R d}\right)_{a}$ é o momento resistente de cálculo da viga de aço isolada.

c) Interação Parcial:

Deve-se admitir interação parcial apenas para as seções que pertençam às classes 1 ou 2. É importante lembrar a definição de grau de conexão $g$, cujo valor é calculado por:

$g=\frac{Q_{R d}}{V_{h}}$

onde 
$Q_{R d}$ é o somatório das resistências de cálculo individuais dos conectores, ou seja, $Q_{R d}=\sum_{N} q_{R d}$

$V_{h}$ é o menor valor entre $\frac{A_{a} f_{y}}{\gamma_{a}}$ e $b t_{c} 0,85 \frac{f_{c k}}{\gamma_{a}}$.

O valor de $g=1$ é o limite entre a interação parcial e a interação total. Valores de $g$ menores que a unidade indicam interação parcial, enquanto que maiores indicam interação total.

O momento resistente de cálculo de uma viga mista calculada para a interação parcial pode ser determinado por um dos seguintes métodos:

- Método do Equilíbrio

- Método da Interpolação Linear

Método do Equilíbrio:

Neste método, a força transmitida ao concreto é determinada pela resistência dos conectores de cisalhamento. As equações de equilíbrio, que dão origem à curva $\mathrm{ABC}$ na figura 3.10, podem ser determinadas utilizando a teoria no regime plástico.

Quando a segunda linha neutra plástica encontra-se na mesa superior $\left(R_{q} \geq\right.$ $\left.R_{a}-2 R_{f}\right)$, calcula-se o momento resistente $\left(M_{R d}\right)_{p}$ pela seguinte expressão:

$$
\left(M_{R d}\right)_{p}=R_{a} \frac{d}{2}+R_{q}\left\{t_{c}+h_{F}-\frac{R_{q}}{R_{c}} \frac{t_{c}}{2}\right\}-\frac{\left(R_{a}-R_{q}\right)^{2}}{R_{f}} \frac{t_{f}}{4}
$$

Se a linha neutra estiver na alma da viga $\left(R_{q}<R_{a}-2 R_{f}\right)$, o momento resistente de cálculo é então expresso por:

$$
\left(M_{R d}\right)_{p}=\left(M_{R d}\right)_{a}+R_{q}\left\{\frac{d}{2}+t_{c}+h_{F}-\frac{R_{q}}{R_{c}} \frac{t_{c}}{2}\right\}-\frac{R_{q}^{2}}{R_{w}} \frac{h_{w}}{4}
$$


Método da Interpolação Linear:

Este método é mais conservador, porém bastante utilizado devido a sua simplicidade. A curva $\mathrm{ABC}$ mostra a variação típica da relação entre o momento resistente na interação parcial e o momento resistente na interação completa com grau de conexão $g$, utilizando o método do equilíbrio. No método da interpolação, por simplificação, representa-se a curva $\mathrm{ABC}$ por uma reta, conforme a figura.3.9:

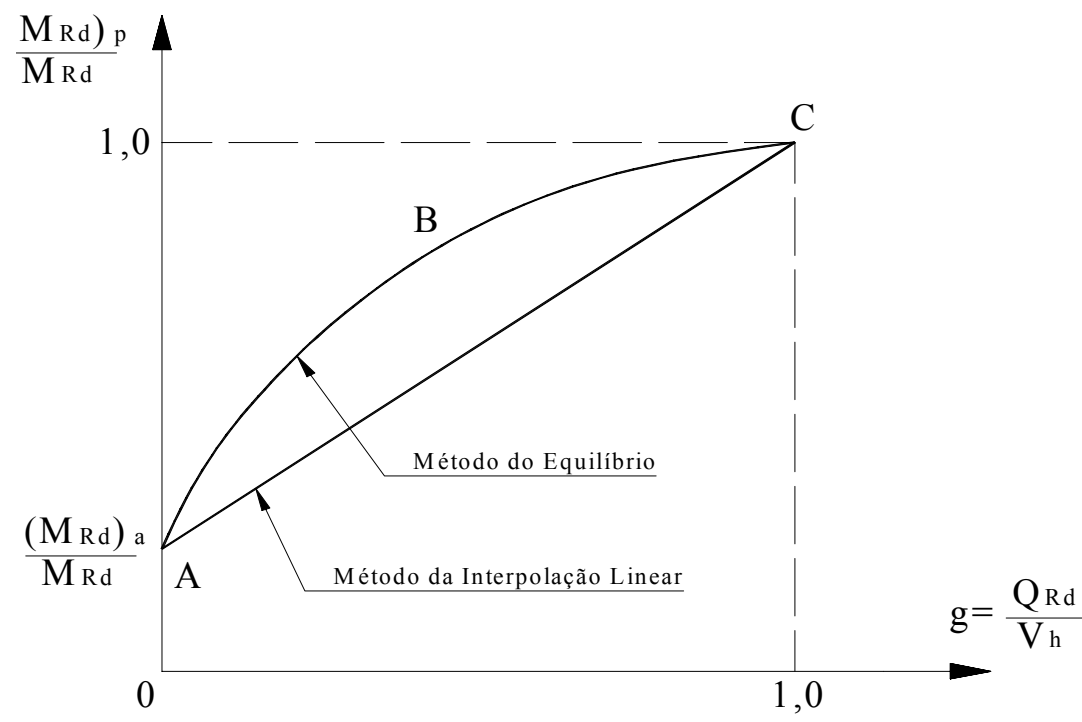

FIGURA 3.10: Métodos de cálculo para interação parcial - EUROCODE 4.

Assim, o momento resistente de cálculo para a interação parcial $\left(M_{R d}\right)_{p}$ pode ser expresso por:

$\left(M_{R d}\right)_{p}=\left(M_{R d}\right)_{a}+\left\{M_{R d}-\left(M_{R d}\right)_{a}\right\} \frac{Q_{n}}{V_{h}}$

onde

$\left(M_{R d}\right)_{a}$ é o momento resistente de cálculo da viga de aço isolada;

$M_{R d}$ é o momento resistente da seção mista para interação completa, conforme já definido anteriormente.

No caso de construção não escorada, a resistência ao momento fletor da seção mista é determinada utilizando o cálculo elástico, sendo expressa por: 


$$
M_{R d}=\frac{\left(M_{s d}\right)_{a}-\left(M_{s d}\right)}{r}
$$

onde

$\left(M_{s d}\right)_{a}$ é o momento fletor solicitante de cálculo na viga de aço decorrente das ações atuantes sobre esta;

$M_{s d}$ é o momento fletor solicitante de cálculo na viga mista decorrente das ações atuantes sobre esta;

$r$ é a maior relação entre a tensão total (soma das ações na viga de aço e na viga mista) e a tensão máxima permitida em cada material na verificação da resistência ao momento fletor no regime elástico.

A norma apresenta algumas definições e restrições com relação ao número e distribuição dos conectores.

As seções "críticas", relevantes na distribuição dos conectores, são definidas como sendo:

- seções de momento fletor máximo;

- apoios;

- seções em que atuam forças concentradas elevadas;

- seções onde exista uma variação brusca da seção transversal da viga.

No caso de interação total, o número necessário de conectores entre seções críticas é igual a:

$$
N=\frac{V_{h}}{q_{R d}}
$$

onde

$V_{h}$ é o menor dos seguintes valores: $\frac{A_{a} f_{y}}{\gamma_{a}}$ e $\frac{0,85 b t_{c} f_{c k}}{\gamma_{a}}+\frac{A_{s} f_{s y}}{\gamma_{s}}$, sendo $A_{s}$ a área de qualquer armadura longitudinal comprimida que for eventualmente incluída no 
cálculo da resistência ao momento fletor e $f_{s y}$ a resistência ao escoamento do aço da armadura. Como alternativa, a armadura longitudinal comprimida pode ser desprezada.

No caso de interação parcial, o número de conectores necessários entre seções críticas é igual a:

$$
N=\frac{F_{c}}{q_{R d}}
$$

onde

$q_{R d}$ é a resistência de cálculo do conector;

$F_{c}$ é a força de compressão na laje necessária para resistir ao momento fletor solicitante de cálculo $M_{s d}$. Um valor mais conservador, porém mais prático, é obtido utilizando-se o método da Interpolação Linear, conforme já descrito neste item. $\mathrm{O}$ valor de $F_{c}$ é expresso por:

$F_{c}=\left\{\frac{M_{S d}-\left(M_{R d}\right)_{a}}{M_{R d}-\left(M_{R d}\right)_{a}}\right\} V_{h}$

onde

$\left(M_{R d}\right)_{a}$ e $M_{R d}$ são definidos conforme a expressão (3.42). Notar que a relação $F_{c} / V_{h}$ constitui o grau de conexão $g$.

Esta norma apresenta algumas limitações no valor do grau de conexão, as quais serão apresentadas a seguir:

- Para as vigas de aço duplamente simétricas, os conectores do tipo pino com cabeça de diâmetro entre 16 a $22 \mathrm{~mm}$ podem ser considerados "dúcteis" se estiverem dentro de certos limites, segundo o grau de conexão $g$ :

$$
\text { Para } \mathrm{L} \leq 5 \mathrm{~m} \quad g=\frac{Q_{R d}}{V_{h}} \geq 0,4
$$




$$
\begin{array}{ll}
\text { Para } 5 \leq \mathrm{L} \leq 25 \mathrm{~m} & g=\frac{Q_{R d}}{V_{h}} \geq 0,25+0,03 L \\
\text { Para } \mathrm{L}>25 \mathrm{~m} & g=\frac{Q_{R d}}{V_{h}} \geq 1,0
\end{array}
$$

- Em vigas de aço cuja área da mesa inferior seja até três vezes maior que a área da mesa superior:

$$
\begin{aligned}
& \text { Para } \mathrm{L} \leq 20 \mathrm{~m} \\
& \text { Para } \mathrm{L}>20 \mathrm{~m} \quad g=\frac{Q_{R d}}{V_{h}} \geq 0,4+0.03 L \\
& \text { onde } \\
& L \text { é o vão da viga mista em metros. }
\end{aligned}
$$

Nota-se que, para vãos usuais de edifícios (de 7 à $12 \mathrm{~m}$ ), o limite para o grau de conexão está compreendido entre 0,45 e 0,60. Estes valores são próximos dos estabelecidos pela norma britânica, americana, canadense e brasileira.

Com relação à distribuição dos conectores, estes podem ser espaçados uniformemente em um comprimento $L_{c r}$ - distância entre seções críticas adjacentes sempre que:

- Todas as seções críticas do vão considerado pertençam à classe 1 ou 2;

- O grau de conexão $g$ satisfaça os limites apresentados na condição de consideração dos conectores como "dúcteis", quando $L$ é substituído por $L_{c r}$

- O momento resistente da viga mista seja maior que 2,5 vezes o momento resistente da viga de aço isolada. Neste caso deve-se fazer verificações adicionais sobre a suficiência da ligação nos pontos médios entre seções críticas.

O efeito da fluência é considerado através de um coeficiente de homogeneização, definido por $n=E / E_{c}$ '. Para carregamentos de longa duração, $E_{c}$ ' 
pode ser tomado igual a $E_{c} / 3$ em edifícios submetidos a grandes cargas de armazenamento e igual a $E_{c} / 2$ nos demais casos.

As flechas no elemento misto devem ser calculadas considerando-se o comportamento elástico. Quando se trata de interação parcial, o acréscimo de deslocamento devido ao efeito do escorregamento depende do método construtivo. A flecha total $\delta$ é calculada pela seguinte expressão:

$\delta=\delta_{c}\left\{1+K\left(1-\frac{Q_{R d}}{V_{h}}\right)\left(\frac{\delta_{a}}{\delta_{c}}-1\right)\right\}$

onde

$K$ é igual a 0,5 para construção escorada e 0,3 para construção não escorada;

$\delta_{c}$ é a flecha da viga mista, considerando interação completa;

$\delta_{a}$ é a flecha da viga de aço atuando isoladamente.

Esse acréscimo no deslocamento vertical pode ser ignorado no caso de construção não escorada quando:

- $\frac{Q_{R d}}{V_{h}} \geq 0,5$ ou quando os esforços nos conectores não superem $70 \%$ da sua resistência nominal;

- Em lajes de fôrma de aço incorporada e nervuras perpendiculares à viga, desde que a altura das nervuras não seja maior que $80 \mathrm{~mm}$.

Com relação aos efeitos da retração, estes podem ser desprezados nas verificações associadas ao estado limite último em estruturas mistas de edificações, exceto em verificações no regime elástico de elementos com seções pertencentes à classe 4. Em casos usuais, pode-se assumir a deformação por retração $\varepsilon_{c s}$ igual aos seguintes valores aproximados:

- Em ambiente seco (dentro ou fora de edifícios, exceto elementos preenchidos com concreto): $\varepsilon_{c s}=325 \times 10^{-6}$ para concretos de densidade normal e $\varepsilon_{c s}$ $=500 \times 10^{-6}$ para concretos de baixa densidade; 
- Em outros ambientes e em elementos preenchidos com concreto: $\varepsilon_{c s}=200 \mathrm{x}$ $10^{-6}$ para concretos de densidade normal e $\varepsilon_{c s}=300 \times 10^{-6}$ para concretos de baixa densidade.

Em regime de utilização, os efeitos da retração devem ser considerados para vigas cujas relações vão/altura sejam maiores que 20 e quando a deformação por retração livre for maior que $400 \times 10^{-6}$. Em vigas usuais de edifícios, o efeito da retração nos deslocamentos não é significativo.

\section{Interação completa para as seções da classe 3 e 4 - Análise Elástica}

A resistência ao momento fletor positivo de uma viga mista cuja seção pertença à classe 3 ou 4 é geralmente governada pela máxima tensão na viga de aço, calculada pelo processo elástico. A análise elástica é feita com base nas propriedades da seção mista homogeneizada. Para a obtenção da seção homogeneizada, divide-se a largura efetiva da laje por $n=E / E_{c}$ ', onde $E$ é o módulo de elasticidade do aço e $E_{c}$ ' é o módulo de elasticidade "efetivo" do concreto, levando-se em conta o efeito da fluência. Para carregamentos de curta duração, $E_{c}{ }^{\prime}=E_{c}$, sendo $E_{c}=$ módulo de elasticidade do concreto. Para carregamentos de longa duração, $E_{c}{ }^{\prime}=E_{c} / 3$.

As propriedades da seção homogeneizada podem ser determinadas pelas expressões de (3.15) à (3.21), conforme o item 3.3.1.1.

É usual desprezar a armadura negativa e a zona tracionada da laje de concreto. Também é usual desconsiderar o concreto situado entre nervuras, em lajes com fôrma de aço incorporada.

$\mathrm{Na}$ análise elástica, as tensões provocadas pelo momento solicitante de cálculo $M_{s d}$ devem ser limitadas pelas seguintes tensões:

- $0,85 f_{c k} / \gamma_{c}$ para o concreto comprimido;

- $f_{y} / \gamma_{a}$ para a zona tracionada na viga de aço, em seções das classes 3 e 4 e, para a zona comprimida, em seções da classe 3 ; 
- $f_{y} / \gamma_{R d}$ para a zona comprimida na viga de aço em seções da classe 4 , onde $\gamma_{R d}=1,0$.

\subsubsection{BS 5950 : PARTE 3 (1990)}

A determinação do momento fletor resistente de cálculo é baseada nas mesmas hipóteses do EUROCODE 4, fazendo-se distinção em quatro tipos de seções: super compacta, compacta, semi-compacta e esbelta.

Com respeito à análise plástica, considera-se que:

- A tensão de cálculo no concreto é constante e igual a $0,45 f_{c k}$ em toda a zona comprimida, ou seja, em toda a altura acima da linha neutra plástica;

- A tensão de cálculo na viga de aço é igual a $f_{y}$, tanto para a zona tracionada quanto para a comprimida;

- As armaduras longitudinais resistem a uma tensão de cálculo igual a $0,87 f_{s y}$, tanto para tração quanto para compressão.

O coeficiente 0,45 que multiplica o valor de $f_{c k}$ é um valor implícito, no qual já estão embutidos os coeficientes de ponderação da resistência dos materiais e as simplificações adotadas pela norma.

A determinação da resistência ao momento fletor utilizando a análise plástica é aplicada apenas para as seções cuja mesa comprimida pertençam às classes 1 ou 2 . Para as seções com mesa comprimida na classe 3 ou 4 ou alma na classe 4, deve-se utilizar a análise elástica.

Com respeito à análise elástica, considera-se uma distribuição linear de deformações na seção homogeneizada, porém limitando-se as tensões em: 
- $0,50 f_{c k}$ no concreto comprimido, assumindo-se uma distribuição retangular de tensões. Caso se considere uma distribuição parabólica-retangular, limita-se a tensão em $0,45 f_{c k}$ e o encurtamento da fibra mais comprimida em 0,0035 ;

- $f_{v}$ na viga de aço, que corresponde a uma tensão reduzida conforme recomenda a BS 5950 (1990): Parte 1, em seções pertencentes à classe 4;

- $\quad 0,87 f_{s y}$ na armadura longitudinal, tanto comprimida quanto tracionada.

Para a determinação das propriedades da seção mista homogeneizada, utilizase o coeficiente de homogeneização efetivo $\alpha_{e}$, calculado pela expressão:

$\alpha_{e}=\alpha_{s}+\rho_{l}\left(\alpha_{l}-\alpha_{s}\right)$

onde

$\alpha_{l}$ é o coeficiente de homogeneização para ações de longa duração;

$\alpha_{s}$ é o coeficiente de homogeneização para ações de curta duração;

$\rho_{l}$ é a razão entre as ações de longa duração e a ação total.

A tabela 3.3 contém os valores de $\alpha_{e}$ para ações de curta e longa duração e, também, os valores usuais utilizados em projetos de edifícios. Estes valores são aplicáveis para todas as classes de concreto.

TABELA 3.3 : Valores do coeficiente de homogeneização efetivo $\alpha_{e}$

\begin{tabular}{|c|c|c|c|}
\hline TIPO DE CONCRETO & $\begin{array}{c}A C ̧ \tilde{O} E S \text { DE CURTA } \\
\text { DURAÇÃO }\end{array}$ & $\begin{array}{c}A C ̧ \tilde{O} E S \text { DE LONGA } \\
\text { DURAÇÃO }\end{array}$ & USUAL \\
\hline Densidade normal & 6 & 16 & 10 \\
\hline Baixa densidade & 10 & 25 & 15 \\
\hline
\end{tabular}

Obs. : O concreto de baixa densidade possui um peso próprio menor em relação ao concreto de densidade normal (entre 17 e $18 \mathrm{kN} / \mathrm{m}^{3}$ ). No entanto a resistência à compressão entre os dois tipos são similares. A BS 8110 apresenta maiores detalhes quanto à limitação das classes e do peso próprio aplicáveis ao concreto de baixa densidade e de densidade normal. 
A seguir, são apresentadas as forças resistentes nos vários elementos da viga e a nomenclatura utilizada nas expressões :

$$
\begin{aligned}
& R_{c}=0,45 f_{c k} b t_{c} \\
& R_{f}=b_{f} t_{f} f_{y} \\
& R_{o}=38 \varepsilon t_{w}^{2} f_{y} \\
& R_{q}=N q_{R d} \\
& R_{a}=A_{a} f_{y} \\
& R_{w}=h_{w} t_{w} f_{y}
\end{aligned}
$$

onde

$N$ é o número de conectores entre a seção de momento máximo e a seção de momento nulo;

$q_{R d}$ é a resistência de cálculo do conector de cisalhamento;

$\varepsilon$ é uma constante igual a $\sqrt{\frac{275}{f_{y}}}, \operatorname{com} f_{y}$ em MPa.

O momento resistente de cálculo em vigas mistas compostas por perfis duplamente simétricos é determinado conforme as expressões apresentadas no item 3.3.1.4 para o EUROCODE 4, devendo-se apenas substituir as forças resistentes dos elementos da viga.

Quando a alma da viga de aço pertence à classe 3 ou 4, obtém-se o momento resistente de cálculo considerando-se duas possíveis situações:

\section{1) Linha Neutra Elástica na alma - Interação Completa}

Ocorre para $R_{c}<R_{a}-2 R_{f}$ 
Como $\frac{h_{h}}{t_{w}}>\frac{76 \varepsilon}{1-\frac{R_{c}}{R_{w}}}$ (alma na classe 3 ou 4$)$, então:

$$
M_{R d}=\left(M_{R d}\right)_{a}+R_{c} \frac{\left(d+t_{c}+2 h_{F}\right)}{2}-\frac{R_{c}^{2}+\left(R_{w}-R_{c}\right)\left(R_{w}-R_{c}-2 R_{o}\right)}{R_{w}} \frac{h_{w}}{4}
$$

onde

$\left(M_{R d}\right)_{a}$ é o momento resistente de cálculo da viga de aço isolada (plastificação total).

2) Linha Neutra Elástica na alma - Interação Parcial

Ocorre quando $R_{q}<R_{a}-2 R_{f}$ e $\frac{h_{w}}{t_{w}}>76 \varepsilon$ (alma na classe 3 ou 4). Logo, o momento resistente é dado por :

$$
M_{R d}=\left(M_{R d}\right)_{a}+R_{q}\left\{\frac{d}{2}+t_{c}+h_{F}-\frac{R_{q}}{R_{c}} \frac{t_{c}}{2}\right\}-\frac{R_{q}^{2}+\left(R_{w}-R_{q}\right)\left(R_{w}-R_{q}-2 R_{o}\right)}{R_{w}} \frac{h_{w}}{4}
$$

Com relação ao número de conectores, no caso de interação total, o número necessário de conectores entre a seção de momento máximo e a seção adjacente de momento nulo é igual a :

$$
N=\frac{V_{h}}{q_{R d}}
$$

onde

$V_{h}$ é o menor valor entre $A_{a} f_{y}$ e $0,45 f_{c k} b t_{c}$;

$q_{R d}$ é a resistência de cálculo do conector, conforme o item 2.2.

No caso de interação parcial, o número de conectores deve atender à seguinte condição, no que se refere ao grau de conexão $g$ : 
$g=\frac{\sum q_{R d}}{V_{h}} \geq \frac{L-6}{10} \quad$ com $g \geq 0,4$

Segundo esta limitação, vigas mistas com vãos maiores que $16 \mathrm{~m}$ devem ser projetadas com interação total enquanto que, vigas mistas com vãos menores que 10 m não devem apresentar grau de conexão menor que 0,4 .

As recomendações sobre o espaçamento e distribuição de conectores são similares às apresentadas pelo EUROCODE 4. Os conectores podem ser uniformemente espaçados entre a seção de momento máximo e a seção adjacente de momento nulo, realizando-se sempre verificações adicionais da ligação nos seguintes casos:

a) Em seções de carga concentrada elevada : Segundo a norma britânica, uma carga concentrada é considerada elevada quando o momento fletor devido a esta carga, para uma viga simplesmente apoiada de mesmo vão, supera $10 \%$ do momento resistente da viga mista;

b) Em seções onde ocorre uma mudança brusca na seção transversal ;

c) Quando o elemento misto apresenta uma variação linear na seção transversal : devem ser feitas verificações em uma série de pontos intermediários, de modo que a relação entre o maior e menor momento resistente entre seções distintas não exceda 2,5 ;

d) Quando a mesa de concreto é excessivamente larga : quando o momento resistente da viga mista for maior que 2,5 vezes o momento resistente da viga de aço isolada, devem-se fazer verificações adicionais nos pontos médios entre as seções de momento máximo e de momento nulo.

A verificação de deslocamentos depende do método construtivo. No caso de construção não escorada, deve-se verificar, além da seção mista, a viga de aço isolada com o carregamento devido ao peso próprio do concreto. No caso de construção escorada, os deslocamentos devem ser verificados com base nas propriedades da seção mista homogeneizada. O cálculo dos deslocamentos deve ser feito utilizando-se a teoria elástico-linear. 
No caso de interação parcial, a flecha total em regime de utilização é determinada conforme o EUROCODE 4, com a diferença que a norma britânica não apresenta condições para que o acréscimo no deslocamento vertical seja ignorado. 


\subsubsection{RESISTENNCIA AO MOMENTO FLETOR : REGIÃO DE MOMENTOS NEGATIVOS}

\subsubsection{INTRODUÇÃO: VIGAS CONTÍNUAS}

Conforme JOHNSON (1994), as principais vantagens das vigas mistas contínuas em relação às simplesmente apoiadas, para um determinado tipo de laje e de carregamento, por unidade de comprimento da viga, são:

- A possibilidade de se utilizar maiores relações de vão/altura para uma dada flecha admissível;

- A estrutura do pavimento como um todo é menos susceptível ao efeito da vibração causado pelo movimento de pessoas.

As duas vantagens citadas estão associadas ao ganho de rigidez global da estrutura, favorecido pelas conexões viga/coluna. DISSANAYAKE \& BURGESS (1998) mostraram, através de um estudo que teve como objetivo avaliar a influência do tipo de conexão viga/coluna no comportamento de vigas mistas em pórticos, que existe uma redução significativa dos deslocamentos quando se considera as vigas mistas como parte do pórtico, ao invés de considerá-las como elementos isolados e simplesmente apoiados.

Por outro lado, a existência de regiões de momentos negativos causam uma perda na eficiência do sistema misto, pois além de diminuírem a resistência à flexão provocada pela fissuração do concreto tracionado, sujeitam a zona comprimida à flambagem local ou à instabilidade por distorção da viga de aço. Além disso, os procedimentos de cálculo são mais complexos quando comparados com o caso de vigas simplesmente apoiadas. Não é possível avaliar tensões e deformações com precisão, pois além do efeito da fissuração, existem os efeitos da fluência e da retração. Nos apoios, ocorrem tensões de tração consideráveis no concreto. Isto é influenciado pela seqüência de construção da laje, pelo método de escoramento 
utilizado e pelos efeitos da temperatura, retração e escorregamento ao nível da ligação.

Existe uma diferença significativa na rigidez à flexão de uma viga mista completamente fissurada e outra sem fissuração, o que leva a incertezas quanto à distribuição de momentos fletores ao longo da viga. Por esse motivo, e também por economia, a análise plástica deve ser utilizada sempre que possível, ao invés da análise elástica, pois esta última superestima os momentos nos apoios devido ao fato da fissuração reduzir a rigidez à flexão da seção.

\subsubsection{FATORES QUE INFLUENCIAM A RESISTENCIA AO MOMENTO FLETOR EM VIGAS CONTÍNUAS SOB MOMENTOS NEGATIVOS}

A resistência ao momento fletor de vigas mistas submetidas a momento positivo é governada pela resistência do concreto e da viga de aço, e um cálculo simples, baseado na plastificação total da seção fornece, com notável precisão, o momento resistente. Nas regiões de momento negativo, entretanto, pode ocorrer a instabilidade local e a instabilidade por distorção da viga de aço, visto que a zona comprimida da viga não é diretamente restringida pela laje de concreto. A fissuração do concreto normalmente ocorre para níveis de carregamento baixos (correspondentes a $30 \%$ do momento resistente da viga), influenciando também a capacidade da seção quanto à redistribuição dos momentos fletores.

DEKKER et al. (1995) apresentam e discutem os fatores que influenciam o comportamento de vigas mistas sob momento fletor negativo, relacionando-os com a geometria da seção e a relação entre os vãos. Propuseram um modelo teórico que fornece uma base para a avaliação da influência da restrição à torção, oferecida pela laje à viga de aço. Os modelos teóricos são comparados com resultados experimentais obtidos a partir de ensaios em vigas mistas. O modelo é então utilizado como base para um cálculo iterativo aproximado, que também considera a flambagem local da mesa e da alma.

Os fatores que influenciam a resistência de vigas mistas contínuas ao momento negativo são: 
a) Taxa de armadura longitudinal existente na laje: A altura da zona comprimida da alma é controlada pela força resistente da armadura da laje. A flambagem local da alma e as tensões de compressão na mesa da viga de aço, por sua vez, limitam a taxa da armadura longitudinal da laje.

b) Instabilidade associada à distorção da seção: Uma considerável restrição lateral e ao giro é oferecida pela laje de concreto à mesa tracionada da viga de aço. A resistência a este tipo de instabilidade depende, portanto, da altura da alma capaz de transmitir a restrição até a mesa comprimida instável.

c) Flambagem local da alma e da mesa na zona comprimida: O momento resistente é reduzido quando a seção é suficientemente esbelta a fim de permitir que a flambagem local se desenvolva para níveis de carregamentos abaixo dos que provocariam flambagem por distorção.

\subsubsection{NBR 8800 (1986)}

A norma brasileira especifica que a resistência de vigas mistas sob momentos negativos seja admitida igual ao da viga de aço isolada, não permitindo que se considere a contribuição da armadura longitudinal na resistência. Obviamente, isso acarreta em um dimensionamento bastante conservador. A norma brasileira ainda cita que uma armadura especial para evitar a fissuração do concreto tracionado deve ser usada. Semelhante à norma americana e à canadense, a NBR 8800 não aborda sobre outros aspectos relevantes no dimensionamento de vigas mistas contínuas.

\subsubsection{AISC-LRFD (1994)}

Segundo a norma americana, o momento resistente de cálculo $\phi_{b} M_{n}$ em vigas contínuas deve ser igual ao da viga de aço isolada. Como alternativa, a norma permite que a resistência ao momento fletor negativo seja obtida a partir da plastificação total da seção, considerando-se a contribuição da armadura longitudinal contida na largura efetiva da laje, desde que a viga de aço pertença à classe das seções "compactas".

O momento nominal $M_{n}$ é calculado através das seguintes considerações: 
- A distribuição de tensões na seção é similar à apresentada na figura 3.12, sendo que a máxima tensão de tração ou compressão na viga de aço é igual a $f_{y}$;

- A força resultante de tração $T$ é dada pelo menor dos valores: $A_{s} f_{s y}$ e $Q_{n}=\sum q_{n}$

Neste caso, o coeficiente de resistência $\phi_{b}$ é igual a 0,85 .

A norma americana, diferente do EUROCODE 4 e da BS 5950, não aborda diversos pontos relevantes do dimensionamento de vigas mistas contínuas submetidas a momento negativo, tais como a instabilidade da mesa inferior (efeito distorcional), o efeito da cortante no momento resistente da seção mista, a redistribuição de momentos fletores devido ao efeito da fissuração do concreto, bem como as verificações no regime de utilização, tal como o deslocamento.

\subsubsection{CAN/CSA - S16.1 (1994)}

A norma canadense segue os mesmos critérios da norma americana, admitindo a consideração da armadura longitudinal da laje contida na sua largura efetiva, no cálculo da resistência ao momento fletor negativo.

\subsubsection{EUROCODE 4: PARTE 1.1 (1992)}

\section{Definição de Vigas Contínuas}

Segundo o EUROCODE 4, uma viga contínua é definida por uma viga de três ou mais apoios, na qual a seção de aço é contínua ou por meio de apoios internos ou pelas conexões viga/coluna do tipo resistência total e rigida. $^{[}$. As conexões entre

\footnotetext{
${ }^{1}$ As conexões de resistência total são aquelas em que a ruptura deve ser alcançada após atingido o estado limite último do elemento a ser ligado.

${ }^{2}$ As conexões rígidas caracterizam por apresentarem pequenas deformações de modo que não exercem influência significativa na distribuição de momentos na estrutura. (ver item 6.4.2 do EUROCODE 3 - Projeto de Estruturas de Aço: Parte 1-1).
} 
viga e cada apoio devem ser tais que se possa supor que cada apoio não transmita momentos fletores significativos para a viga.

\section{Obtenção de esforços em vigas mistas contínuas}

A perda de rigidez à flexão, causada pela fissuração do concreto em regiões de momento negativo e pelo escoamento do aço, influenciam a distribuição de momentos ao longo de vigas mistas contínuas.

Os momentos fletores podem ser obtidos utilizando-se dois métodos de análise: rigido-plástica e elástica.

No método baseado em cálculo elástico, a rigidez à flexão da viga pode ser assumida igual ao valor da rigidez referente à seção "não-fissurada" $\left(E I_{1}\right)$. Alternativamente, pode-se tomar o valor da rigidez à flexão $\left(E I_{2}\right)$ da seção totalmente "fissurada" (ou seja, despreza-se o concreto) numa região correspondente a $15 \%$ do vão de cada lado do apoio interno, e igual a $E I_{1}$ no restante da viga. A figura 3.11 ilustra estas duas alternativas. Os momentos solicitantes iniciais devem ser determinados por uma dessas opções citadas.

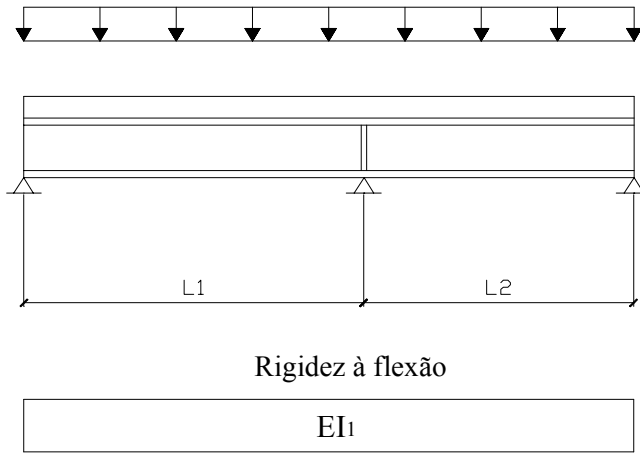

a) Seção "não-fissurada"
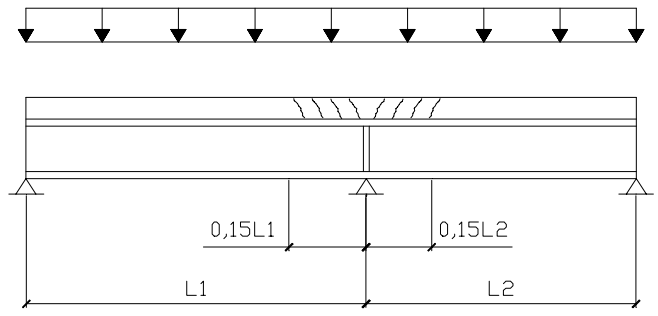

Rigidez à flexão

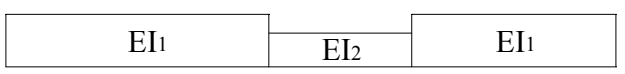

b) Seção "fissurada"

FIGURA 3.11: Rigidez à flexão ao longo de uma viga mista contínua utilizada na obtenção de momentos fletores considerando-se a análise elástica.

A redistribuição de momentos pode ser então aplicada em vigas mistas contínuas de mesma altura, reduzindo-se os máximos momentos negativos iniciais em porcentagens que não excedam as indicadas na tabela 3.4 . 
TABELA 3.4: Limites máximos da redistribuição de momentos fletores negativos em $\%$ e em relação ao momento fletor inicial a ser reduzido.

\begin{tabular}{|l|c|c|c|c|}
\hline $\begin{array}{l}\text { Classe da seção na região de momentos } \\
\text { negativos }\end{array}$ & 1 & 2 & 3 & 4 \\
\hline Análise elástica - Seção “não-fissurada” & 40 & 30 & 20 & 10 \\
\hline Análise elástica - Seção "fissurada” & 25 & 15 & 10 & 0 \\
\hline
\end{tabular}

Vale lembrar que, para manter-se equilíbrio estático, os momentos fletores positivos também devem ser alterados.

O método baseado na análise rígido-plástica permite maiores redistribuições dos momentos, especialmente em vigas contínuas de vãos desiguais. A redistribuição resulta da rotação inelástica de pequenos trechos da viga, onde se assume, teoricamente, a existência de rótulas plásticas. Essa rotação pode ser limitada pelo esmagamento do concreto ou pela flambagem da viga de aço, dependendo da geometria da seção, bem como da curva tensão x deformação dos materiais. A análise rigido-plástica pode ser utilizada para a determinação dos esforços, desde que sejam satisfeitos alguns requisitos apresentados nesta norma:

a) Na posição da rótula plástica:

- A seção transversal da viga de aço deve ser simétrica em relação ao plano da alma;

- A seção transversal da viga de aço deve pertencer à classe 1;

- A viga deve estar contida lateralmente.

b) Todos os elementos da seção pertençam à classe 1 ou 2;

c) Os vãos extremos não excedam 115\% do vãos adjacentes;

d) Vãos adjacentes não difiram mais que 50\% em relação ao menor vão da viga;

e) Quando a mesa comprimida da viga de aço esteja contida lateralmente.

\section{Cálculo do Momento Resistente:}


No cálculo do momento resistente, considera-se apenas a contribuição da viga de aço e da armadura longitudinal da laje contida na largura efetiva, desprezando-se o concreto submetido tanto à tração quanto à compressão. As máximas tensões permitidas nos materiais são:

- $f_{y} / \gamma_{a}$ na viga de aço, tanto à tração quanto à compressão;

- $f_{s y} / \gamma_{s}$ na armadura longitudinal da laje.

A largura efetiva da laje, no caso de vigas contínuas, pode ser determinada conforme o item 3.2.1.

A classe da seção transversal exerce grande influência na resistência à flexão da viga. A classe de uma alma, por exemplo, depende não somente da relação largura/espessura como também da distribuição de tensões ao longo da alma, segundo esta norma. Um aumento da taxa de armadura longitudinal da laje pode produzir um acréscimo na altura da alma que está sob compressão (pois a linha neutra é deslocada, alterando-se a distribuição de tensões), fazendo com que a alma passe de uma determinada classe para outra mais crítica. Isso provoca uma redução significativa no momento resistente.

A formulação apresentada a seguir baseia-se na análise plástica, válida somente para seções pertencentes às classes 1 ou 2 . 


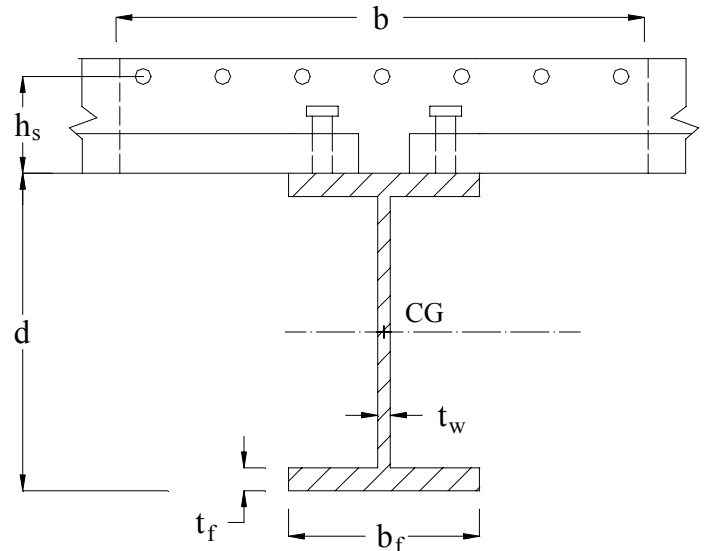

a)

Seção

Transversal

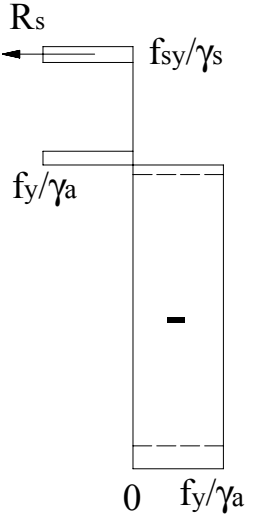

b)

$$
\text { L.N.P na }
$$
mesa superior

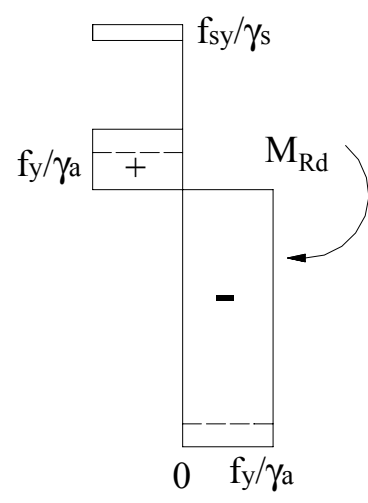

c)
L.N.P na alma

FIGURA 3.12: Distribuição de tensões em vigas mistas sob momento negativo

Na figura 3.12 a), $h_{s}$ é a distância entre a face inferior da laje e o eixo da armadura. A seguir, são apresentadas as forças resultantes nos vários elementos da viga e a nomenclatura utilizada nas expressões:

$R_{s}=\frac{A_{s} f_{s y}}{\gamma_{s}}$

$R_{f}=\frac{b_{f} t_{f} f_{y}}{\gamma_{a}}$

$R_{a}=\frac{A_{a} f_{y}}{\gamma_{a}}$

$R_{w}=\frac{h_{w} t_{w} f_{y}}{\gamma_{a}}$

$A_{s}$ é a área da seção transversal da armadura;

$f_{s y}$ é a resistência ao escoamento do aço da armadura.;

$\gamma_{s}$ é o coeficiente de resistência do aço da armadura.

Duas situações são possíveis:

a) Linha Neutra Plástica na viga de aço: $R_{s}<R_{a}$ 
a.1) L.N.P na alma:

Ocorre quando $R_{s}<R_{w}$

O momento resistente então é dado por:

$M_{R d}=\left(M_{p l, R d}\right)_{a}+R_{s}\left(\frac{d}{2}+h_{s}\right)-\frac{R_{s}^{2}}{R_{w}} \frac{h_{w}}{4}$

onde

$\left(M_{p l, R d}\right)_{a}$ é o momento resistente da viga de aço admitindo-se a plastificação total

a.2) L.N.P na mesa superior

Ocorre quando $R_{s} \geq R_{w}$

O momento resistente é dado por:

$M_{R d}=R_{a} \frac{d}{2}+R_{s} h_{s}-\frac{\left(R_{a}-R_{s}\right)^{2}}{R_{f}} \frac{t_{f}}{4}$

b) Linha Neutra Plástica fora da viga de aço: $R_{s} \geq R_{a}$

O momento resistente é calculado por:

$M_{R d}=R_{a}\left(\frac{d}{2}+h_{s}\right)$

Para que se tenha interação total, o número de conectores $N$ necessários entre a seção de momento positivo máximo e um apoio intermediário para resistir ao fluxo longitudinal deve atender à seguinte equação: 
$N=\frac{F_{p}+F_{n}}{q_{R d}}$

onde

$F_{p}$ é o menor valor entre $\frac{0,85 f_{c k} b t_{c}}{\gamma_{c}}$ e $\frac{A_{a} f_{y}}{\gamma_{a}}$

$F_{n}=\frac{A_{s} f_{s y}}{\gamma_{s}}+\frac{A_{p} f_{y p}}{\gamma_{a p}}$

$q_{R d}$ é a resistência individual de cálculo do conector;

$\gamma_{s}$ é o coeficiente de resistência do aço da armadura, igual a 1,15;

$A_{p}$ é a área efetiva da fôrma de aço (tracionada), caso seja empregada;

$f_{y p}$ é a resistência ao escoamento do aço da fôrma;

$\gamma_{a p}$ é o coeficiente de resistência do aço da fôrma, igual a 1,1 .

Notar que a força resultante $V_{h}$, no caso de interação total, é a soma das forças resultantes de tração da armadura e da fôrma de aço (caso esta última seja empregada) na região de momento negativo, com a resultante de compressão na laje de concreto na região de momento positivo (em geral, na metade do vão da viga).

A norma permite a interação parcial apenas em vigas mistas cujas seções pertençam às classes 1 ou 2 .

\section{Interação Momento - Cortante}

Normalmente, despreza-se a contribuição da laje de concreto na resistência à força cortante. Assume-se então que todo o esforço cortante é resistido pela alma da viga de aço.

A resistência de cálculo da viga de aço à força cortante $V_{p l, R d}$, admitindo-se plastificação total, é dada pela seguinte expressão, conforme o EUROCODE 3 (1992): Projeto de estruturas de aço: 
$V_{p l, R d}=\frac{A_{v}\left(\frac{f_{y}}{\sqrt{3}}\right)}{\gamma_{a}}$

onde

$A_{v}=1,04 d t_{w}$ para perfis tipo "I" laminado e igual a $h_{w} t_{w}$ para perfis tipo "I" soldados.

A verificação da flambagem local da alma por cisalhamento não é necessária se a relação largura/espessura não ultrapassar o valor:

$\frac{h_{w}}{t_{w}} \leq 69 \varepsilon \quad\left(\operatorname{com} \varepsilon=\sqrt{\frac{235}{f_{y}}}\right.$ e $f_{y}$ em MPa $)$

Quando a força cortante solicitante de cálculo $V_{S d}$ é maior que $50 \%$ da resistência de cálculo $V_{p l, R d}$, seu efeito deve ser levado em consideração no cálculo do momento resistente da viga mista, devendo-se obedecer o seguinte critério de interação:

$M_{S d} \leq M_{f, R d}+\left(M_{R d}-M_{f, R d}\left[1-\left(\frac{2 V_{S d}}{V_{p l, R d}}-1\right)^{2}\right]\right.$

onde

$M_{S d}$ é o momento solicitante de cálculo;

$M_{R d}$ é o momento resistente da viga mista;

$M_{f, R d}$ é o momento resistente da viga mista, considerando-se apenas a contribuição das mesas. 


\section{Instabilidade por distorção}

A mesa superior da viga de aço pode ser sempre considerada estável lateralmente, pois está vinculada à laje de concreto através dos conectores. Para a mesa inferior comprimida, entretanto, deve-se verificar a estabilidade à distorção.

No caso de vigas não escoradas, verifica-se a estabilidade com um momento fletor que é a soma dos momentos resultantes das ações na viga de aço isolada e das ações no elemento misto.

Nas regiões de momentos negativos pode ocorrer a instabilidade associada à distorção da seção, pois a laje de concreto não consegue evitar os deslocamentos laterais em toda a seção de aço. Neste caso, a forma da seção transversal não é mantida, diferente do caso da instabilidade lateral com torção, onde ocorrem apenas deslocamentos verticais, horizontais e giro. As figuras 3.13 a) e b) ilustram esses dois tipos de instabilidade.

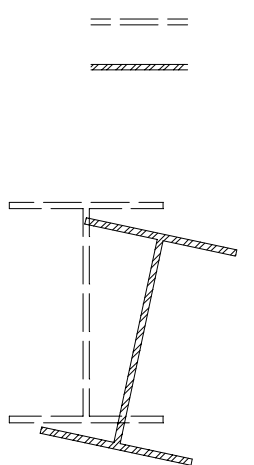

a)

nos apoios

na metade do vão

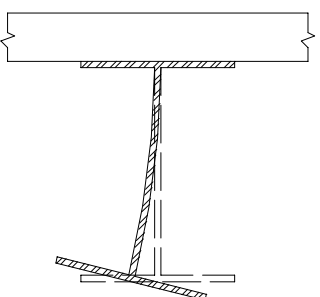

b)

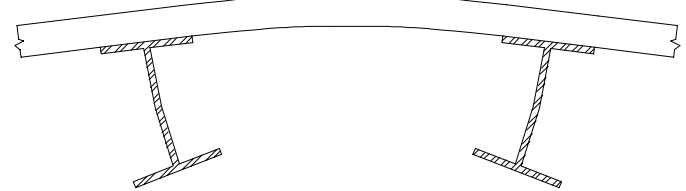

c)

FIGURA 3.13: a) Flambagem lateral com torção; b) Instabilidade associada à distorção da seção transversal da viga de aço; c) Pórtico em "U” invertido

Em edifícios é comum que várias vigas de aço estejam conectadas à mesma laje de concreto. A tendência das mesas inferiores comprimidas de deslocar-se lateralmente provoca uma deformada em forma de um pórtico tipo " $U$ " invertido entre duas vigas de aço adjacentes e a laje de concreto, conforme ilustra a figura 3.13 c). 
O valor do momento resistente à flambagem por distorção de uma viga não contida lateralmente é calculada da seguinte forma:

- Para seções pertencentes à classe 1 ou $2, \operatorname{com} \gamma_{R d}=1,0$ :

$M_{b, R d}=\chi_{L T} M_{p l, R d}\left(\frac{\gamma_{a}}{\gamma_{R d}}\right) \leq M_{p l, R d}$

- Para seções pertencentes à classe 3 , com $\gamma_{R d}=1,0$ :

$M_{b, R d}=\chi_{L T} M_{e l, R d}\left(\frac{\gamma_{a}}{\gamma_{R d}}\right) \leq M_{e l, R d}$

- Para seções pertencentes à classe 4:

$M_{b, R d}=\chi_{L T} M_{e l, R d} \leq M_{e l, R d}$

onde

$\chi_{L T}$ é o fator de redução da resistência associado à flambagem por distorção;

$\gamma_{a}$ é o coeficiente de resistência, igual a 1,1 ;

$M_{p l, R d}$ é o momento resistente admitindo plastificação total da seção;

$M_{e l, R d}$ é o momento resistente admitindo análise elástica da seção.

O valor de $\chi_{L T}$ é determinado por:

$$
\chi_{L T}=\frac{1}{\varphi_{L T}+\left(\varphi^{2}{ }_{L T}-\bar{\lambda}^{2}{ }_{L T}\right)^{\frac{1}{2}}} \quad \operatorname{com} \chi_{L T} \leq 1
$$

onde 
$\varphi_{L T}=0,5\left[1+\alpha_{L T}\left(\bar{\lambda}_{L T}-0,2\right)+\bar{\lambda}_{L T}^{2}\right]$

$\alpha_{L T}$ é igual a 0,21 para perfis laminados e igual a 0,49 para perfis soldados.

O valor de $\bar{\lambda}_{L T}$ é dado por:

$\bar{\lambda}_{L T}=\left(\frac{M_{p l}}{M_{c r}}\right)^{1 / 2}$ para seções das classes 1 ou 2;

$\bar{\lambda}_{L T}=\left(\frac{M_{e l}}{M_{c r}}\right)^{1 / 2}$ para seções das classes 3 ou 4.

onde

$M_{p l}$ é o valor do momento resistente da seção mista $M_{p l, R d}$ quando $\gamma_{a}, \gamma_{c}, \gamma_{s}$ são iguais a 1,0 ;

$M_{e l}$ é o valor do momento resistente $M_{e l, R d}$ quando $\gamma_{a}, \gamma_{c}, \gamma_{s}$ são iguais a 1,0;

$M_{c r}$ é o momento crítico elástico de flambagem por distorção.

$\mathrm{O}$ anexo $\mathrm{B}$ desta norma apresenta um método simplificado para o cálculo de $\bar{\lambda}_{L T} \mathrm{e}$ do momento crítico $M_{c r}$, com base no modelo de pórtico contínuo em "U”. No caso de vigas de aço com perfil tipo I duplamente simétricas, pertencentes à classe 1 ou 2:

$\bar{\lambda}_{L T}=5,0\left(1+\frac{t_{w} h_{a}}{4 b_{f} t_{f}}\right)\left[\left(\frac{f_{y}}{E C_{4}}\right)^{2}\left(\frac{h_{a}}{t_{w}}\right)^{3}\left(\frac{t_{f}}{b_{f}}\right)\right]^{0,25}$

onde

$h_{a}$ é a altura da viga de aço em relação a sua linha de esqueleto;

$C_{4}$ é um coeficiente que depende da distribuição dos momentos fletores ao longo do vão. $\mathrm{O}$ anexo $\mathrm{B}$ desta norma apresenta tabelas que fornecem os valores deste coeficiente para várias configurações de diagramas de momentos. 
Quando $\bar{\lambda}_{L T} \leq 0,4$ não é necessária a verificação da flambagem por distorção.

Esta norma permite que a verificação da estabilidade possa ser feita indiretamente, sem a necessidade de cálculo, desde que as seguintes condições sejam satisfeitas:

- Os vãos adjacentes ao menor vão da viga não difiram deste em mais de 20\%;

- O carregamento em cada vão seja uniformemente distribuído e a carga permanente de cálculo represente mais que $40 \%$ da carga total de cálculo;

- A conexão da mesa superior da viga de aço com a laje de concreto satisfaça todos os requisitos descritos nesta norma, tais como resistência, locação e espaçamento dos conectores de cisalhamento;

- A altura da laje de concreto deve ser tal que atenda a seguinte expressão:

$I_{c 2} \geq 0,35 \frac{E}{E_{c}} t_{w}{ }^{3} \frac{a}{d}$

onde

$I_{c 2}$ é o momento de inércia da seção transversal da laje, acima da viga de aço, por unidade de largura, na metade do vão da viga, desprezando-se o concreto tracionado e incluindo-se as áreas homogeneizadas da armadura longitudinal e da fôrma de aço, se esta última existir;

$E_{c}$ é o módulo de elasticidade do concreto;

$E$ é o módulo de elasticidade do aço;

$d$ é a altura total da viga de aço;

$t_{w}$ é a espessura da alma da viga de aço;

$a$ é a distância entre eixos de vigas adjacentes.

- A altura da viga de aço em relação a sua linha de esqueleto $h_{a}$ não deve superior aos seguintes valores:

$$
h_{a} \leq \frac{0,45 A_{a}}{t_{w}} \quad \text { e } \quad h_{a} \leq 820 t_{w}\left(\frac{b_{f}}{f_{y}^{2} t_{f}}\right)^{1 / 3}
$$

onde

$b_{f}$ é a largura da mesa da viga de aço; 
$t_{f}$ é a espessura da mesa da viga de aço;

$f_{y}$ é a resistência ao escoamento do aço da viga, em MPa.

\section{Deslocamentos:}

Os deslocamentos verticais de uma viga mista contínua são influenciados pela fissuração do concreto e pelo escoamento do aço da armadura nas regiões de momentos fletores negativos. Para levar em conta o efeito da fissuração, esta norma apresenta dois métodos de análise. O método abordado neste trabalho apresenta as seguintes condições de aplicabilidade:

- As vigas de aço devem pertencer às classes 1,2 ou 3;

- A tensão de tração na face superior da laje $\left(\sigma_{c t}\right)$, na região dos apoios, deve ser superior ao valor $0,15 f_{c k}$, sendo $\sigma_{c t}$ calculada por meio de uma distribuição linear de tensões utilizando-se as propriedades da seção "não fissurada".

Uma vez atendida a aplicabilidade desse método, calcula-se o momento de inércia $I_{1}$ da seção mista "não fissurada" e o momento de inércia $I_{2}$ da seção "fissurada" (ou seja, ignorando o concreto). Os momentos negativos nos apoios, obtidos pelo cálculo elástico, são multiplicados pelo fator de redução $f_{l}$, dado por:

$f_{1}=\left(\frac{I_{1}}{I_{2}}\right)^{-0,35} \operatorname{com} \quad 0,6 \leq f_{1} \leq 1,0$

A expressão (3.71) é aplicável quando a diferença entre vãos (distância entre apoios) adjacentes não for maior que $25 \%$ e os carregamentos nos tramos da viga forem iguais. Caso contrário, utiliza-se o limite inferior da redução, ou seja, $f_{1}=0,6$. Vale lembrar que, após a redução dos momentos negativos nos apoios, deve-se efetuar o correspondente incremento nos momentos fletores positivos dos vãos adjacentes.

No caso de vigas não escoradas, pode-se levar em conta a influência da plastificação local da viga de aço sobre o apoio da seguinte forma: multiplica-se o 
momento fletor no apoio, determinado conforme os dois parágrafos anteriores, por um fator de redução adicional $f_{2}$ igual a:

$f_{2}=0,5$, caso a tensão de escoamento seja atingida antes do endurecimento da laje de concreto;

$f_{2}=0,7$, caso a tensão de escoamento, resultante de cargas adicionais aplicadas, seja atingida depois do endurecimento da laje de concreto.

Os deslocamentos em vigas mistas contínuas são calculados em função dos momentos solicitantes já reduzidos.

\section{Fissuração do concreto:}

Esta norma apresenta diversos procedimentos e condições que permitem o controle da fissuração do concreto.

A fissuração deve ser limitada a um nível em que o funcionamento e a durabilidade da estrutura não sejam prejudicados, assim como a sua aparência. Devem ser estabelecidos limites apropriados da abertura de fissura no concreto, levando-se em conta a função e natureza da estrutura, assim como os custos associados à limitação da fissuração.

Em vigas mistas submetidas a momentos negativos, nas quais não se realize nenhum controle da abertura de fissuras do concreto, a taxa de armadura longitudinal disposta na largura efetiva da laje não deve ser inferior a:

- 0,4\% da área efetiva da laje para construção escorada;

- $\quad 0,2 \%$ da área efetiva da laje para construção não escorada.

A armadura deve ser disposta em um comprimento igual a 1/4 do vão em cada lado do apoio interno ou metade do comprimento do vão quando em balanço.

Quando for necessário o controle da abertura da fissura no concreto, a área mínima de armadura longitudinal $A_{s}$ necessária na região de momentos negativos em vigas mistas é dada por: 


$$
A_{s}=K K_{c} f_{c t} \frac{A_{c t}}{\sigma_{s t}}
$$

onde

$K$ é um coeficiente definido conforme o EUROCODE 2 (1992): "Projeto de estruturas de concreto". Segundo o EUROCODE 4, pode-se assumir o valor de 0,8 ; $K_{c}$ é um coeficiente que leva em conta a distribuição de tensões na laje de concreto antes da fissuração. Pode-se adotar, de forma conservadora, o valor 0,9. O cálculo exato é dado por:

$$
K_{c}=\frac{1}{1+\frac{t_{c}}{2 z_{o}}}
$$

$z_{o}$ é a distância entre o centro de gravidade da laje e o centro de gravidade da seção homogeneizada, desconsiderando-se a armadura;

$f_{c t}$ é a resistência do concreto à tração. Adota-se como valor mínimo 3,0 $\mathrm{MPa}$;

$A_{c t}$ é a área efetiva de concreto submetida à tração;

$\sigma_{s t}$ é a máxima tensão permitida na armadura, a qual depende do diâmetro máximo das barras, conforme a tabela 3.5:

TABELA 3.5: Máxima tensão nas barras da armadura em função do diâmetro em barras de alta aderência

\begin{tabular}{|c|c|c|c|c|c|c|c|c|}
\hline $\begin{array}{c}\text { Diâmetro máximo. } \\
\text { das barras (mm) }\end{array}$ & 6 & 8 & 10 & 12 & 16 & 20 & 25 & 32 \\
\hline Abertura da fissura & \multicolumn{7}{|c|}{ Máxima tensão na armadura $\sigma_{\text {st }}(\mathbf{M P a})$} \\
\hline $0,3 \mathrm{~mm}$ & 450 & 400 & 360 & 320 & 280 & 240 & 200 & 160 \\
\hline $0,5 \mathrm{~mm}$ & 500 & 500 & 500 & 450 & 380 & 340 & 300 & 260 \\
\hline
\end{tabular}

Quando a armadura necessária para resistir ao momento fletor, calculada no estado limite último, for maior que a armadura mínima de fissuração, a tensão de tração na armadura $\sigma_{s}$, obtida pelo cálculo elástico, deve ser determinada por: 
$\sigma_{s}=\sigma_{s e}+\frac{0,4 f_{c t m} A_{c t}}{\alpha A_{s}}$

onde

$\sigma_{s e}$ é a tensão na armadura mais próxima da face superior da laje, calculada desprezando-se o concreto tracionado;

$f_{c t m}$ é a resistência média do concreto à tração;

$A_{s}$ é a área total de armadura longitudinal contida na largura efetiva da laje;

$\alpha=\frac{A I}{A_{a} I_{a}}$

$A$ e $I$ são a área e o momento de inércia, respectivamente, da seção mista, desprezando-se o concreto tracionado e a área de fôrmas de aço, caso existam; $A_{a}$ e $I_{a}$ são a área e o momento de inércia, respectivamente, da seção da viga de aço.

A tabela 3.6 apresenta o espaçamento máximo entre as barras da armadura em função da tensão atuante nessas, calculada conforme a expressão (3.73), e em função da abertura de fissura no concreto.

TABELA 3.6: Espaçamento máximo, em mm, entre barras de alta aderência

\begin{tabular}{|c|c|c|c|c|c|c|c|c|}
\hline \multicolumn{2}{|c|}{ Tensão na armadura $\sigma_{s}(M P a)$} & $\leq 160$ & 200 & 240 & 280 & 320 & 360 & 400 \\
\hline \multirow{3}{*}{$\begin{array}{l}\text { Espaçamento } \\
\text { máx. entre } \\
\text { barras (mm) }\end{array}$} & Abertura da fissura & & & & & & & \\
\hline & $0,3 \mathrm{~mm}$ & 250 & 200 & 160 & 110 & \multicolumn{3}{|c|}{ Aplicar tabela 3.5} \\
\hline & $0,5 \mathrm{~mm}$ & 250 & 250 & 250 & 250 & 200 & 140 & 80 \\
\hline
\end{tabular}

Quando é aplicável a tabela 3.6, o controle da fissuração é dado pelo espaçamento máximo entre barras; caso contrário, o controle da fissuração é feito limitando-se o diâmetro das barras, conforme a tabela 3.5.

Vale salientar que o termo alta aderência está associado à capacidade de mobilização de tensões de compressão no concreto devido à conformação superficial das barras, as quais apresentam saliências. 


\subsubsection{BS 5950 (1990)}

A norma britânica apresenta as mesmas hipóteses de cálculo do EUROCODE 4, utilizadas na determinação do momento resistente da viga mista, conservando-se as tensões máximas nos materiais conforme o item 3.3.1.5.

A norma apresenta três métodos para a obtenção dos momentos fletores ao longo da viga. Um dos métodos consiste num procedimento similar ao EUROCODE 4, determinando-se inicialmente os momentos solicitantes baseados no cálculo elástico e nas propriedades da seção mista "não-fissurada", com posterior redistribuição desses momentos em percentagens máximas indicadas na tabela 3.7.

TABELA 3.7: Limites máximos da redistribuição de momentos fletores negativos em $\%$ e em relação ao momento fletor inicial a ser reduzido.

\begin{tabular}{|l|c|c|c|c|}
\hline $\begin{array}{l}\text { Classe da mesa comprimida no apoio } \\
\text { interno (momento negativo) }\end{array}$ & 1 & 2 & 3 & 4 \\
\hline Análise elástica - Seção “não-fissurada” & 40 & 30 & 20 & 10 \\
\hline
\end{tabular}

A segunda forma de se obter os esforços consiste num método simplificado, onde os momentos solicitantes são obtidos multiplicando-se um coeficiente fornecido na tabela 3 desta norma, em função da classe da mesa comprimida e da posição do vão analisado - pelo momento $p L^{2} / 8$, onde $p$ é o carregamento uniformemente distribuído de cálculo no vão $L$. Para a aplicação deste método, devem ser satisfeitas algumas condições prescritas pela norma.

A terceira alternativa para a determinação dos esforços baseia-se na análise rígido plástica da seção, devendo ser aplicada somente a seções pertencentes à classe 1. As condições para que este método seja aplicado consistem basicamente nas mesmas condições apresentadas pelo EUROCODE 4.

$\mathrm{O}$ momento resistente para seções pertencentes às classes 1 e 2 pode ser determinado conforme as equações (3.59), (3.60) e (3.61), devendo-se alterar apenas as forças resistentes nos vários elementos da viga por: 
$R_{s}=0,87 A_{s} f_{s y}$

$R_{f}=b_{f} t_{f} f_{y}$

$R_{a}=A_{a} f_{y}$

$R_{w}=h_{w} t_{w} f_{y}$

$R_{o}=38 \varepsilon t_{w}^{2} f_{y}$

$R_{n}=R_{a}-R_{w}+R_{o}$

$\varepsilon=\sqrt{\frac{275}{f_{y}}}, \operatorname{com} f_{y} \mathrm{em} \mathrm{MPa}$

O momento resistente de cálculo para perfis duplamente simétricos cujas seções pertencem às classes 3 ou 4 é determinado considerando-se três situações:

a) L.N.P na alma: $\frac{h_{w}}{t_{w}}>38 \varepsilon$ e $\frac{h_{w}}{t_{w}}>\frac{76 \varepsilon}{1+\frac{R_{s}}{R_{w}}}$

$M_{R d}=\left(M_{R d}\right)_{a}+R_{s}\left(\frac{d}{2}+h_{s}\right)-\frac{R_{s}{ }^{2}+\left(R_{w}+R_{s}\right)\left(R_{w}+R_{s}-2 R_{o}\right)}{R_{w}} \frac{h_{w}}{4}$

b) L.N.P na mesa superior da viga de aço: $\frac{h_{w}}{t_{w}}>38 \varepsilon$

Ocorre quando $R_{S}<R_{n}$

O momento resistente é dado por:

$M_{R d}=R_{n} \frac{d}{2}+R_{s} h_{s}-\frac{\left(R_{n}-R_{s}\right)^{2}}{R_{f}} \frac{t_{f}}{4}$

c) L.N.P na laje: $\frac{h_{w}}{t_{w}}>38 \varepsilon$

Ocorre quando $R_{s} \geq R_{n}$ 
O momento resistente é dado por:

$$
M_{R d}=R_{n}\left(\frac{d}{2}+h_{s}\right)
$$

O número total de conectores $N$ entre uma seção de momento máximo positivo e cada apoio adjacente não deve ser menor que:

$$
N \geq \frac{F_{p}}{\left(q_{R d}\right)_{p}}+\frac{F_{n}}{\left(q_{R d}\right)_{n}}
$$

onde

$F_{p}$ é o menor dos valores $A_{a} f_{y}$ e $0,45 f_{c k} b t_{c}$;

$F_{n}=0,87 A_{s} f_{s y}$

$\left(q_{R d}\right)_{p}$ é a resistência de cálculo do conector sob momento positivo;

$\left(q_{R d}\right)_{n}$ é a resistência de cálculo do conector sob momento negativo.

A estabilidade da mesa inferior deve ser verificada em cada vão mediante a seguinte situação: iguala-se os momentos nos dois apoios do vão considerado ao momento resistente e aplica-se os carregamentos permanentes de cálculo nesse vão. Os momentos nos apoios, resultantes dessa superposição, entretanto, não devem ser maiores que os obtidos a partir da análise elástica (utilizando-se as propriedades da seção "não-fissurada") sem a redistribuição de momentos.

A influência da força cortante no momento resistente da viga é avaliada da mesma maneira da apresentada no EUROCODE 4.

Os deslocamentos na metade do vão em vigas contínuas são determinados conforme a expressão (3.78), para carregamento uniforme ou cargas concentradas simétricas:

$\delta=\delta_{0}\left[1-0,6\left(\frac{M_{1}+M_{2}}{M_{0}}\right)\right]$ 
onde

$M_{0}, \delta_{0}$ são o momento fletor e deslocamento vertical, respectivamente, na metade do vão de uma viga simplesmente apoiada de mesmo vão;

$M_{1}, M_{2}$ são os momentos de extremidade no tramo analisado.

Os momentos $M_{1}$ e $M_{2}$ nos apoios são obtidos a partir da análise elástica da seção "não-fissurada". Em edifícios usuais, esses momentos são reduzidos para levar em conta o efeito do tipo de carregamento do edifício e da fissuração do concreto. Essa redução pode ser adotada conforme as percentagens apresentadas na tabela 3.4, utilizada na redistribuição de momentos no estado limite último, porém não menor que 30\%. Nos demais edifícios, onde predominam cargas variáveis excessivas (armazenamento), essa redução pode ser de 50\%.

Grandes redistribuições de momentos podem afetar adversamente o comportamento da viga no regime de utilização. Em vista disso, quando o momento resistente é determinado com base na plastificação da seção ou quando a redistribuição de momentos excede $40 \%$ considerando as propriedades da seção "não-fissurada" ou 20\% considerando as propriedades da seção "fissurada", deve-se levar conta o acréscimo nos deslocamentos permanentes como conseqüência da excessiva redistribuição de momentos. Este efeito é identificado na norma britânica como "shakedown", sendo abordado no item 6.1.3.3 desta norma.

Com relação à fissuração, quando for necessário controlar a abertura de fissuras, deve-se consultar a norma britânica BS 8110. Quando as condições do meio não propiciem a corrosão, não é necessário, normalmente, o controle da abertura de fissuras, mesmo quando as vigas mistas sejam calculadas como simplesmente apoiadas, desde que a laje de concreto seja armada convenientemente, segundo as especificações da BS 5950: Parte 4 e da BS 8110. 


\subsubsection{CONSIDERAÇÕES SOBRE O DIMENSIONAMENTO DE VIGAS MISTAS CONTÍNUAS}

A determinação dos esforços para verificação de vigas mistas contínuas no estado limite último pode ser ou feita pelo cálculo elástico, onde os momentos são redistribuídos em função de uma redução dos momentos nos apoios, ou pelo método baseado na análise rígido-plástica. Este último pode conduzir a vigas mais leves ou de menor altura, pois acarreta em maiores redistribuições de momentos. No entanto, a utilização de tal método está limitada a condições prescritas pelas normas para a sua aplicação, conforme já explicitadas.

Os deslocamentos verticais no estado limite de utilização são menos críticos em vigas contínuas que em vigas simplesmente apoiadas. No entanto, quando o dimensionamento da viga no estado limite último é feito pelo método baseado na análise rígido plástica, os deslocamentos verticais devem sempre ser verificados, segundo JOHNSON (1994). O efeito do escorregamento na interface da viga de aço com a laje é desprezado, uma vez que a interação parcial não é utilizada em regiões de momento negativo.

Com o objetivo de considerar a variação da rigidez à flexão entre seções de momento positivo e negativo na instabilidade de vigas mistas contínuas, WILLIAMS et al. (1993) apresentaram curvas de flambagem associadas ao efeito distorcional em vigas mistas de vão único e de extremidades engastadas, rotuladas ou livres, admitindo-se distribuição linear de tensões ao longo da seção. Esta análise permitiu a consideração da variação da rigidez à flexão, devido à fissuração do concreto tracionado. A comparação entre as curvas de flambagem mostrou que as condições de vinculação nas extremidades (restrições oferecidas às mesas no plano da viga) exercem grande influência na flambagem por efeito distorcional de vigas mistas.

$\mathrm{Na}$ verificação da resistência da seção mista, a largura efetiva da viga nas regiões de momentos negativos é geralmente menor que a das regiões próximas a metade do vão (momentos positivos). Nas verificações associadas ao estados limites de utilização, por simplicidade, pode-se assumir largura efetiva constante em todo o vão, tomando-se o valor correspondente à metade do vão. 
JOHNSON (1994) apresenta algumas observações e recomendações relacionadas ao dimensionamento de vigas mistas contínuas. Salienta que a continuidade é mais vantajosa em vigas de três ou mais vãos, com vãos externos menores em relação aos internos, que em vigas de dois vãos apenas.

A classe da seção na região dos apoios é outra decisão importante no dimensionamento. Para fazer uma análise qualitativa, duas situações são comparadas:

a) Emprego de armaduras na laje de combate à fissuração apenas, ignorando a parcela de resistência no estado limite último. A seção mista provavelmente pertenceria à classe 1 , e dessa forma, o método baseado na análise rígido-plástica poderia ser utilizado, devendo-se garantir que a viga esteja contida lateralmente ou que $\lambda_{L T}<0,4$.

b) Emprego de armadura longitudinal que contribui na resistência da seção mista, com área da seção transversal de, no mínimo, $1 \%$ da área efetiva da laje. A seção provavelmente pertenceria à classe 2 ou 3. Os momentos negativos solicitantes seriam maiores que a situação a), pois a redistribuição de momentos é menor para classes mais "críticas". Isto acarretaria em vigas de aço mais robustas, não sendo totalmente aproveitada a resistência ao momento fletor positivo no centro do vão. Entretanto, este fato possibilita que um grau de conexão menor seja empregado. Sendo maiores os momentos negativos solicitantes, a instabilidade associada ao efeito distorcional seria mais adversa. Os deslocamentos verticais seriam menores que a situação a), porém, pelo fato de a armadura longitudinal provavelmente possuir barras com diâmetro maior, o controle da fissuração do concreto tornar-se-ia mais difícil. 


\subsection{INTRODUÇÃO}

O sistema de lajes mistas consiste na utilização de uma fôrma de aço nervurada como fôrma permanente de suporte para o concreto antes da cura e das cargas de utilização. Após a cura do concreto, os dois materiais, a fôrma de aço e o concreto, combinam-se estruturalmente, formando o sistema misto. A fôrma de aço substitui então a armadura positiva da laje.

A utilização do sistema de lajes mistas em edifícios no Brasil é recente e tem aumentado consideravelmente. Na Europa e nos Estados Unidos, a utilização desse sistema em edifícios e pontes é mais comum.

Segundo CRISINEL \& O'LEARY (1996), os primeiros sistemas de lajes mistas surgiram no final da década de 30, apresentando-se como substitutos ao sistema tradicional de lajes de concreto armado e sendo utilizados inicialmente em edifícios altos. Na Europa, o sistema de lajes mistas apareceu no final da 50, utilizando-se fôrmas de aço corrugadas, apoiadas em vigas de aço. A interação entre a fôrma de aço e o concreto, nessa ocasião, realizava-se unicamente por atrito. $\mathrm{Na}$ metade da década de 60, as fôrmas de aço perfiladas foram introduzidas dos Estados Unidos para a Europa.

Atualmente, vários sistemas têm sido utilizados no processo de construção de fôrmas para suportar o concreto durante a fase de execução das lajes. Entre esses sistemas, o steel deck constitui-se como um dos mais apropriados em termos de construção de lajes (ver figura 4.1). Este sistema tem se transformado em tecnologia padrão nos países industrializados. É um processo largamente empregado na Europa, 
nos Estados Unidos e Japão, onde o seu uso destaca-se na construção de shopping centers, hotéis, hospitais, edifícios residenciais, edifícios comerciais ou garagens.

São diversas as funções das fôrmas de aço empregadas em lajes mistas. Além de suportarem os carregamentos durante a construção e funcionarem como plataforma de trabalho, contraventam lateralmente a estrutura, desempenhando o papel de diafragma horizontal. Além disso, pelo fato de distribuírem as deformações por retração, evitam a fissuração excessiva do concreto.

Os sistemas de lajes mistas apresentam algumas vantagens. Entre elas, podese citar a possibilidade de dispensa do escoramento da laje e a facilidade oferecida à passagem de dutos de eletricidade, comunicações, ar condicionado e de outros sistemas. Quando apresentam mossas, propiciam uma maior resistência mecânica ao cisalhamento, entre a fôrma de aço e o concreto. Além disso, por ser mais leve que outros sistemas, pode oferecer alguma economia no custo da fundação.

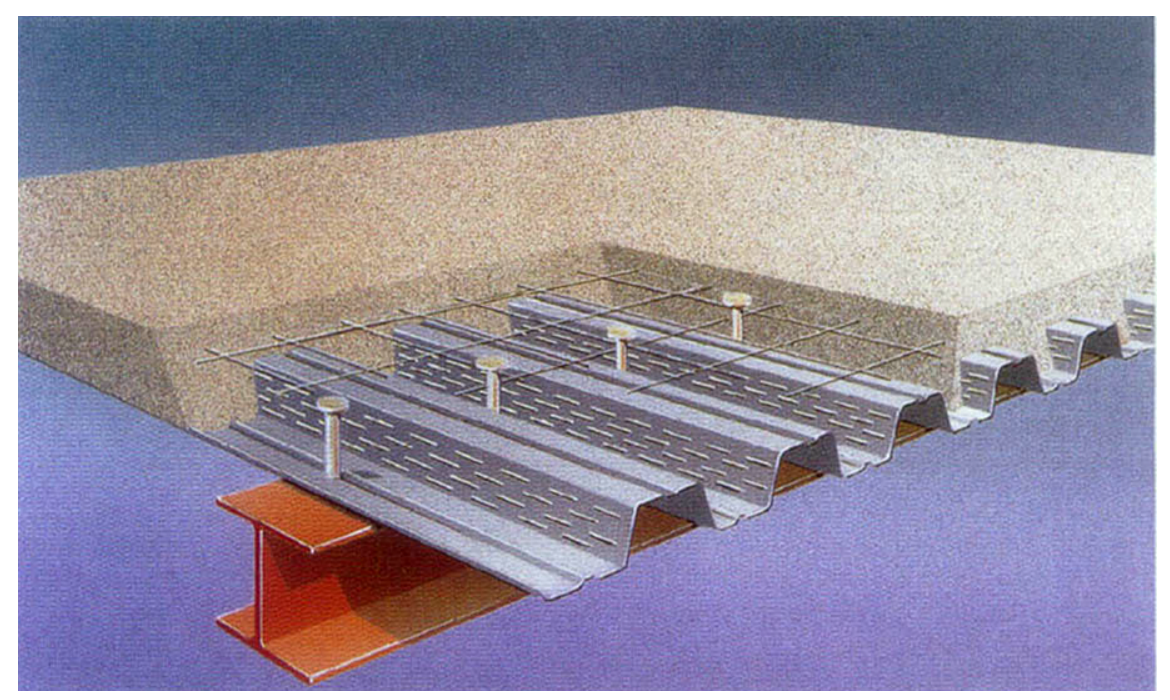

FIGURA 4.1: Exemplo do sistema de lajes mistas- Steel Deck CE-75 - Extraído do catálogo CODEME

\subsection{ASPECTOS CONSTRUTIVOS}

O comportamento misto é alcançado após o endurecimento do concreto da laje, quando a fôrma de aço transmite as tensões cisalhantes horizontais na interface 
com o concreto. A figura 4.2 ilustra os procedimentos de algumas ligações típicas em lajes mistas, os quais conferem o comportamento misto à estrutura:

a) Ligações mecânicas fornecidas por saliências e reentrâncias (mossas) existentes na fôrma;

b) Ligações por atrito, em perfis de chapa modelados numa fôrma reentrante;

c) Ancoragem de extremidade fornecida por conectores tipo stud ou por outro tipo de ligação local, em combinação com a) e b);

d) Ancoragem de extremidade obtida pela deformação das nervuras na extremidade da fôrma, em combinação com b).
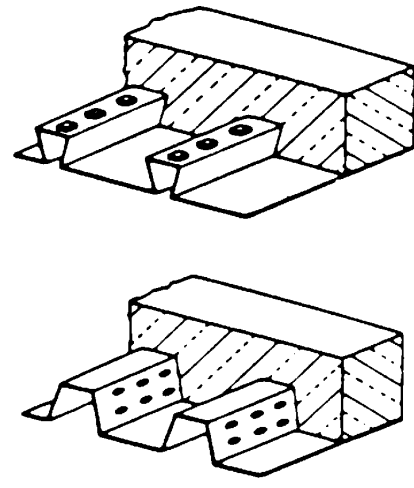

a)
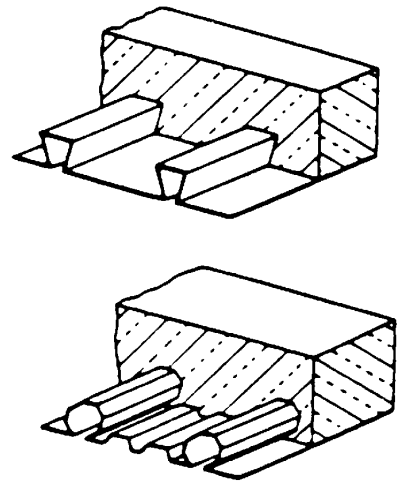

b)

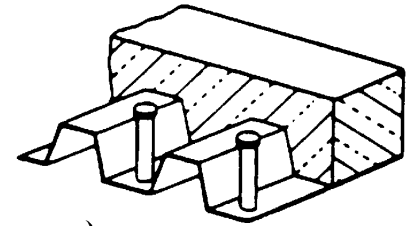

c)

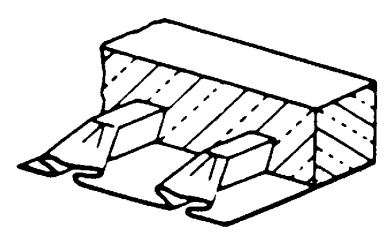

d)

FIGURA 4.2: Fôrmas típicas de ligação em lajes mistas

Altura da laje e a armadura

O EUROCODE 4 (1992) faz as seguintes recomendações com relação às dimensões da fôrma de aço e da laje de concreto:

a) A altura total da laje mista $h$ deve ser maior ou igual que $80 \mathrm{~mm}$. A altura de concreto $h_{c}$, medida a partir da superfície plana superior até as nervuras da fôrma deve ser maior ou igual a $40 \mathrm{~mm}$.

b) Se a laje atua como parte de uma viga mista ou é utilizada como diafragma , a altura total deve ser maior ou igual a $90 \mathrm{~mm}$ e $h_{c}$ maior ou igual a $50 \mathrm{~mm}$. 
c) Quando for necessária a colocação de armadura dentro da altura $h_{c}$ do concreto, o espaçamento máximo das barras deve atender o item 5.4.3.2.1 do EUROCODE 2 (1991): "Projeto de Estruturas de Concreto", com base na altura total $h$ da laje mista, exceto quando se deseja um espaçamento inferior, a fim de controlar a fissuração.

A figura 4.3 ilustra as recomendações dadas em a),b) e c):

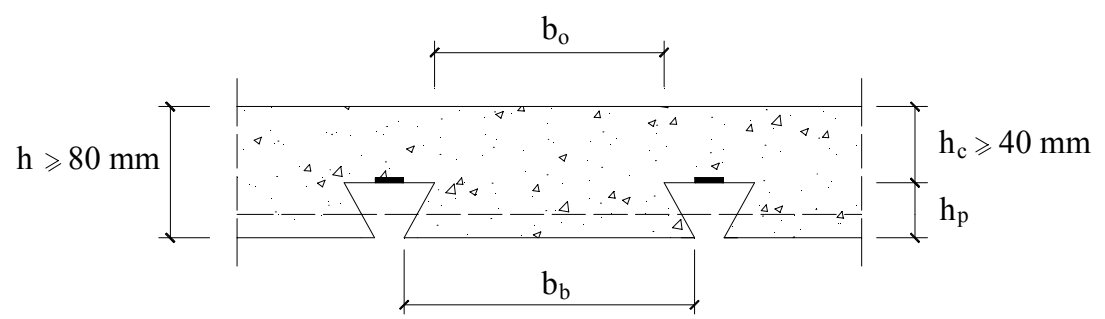

Perfil formando um ângulo agudo com a chapa base

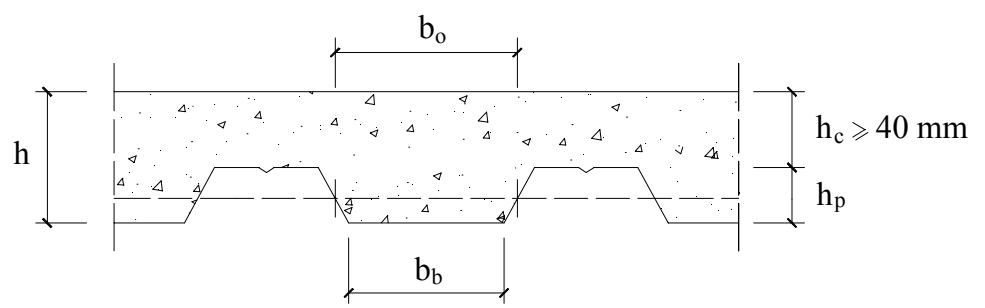

Perfil formando um ângulo obtuso com a chapa base

FIGURA 4.3: Dimensões típicas da fôrma de aço e da laje de concretoEUROCODE 4 (1992)

\section{Comprimento mínimo de apoios}

O detalhamento adequado dos apoios é essencial para o uso seguro da fôrma de aço como plataforma. Segundo o EUROCODE 4, os apoios devem obedecer os seguintes requisitos.

- Lajes mistas que se apoiam em concreto ou em aço devem ter um comprimento mínimo de apoio igual a $75 \mathrm{~mm}$, com um apoio extremo para a fôrma de aço de, no mínimo, $50 \mathrm{~mm}$, conforme as figuras 4.4 a) e c). 
- Para lajes mistas que se apoiam em outros materiais, esses valores aumentam para $100 \mathrm{~mm}$ e $70 \mathrm{~mm}$, respectivamente, conforme as figuras $4.4 \mathrm{~b}$ ) e d).

- Em fôrmas superpostas e em fôrmas contínuas, o comprimento mínimo de apoio deve ser: $75 \mathrm{~mm}$ para lajes mistas que se apoiem em concreto ou em aço; 100 mm para apoios constituídos de outros materiais, conforme as figuras 4.4 e) e f).
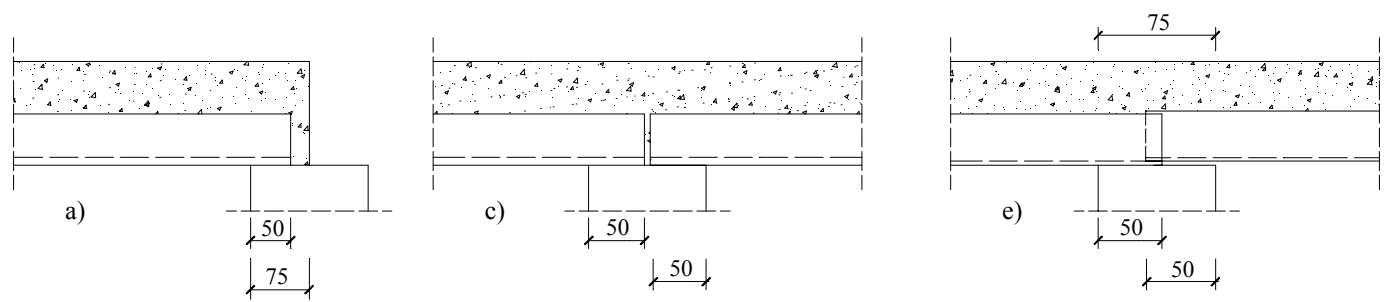

Apoio sobre concreto ou aço
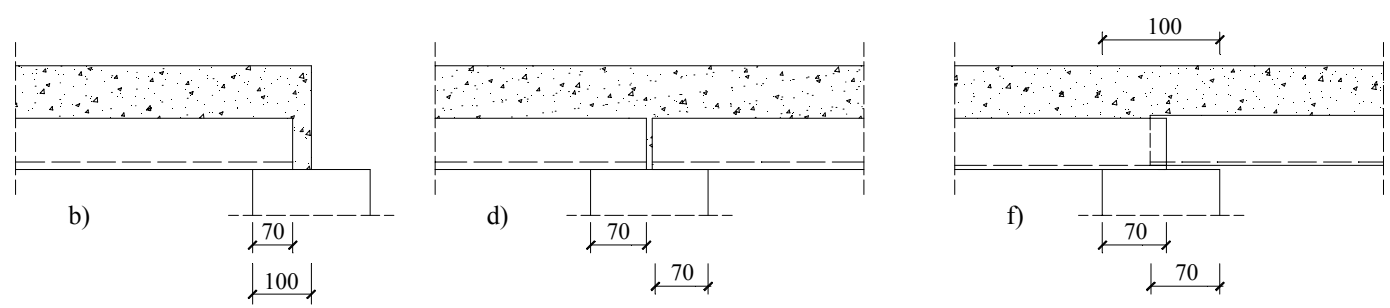

Apoio sobre outros materiais

FIGURA 4.4: Comprimentos mínimos de apoio - EUROCODE 4 (1992)

\section{Montagem e Fixação}

Após a conclusão da montagem das vigas de aço da estrutura, pode-se prosseguir com a instalação dos painéis das fôrmas de aço e de seus acessórios. Antes, porém, alguns procedimentos devem ser tomados a fim de garantir a eficiência da fixação da fôrma. Entre estas verificações, recomendadas também pelo EUROCODE 4, pode-se citar:

- nivelamento correto da mesa superior da viga de aço, de modo que se tenha um perfeito contato entre a fôrma e a viga;

- Remoção de ferrugem e de outras sujeiras;

- Remoção da pintura nas proximidades da região de soldagem 
Após as conferências necessárias, os painéis são posicionados sobre o vigamento. É usual a necessidade de recortes e ajustes nos cantos e no contorno de pilares, a fim de adaptar a laje à geometria da edificação.

Uma vez realizados todos os ajustes e o alinhamento, os painéis devem ser fixados à estrutura. Recomenda-se que, inicialmente, seja feita uma fixação preliminar, utilizando rebites. Dessa maneira, garante-se que o painel são saia da posição correta até que a fixação definitiva seja concluída.

A fixação definitiva dos painéis é executada por meio de pontos de solda bujão ou solda tampão, fazendo-se primeiramente uma abertura na chapa da fôrma. Recomenda-se que se faça um ponto de solda bujão em todas as ondas baixas da fôrma de aço sobre as vigas suporte, as quais são perpendiculares ao sentido das nervuras. Para as vigas paralelas às nervuras, recomenda-se que os pontos de solda bujão sejam executados ao longo do comprimento dos painéis (ver figura 4.5)

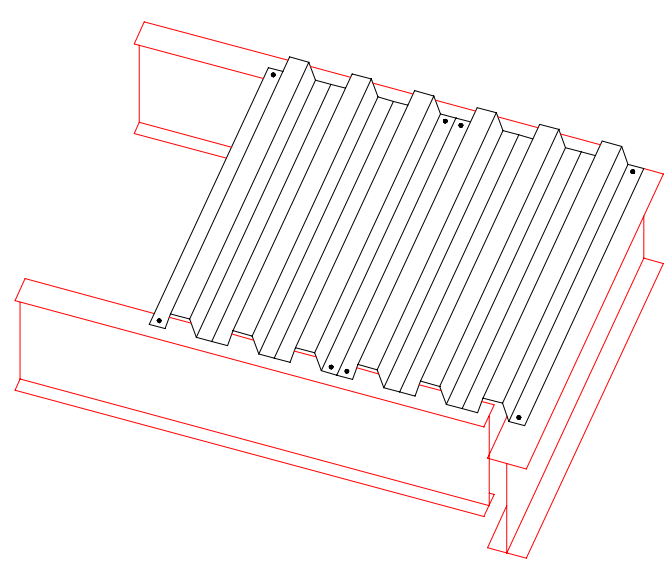

Fixação preliminar com rebites

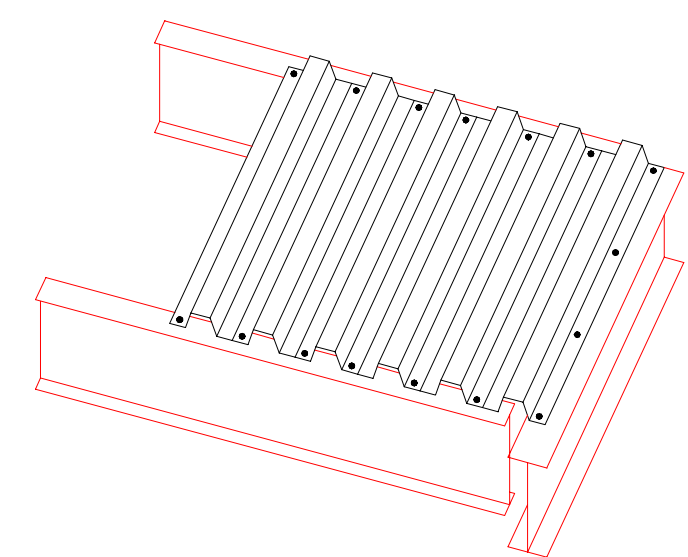

Fixação definitiva com solda bujão

FIGURA 4.5: Esquema típico de fixação preliminar e definitiva dos painéis nas vigas de aço

Após o término da montagem da fôrma de aço, devem ser fixados os conectores de cisalhamento. Estes conectores deverão ser soldados na viga, através da fôrma de aço, mediante uma solda de eletrofusão. O conector mais utilizado no sistema de lajes mistas é o tipo pino com cabeça (stud bolt). 
Alguns cuidados devem ser tomados devem ser tomados na execução da fixação dos conectores. O EUROCODE 4 (1992) recomenda que se verifiquem alguns procedimentos :

- Evitar a presença de umidade na soldagem do conector. Por esse motivo, é mais conveniente que a aplicação dos conectores seja feita logo após a montagem da fôrma de aço, evitando a possibilidade de acúmulo de água entre os painéis e a face superior das vigas de aço;

- Os conectores não devem ser soldados através de mais de um painel de fôrma.

- A espessura total da fôrma de aço não deve exceder 1,25 mm para fôrmas galvanizadas e 1,50 mm no caso de fôrmas não galvanizadas.

Após a conclusão da montagem, da fixação da fôrma e da instalação dos conectores de cisalhamento, pode-se dar início a instalação das armaduras adicionais das lajes. 


\subsection{COMPORTAMENTO ESTRUTURAL}

\subsubsection{GENERALIDADES}

Dentre os principais fatores que influenciam a resistência das lajes mistas, pode-se destacar:

- Resistência do concreto;

- Características geométricas da fôrma de aço;

- Ancoragem existente entre a fôrma de aço e o concreto.

Pesquisas têm sido desenvolvidas buscando avaliar a interferência destes parâmetros, através de análises experimentais e numéricas, de modo que possam ser consideradas no dimensionamento.

EASTERLING \& YOUNG (1992) apresentaram um método analítico aproximado para a determinação da resistência à flexão de lajes mistas, com base no cálculo convencional de concreto armado. O método apresentado leva em consideração a influência dos detalhes construtivos típicos na resistência da laje mista, o que conduz a uma precisão suficiente para efeito de cálculo. Compararam as expressões analíticas propostas com os resultados de ensaios experimentais em seis protótipos de lajes mistas simplesmente apoiadas, onde também foi avaliada a influência de lajes adjacentes. Concluíram que o procedimento de cálculo relativo ao dimensionamento de lajes mistas recomendado pela American Society of Civil Engineers (ASCE): Specifications for The Design and Construction of Composite Slabs, de 1984, não avalia com precisão satisfatória os efeitos da existência de lajes adjacentes nem dos detalhes construtivos típicos, como por exemplo as condições de ancoragem de extremidade através de conectores tipo pino com cabeça ou de perfis formados a frio. Por outro lado, concluíram que os deslocamentos em regime de utilização podem ser previstos com precisão satisfatória seguindo-se as recomendações da ASCE (Specifications 1984), a qual utiliza o conceito de 
homogeneização da seção, transformando a seção mista em uma seção de equivalente de concreto.

DANIELS \& CRISINEL (1993) propuseram um novo procedimento de cálculo como alternativa aos ensaios em escala real de lajes mistas com fôrma de aço incorporada apresentando nervuras. Tal procedimento consistiu na combinação de resultados experimentais, obtidos do método semi-empírico " $m e k$ ", com uma análise numérica, a fim de determinar a resistência de lajes mistas e de seu comportamento, aplicável tanto em lajes simplesmente apoiadas como em contínuas. Os ensaios utilizados foram o pull out test - escolhido para investigar o comportamento e a resistência da ligação na interface entre a fôrma de aço e o concreto - e o push off test - adotado para investigar o comportamento e a resistência da ancoragem de extremidade entre o perfil de aço, a fôrma de aço e a laje de concreto nos apoios. Os procedimentos realizados em ambos os ensaios foram descritos. Adotaram hipóteses e simplificações, com relação às propriedades dos materiais, que conduziram a previsões razoáveis da resistência e do comportamento de lajes mistas. As vantagens do procedimento de cálculo citadas foram a versatilidade e o custo reduzido, além da possibilidade de estimativa dos deslocamentos para carregamentos em regime de serviço, e da análise de parâmetros adicionais, tais como a ancoragem de extremidade (nos apoios), a contribuição da armadura positiva adicional na laje, a contribuição de armadura existente nas regiões de momento negativo e da aplicação em lajes contínuas. As figuras 4.6 e 4.7 ilustram os ensaios pull out test e push off test. 


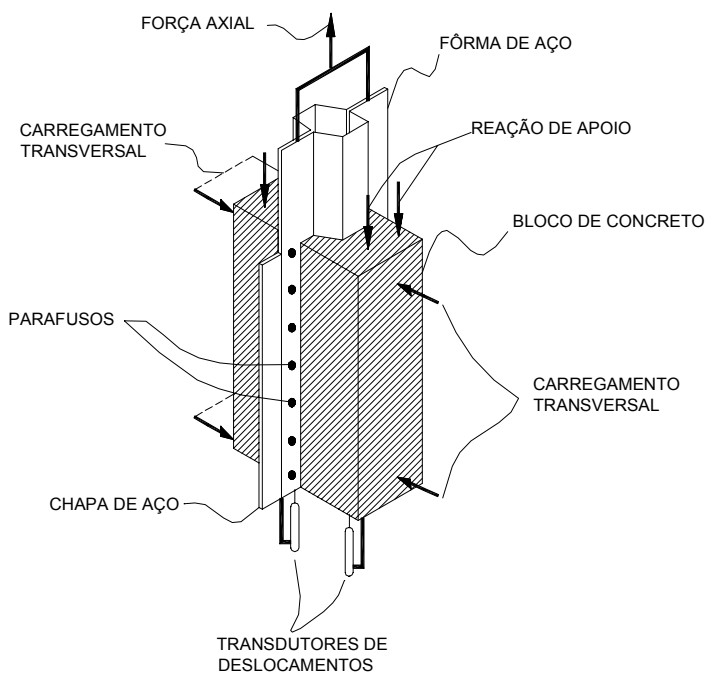

FIGURA 4.6: Esquema típico do ensaio pull-out test

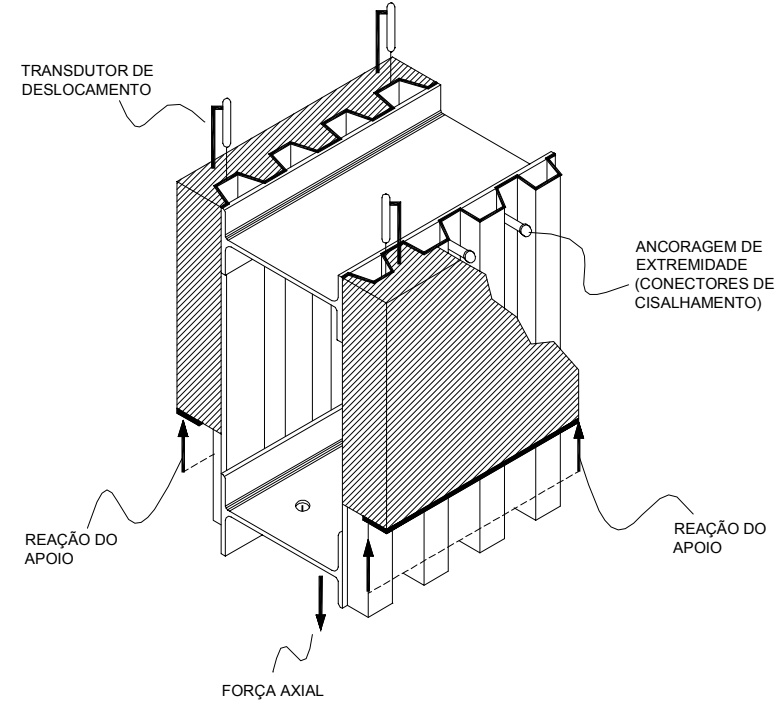

FIGURA 4.7: Esquema típico do ensaio push-off test

PATRICK \& BRIDGE (1994) apresentaram um novo método para a previsão do momento fletor resistente em lajes mistas simplesmente apoiadas sob qualquer condição de carregamento. O modelo incorpora o desempenho da ligação aço/concreto a partir do ensaio denominado slip block test, o qual é abordado por PATRICK (1990) e PATRICK (1991). Os ensaios realizados em escala reduzida mostraram que o desempenho da ligação ao cisalhamento aço/concreto é influenciado por fatores como: geometria da fôrma de aço, a espessura do metal base 
e pela resistência à compressão do concreto. Propuseram um novo método para o cálculo do momento fletor resistente em lajes mistas no caso de interação parcial, levando em conta fatores que influenciam a resistência de lajes mistas, entre eles: alteração do tipo de carregamento; redução na relação altura/largura da fôrma de aço; alteração nas condições de apoio da fôrma; redução do comprimento de cisalhamento $L_{s}$. Segundo PATRICK \& BRIDGE (1994), o método proposto é facilmente adaptado ao cálculo de lajes mistas contínuas e estava sendo desenvolvido para um possível uso na norma australiana sobre o dimensionamento de lajes mistas. A figura 4.8 ilustra o ensaio slip block test.

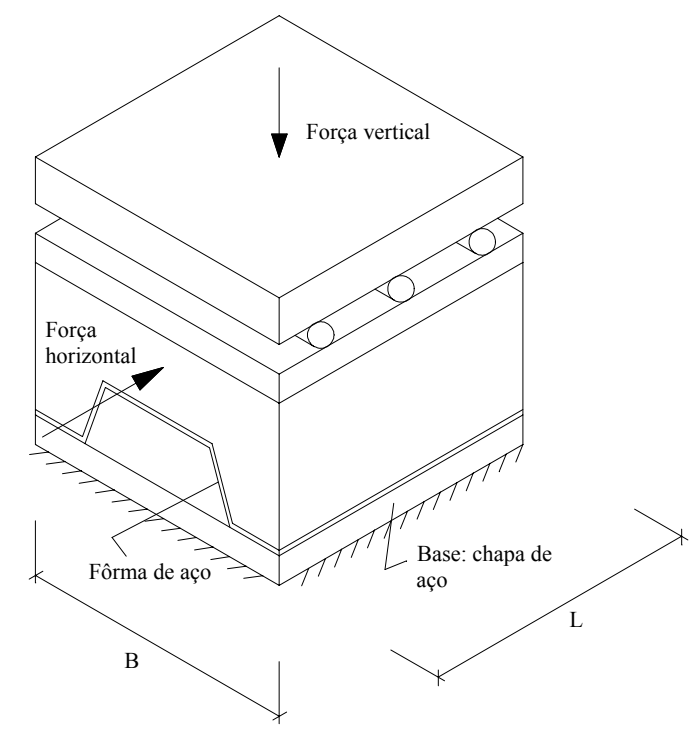

FIGURA 4.8: Esquema típico do ensaio slip block test

\subsection{DIMENSIONAMENTO DE LAJES MISTAS}

Neste item serão descritos os procedimentos de cálculo do EUROCODE 4, o qual aborda o dimensionamento de lajes mistas. Devem ser considerados os seguintes estados limites:

Estados limites últimos:

- Flexão;

- Cisalhamento longitudinal; 
- Cisalhamento vertical;

- Punção.

Estados limites de utilização:

- Deslizamento relativo de extremidade;

- Flecha;

- Fissuração excessiva no concreto.

\subsubsection{ESTADOS LIMITES ÚLTIMOS}

\subsubsection{RESISTÊNCIA À FLEX̃̃O}

$\mathrm{O}$ valor do momento resistente de cálculo $M_{R d}$ em qualquer seção é determinado considerando a plastificação total da seção, limitando-se a tensão de cálculo na fôrma em $f_{y p} / \gamma_{a p}$, onde $f_{y p}$ e $\gamma_{a p}$ são, respectivamente, a resistência ao escoamento e o coeficiente de resistência da fôrma de aço. No caso de momentos negativos, a contribuição da fôrma de aço somente deve ser considerada caso haja continuidade da fôrma.

Para a obtenção da área efetiva da fôrma de aço, deve-se desprezar a largura das mossas, a não ser que se demonstre, através de ensaios, que essa área efetiva seja maior.

O efeito de flambagem local das zonas comprimidas da fôrma de aço é levado em conta utilizando-se relações "largura/espessura" que não superem o dobro dos valores limites dados na tabela 4.2 do EUROCODE 4, para almas pertencentes à classe 1 .

O colapso por flexão pode ser crítico se houver interação completa ao cisalhamento longitudinal na interface entre a fôrma de aço e o concreto, ou seja, ausência de deslizamento relativo de extremidade.

\section{Cálculo do momento resistente:}


$\mathrm{Na}$ determinação do momento resistente de cálculo de uma laje mista, duas situações são possíveis:

\section{1) Linha Neutra Plástica acima da fôrma de aço - Interação Completa}

A figura 4.9 ilustra a distribuição de tensões ao longo da seção transversal da laje mista sob momento positivo.

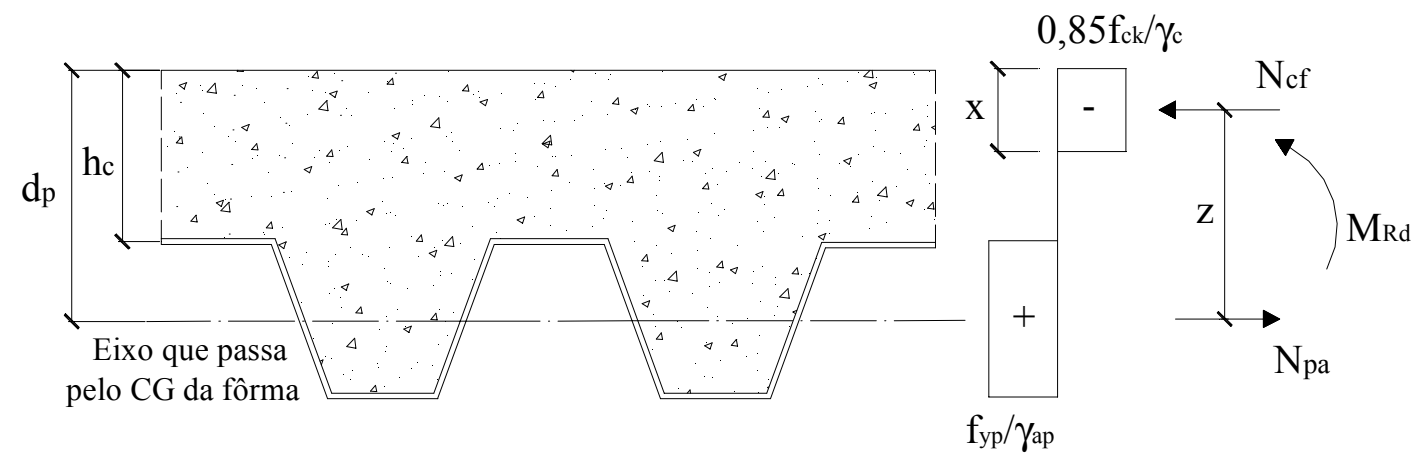

FIGURA 4.9: Distribuição de tensões para momentos positivos: Linha Neutra Plástica acima da fôrma de aço.

Este caso ocorre quando $x \leq h_{c}$.

A resistência ao momento fletor positivo $M_{p, R d}$ é calculada com a seguinte expressão:

$M_{p, R d}=N_{c f}\left(d_{p}-\frac{x}{2}\right)$

onde

$N_{c f}=N_{p a}=\frac{A_{p} f_{y p}}{\gamma_{a p}}$

$A_{p}$ é a área efetiva da fôrma de aço tracionada;

$d_{p}$ é a distância do topo da laje ao eixo de gravidade da fôrma de aço; 
$x$ é a altura da zona comprimida do concreto, dada por $x=\frac{N_{c f}}{b\left(0,85 \frac{f_{c k}}{\gamma_{c}}\right)}$;

$b$ é a largura da seção transversal;

$\gamma_{a p}$ é o coeficiente de resistência do aço da fôrma, igual a 1,1;

$f_{y p}$ é a resistência ao escoamento do aço da fôrma.

2) Linha Neutra Plástica interceptando a fôrma de aço - Interação Completa

Neste caso, recorre-se a uma simplificação de cálculo, onde se despreza o concreto contido na nervura. A figura 4.10 ilustra a distribuição de tensões na seção transversal:

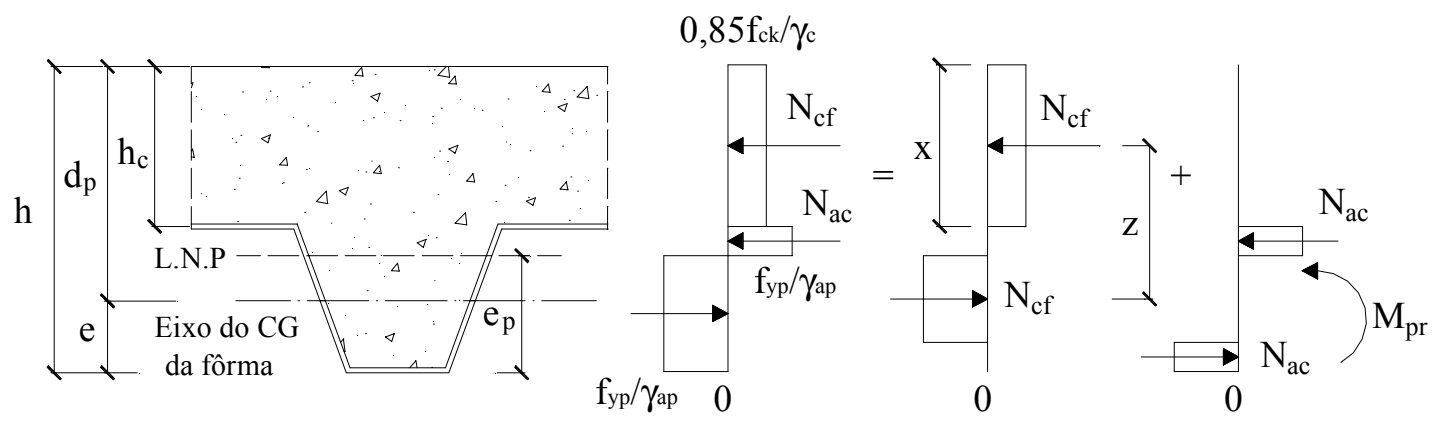

FIGURA 4.10: Distribuição de tensões para momentos positivos: Linha Neutra Plástica interceptando a fôrma de aço.

O momento resistente é calculado com a seguinte expressão:

$M_{p, R d}=N_{c f} z+M_{p r}$

onde

$N_{c f}=b h_{c} \frac{0,85 f_{c k}}{\gamma_{c}}$ 
$z=h-\frac{h_{c}}{2}-e_{p}+\left(e_{p}-e\right) \frac{N_{c f}}{A_{p} \frac{f_{y p}}{\gamma_{a p}}} ;$

$M_{p r}$ é o momento de plastificação reduzido da fôrma de aço, expresso por:

$M_{p r}=1,25 M_{p a}\left(1-\frac{N_{c f}}{A_{p} \frac{f_{y p}}{\gamma_{a p}}}\right) \leq M_{p a} ;$

$M_{p a}$ é o momento de plastificação efetivo da fôrma de aço;

$e_{p}$ é a distância da linha neutra plástica (L.N.P.) à extremidade inferior da fôrma de aço;

$e$ é a distância do eixo de gravidade da fôrma de aço à sua extremidade inferior;

$h$ é a altura total da laje mista.

\subsubsection{RESISTÊNCIA AO CISALHAMENTO LONGITUDINAL}

O deslocamento horizontal relativo excessivo entre a fôrma de aço e o concreto caracteriza o colapso por cisalhamento horizontal. Quando ocorre deslocamento relativo entre os dois materiais, o colapso por flexão não pode ser alcançado. Neste caso, o colapso ocorre com interação parcial ao cisalhamento.

O resistência de cálculo ao cisalhamento horizontal pode ser determinada pelo método empírico “ $m$ - $k$ ” ou pelo método da interação parcial.

Pelo método " $m-k$ ", a resistência de cálculo ao cisalhamento longitudinal $V_{l, R d}$ é obtida através da seguinte relação semi-empírica:

$V_{l, R d}=\frac{b d_{p}\left(\frac{m A_{p}}{b L_{s}}+k\right)}{\gamma_{v s}}$

onde

$m$ e $k$ são constantes empíricas $\left(\mathrm{em} \mathrm{N} / \mathrm{mm}^{2}\right.$ ) obtidas do ensaios associados ao método "m e k", cujos procedimentos encontram-se no item 10.3.1 do EUROCODE 4 
$b$ é a largura efetiva da laje, em mm;

$A_{p}$ em $\mathrm{mm}^{2}$ e $d_{p}$ em mm;

$L_{s}$ é o vão de cisalhamento, em mm;

$\gamma_{v s}$ é o coeficiente de resistência, igual a 1,25.

\subsection{MÉTODO “M-K":}

Este método é considerado internacionalmente como método padrão na determinação da resistência ao cisalhamento longitudinal, utilizando-se uma equação semi-empírica que relaciona a resistência nominal ao esforço cortante com os parâmetros dos testes (vide expressão 4.7). Esses testes baseiam-se no estudo de lajes mistas simplesmente apoiadas, com cargas concentradas distantes à $1 / 4$ do vão da laje. O vão de cisalhamento $L_{s}$, segundo o EUROCODE 4, deve ser tomado igual a L/4. A figura 4.11 ilustra a geometria da laje mista do teste, bem como a disposição do carregamento aplicado e as seções críticas que caracterizam os modos de colapso.

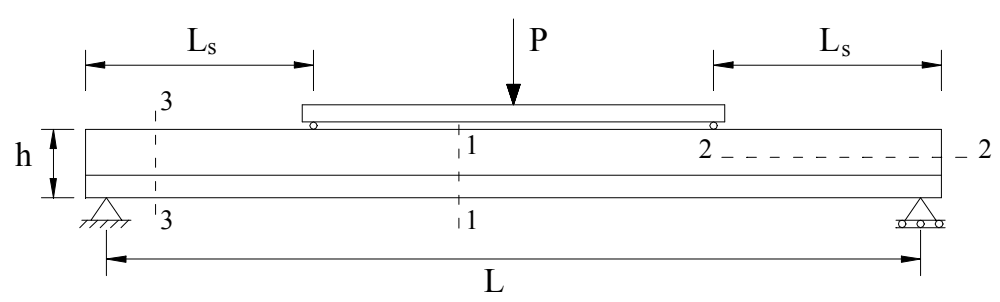

a) Seções críticas da laje mista

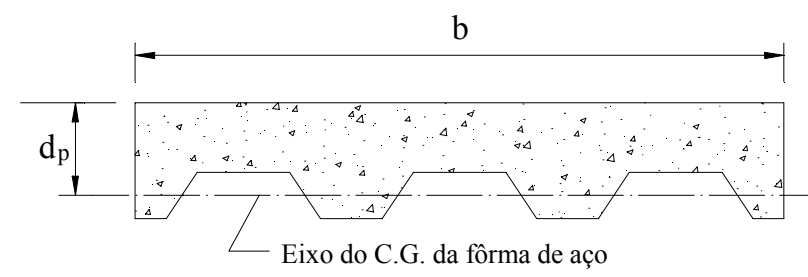

b) Seção transversal da laje mista

FIGURA 4.11: Disposição do carregamento e geometria laje mista-Método " $m-k$ "

Existem três modos possíveis de colapso neste método: 
a) Flexão: seção 1-1;

b) Cisalhamento longitudinal: seção 2-2;

c) Cisalhamento transversal: seção 3-3.

O modo de colapso previsto num teste depende da relação $L_{s}$ e da altura $d_{p}$. Conforme o EUROCODE 4, os resultados devem ser colocados em um gráfico cujas abcissas representem os valores de $A_{p} / b L_{s}$ e cujas ordenadas representem os valores de $V / b L_{s}$, onde $V$ é a força cortante no vão de cisalhamento . As constantes $m$ e $k$ são determinadas através de regressão linear, utilizando o método dos mínimos quadrados. A figura 4.12 ilustra a definição das constantes $m$ e $k$ e os possíveis modos de colapso:

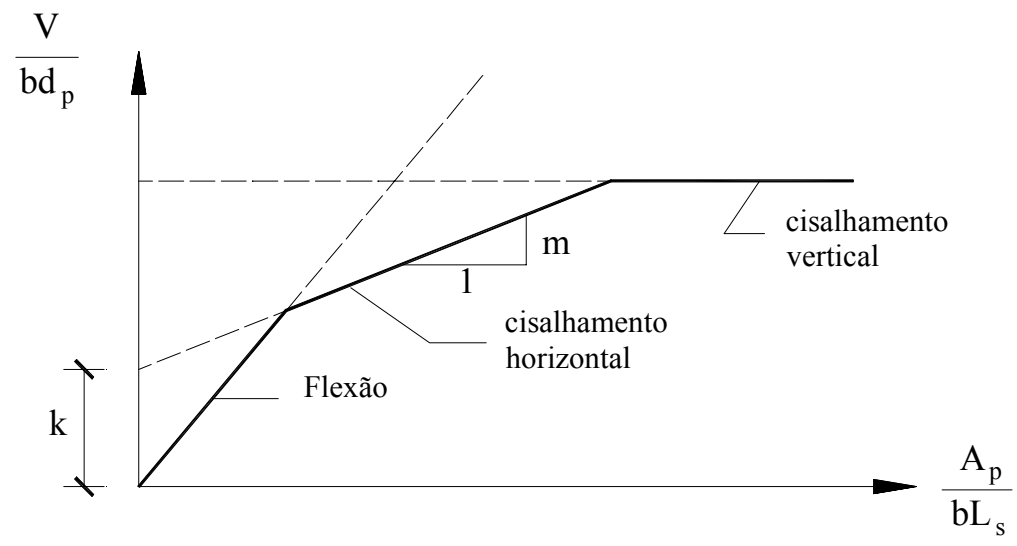

FIGURA 4.12: Definição das constantes m e $k$ e os possíveis modos de colapso.

\subsection{MÉTODO DA INTERAÇÃO PARCIAL:}

De acordo com o EUROCODE 4, este é um método alternativo ao método " $m-k$ " e somente deve ser utilizado em lajes mistas com comportamento dúctil, observado a partir da curva força $\mathrm{x}$ escorregamento e da curva força $\mathrm{x}$ deslocamento do ensaio estático. O comportamento dúctil é caracterizado quando a carga de ruptura excede $10 \%$ da carga que provoca o primeiro deslizamento de extremidade. Caso a carga produza uma flecha no meio do vão que ultrapassa o valor de L/50, considerar-se-á como carga de ruptura aquela que produz uma flecha igual a L/50 no meio do vão. 
Determinação da Resistência de Cálculo ao Cisalhamento $\tau_{u R d}$

Por meio dos resultados de cada ensaio realizado, cujos procedimentos encontram-se no item 10.3 do EUROCODE 4, pode-se determinar a resistência ao cisalhamento.

O diagrama de interação parcial, tal como indica a figura 4.13, deve ser determinado utilizando-se as dimensões e resistências nominais do concreto e da fôrma de aço, obtidos no ensaio. Com relação à resistência à compressão do concreto, pode-se empregar o valor médio $f_{c m}$ de cada grupo ensaiado.

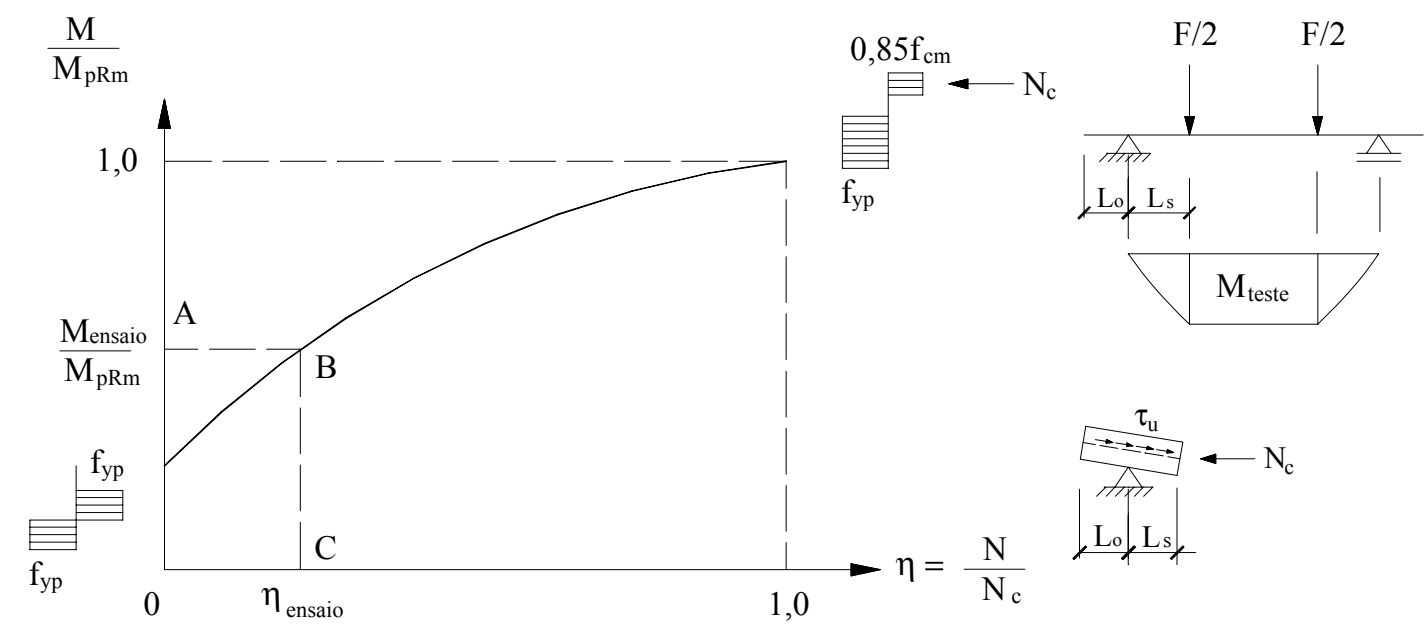

FIGURA 4.13: Determinação do grau de interação parcial ao cisalhamento adaptado do EUROCODE 4 (1992).

Os valores de $M_{p R m}$ e $N_{c f}$ são calculados a partir das equações (4.1) e (4.2) ou (4.3) ou (4.4), conforme for adequado, devendo-se usar dimensões e resistências nominais ao invés de valores de cálculo.

Para construir o diagrama de interação parcial, é necessário variar os valores de $\eta=N_{c} / N_{c f}$ entre 0 e 1 . Atribuindo-se um valor para $\eta$, determina-se a força $N_{c}$. A correspondente relação entre $M$ e $N_{c}$ é dada pela seguinte expressão: 
$M=N_{c} z+M_{p r}$

onde

$$
\begin{aligned}
& z=h-\frac{x}{2}-e_{p}+\left(e_{p}-e\right) \frac{N_{c}}{A_{p} f_{y p}} \\
& x=\frac{N_{c}}{0,85 f_{c m} b} \leq h_{c} \\
& M_{p r}=1,25 M_{p a}\left(1-\frac{N_{c}}{A_{p} f_{y p}}\right) \leq M_{p a}
\end{aligned}
$$

Os valores de $M / M_{p R m}$ podem então ser lançados no gráfico para seus respectivos valores de $\eta$ (entre 0 e 1), determinando assim o diagrama de interação parcial para cada protótipo.

A partir das cargas máximas aplicadas nos ensaios, obtém-se o momento fletor $M_{\text {ensaio }}$ na seção transversal sob o ponto de aplicação da carga na laje, devido à ação aplicada pelo macaco, ao peso próprio da laje e ao peso das vigas que transmitem as cargas.

Na sequência, o valor de $\eta$ para cada ensaio é obtido facilmente através da trajetória A-B-C, conforme indica a figura 4.13.

Uma vez conhecidos os valores de $\eta$ de cada ensaio, calcula-se a resistência última de cisalhamento $\tau_{u}$ para cada protótipo ensaiado, por meio da expressão:

$\tau_{u}=\frac{\eta N_{c f}}{b\left(L_{s}+L_{o}\right)}$

onde

$L_{o}$ é o comprimento do balanço, conforme ilustra a figura 4.13.

A resistência nominal ao cisalhamento $\tau_{u, R k}$ deve ser tomada como o menor valor de $\tau_{u}$ obtido nos ensaios, reduzido de $10 \%$.

A resistência de cálculo ao cisalhamento, portanto, é calculada a partir de $\tau_{u, R k}$, com coeficiente de segurança $\gamma_{v}$ igual a 1,25 : 
$\tau_{u, R d}=\frac{\tau_{u, R k}}{\gamma_{v}}$

Verificação da Resistência ao Cisalhamento Longitudinal

Determinada a resistência de cálculo ao cisalhamento longitudinal $\tau_{u, R d}$, é possível construir o diagrama de interação parcial de cálculo. Neste diagrama, o valor do momento resistente de cálculo $M_{R d}$ de uma seção transversal, situada a uma distância $L_{x}$ do apoio mais próximo, é definido em função de $L_{x}$. A força de interação parcial na laje $N_{c}$, em uma seção transversal qualquer, distante $L_{x}$ do apoio, é calculada pela expressão:

$N_{c}=b L_{x} \tau_{u, R d}$

Calcula-se, dessa forma, o momento resistente de cálculo $M_{R d}$ utilizando-se as equações (4.8) à (4.11), relativas ao método de interação parcial. A figura 4.14 ilustra o diagrama de interação parcial de cálculo.

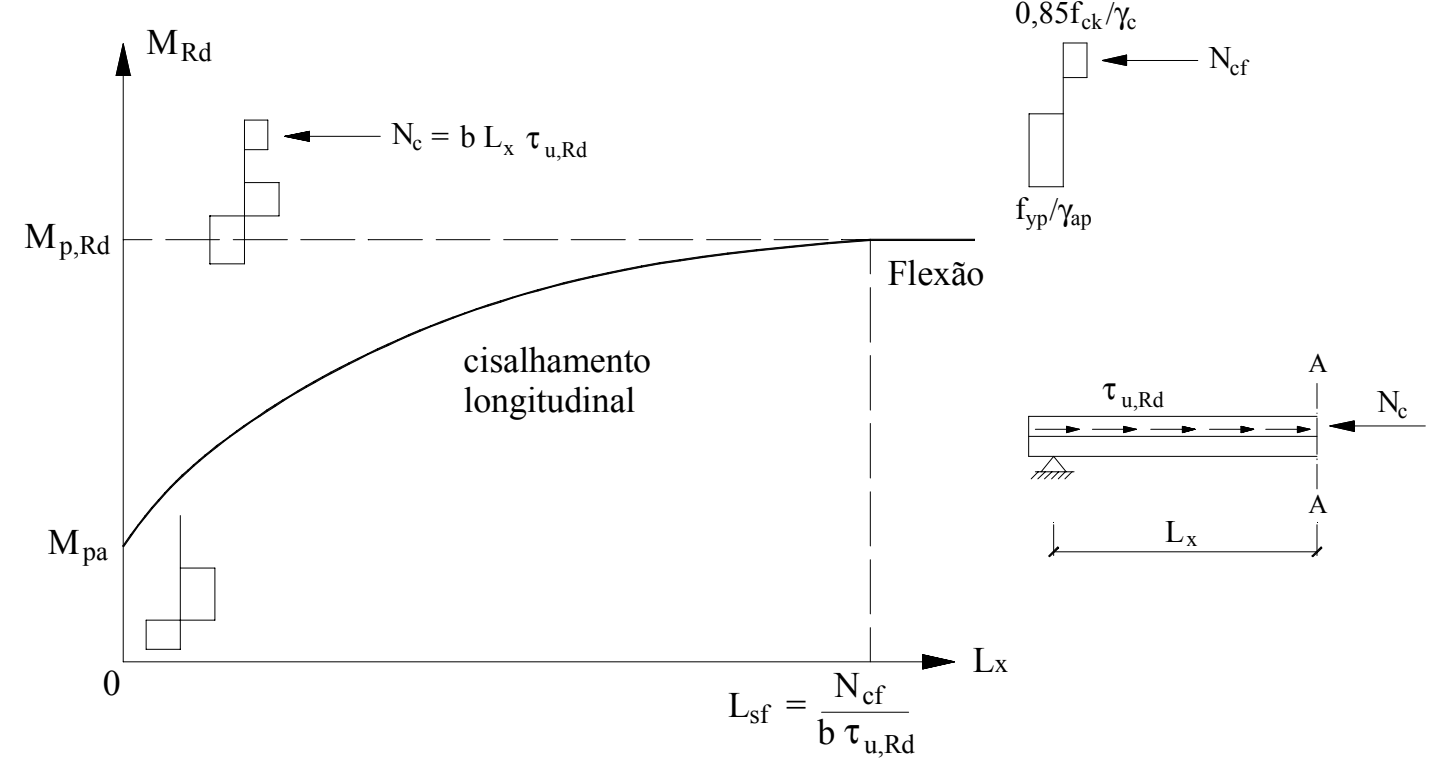

FIGURA 4.14: Diagrama de interação parcial de cálculo 
O comprimento $L_{s f}$, dado pela expressão

$$
L_{s f}=\frac{N_{c f}}{b \tau_{u, R d}}
$$

representa o comprimento mínimo que deve assumir $L_{x}$ para que a interação ao cisalhamento seja completa. Portanto, a partir da figura 4.14, observa-se que duas situações são possíveis:

a) Para $L_{x} \geq L_{s f}$, a interação ao cisalhamento é completa; portanto, o colapso ocorre por flexão;

b) Para $L_{x}<L_{s f}$, a interação ao cisalhamento é parcial; portanto o colapso ocorre por cisalhamento longitudinal.

No dimensionamento, a curva do momento fletor de cálculo $M_{s d}$, em qualquer seção transversal, não deve situar-se acima da curva do momento resistente de cálculo $M_{R d}$. A figura 4.15 ilustra o procedimento de verificação da resistência ao cisalhamento para duas lajes, com diferentes tipos de carregamento e de vão.

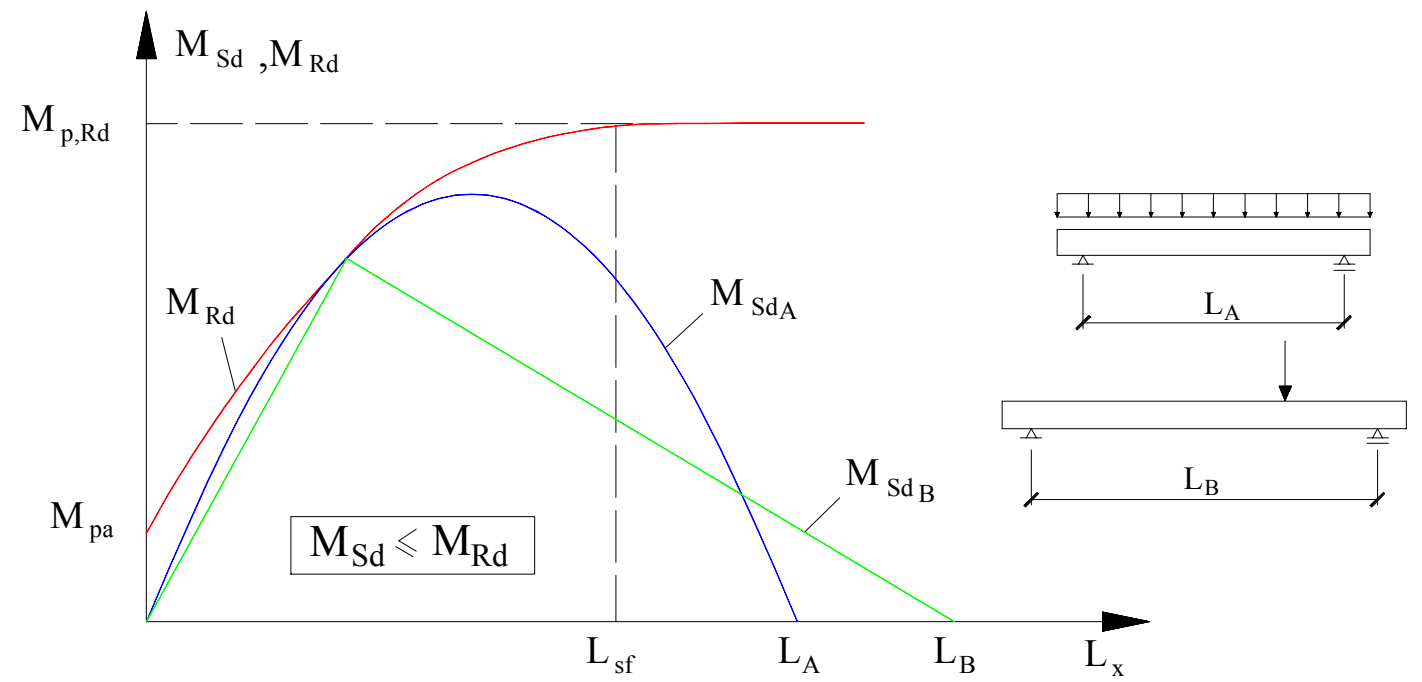

FIGURA 4.15: Verificação da resistência ao cisalhamento 


\subsubsection{RESISTÊNCIA AO CISALHAMENTO TRANSVERSAL}

Segundo JOHNSON (1994), o cisalhamento transversal costuma ser mais crítico em lajes cuja relação altura/vão são pequenas. Os métodos de cálculo da resistência ao cisalhamento transversal são baseados nos procedimentos utilizados na verificação do cisalhamento em vigas $\mathrm{T}$ de concreto armado. A resistência ao cisalhamento vertical é fornecida, principalmente, pelas nervuras de concreto.

A resistência de cálculo ao cisalhamento transversal $V_{v, R d}$ de uma laje mista, cuja largura $b$ é igual a distância entre centros de nervuras, determina-se por:

$$
V_{v, R d}=\frac{b_{o}}{b} d_{p} \tau_{R d} k_{v}(1,2+40 \rho)
$$

onde

$b_{o}$ é a largura média das nervuras de concreto;

$\tau_{R d}$ é a resistência básica ao cisalhamento, igual a $0,25 f_{c k t} / \gamma_{c}$;

$f_{c k t}=f_{c k t, 0,05}$, o qual corresponde a um valor característico da resistência à tração do concreto da laje, conforme o item 3.1.2 do EUROCODE 4: Parte 1-1;

$\rho$ é um coeficiente que leva em consideração a pequena contribuição da fôrma de aço, dado por $\rho=\frac{A_{p}}{b_{o} d_{p}}$;

$A_{p}$ é a área da fôrma de aço que se encontra sob tração, dentro da largura $b_{o}$;

$K_{v}$ é um coeficiente que leva em consideração um acréscimo na resistência devido ao confinamento do concreto, expresso por $k_{v}=\left(1,6-d_{p}\right) \geq 1$, com $d_{p} \mathrm{em} \mathrm{m}$.

\subsubsection{PUNÇÃO}

O efeito de punção geralmente é mais crítico em lajes de pequena espessura submetidas a cargas pontuais. O colapso ocorre em um "perímetro crítico", definido através de um ângulo de $45^{\circ}$, a partir da superfície de aplicação da carga até eixo de gravidade da fôrma de aço, conforme ilustra a figura 4.16. 
a)

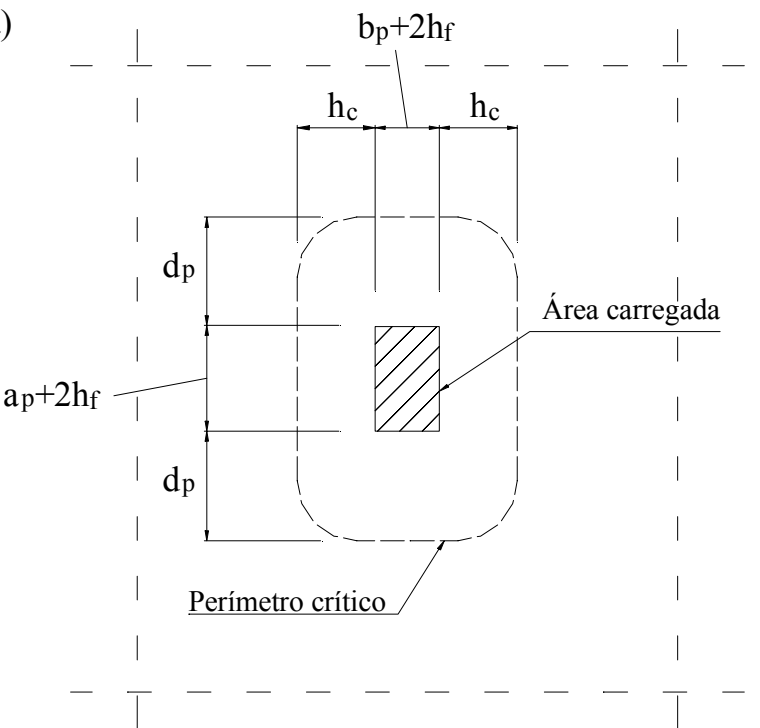

b)

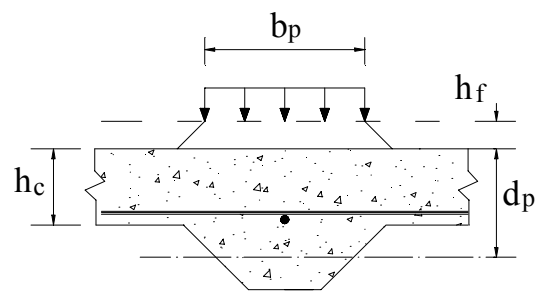

FIGURA 4.16: Perímetro crítico para o cisalhamento por punção

A resistência de cálculo à punção $V_{p, R d}$ de uma laje mista submetida a uma área carregada de dimensões $a_{p} \mathrm{x} b_{p}$ (ver figura 4.16), é determinada por:

$V_{p, R d}=C_{p} h_{c} \tau_{R d} k_{v}(1,2+40 \rho)$

onde

$h_{c}, \tau_{R d}, k_{v}$ e $\rho$ conforme já definido anteriormente;

$C_{p}$ é o perímetro crítico. Com base na figura 4.16, pode-se calcular o perímetro crítico através de:

$$
C_{p}=2 \pi h_{c}+2\left(2 d_{p}+a_{p}-2 h_{c}\right)+2 b_{p}+8 h_{f}
$$

onde

$b_{p}$ é a dimensão da base da carga concentrada perpendicular às nervuras da fôrma de aço, em mm;

$a_{p}$ é a dimensão da base da carga concentrada paralela às nervuras da fôrma de aço, em mm;

$h_{f}$ é a altura da camada de revestimento do piso, em $\mathrm{mm}$. 


\subsubsection{ESTADOS LIMITES DE UTILIZAÇÃO}

\subsubsection{DESLIZAMENTO RELATIVO DE EXTREMIDADE}

Segundo o EUROCODE 4, o deslizamento relativo de extremidade deve ser levado em conta como estado limite de utilização quando a carga aplicada provoca um deslizamento horizontal maior ou igual a $0,5 \mathrm{~mm}$ entre a fôrma de aço e o concreto. $\mathrm{O}$ valor desta carga, denominada carga de deslizamento de extremidade inicial, é obtido a partir de ensaios. (conforme item 10.3 do EUROCODE 4).

O EUROCODE 4 recomenda que as cargas de serviço não devem ultrapassar a carga de deslizamento inicial dividida por 1,2. Caso o deslocamento horizontal de extremidade ultrapasse $0,5 \mathrm{~mm}$ para uma carga inferior à carga de cálculo dividida por 1,2, então deve-se dispor de ancoragens de extremidade, do tipo Stud Bolt, por exemplo.

\subsubsection{FLECHA}

Segundo JOHNSON (1994), quando as lajes mistas são calculadas como biapoiadas e não estão escondidas por forro falso, a flecha pode governar o dimensionamento da laje.

A verificação de flecha pode ser omitida quando:

a) A relação $d_{p} / L$ não excede os seguintes valores:

25 para lajes simplesmente apoiadas;

32 para vãos externos e 35 para vãos internos de uma laje contínua;

10 para lajes em balanço.

b) Quando a carga de deslizamento inicial dos ensaios excede 1,2 vezes a carga de serviço. 
Não é necessário incluir a flecha da fôrma de aço devido ao seu peso próprio e ao concreto fresco na verificação da laje mista.

A verificação da flecha, segundo o EUROCODE 4, ainda depende se o vão da laje é interno ou externo. Para vãos internos, devem ser feitas duas aproximações:

a) O momento de inércia a ser utilizado na determinação de flechas é igual a média aritmética dos momentos de inércia da seção "fissurada" e da seção "não fissurada";

b) O efeito da fluência pode ser considerado através do valor médio dos coeficientes de homogeneização para efeitos de longa e curta duração. Como valor prático, pode tomar-se tal coeficiente médio como $n=E / 0,5 E_{c}$.

Nos vãos externos, o deslizamento de extremidade pode ter um efeito significativo sobre a flecha. Quando o comportamento é "não-dúctil" (ver figura 4.17a), o deslizamento inicial de extremidade e a ruptura podem ser coincidentes. Por outro lado, quando o comportamento é "semi-dúctill", o deslizamento de extremidade pode afetar também a flecha. Por esse motivo, recomenda-se consultar resultados de ensaios em lajes mistas a fim de estabelecer o comportamento em regime de utilização para vãos externos.

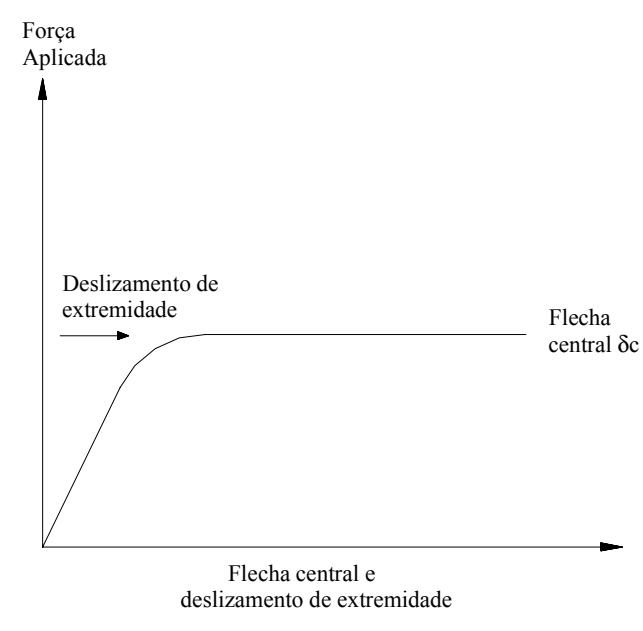

a) Comportamento "não dúctil"

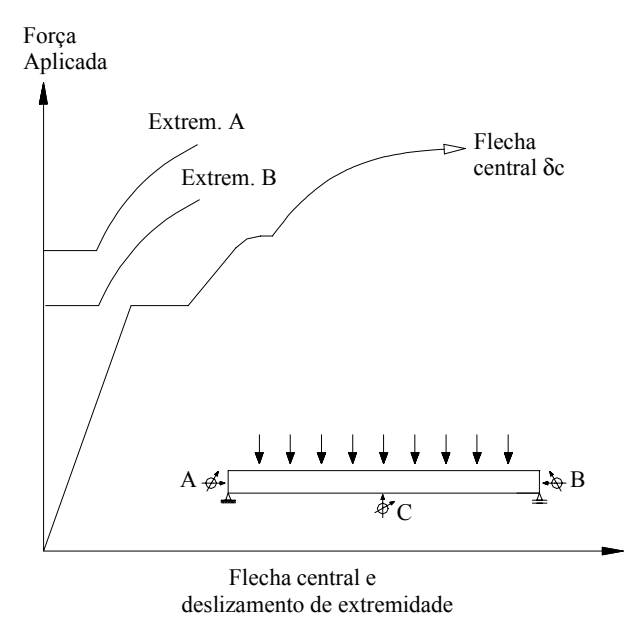

b) Comportamento "semi-dúctil"

FIGURA 4.17: Comportamento do deslizamento relativo de extremidade para vãos externos 


\subsubsection{FISSURAÇÃO NO CONCRETO}

A superfície inferior da laje é protegida pela fôrma de aço. Portanto, as fissuras possivelmente ocorrerão na superfície superior, sobre os apoios, se esta for contínua.

O controle da abertura de fissuras do concreto pode ser realizado baseandose nas recomendações do EUROCODE 2 (1991): "Projeto de Estruturas de Concreto"

Quando lajes contínuas são dimensionadas como simplesmente apoiadas, a área da armadura longitudinal mínima, na direção paralela às nervuras, necessária para o controle da fissuração do concreto deve ser igual a:

- $\quad$ 0,4\% da área de concreto acima da fôrma de aço, para construção escorada;

- $\quad 0,2 \%$ da área de concreto acima da fôrma de aço, para construção não escorada.

Essas armaduras devem estar localizadas na face superior da laje, com recobrimento mínimo de $20 \mathrm{~mm}$.

\section{Considerações sobre Cargas Concentradas Pontuais e Lineares}

Pelo fato do sistema de lajes mistas ser calculado como laje armada apenas em uma única direção, a capacidade das lajes mistas em suportar cargas lineares, tais como alvenarias, ou cargas pontuais é limitada.

O EUROCODE 4 apresenta algumas regras para a determinação da largura efetiva das lajes mistas no caso de aplicação de cargas concentradas pontuais ou lineares, na verificação da resistência à flexão e ao cisalhamento .

Para cargas concentradas pontuais ou lineares paralelas ao vão da laje, considera-se que essas estão distribuídas em uma largura $b_{m}$, medida sobre a parte superior das nervuras da fôrma de aço, conforme ilustra a figura 4.18. 


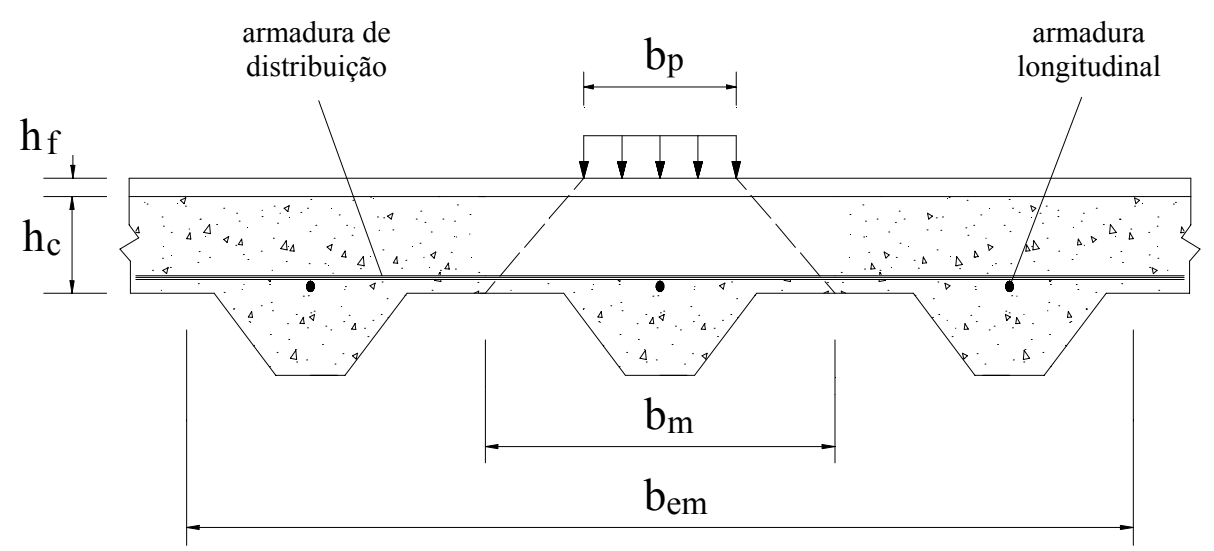

FIGURA 4.18: Distribuição da carga concentrada

A largura $b_{m}$ é expressa por:

$b_{m}=b_{p}+2\left(h_{c}+h_{f}\right)$

onde

$b_{p}$ é a largura da carga concentrada, medida na direção perpendicular ao vão da laje; $h_{f}$ é a espessura da camada de revestimento, caso exista.

Para cargas concentradas lineares perpendiculares à direção do vão da laje, pode-se utilizar a expressão (4.18) para a determinação de $b_{m}$, substituindo-se $b_{p}$ pelo comprimento de aplicação da carga concentrada, medido na direção perpendicular ao vão da laje.

A largura efetiva considerada no cálculo da resistência da seção é determinada levando-se em conta duas situações:

- Flexão e cisalhamento longitudinal: A largura efetiva $b_{e m}$ é dada por:

- Para lajes mistas simplesmente apoiadas e vãos externos de lajes contínuas:

$$
b_{e m}=b_{m}+2 L_{p}\left(1-\frac{L_{p}}{L}\right) \leq \text { largura da laje }
$$


- Para vãos internos de lajes contínuas

$$
b_{e m}=b_{m}+1,33 L_{p}\left(1-\frac{L_{p}}{L}\right) \leq \text { largura da laje }
$$

- Cisalhamento transversal: A largura efetiva $b_{e v}$ é dada por:

$$
b_{e v}=b_{m}+L_{p}\left(1-\frac{L_{p}}{L}\right) \leq \text { largura da laje }
$$

onde

$L_{p}$ é a distância do centro da carga ao apoio mais próximo;

$L$ é o vão da laje.

A fim de assegurar a distribuição das cargas lineares ou pontuais sobre a largura efetiva, deve-se colocar uma armadura de distribuição acima da fôrma de aço, calculada para momentos fletores transversais, conforme prescreve $o$ EUROCODE 2 (1991).

Uma armadura de distribuição igual ou maior a $0,2 \%$ da área de concreto acima das nervuras da fôrma pode ser utilizada, sem a necessidade de cálculo, caso as cargas nominais não superem os seguintes valores:

- $\quad$ carga concentrada: $7,5 \mathrm{kN}$;

- carga distribuída: $5,0 \mathrm{kN} / \mathrm{m}^{2}$.

A disposição dessa armadura, bem como os comprimentos mínimos de ancoragem, também são estabelecidos de acordo com o EUROCODE 2 (1991).

$\mathrm{Na}$ ausência da armadura de distribuição, as larguras efetivas consideradas no cálculo do momento e do cisalhamento, quando da presença de cargas concentradas, não devem ser superiores a $b_{m}$. 


\subsection{INTRODUÇÃO}

Os pilares mistos, de maneira geral, são constituídos por um ou mais perfis de aço, preenchidos ou revestidos de concreto.

Os pilares mistos revestidos inicialmente surgiram da necessidade de proteger os perfis de aço contra a ação nociva do fogo, onde o concreto se encarregaria de fornecer tal proteção.

Posteriormente, pensou-se em utilizar o concreto como material de preenchimento para perfis tubulares, surgindo assim os pilares mistos preenchidos.

A combinação dos materiais aço e concreto em pilares mistos pode propiciar algumas vantagens. Além da proteção ao fogo e do aumento da resistência do pilar, essa combinação contribui para um aumento na rigidez da estrutura aos carregamentos horizontais devido ao vento e às solicitações decorrentes de sismos. A ductilidade é outro ponto que diferencia os pilares mistos, os quais apresentam um comportamento mais "dúctil" quando comparados com os pilares de concreto armado isolados.

Existem também outras vantagens, tal como a ausência de fôrmas, no caso de pilares mistos preenchidos, possibilitando a redução de custos com materiais e mãode-obra.

O emprego de pilares mistos tem sido uma tendência, principalmente em edifícios de andares múltiplos, em diversos países europeus, americanos e asiáticos. No Brasil, entretanto, sua utilização ainda é restrita a poucas obras. 


\subsection{CLASSIFICAÇÃO DE PILARES MISTOS}

Os pilares mistos são classificados em função da posição em que o concreto ocupa na seção mista. A figura 5.1 ilustra algumas seções típicas de pilares.

Os pilares mistos revestidos caracterizam-se pelo envolvimento, por completo, do elemento estrutural em aço, conforme ilustra a figura 5.1 a). A presença do concreto como revestimento, além de propiciar maior resistência, impede a flambagem local dos elementos da seção de aço, além de fornecer maior proteção ao fogo e à corrosão do pilar de aço. A principal desvantagem desse tipo de pilar é a necessidade de utilização de fôrmas para a concretagem, tornando sua execução mais trabalhosa, quando comparada ao pilar misto preenchido.

Os pilares mistos parcialmente revestidos caracterizam-se pelo não envolvimento completo da seção de aço pelo concreto, conforme ilustra a figura 5.1 b). O EUROCODE 4 é a primeira norma a abordar esse tipo de pilar.

Os pilares mistos preenchidos são elementos estruturais formados por perfis tubulares, preenchidos com concreto de qualidade estrutural, conforme a figura $5.1 \mathrm{c}$ ) e d). A principal vantagem desse tipo de pilar é que este dispensa fôrmas e armadura. Para os pilares preenchidos circulares, é possível ainda a consideração do efeito de confinamento do concreto na resistência do pilar misto. 

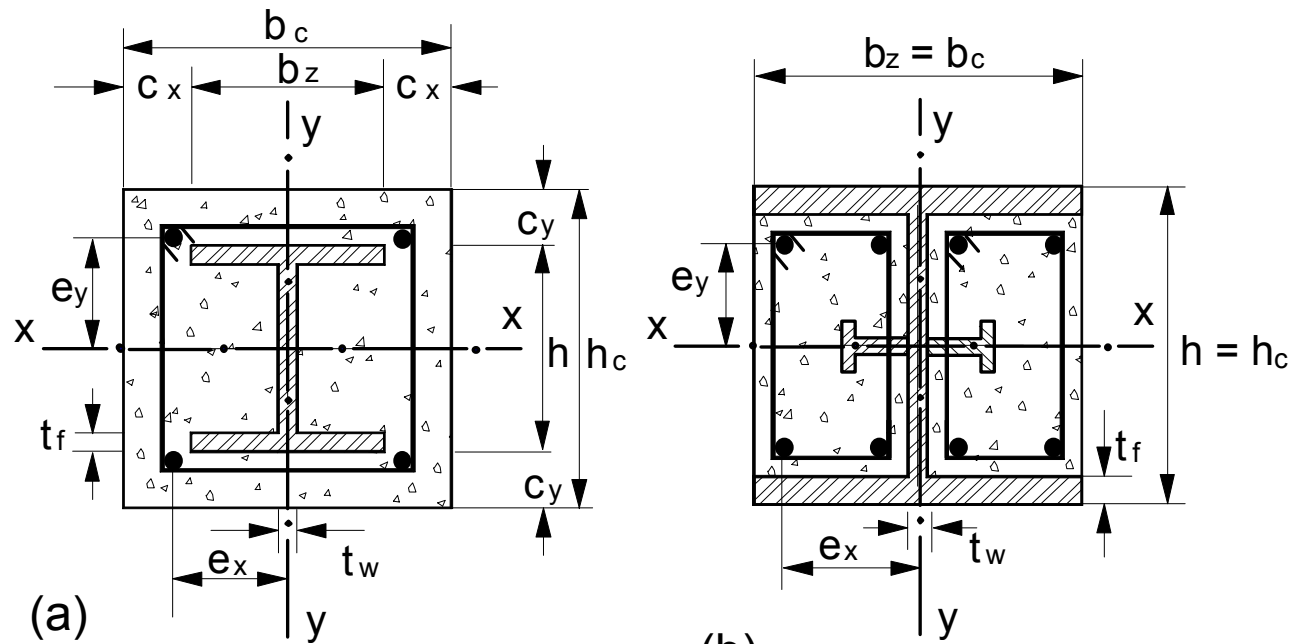

(b)
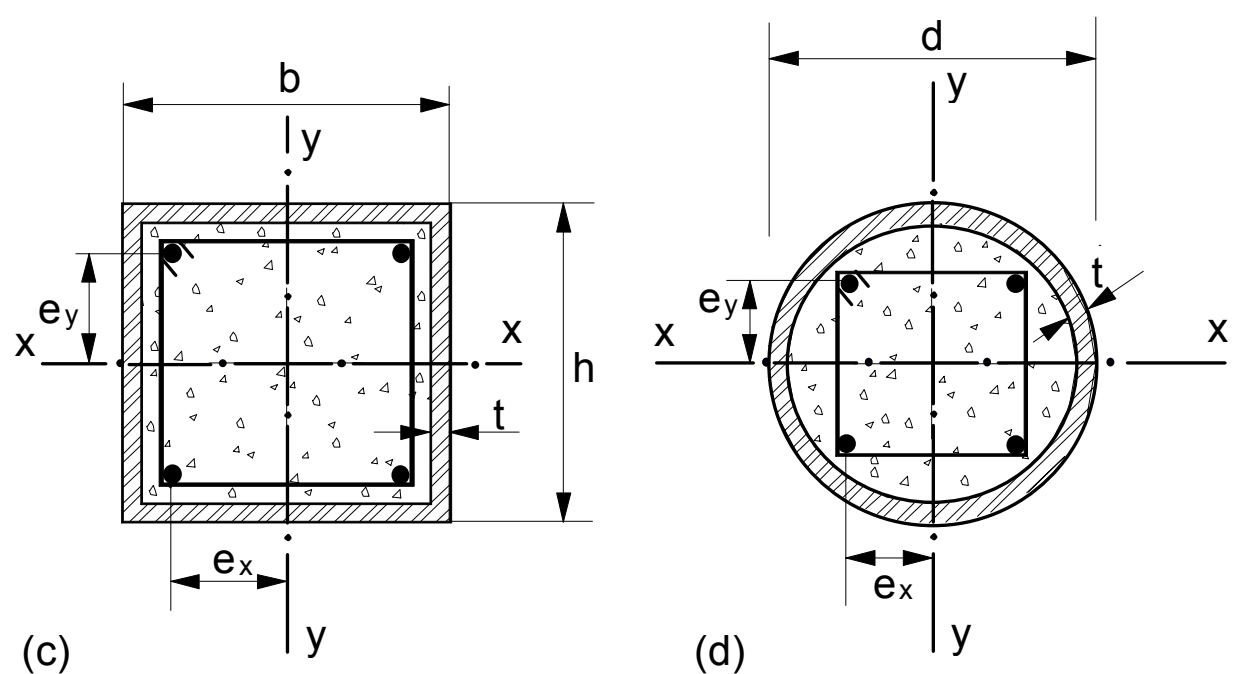

FIGURA 5.1: Exemplos de seções típicas de pilares mistos e dimensões características

\subsection{ASPECTOS CONSTRUTIVOS}

\subsubsection{SEQUÊNCIA CONSTRUTIVA}

A sequência construtiva de um edifício constituído por pilares mistos, em particular os pilares preenchidos de concreto, deve ser considerada cuidadosamente tanto pelo engenheiro calculista quanto pelo responsável pela execução da obra. Vale ressaltar que a estabilidade e a resistência finais frente às ações horizontais do vento não são imediatamente atingidas até o endurecimento do concreto. 
Segundo VALLENILLA \& BJORHOVDE (1990), podem ocorrer problemas de estabilidade do edifício se um número elevado de pavimentos for montado sem a correspondente concretagem, além de sobrecarregar os pilares de aço dos primeiros pavimentos. É por esta razão que se deve limitar o número de pavimentos por etapa de concretagem, durante a fase construtiva. Por outro lado, se as atividades relacionadas com a montagem da estrutura metálica e a concretagem estiverem muito próximas no tempo, poderá ocorrer uma perda da eficiência na construção.

VALLENILLA \& BJORHOVDE (1990) propõem que o sistema estrutural final do edifício seja formado por pórticos mistos nos primeiros pavimentos, por vigas mistas nos pavimentos intermediários, e por elementos de aço isolados nos últimos pavimentos, conforme ilustra a figura 5.2. A proposição de utilização de pórticos mistos nos primeiros pavimentos é obvia, pois as solicitações são maiores.

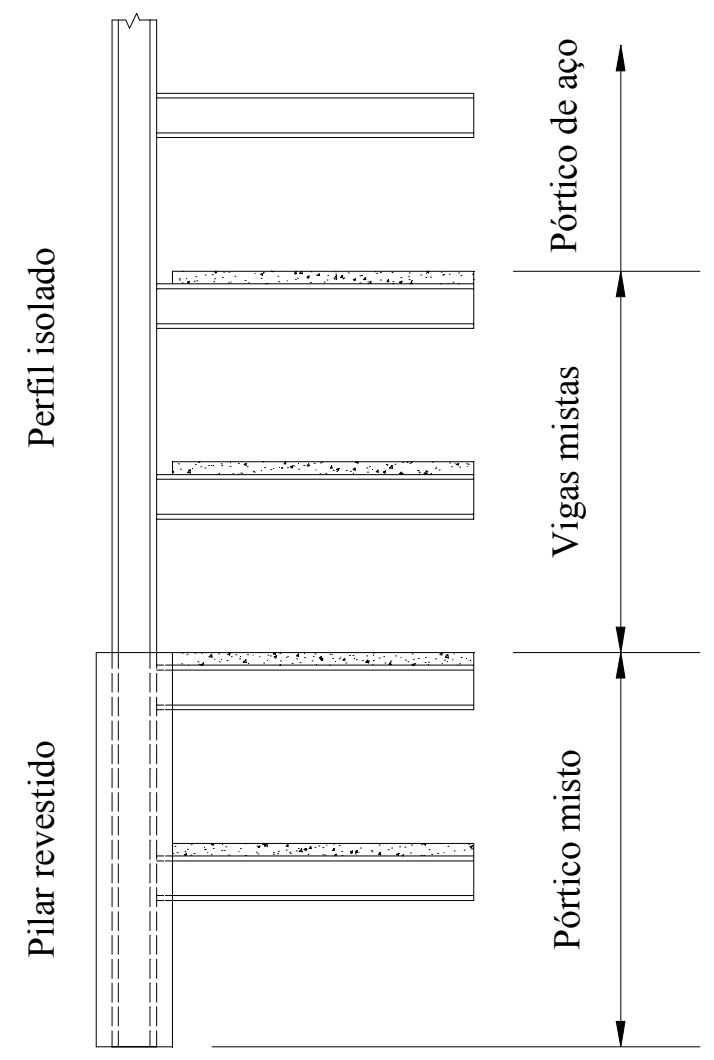

FIGURA 5.2: Sistema estrutural final em pórticos mistos, segundo a proposta de VALLENILLA \& BJORHOVDE (1990) 
É importante notar que, embora seja necessário garantir a estabilidade da estrutura e a segurança dos trabalhadores durante o período de montagem, as normas que tratam do projeto de pilares mistos apresentam praticamente nenhuma informação quanto à fase construtiva desses elementos.

A técnica construtiva utilizada em edifícios de múltiplos andares que empregam pilares mistos preenchidos em seu sistema estrutural inicia-se com a fixação dos perfis tubulares e das vigas de aço, com posterior lançamento de concreto para o interior dos tubos. UY \& DAS (1997) salientam que reduzir ao máximo possível o número de concretagens, respeitando-se os limites de resistência do pilar de aço isolado na fase de execução, é um procedimento vantajoso nesses tipos de edifícios.

Alguns exemplos podem ser mencionados com relação ao número de pavimentos montados para cada operação de concretagem. No edifício Casselden Place, localizado em Melbourne, na Austrália, realizou-se a montagem de seis pavimentos para cada operação de concretagem, resultando em um total de sete operações. No edifício Commonwealth Center, também em Melbourne, realizou-se um total de doze operações de concretagem, uma para cada quatro pavimentos montados.

UY \& DAS (1997) ainda destacam que o perfil tubular de aço, devido à presença do concreto fresco, encontra-se submetido a uma pressão hidrostática lateral. Esta pressão hidrostática, que cresce com o número de pavimentos concretados, pode causar deslocamentos laterais excessivos, devendo-se, portanto, limitar, de maneira adequada, a esbeltez da parede do tubo, a fim de atender as condições de deslocamentos admissíveis. Uma maneira proposta por UY \& DAS (1997) para reduzir esses deslocamentos é lançar mão de um escoramento dos perfis tubulares a meia altura. As vantagens e a eficiência dessa solução são questionáveis, necessitando ser melhor analisadas, pois a opção de não se escorar o pilar pode ser ainda mais atrativa. 


\subsubsection{LIGAÇÕES ENTRE VIGAS E PILARES MISTOS}

Com relação aos pilares mistos preenchidos, os detalhes de ligação entre viga e pilar são diversos, podendo-se dispor tanto de ligações flexíveis quanto de ligações rígidas, semelhantes às usualmente utilizadas na construção metálica. FIGUEREDO (1998), como exemplo, ilustrou dois tipos de ligações normalmente empregadas entre um pilar misto revestido e uma viga mista, conforme a figura 5.3:

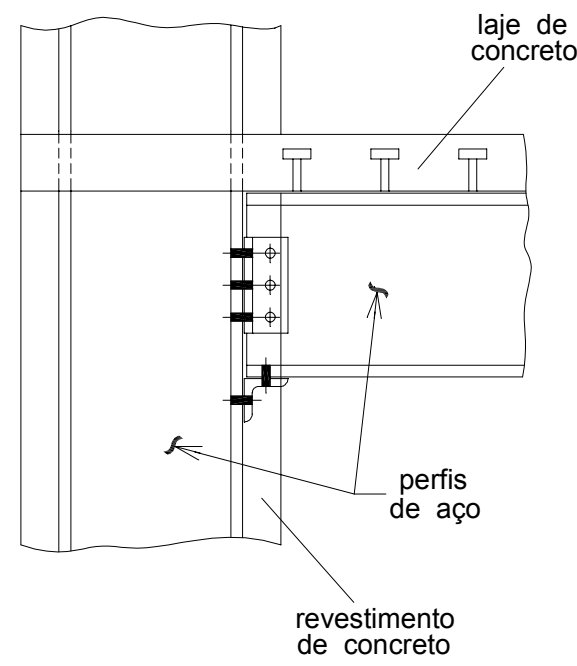

Detalhe 1

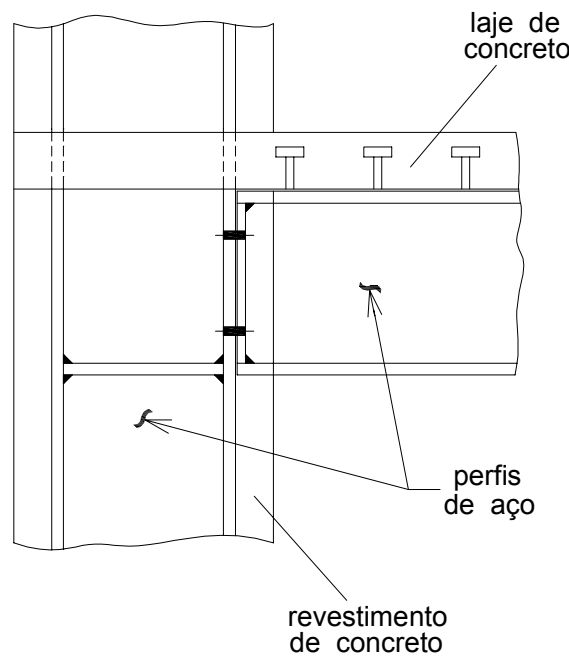

Detalhe 2

FIGURA 5.3: Detalhes de ligações de pilares mistos revestidos com vigas mistas

As ligações viga-pilar, no caso de pilares mistos preenchidos, são usualmente feitas por meio da soldagem direta da viga de aço ao perfil tubular. AZIZINAMINI \& PRAKASH (1993), entretanto, ressaltam alguns motivos pelos quais se deve evitar esses tipos de ligações. A primeira é a possibilidade de separação entre perfil tubular e o núcleo de concreto, devido à transferência de tensões de tração ao perfil. Outro inconveniente é que esses tipos de ligações induzem a concentrações de tensões que podem comprometer o efeito de confinamento do concreto e, por conseqüência, afetar o dimensionamento, pois este efeito é favorável à resistência do pilar.

AZIZINAMINI \& PRAKASH (1993) sugerem, como alternativa às ligações realizadas com soldagem direta no pilar, dois outros tipos de ligações, os quais foram 
objeto de estudo analítico e experimental. Esses dois tipos de ligações apresentam as seguintes características:

- Ligação tipo A: As forças são transmitidas para o núcleo de concreto por meio de parafusos que atravessam o perfil tubular e ficam ancorados no concreto (chumbadores), conforme ilustrado na figura 5.4 a). Neste caso, o elemento de ligação pode ser pré-conectado em fábrica. A resistência deste tipo de ligação é limitada pela resistência ao arrancamento dos parafusos e pelos efeitos locais no perfil tubular. Uma outra variação deste mesmo tipo de ligação é indicada pela figura $5.4 \mathrm{~b}$ ), onde o elemento de aço penetra no núcleo de concreto, ficando ancorado neste. A resistência desta ligação também é limitada pela resistência ao arrancamento e pelos efeitos locais no tubo.

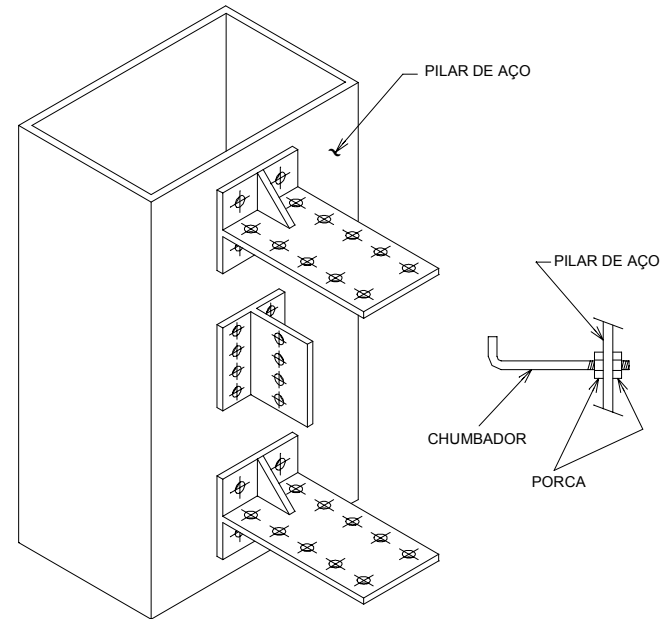

a)

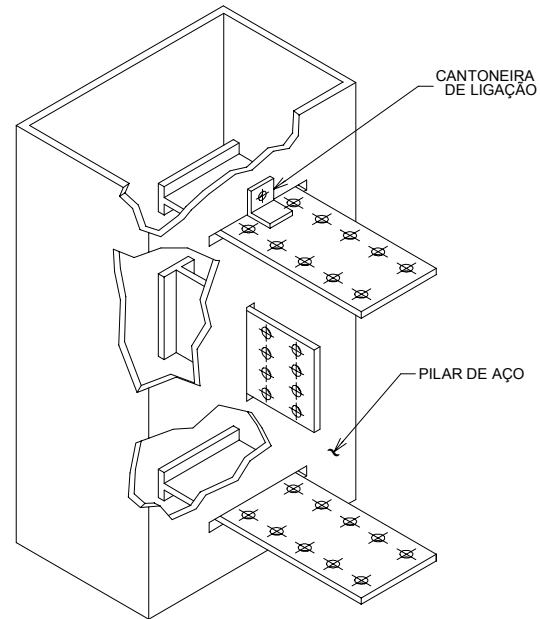

b)

FIGURA 5.4: Esquema de ligações tipo A, investigadas por AZIZINAMINI \& PRAKASH (1993)

- Ligação tipo B: A viga de aço passa completamente pelo pilar, conforme o esquema da figura 5.5. Uma barra de aço pode ser soldada no perfil tubular, atravessando-o e deixando para fora do tubo ainda um trecho cujo comprimento possibilite a fixação da viga em campo, formando assim uma peça única em forma de cruz. O desempenho deste tipo de ligação foi estudado tanto 
teoricamente, empregando a análise de elementos finitos, quanto experimentalmente.

Este último tipo de ligação, embora pareça interessante, deve ser melhor estudado, principalmente no que diz respeito a dois aspectos: a forma de manter os elementos na posição correta durante a execução (antes da concretagem) e a eficiência do mecanismo de transferência de esforços da viga para o concreto do pilar.

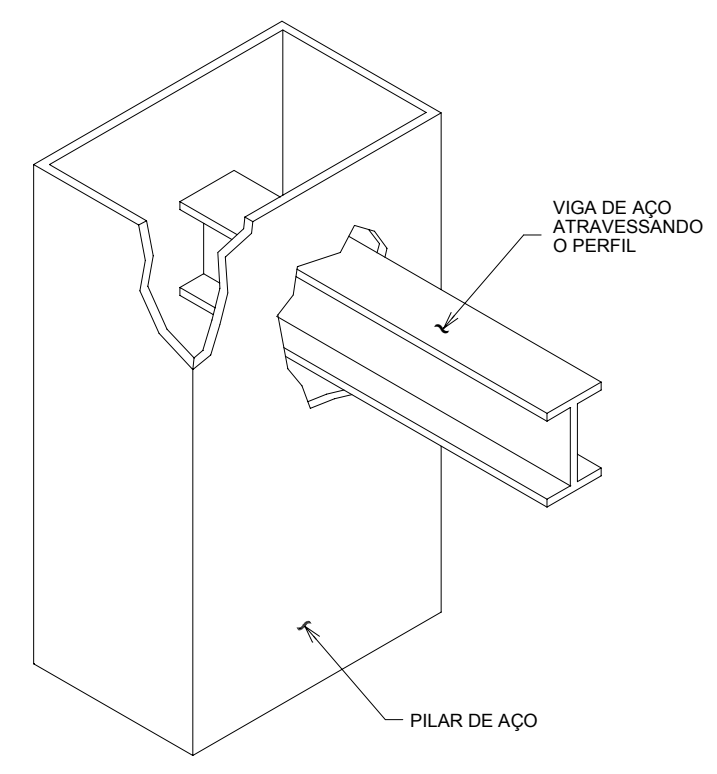

FIGURA 5.5: Esquema de ligação tipo B, investigada por AZIZINAMINI \& PRAKASH (1993)

\subsubsection{SEÇÃO TRANSVERSAL}

\section{Recobrimento}

As normas recomendam para os pilares mistos revestidos um recobrimento mínimo de concreto. Esse recobrimento tem por finalidade promover uma transmissão adequada das forças cisalhantes por aderência, proteger o perfil de aço contra a corrosão e aumentar a resistência ao fogo do pilar. 
O EUROCODE 4 (1992), assim como a norma brasileira NBR 14323 (1999), recomendam, além um recobrimento mínimo de $40 \mathrm{~mm}$ nas duas direções, as seguintes condições:

$$
\begin{aligned}
& c_{y} \leq 0,3 h \quad \text { e } \quad c_{y} \geq b_{f} / 6 \quad\left(c_{x}, c_{y} \text { e } h \text { indicados na figura 5.1 }\right) \\
& c_{x} \leq 0,4 b_{f}
\end{aligned}
$$

A norma britânica BS 5400: Parte 5 (1979) e a norma americana AISC-LRFD (1994) recomendam um recobrimento mínimo de $50 \mathrm{~mm}$ e $40 \mathrm{~mm}$, respectivamente.

\section{Armaduras longitudinal e transversal}

Em pilares mistos preenchidos, em geral, não é necessária a colocação de armadura longitudinal. Entretanto, para os pilares revestidos e parcialmente revestidos, deve-se dispor tanto de armadura longitudinal quanto de armadura transversal. As normas apresentam recomendações com relação à armadura mínima a ser utilizada nesses casos. Em alguns casos, para satisfazer requisitos de proteção contra incêndio, são necessárias maiores taxas de armadura longitudinal.

O EUROCODE 4, assim como a norma brasileira NBR 14323, recomendam uma armadura longitudinal mínima de $0,3 \%$ da área da seção de concreto, não considerando porém, nos cálculos, uma taxa de armadura maior que $0,4 \%$. A norma britânica BS 5400: Parte 5 recomenda a colocação de, pelo menos, 4 barras longitudinais.

Algumas normas também fazem recomendações com relação ao espaçamento dos estribos. Em pilares revestidos, a norma americana AISC-LRFD recomenda um espaçamento máximo entre estribos igual a $2 / 3$ da menor dimensão da seção mista e a norma britânica BS 5400: Parte 5, igual a $200 \mathrm{~mm}$.

A NBR 14323 apresenta as seguintes disposições construtivas a serem obedecidas para os pilares parcialmente preenchidos:

- O concreto entre as mesas do perfil de aço deve ser fixado por meio de estribos e/ou conectores de cisalhamento; 
- Os estribos podem ser soldados na alma ou penetrar a alma do perfil através de furos. Os conectores de cisalhamento, por sua vez, devem ser soldados na alma do perfil;

- O espaçamento dos estribos ou conectores de cisalhamento ao longo do comprimento do pilar não deve exceder $500 \mathrm{~mm}$.

Devem ainda ser respeitadas dimensões mínimas da seção transversal, de recobrimento mínimo de concreto e distâncias mínimas dos eixos das barras da armadura à face do concreto, de acordo com as especificações referentes a pilares mistos em situação de incêndio, as quais serão abordadas no capítulo seguinte.

\section{Espessura da parede do perfil tubular em pilares preenchidos}

Em pilares mistos preenchidos, é necessário limitar a espessura da parede do perfil tubular para evitar a ocorrência de flambagem local. As limitações de espessura indicadas pelo EUROCODE 4 e pela norma britânica BS 5400: Parte 5 são apresentadas nos itens 5.5.5 e 5.5.6, respectivamente. A norma brasileira que aborda este assunto é apresentada no item 5.5.2.

\subsection{COMPORTAMENTO ESTRUTURAL}

Diversos parâmetros influenciam o comportamento conjunto dos componentes aço e concreto e, consequentemente, o comportamento do pilar misto. Entre esses parâmetros, estão o efeito do confinamento do concreto, o efeito da fluência e da retração, a aderência, a forma da seção transversal, a esbeltez, a razão entre as áreas do perfil de aço e a área total da seção, entre outros. No entanto, alguns desses fatores são mais significativos do que outros na avaliação da resistência final do pilar. Várias pesquisas foram realizadas no sentido de avaliar a influência desses parâmetros, de modo que possam ser considerados no projeto de pilares mistos de maneira prática e eficiente.

\section{Efeito do confinamento}


O efeito do confinamento no comportamento de pilares mistos preenchidos é um assunto ainda pouco estudado, devido principalmente à dificuldade de se realizar investigações experimentais que avaliem não somente a sua ocorrência, mas também a magnitude desse efeito em pilares de diferentes seções transversais.

$\mathrm{O}$ efeito de confinamento ocorre quando, a partir de um certo nível de carregamento do pilar, a expansão lateral do concreto é maior que a do perfil de aço, desenvolvendo-se, assim, pressões radiais na interface aço-concreto, estando o concreto submetido a um estado triaxial de tensões. $O$ desenvolvimento dessas pressões radiais, combinadas com a força normal de compressão atuante, reduzem a resistência ao escoamento do perfil de aço, de acordo com o critério de von Mises. Por outro lado, ocorre um acréscimo de resistência à compressão do concreto quando comparado ao concreto não confinado. O resultado final desse efeito nos dois materiais é um ganho na capacidade do pilar misto.

O grau de acréscimo à capacidade do pilar devido ao confinamento depende de alguns fatores, tais como a espessura do perfil tubular, a esbeltez do pilar misto, a excentricidade da força normal, a resistência característica do concreto à compressão, a resistência ao escoamento do aço e a forma da seção transversal.

A magnitude do confinamento e seus efeitos benéficos são maiores em pilares curtos que em pilares esbeltos. Esses efeitos benéficos também são mais significativos em pilares que possuem menores excentricidades com relação à força normal.

Com respeito à forma da seção transversal, pode-se afirmar que o grau de confinamento em pilares mistos com perfis circulares é consideravelmente maior que em pilares mistos de seção retangular. As normas, considerando esse fato, desprezam o efeito do confinamento na capacidade de pilares mistos de seção retangular. Entretanto, vale relembrar que ainda existem dúvidas relacionadas com o grau de confinamento do concreto e sua influência na resistência do pilar misto, necessitando ser melhor estudada.

DE NARDIN (1999) realizou ensaios em pilares mistos de seções quadradas, circulares e retangulares, preenchidos com concreto de alta resistência. O objetivo desse trabalho constituiu-se na análise do comportamento de pilares mistos 
axialmente comprimidos, de modo a avaliar parâmetros como a influência da forma da seção transversal e da espessura do perfil tubular. Os ensaios mostraram que, embora o efeito de confinamento contribua de forma decisiva na melhoria do comportamento dos materiais, seus efeitos não são significativos no aumento da capacidade resistente da seção mista.

\section{Efeitos da retração e da fluência}

Após o endurecimento do concreto, aço e concreto passam a trabalhar de maneira conjunta, caracterizando o comportamento misto. A partir desse momento, os efeitos da fluência e da retração produzem deformações adicionais ao concreto, as quais serão transferidas gradualmente ao perfil de aço.

A fluência conduz a deformações por carregamentos constantes de longa duração. Os efeitos da retração em pilares mistos são menores quando comparados com pilares de concreto armado, pois existe a proteção do perfil de aço diante das intempéries, no caso de pilares prenchidos.

O acréscimo de deformações produzido pela fluência e pela retração do concreto pode induzir o escoamento ou a flambagem local do perfil tubular de aço em pilares preenchidos. TERREY et al. 1 apud UY \& DAS (1997) consideraram este comportamento em pilares mistos preenchidos de seções circulares, por meio de uma extensa investigação experimental, onde foram medidas as deformações devido à fluência e à retração e estudados seus efeitos na redistribuição de tensões entre aço e concreto.

GOMES (1994) ${ }^{\text {口 }}$ apud DE NARDIN (1999) estudou os efeitos da retração e da fluência sobre as tensões no concreto em pilares mistos tubulares axialmente comprimidos. Segundo as conclusões de seu estudo, os efeitos da retração do concreto sobre a resistência à compressão do pilar misto são pouco significativos. Outra conclusão do trabalho está relacionada com os efeitos da fluência em função

\footnotetext{
${ }^{1}$ TERREY, P.J.; BRADFORD, M.A.; GILBERT, R.I. (1994). Creep and shrinkage in concrete filled steel tubes. Proceedings of Sixth International Symposium on Tubular Structures, Tubular Structures VI, p.227-84.

${ }^{2}$ GOMES, N.S. (1994) Pilares mistos tubulares de aço e concreto. São Paulo. Tese (doutorado) Escola Politécnica da Universidade de São Paulo.
} 
da resistência do concreto: menores serão esses efeitos quanto maior for a resistência do concreto. Os efeitos da fluência podem ser minimizados, com o aumento da resistência do concreto de preenchimento e com a colocação de barras longitudinais de armadura.

\section{Conexão aço-concreto}

A transferência de esforços na interface dos dois materiais, aço e concreto, ocorre por aderência. Essa transmissão de esforços pode ser feita simplesmente por adesão e atrito, cuja força é proporcional à área da interface aço-concreto e ao esforço normal aplicado. A transmissão de esforços pode também realizar-se por conexão mecânica, utilizando-se conectores de cisalhamento.

Algumas pesquisas já realizadas tiveram por objetivo estudar os fatores que influenciam a aderência entre aço e concreto. Essas também procuraram investigar como é que a resistência do pilar misto é afetada pela aderência.

As normas consideram como hipótese básica para o dimensionamento de pilares mistos a perfeita ação conjunta entre os dois materiais, ou seja, a interação completa. Para a manutenção dessa hipótese, não deve haver deslizamento relativo excessivo entre os dois materiais. É por esse motivo que o EUROCODE 4, por exemplo, estabelece a tensão máxima de cisalhamento que pode ocorrer na interface aço-concreto, denominada tensão limite de aderência, sem que seja necessário o emprego de conectores de cisalhamento.

WIUM \& LEBET (1994), com base em resultados experimentais realizados em pilares mistos revestidos, investigaram a transmissão de esforços cisalhantes na superfície aço-concreto por meio da aderência por atrito. Consideraram no estudo alguns parâmetros que interferem nessa transmissão, tais como o recobrimento de concreto, a taxa de armadura longitudinal empregada, as dimensões do pilar de aço a ser revestido e a retração do concreto. Uma das mais importantes conclusões tiradas dessa investigação é o fato de a máxima tensão resistente de aderência ser dependente das dimensões do perfil de aço: quanto maior a largura do perfil, maior a fissuração do concreto e, consequentemente, menor a intensidade da força transferida por aderência. Outro resultado obtido desse trabalho foram as tensões últimas de 
aderência obtidas experimentalmente, as quais assumiram valores consideravelmente menores (aproximadamente 50\%) em relação a tensão limite fornecida pelo EUROCODE 4.

GOMES (1994) apud FIGUEIREDO (1998) realizou um estudo experimental em pilares mistos tubulares, composto por ensaios em 22 elementos, sendo 12 deles ensaiados após 28 dias de moldagem e 10 elementos novamente ensaiados após 8 anos de exposição ao ar livre. Nos primeiros 12 elementos, a aderência química foi quebrada após a execução do ensaio, devido ao deslocamento relativo entre os dois materiais. Nos elementos submetidos aos 8 anos de exposição, onde restava apenas a parcela de aderência mecânica, verificou-se um aumento médio de $16 \%$ da tensão última de aderência. Segundo o pesquisador, existem duas justificativas para esse acréscimo: a primeira é o envelhecimento do concreto, que oferece maior resistência ao deslizamento. A segunda é o surgimento de zonas de corrosão no perfil tubular, o que também dificulta o deslizamento relativo entre os materiais.

\section{Outros fatores:}

A resistência do concreto representa outro fator de influência na capacidade de pilares mistos e, com o advento das pesquisas em torno do concreto de alta resistência, muitos trabalhos têm sido realizados com o objetivo de avaliar a interferência da resistência do concreto. Segundo algumas dessas pesquisas, a utilização de concretos com resistência à compressão maiores aumenta, de fato, a capacidade do pilar misto, porém esse acréscimo é mais significativo em pilares curtos que em pilares esbeltos.

A flambagem local do perfil de aço em pilares preenchidos também pode afetar o comportamento da seção mista. As principais normas aplicáveis apresentam valores máximos de relação largura/espessura que podem ser adotados para os perfis tubulares de aço, sem que seja necessária a verificação da flambagem local.

UY (1998) destaca as diferenças na configuração da flambagem local para pilares de aço isolados e para pilares preenchidos de concreto, ambos com seções tubulares retangulares, ilustradas na figura 5.6. Em pilares de aço isolados, observase que as paredes do tubo podem deslocar-se para dentro do perfil, o que não é 
verificado em pilares mistos preenchidos, devido à presença do núcleo de concreto. Neste caso, o deslocamento das paredes do tubo somente se dá para fora do pilar.

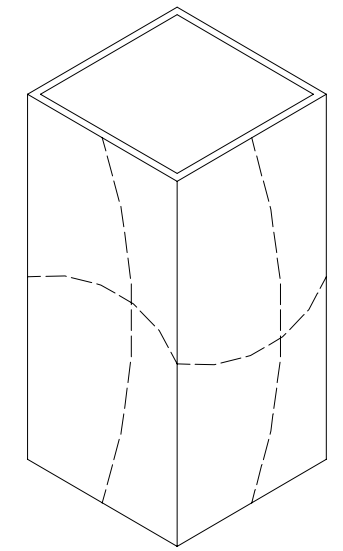

a) Perfil tubular de aço

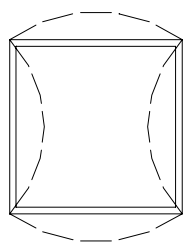

FIGURA 5.6: Flambagem local para pilares mistos constituidos por perfis tubulares retangulares - UY (1998)

\subsection{DIMENSIONAMENTO SEGUNDO AS PRINCIPAIS NORMAS}

As principais normas que tratam do dimensionamento de pilares mistos abordam o assunto sob diferentes ângulos, pois os procedimentos e considerações dos estudos experimentais muitas vezes variam de um país para outro. Algumas normas consideram os pilares mistos como pilares de aço com capacidade estrutural aumentada devido à presença benéfica do concreto. É o caso da norma americana AISC-LRFD (1994), da norma canadense CAN/CSA-S16.1 (1994) e da norma britânica BS 5400: Parte 5 (1979). Algumas normas, entretanto, consideram o pilar misto como um pilar de concreto com armadura especial, devido à presença do perfil de aço. Esta filosofia é adotada pelo ACI 318 (1992). Outras ainda consideram os pilares mistos como combinação dos dois raciocínios. É o caso do EUROCODE 4 (1992).

Neste item serão descritos os procedimentos de cálculo de algumas das principais normas que abordam o dimensionamento de pilares mistos. 


\subsubsection{NBR 8800 (1986)}

A norma brasileira de estruturas de aço é omissa em relação aos pilares mistos aço-concreto. Entretanto, pelo fato das principais normas adotarem as curvas de resistência à compressão de elementos de aço isolados para o dimensionamento de pilares mistos sujeitos à compressão, pode-se adaptar esse mesmo procedimento à NBR 8800 (1986), sem que isso deixe de parecer razoável. O mesmo raciocínio pode ser adotado no caso de pilares mistos submetidos à flexo-compressão, utilizando-se as expressões de interação momento-normal fornecidas pela norma.

\subsubsection{NBR 14323 (1999)}

Por outro lado, a norma brasileira NBR 14323 (1999): Dimensionamento de estruturas de aço de edifícios em situação de incêndio apresenta critérios para o dimensionamento de pilares mistos a temperatura ambiente, de acordo com o anexo B desta norma. Esses procedimentos são idênticos aos apresentados no método simplificado pelo EUROCODE 4 (1992), aplicável aos pilares mistos duplamente simétricos e de seção constante.

Segundo esta norma brasileira, as resistências de todos os materiais devem ser alcançadas sem que ocorra flambagem local dos elementos do perfil de aço. Para evitar a flambagem local, a norma estabelece valores máximos da relação largura/espessura, iguais aos recomendados pelo EUROCODE 4 (ver item 5.5.5).

As verificações relacionadas com a resistência ao cisalhamento na interface aço-concreto são as mesmas das apresentadas pela norma européia.

A resistência de cálculo à compressão axial $\left(N_{p l, R d}\right)$, admitindo-se plastificação total da seção, é determinada conforme as expressões (5.41) e (5.42), utilizando os coeficientes de resistência indicados pela norma brasileira:

$\phi_{a}$ é o coeficiente de resistência do aço, igual a 0,9 ;

$\phi_{S}$ é o coeficiente de resistência do aço da armadura, igual a 0,85 ;

$\phi_{c}$ é o coeficiente de resistência do concreto, igual a 0,7 . 
A resistência de cálculo à compressão $N_{R d}$ de pilares mistos é calculada como na expressão (5.51), resultando em:

$N_{R d}=\rho N_{p l, R d}$

onde

$\rho$ é o fator de redução associado à flambagem, fornecido pela NBR 8800, cujo valor é determinado em função da esbeltez relativa (ou reduzida), conforme a expressão (5.50), e da curva de resistência à compressão adequada, devendo-se tomar:

- curva "a" para perfis tubulares de aço preenchidos com concreto,

- curva "b" para perfis de aço tipo I, total ou parcialmente revestidos de concreto, com flambagem em torno do eixo de maior inércia;

- curva "c" para perfis de aço tipo I, total ou parcialmente revestidos de concreto, com flambagem em torno do eixo de menor inércia.

A verificação de pilares mistos submetidos à flexo-compressão é feita por meio da seguinte expressão de interação:

$$
\mu_{k} \frac{N_{S d}-N_{n}}{N_{R d}-N_{n}}+\frac{C_{m x} M_{x, S d}}{\left(1-\frac{N_{S d}-N_{n}}{N_{e x}}\right) 0,9 M_{x, p l, R d}}+\frac{C_{m y} M_{y, S d}}{\left(1-\frac{N_{S d}-N_{n}}{N_{e y}}\right) 0,9 M_{y, p l, R d}} \leq \mu_{d}
$$

onde

$\mu_{k}=\frac{N_{p l, R d}-N_{R d}}{N_{p l, R d}-N_{c}} \leq 1,0 \quad$ (para pilar sem flambagem, $\mu_{k}=0$ )

$\mu_{d}=\frac{N_{p l, R d}-N_{S d}}{N_{p l, R d}-N_{c}} \leq 1,0$

$N_{n}=N_{R d} \frac{(1+r)}{4} \leq N_{S d}$

$r=\frac{M_{1}}{M_{2}}$ 
$N_{c}=\alpha \phi_{c} f_{c k} A_{c}$

$A_{c}$ é a área da seção transversal de concreto;

$\alpha=1,0$ para pilares preenchidos e igual a 0,85 para pilares revestidos;

$M_{1}$ e $M_{2}$ são o menor e o maior momento de extremidade do pilar. A relação $M_{1} / M_{2}$ é positiva quando esses momentos provocarem curvatura reversa e negativa em caso de curvatura simples. Quando o momento, em alguma seção intermediária, for superior, em valor absoluto, a $M_{1}$ e $M_{2}$, o valor de $r$ deve ser tomado igual a 1,0 . Também, no caso de balanços, $r$ deve ser tomado igual a 1,0.

$N_{S d}$ é a força normal de cálculo;

$M_{x, S d}$ é o momento fletor de cálculo em torno do eixo x, na seção considerada;

$M_{y, S d}$ é o momento fletor de cálculo em torno do eixo y, na seção considerada;

$N_{p l, R d}$ é a resistência de cálculo à compressão axial, admitindo-se plastificação total da seção, conforme as expressões (5.41) ou (5.42);

$M_{x, p l, R d}$ é a resistência de cálculo ao momento fletor em torno do eixo x da seção mista, considerando-se a plastificação total da seção, calculada conforme a expressão (5.3);

$M_{y, p l, R d}$ é a resistência de cálculo ao momento fletor em torno do eixo y da seção mista, considerando-se a plastificação total da seção, calculada conforme a expressão (5.3);

$N_{e x}$ é a normal de flambagem elástica por flexão no eixo x;

$N_{e y}$ é a normal de flambagem elástica por flexão no eixo y;

$C_{m x}$ e $C_{m y}$ são fatores de equivalência de carregamento, determinados no item 5.6 da NBR 8800:

- Para barras de estruturas indeslocáveis, não sujeitas a cargas transversais entre apoios:

$$
C_{m}=0,6-0,4 \frac{M_{1}}{M_{2}} \geq 0,4
$$

- Para barras de estruturas indeslocáveis, sujeitas a cargas transversais entre apoios, o valor de $C_{m}$ pode ser determinado por análise ou ser tomado igual a 0,85 no caso de barras com ambas as extremidades engastadas e 1,0 nos demais casos. 
- Para barras de estruturas deslocáveis, $C_{m}$ pode ser tomado igual a 0,85 , caso não se faça análise de segunda ordem. Caso esta análise seja feita, o valor de $C_{m}$ será determinado como se a estrutura fosse indeslocável.

A expressão (5.2) deriva da curva de interação momento-normal apresentada pelo EUROCODE 4 (figura 5.12). No entanto, essa expressão conduz a uma curva mais simplificada que a curva da norma européia, sendo formada apenas por dois segmentos de retas: trecho AC e trecho CB (ver figura 5.12), desconsiderando-se, portanto, valores de momento resistente maiores que o momento de plastificação $M_{p l, R d}$.

A força $N_{n}$ é análoga ao adimensional $\chi_{n}$ do EUROCODE 4 (ver definição pela expressão 5.55), o qual leva em conta a diminuição do momento de segunda ordem, para uma dada força normal, à medida que a relação $M_{1} / M_{2}$ assume valores menores que 1,0 .

Os momentos resistentes de cálculo $M_{x, p l, R d}$ e $M_{y, p l, R d}$ da expressão (5.2) podem ser calculados pela seguinte expressão genérica, dada pela norma:

$M_{p l, R d}=f_{y d}\left(Z_{p a}-Z_{p a n}\right)+0,5 f_{c d}\left(Z_{p c}-Z_{p c n}\right)+f_{s d}\left(Z_{p s}-Z_{p s n}\right)$

onde

$f_{y d}=\phi_{a} f_{y}$;

$f_{s d}=\phi_{s} f_{s y}$

$f_{c d}=\phi_{c} f_{c k}$

$\alpha=1,0$ para pilares preenchidos e igual a 0,85 para os demais;

$Z_{p a}$ é o módulo de resistência plástico da seção do perfil de aço;

$Z_{p s}$ é o módulo de resistência plástico da seção da armadura;

$Z_{p c}$ é o módulo de resistência plástico da seção de concreto, não fissurado;

Tanto para pilares preenchidos quanto revestidos, tem-se:

$$
Z_{p s}=\sum_{i=1}^{n} A_{s i} e_{i}
$$


$Z_{p s n}=\sum_{i=1}^{n} A_{s n i} e_{y i}$

onde

$e_{i}$ são as distâncias dos eixos das barras da armadura de área $A_{s i}$ aos eixos de simetria da seção;

$e_{y i}$ são as distâncias dos eixos das barras da armadura ao eixo x;

$A_{s n i}$ são as áreas das barras da armadura na região $2 h_{n}$;

$h_{n}$ é a distância do eixo de flexão à linha neutra. A distância $2 h_{n}$ representa a região compreendida entre duas linhas neutras simétricas (ver figuras 5.7, 5.8 e 5.9);

$Z_{p a n}$ e $Z_{p c n}$ são os módulos de resistência plásticos do perfil de aço e da seção de concreto, respectivamente, na região $2 h_{n}$.

Uma vez determinada a posição da linha neutra na seção mista, pode-se calcular os módulos de resistência plásticos restantes nos dois tipos de pilares mistos.

Pilares mistos revestidos com perfil de aço tipo I:
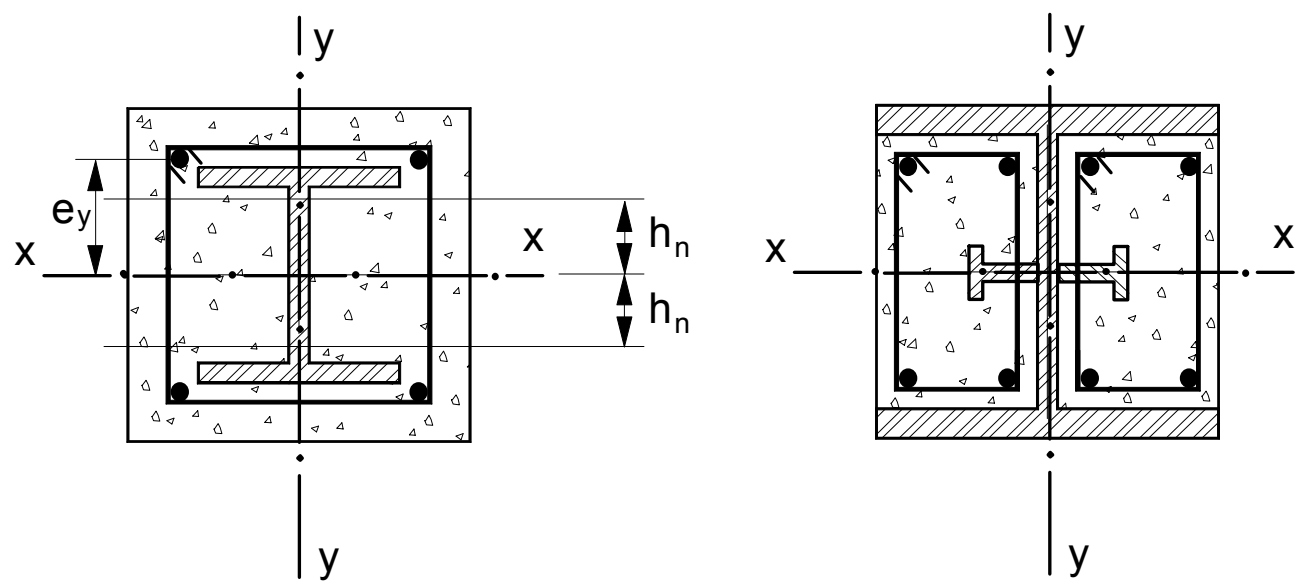

FIGURA 5.7: Perfil "I" revestido com concreto e fletido em torno do eixo de maior inércia

Nas expressões que se seguem, $h$ é a altura do perfil de aço e $h_{c}$ é a altura da seção de concreto, no caso de pilares totalmente revestidos, ou igual a $h$, no caso de pilares parcialmente revestidos, conforme a figura 5.1. 
a) Eixo de maior inércia:

$Z_{p c}=\frac{b_{c} h_{c}^{2}}{4}-Z_{p a}-Z_{p s}$

a.1) Linha neutra plástica na alma do perfil de aço $\left(h_{n} \leq h / 2-t_{f}\right)$ :

$h_{n}=\frac{A_{c} f_{c d}-A_{s n}\left(2 f_{s d}-f_{c d}\right)}{2 b_{c} f_{c d}+2 t_{w}\left(2 f_{y d}-f_{c d}\right)}$

$Z_{p a n}=t_{w} h_{n}^{2}$

$Z_{p s n}=\sum_{i=1}^{n} A_{s n i} e_{y i}$

$Z_{p c n}=b_{c} h_{n}^{2}-Z_{p a n}-Z_{p s n}$

a.2) Linha neutra plástica na mesa do perfil de aço $\left(h / 2-t_{f} \leq h_{n} \leq h / 2\right)$ :

$h_{n}=\frac{A_{c} f_{c d}-A_{s n}\left(2 f_{s d}-f_{c d}\right)+\left(b_{f}-t_{w}\right)\left(h-2 t_{f}\right)\left(2 f_{y d}-f_{c d}\right)}{2 b_{c} f_{c d}+2 b_{f}\left(2 f_{y d}-f_{c d}\right)}$

$Z_{\text {pan }}=b_{c} h_{n}^{2}-\frac{\left(b_{f}-t_{w}\right)\left(h-2 t_{f}\right)^{2}}{4}$

$Z_{p c n}=b_{c} h_{n}^{2}-Z_{p a n}-Z_{p s n}$

a.3) Linha neutra plástica fora do perfil de aço $\left(h / 2 \leq h_{n} \leq h_{c} / 2\right)$ :

$h_{n}=\frac{A_{c} f_{c d}-A_{s n}\left(2 f_{s d}-f_{c d}\right)-A_{a}\left(2 f_{y d}-f_{c d}\right)}{2 b_{c} f_{c d}}$ 
$Z_{p a n}=Z_{p a}$

$Z_{p c n}=b_{c} h_{n}^{2}-Z_{p a n}-Z_{p s n}$

b) Eixo de menor inércia:
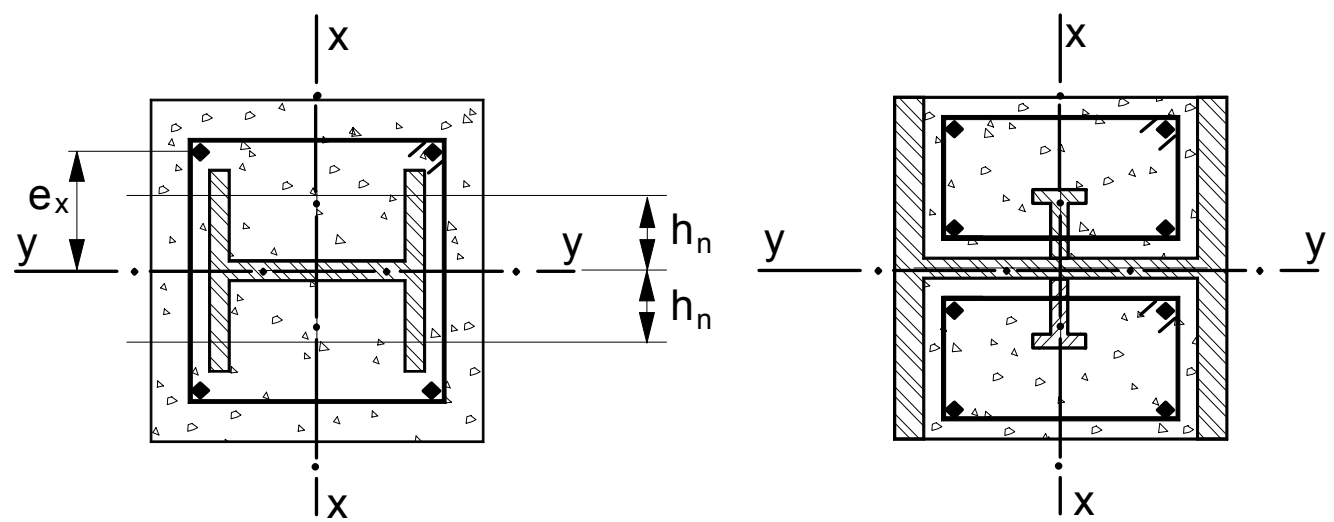

FIGURA 5.8: Seção I revestida com concreto fletida em torno do eixo de menor inércia

$Z_{p c}=\frac{h_{c} b_{c}^{2}}{4}-Z_{p a}-Z_{p s}$

b.1) Linha neutra plástica na alma do perfil de aço $\left(h_{n}<t_{w} / 2\right)$ :

$h_{n}=\frac{A_{c} f_{c d}-A_{s n}\left(2 f_{s d}-f_{c d}\right)}{2 h_{c} f_{c d}+2 h\left(2 f_{y d}-f_{c d}\right)}$

$Z_{\text {pan }}=h h_{n}^{2}$

$Z_{p c n}=h_{c} h_{n}^{2}-Z_{p a n}-Z_{p s n}$

b.2) Linha neutra plástica na mesa do perfil de aço $\left(t_{w} / 2<h_{n}<b_{f} / 2\right)$ :

$h_{n}=\frac{A_{c} f_{c d}-A_{s n}\left(2 f_{s d}-f_{c d}\right)+t_{w}\left(2 t_{f}-h\right)\left(2 f_{s d}-f_{c d}\right)}{2 h_{c} f_{c d}+4 t_{f}\left(2 f_{y d}-f_{c d}\right)}$ 


$$
\begin{aligned}
& Z_{p a n}=2 t_{f} h_{n}^{2}+\frac{\left(h-2 t_{f}\right) t_{w}^{2}}{4} \\
& Z_{p c n}=h_{c} h_{n}^{2}-Z_{p a n}-Z_{p s n}
\end{aligned}
$$

b.3) Linha neutra fora do perfil de aço $\left(b_{f} / 2 \leq h_{n} \leq b_{c} / 2\right)$

$$
\begin{aligned}
& h_{n}=\frac{A_{c} f_{c d}-A_{s n}\left(2 f_{s d}-f_{c d}\right)-A_{a}\left(2 f_{y d}-f_{c d}\right)}{2 h_{c} f_{c d}} \\
& Z_{p a n}=Z_{p a} \\
& Z_{p c n}=h_{c} h_{n}^{2}-Z_{p a n}-Z_{p s n}
\end{aligned}
$$

Pilares mistos preenchidos de seções retangulares ou circulares:

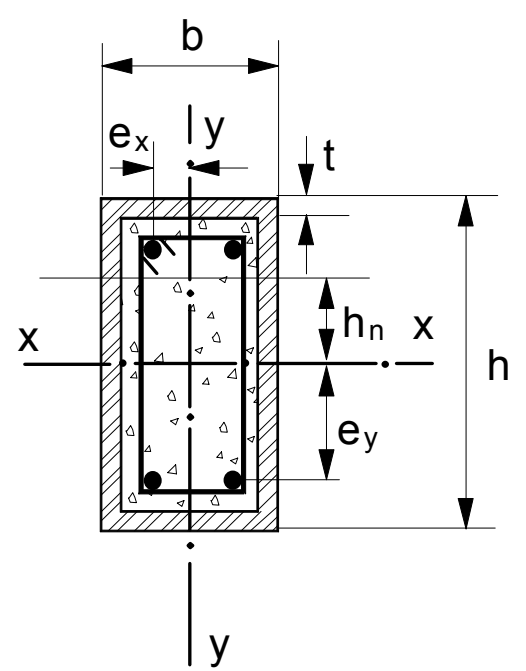

FIGURA 5.9: Seção tubular retangular

a.1) Eixo de maior inércia:

$$
\begin{aligned}
& Z_{p c}=\frac{(b-2 t)(h-2 t)^{2}}{4}-Z_{p s} \\
& h_{n}=\frac{A_{c} f_{c d}-A_{s n}\left(2 f_{s d}-f_{c d}\right)}{2 b f_{c d}+4 t\left(2 f_{y d}-f_{c d}\right)} \\
& Z_{p c n}=(b-2 t) h_{n}^{2}-Z_{p s n}
\end{aligned}
$$


$Z_{p a n}=b h_{n}^{2}-Z_{p c n}-Z_{p s n}$

a.2) Eixo de menor inércia:

Neste caso, devem ser utilizadas as expressões relativas ao eixo de maior inércia, permutando-se entre si as dimensões $h$ e $b$, bem como os índices subscritos x e y.

b) Seção tubular circular:

Neste caso, podem ser utilizadas as expressões relativas às seções tubulares retangulares, considerando $h=b=d$ e $r=d / 2-t$.

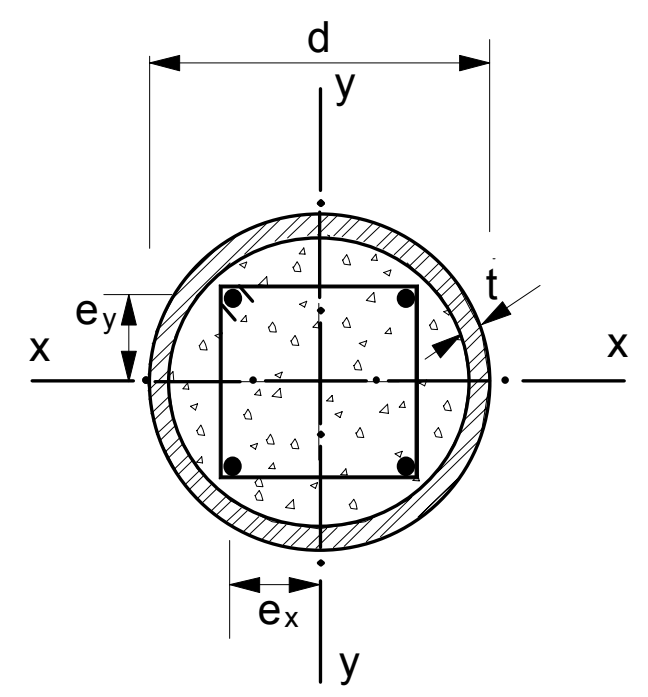

FIGURA 5.10: Seção tubular circular

\subsubsection{AISC-LRFD (1994)}

A norma americana apresenta a formulação do cálculo de pilares mistos com base nos procedimentos adotados para o cálculo de pilares de aço, fazendo modificações em alguns parâmetros, tais como o módulo de elasticidade e a esbeltez, a fim de considerar a presença benéfica do concreto. Leva em consideração o efeito de confinamento em pilares preenchidos, sugerindo algumas correções aplicadas à resistência ao escoamento do aço e à resistência do concreto nestes casos. 
Com relação à flexo-compressão de pilares mistos, esta norma adota as mesmas expressões de interação empregadas na verificação de pilares de aço isolados.

\section{a) Parâmetros de cálculo modificados:}

O módulo de elasticidade $E_{m}$ e a resistência ao escoamento $f_{m y}$ são os parâmetros a serem modificados pela presença do concreto, calculados de acordo com as seguintes expressões:

$$
\begin{aligned}
& E_{m}=E+c_{3} E_{c} \frac{A_{c}}{A_{a}} \\
& f_{m y}=f_{y}+c_{1} f_{s y} \frac{A_{s}}{A_{a}}+c_{2} f_{c k} \frac{A_{c}}{A_{a}}
\end{aligned}
$$

onde

$E$ é o módulo de elasticidade do aço;

$E_{c}$ é o módulo de elasticidade do concreto, calculado por $E_{c}=42 \gamma_{c}{\sqrt[1]{f_{c k}}}$, com $E_{c}$

e $f_{c k}$ em MPa e $\gamma_{c}$ (peso específico do concreto) em $\mathrm{kN} / \mathrm{m}^{3}$;

$A_{c}$ é a área da seção transversal de concreto;

$A_{s}$ é a área da seção transversal da armadura longitudinal;

$A_{a}$ é a área da seção transversal do perfil de aço;

$f_{y}$ é a resistência ao escoamento do aço do perfil;

$f_{s y}$ é a resistência ao escoamento do aço da armadura;

$f_{c k}$ é a resistência característica do concreto à compressão;

$c_{1}, c_{2}$ e $c_{3}$ são coeficientes que dependem do tipo de pilar. Para pilares preenchidos, $c_{1}=1,0 ; c_{2}=0,85 ; c_{3}=0,40$. Para pilares revestidos, $c_{1}=0,7 ; c_{2}=0,6 ; c_{3}=0,2$.

A comparação entre os valores desses coeficientes para os dois tipos de pilares mostra que a norma americana considera o efeito do confinamento em pilares mistos preenchidos. 
b) Índice de esbeltez reduzido $\lambda_{m}$

$$
\lambda_{m}=\frac{1}{\pi} \frac{k L}{r_{m}} \sqrt{\frac{f_{m y}}{E_{m}}}
$$

onde

$k L$ é o comprimento efetivo de flambagem do pilar misto;

$r_{m}$ é o raio de giração modificado, podendo ser adotado igual ao raio de giração do perfil de aço, porém menor que $0,3 b$ no caso de pilares revestidos, sendo $b$ a dimensão da seção mista na direção perpendicular ao eixo de flambagem;

$E_{m}, f_{m y}$ são o módulo de elasticidade e resistência ao escoamento modificados, conforme as expressões (5.31) e (5.32).

Uma vez determinado o índice de esbeltez reduzido, pode-se obter a resistência à compressão da seção mista por um procedimento idêntico ao adotado para os pilares de aço isolados.

c) Resistência à compressão $\phi_{c} N_{n}$ :

$\phi_{c} N_{n}=0,85 A_{a} f_{c r}$

onde

$f_{c r}$ é a tensão crítica de flambagem global, determinada por:

$f_{c r}=\left(0,658^{\lambda_{m}^{2}}\right) f_{y} \quad$ para $\lambda_{m}<1,5$

$\mathrm{ou}$

$f_{c r}=\left(\frac{0,877}{\lambda_{m}^{2}}\right) f_{y} \quad$ para $\lambda \geq 1,5$

d) Verificação de elementos flexo-comprimidos: 
A verificação de elementos submetidos à flexo-compressão é análoga à dos pilares de aço isolados. As seguintes expressões de interação momento-normal devem ser utilizadas, empregando-se os parâmetros modificados devido à presença do concreto:

$$
\begin{aligned}
& \frac{N_{S d}}{\phi_{c} N_{n}}+\frac{8}{9}\left(\frac{M_{x, S d}}{\phi_{b} M_{n x}}+\frac{M_{y, S d}}{\phi_{c} M_{n y}}\right) \leq 1,0 \quad \text { para } \quad \frac{N_{S d}}{\phi_{c} N_{n}} \geq 0,2 \\
& \frac{N_{S d}}{2 \phi_{c} N_{n}}+\left(\frac{M_{x, S d}}{\phi_{b} M_{n x}}+\frac{M_{y, S d}}{\phi_{c} M_{n y}}\right) \leq 1,0 \quad \text { para } \quad \frac{N_{S d}}{\phi_{c} N_{n}}<0,2
\end{aligned}
$$

onde

$\phi_{c} N_{n}$ é a resistência à compressão do pilar misto, conforme a expressão (5.34);

$\phi_{b} M_{n x}$ e $\phi_{b} M_{n y}$ são a resistência de cálculo ao momento fletor da seção mista em torno dos eixos x e y, respectivamente, $\operatorname{com} \phi_{b}=0,9$. Quando a parcela da força normal na expressão de interação for menor que 0,3 , o momento nominal $M_{n}$ deve ser determinado por meio da interpolação linear entre o momento nominal obtido a partir de uma distribuição de tensões na seção mista com $N_{S d} / \phi_{c} N_{n}=0,3$ e o momento nominal a partir da distribuição de tensões com $N_{S d}=0$;

$M_{x, S d}$ e $M_{y, S d}$ são o momento fletor de cálculo em torno dos eixos x e $\mathrm{y}$, respectivamente, já incluídos os efeitos de segunda ordem.

A norma americana apresenta um método simplificado para a consideração dos efeitos de segunda ordem, admitindo que o momento fletor de segunda ordem seja a soma de duas parcelas: uma de caráter local, associada com o efeito de amplificação de momentos na barra, devido às ações gravitacionais, e outra de caráter global, associada com a amplificação de momentos na estrutura como um todo, devido às ações laterais.

\subsubsection{CAN/CSA-S16.1 (1994)}


Os pilares mistos abordados pela norma canadense são os pilares preenchidos. Esta norma admite o pilar misto como um pilar de aço com resistência aumentada pela presença do concreto, não considerando, entretanto, o efeito de confinamento e nem a contribuição da armadura longitudinal.

Tanto a resistência à compressão e quanto a resistência ao momento fletor do pilar misto são apresentadas como a soma de duas parcelas: da resistência do perfil de aço isolado e da parcela resistente da área de concreto.

A flexo-compressão é tratada de maneira análoga à apresentada para os pilares de aço.

\section{- Resistência à compressão: $N_{R d}$}

$N_{R d}=\alpha\left(N_{R d}\right)_{a}+\beta\left(N_{R d}\right)_{c}$

onde

$\left(N_{R d}\right)_{a}$ é a resistência à compressão do perfil de aço, expressa por:

$\left(N_{R d}\right)_{a}=\phi_{a} A_{a} f_{y}\left(\frac{1}{1+\bar{\lambda}^{-2 n}}\right)^{\frac{1}{n}}$

sendo

$\phi_{a}=0,9 ;$

$\bar{\lambda}=\frac{1}{\pi} \frac{K L}{r} \sqrt{\frac{f_{y}}{E}} ;$

$n=1,34$ (seção tubular, conforme descrito pela norma);

$r$ é o raio de giração da seção transversal do perfil de aço, em relação ao eixo de flambagem;

$K L$ é o comprimento efetivo de flambagem;

$\left(N_{R d}\right)_{c}$ é a contribuição de resistência à compressão da área de concreto, dada por:

$\left(N_{R d}\right)_{c}=0,85 \phi_{c} f_{c k} A_{c} \lambda_{c}^{-2}\left(\sqrt{1+0,25 \lambda_{c}^{-4}}-0,5 \lambda_{c}^{-2}\right)$ 
sendo

$\phi_{c}=0,6$

$\lambda_{c}=\frac{1}{\pi} \frac{K L}{r_{c}} \sqrt{\frac{f_{c k}}{E_{c}}}$

$r_{c}$ é o raio de giração da seção transversal de concreto, em relação ao eixo de flambagem;

$E_{c}$ é o módulo de elasticidade do concreto, calculado, neste caso, considerando os efeitos da deformação lenta, por:

$E_{c}=\left(1+\frac{S}{T}\right) 2500 \sqrt{f_{c k}}$, onde $S / T$ representa a relação entre o carregamento de curta duração e o carregamento total no pilar.

$\alpha=\beta=1,0$ para todos os pilares de seção retangular e os de seção circular cuja relação altura do pilar /diâmetro $(L / d)$ seja maior ou igual a 25 . Quando $L / d<25$, tem-se:

$\alpha=\frac{1}{\sqrt{1+\rho+\rho^{2}}}$ e $\beta=1+\left(25 \rho^{2} \alpha \frac{t}{d}\right)\left(\frac{f_{y}}{0,85 f_{c k}}\right)$

onde $\rho=0,02\left(25-\frac{L}{d}\right)$

- Resistência ao momento fletor da seção mista: $M_{R d}$

A resistência ao momento fletor pode ser determinada considerando-se a plastificação total da seção e a interação completa entre aço e concreto, desprezandose a zona de concreto tracionado e a contribuição da armadura longitudinal. Os coeficientes de resistência dos materiais são: $\phi_{a}=0,9$ para o aço e $\phi_{c}=0,6$ para o concreto.

- Verificação de elementos flexo-comprimidos: 
A norma canadense apresenta a expressão de interação momento-normal para pilares mistos submetidos à flexo-compressão reta, podendo, evidentemente, ser estendida para o caso de flexo-compressão oblíqua:

$\frac{N_{S d}}{N_{R d}}+\frac{\omega_{1} M_{S d}}{M_{R d}\left(1-\frac{N_{S d}}{N_{e}}\right)}$

onde

$N_{S d}$ é a força normal de cálculo;

$N_{R d}$ é a resistência à compressão da seção mista, conforme a expressão (5.37);

$\omega_{1}$ é o fator de equivalência de carregamento, equivalente ao coeficiente $C_{m}$ da norma brasileira.

$M_{R d}$ é o momento resistente de cálculo da seção mista;

$N_{e}$ é a força normal de flambagem elástica da seção mista. A norma canadense não apresenta formulação para a obtenção de $N_{e}$. Neste caso, existem duas alternativas: utilizar os parâmetros modificados da norma americana AISC-LRFD (1994) ou a rigidez à flexão equivalente apresentada pelo EUROCODE 4 (1994), conforme a expressão (5.46). Os resultados dessas duas expressões, entretanto, podem apresentar diferenças significativas.

\subsubsection{EUROCODE 4: PARTE 1.1 (1992)}

O EUROCODE 4 apresenta dois procedimentos de cálculo que permitem avaliar a resistência de pilares mistos, a saber:

- Método Geral: Aplicável a seções transversais tanto simétricas quanto assimétricas, podendo ser variáveis ao longo da altura. Leva em consideração o efeito de segunda ordem, incluindo as imperfeições geométricas do pilar. Tornase necessária a utilização de métodos numéricos para a aplicação deste método. 
- Método Simplificado: Aplicável apenas a seções transversais duplamente simétricas e constantes ao longo da altura. Permite que a verificação do pilar misto seja feita sem a necessidade de se recorrer a métodos computacionais. Este método toma como base as curvas de resistência à compressão do EUROCODE 3 (1992) para perfis de aço.

Limitações da aplicação do método simplificado:

O campo de aplicação do método simplificado é limitado segundo algumas condições:

- A seção do pilar misto deve ser duplamente simétrica e constante ao longo da altura do mesmo;

- O parâmetro de contribuição do aço $\delta$, apresentado na expressão (5.48), deve estar compreendido entre 0,2 e 0,9 ;

- $\quad$ O índice de esbeltez reduzido, conforme a expressão (5.50), não deve ser superior a 2,0 ;

- A área da seção transversal da armadura longitudinal a ser considerada nos cálculos não deve ser superior a $4 \%$ da área de concreto;

- Os recobrimentos a serem utilizados nos cálculos, para pilares revestidos, devem estar compreendidos entre os seguintes valores:

$$
\begin{aligned}
& 40 \mathrm{~mm} \leq c_{x} \leq 0,4 b_{f} \\
& 40 \mathrm{~mm} \leq c_{y} \leq 0,3 d
\end{aligned}
$$

onde

$c_{x}$ e $c_{y}$ são os recobrimento nas direções x e y, respectivamente, conforme a figura 5.1;

$b_{f}$ é a largura da mesa do perfil de aço;

$d$ é a altura do perfil de aço. 
$\mathrm{O}$ anexo D do EUROCODE 4 apresenta um método simplificado para o dimensionamento de pilares mistos com seção transversal monossimétrica.

\section{Hipóteses de Cálculo:}

Os dois métodos de cálculo apresentados pelo EUROCODE 4 baseiam-se nas seguintes hipóteses:

- Interação completa entre o concreto e o perfil de aço até que se atinja a ruína;

- Imperfeições geométricas compatíveis com as adotadas na determinação da resistência de pilares de aço isolados;

- Utilização adequada da curva tensão x deformação para os três tipos de material (aço do perfil, aço da armadura e o concreto) no regime não-linear;

- Permanência de seções planas após a solicitação.

\section{Flambagem local:}

A flambagem local dos elementos de aço deve ser considerada na resistência do pilar misto, podendo ser evitada com a adoção das seguintes relações máximas largura/espessura:

- Pilares mistos preenchidos: Tubos retangulares: $\frac{h}{t} \leq 52 \sqrt{\frac{235}{f_{y}}}$

- Pilares mistos preenchidos: Tubos circulares: $\frac{d}{t} \leq 90\left(\sqrt{\frac{235}{f_{y}}}\right)^{2}$

- Pilares mistos parcialmente preenchidos: $\frac{b_{f}}{t_{f}} \leq 44 \sqrt{\frac{235}{f_{y}}}$

onde

$h$ é a largura da parede do tubo retangular;

$d$ é o diâmetro externo do tubo circular; 
$b_{f}$ é a largura da mesa;

$t_{f}$ é a espessura da mesa;

$f_{y}$ em MPa.

Quando as relações largura/espessura superam esses valores máximos, os efeitos da flambagem local devem ser avaliados através de um método apropriado, confirmado experimentalmente.

Não é necessária a verificação da flambagem local em pilares totalmente revestidos.

\section{Tensão Limite de Aderência}

As tensões de cisalhamento entre o aço e o concreto não devem superar as seguintes tensões limites de aderência:

- Pilares mistos preenchidos: 0,4 $\mathrm{MPa}$;

- Pilares mistos revestidos: 0,6 MPa;

- Pilares mistos parcialmente revestidos: 0,2 MPa.

Se a tensão atuante for menor que a tensão limite de aderência, então pode-se considerar a interação completa entre os dois materiais, visto que não existe escorregamento relativo significativo, não havendo, neste caso, necessidade do uso de conectores.

Segundo JOHNSON (1994), não existe um procedimento bem estabelecido para se determinar a tensão de cisalhamento na interface aço/concreto. No entanto, é usual utilizar um valor médio dessa tensão $\left(\tau_{S d}\right)$, calculado pela expressão:

$$
\tau_{S d}=\frac{N_{S, c}}{u_{a} L_{v}}
$$

onde 
$N_{S, c}$ é a força cortante na interface aço/concreto, admitida como parcela da força normal solicitante de cálculo $N_{S d}$, e determinada por:

$$
N_{S, c}=N_{S d}\left(1-\frac{A_{a}}{A_{t r}}\right)
$$

$A_{a}$ é a área da seção transversal do perfil de aço;

$A_{t r}$ é a área da seção transversal homogeneizada do pilar misto;

$u_{a}$ é o perímetro do perfil de aço;

$L_{v}$ é o comprimento de transferência do esforço cortante por aderência.

Esta norma recomenda que não se deve considerar um comprimento de transferência da força cortante longitudinal maior que o dobro da menor dimensão da seção transversal do perfil.

Algumas simulações feitas em pilares revestidos, utilizando as expressões (5.39) e (5.40), propostas por JOHNSON (1994), mostraram que a tensão de cisalhamento na interface aço-concreto assume valores significativamente maiores que a tensão limite de aderência fornecida pela norma. A solução para este inconveniente recai na utilização de conectores.

Em pilares mistos revestidos, quando houver necessidade de se utilizar conectores de cisalhamento (tipo pino com cabeça) e estes forem fixados à alma do perfil de aço, pode-se considerar um aumento de resistência ao cisalhamento decorrente de um certo grau de confinamento do concreto, pois a expansão lateral do concreto é impedida entre alma e as mesas adjacentes do perfil de aço. Essa resistência adicional pode ser tomada igual a $0,5 \mu q_{R d}$ para cada fila de conectores, independente do número de conectores por fila, sendo $\mu$ igual a 0,5 e $q_{R d}$ igual à resistência individual de cálculo de um conector. Estes valores somente devem ser utilizados se a distância livre entre mesas atender aos seguintes valores:

- $300 \mathrm{~mm}$ quando houver um conector por fila;

- 400 quando houver dois conectores por fila;

- 600 quando houver três ou mais conectores por fila. 
Resumindo, o acréscimo de resistência é de $25 \%$ no caso de 1 conector por fila, de $12,5 \%$ para dois conectores e de $8,3 \%$ para três conectores por fila.

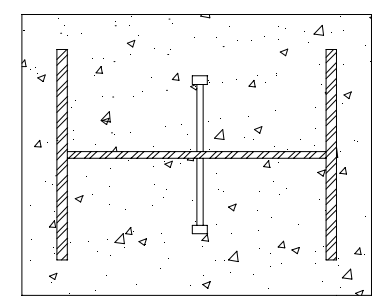

Acréscimo de resistência ao cisalhamento
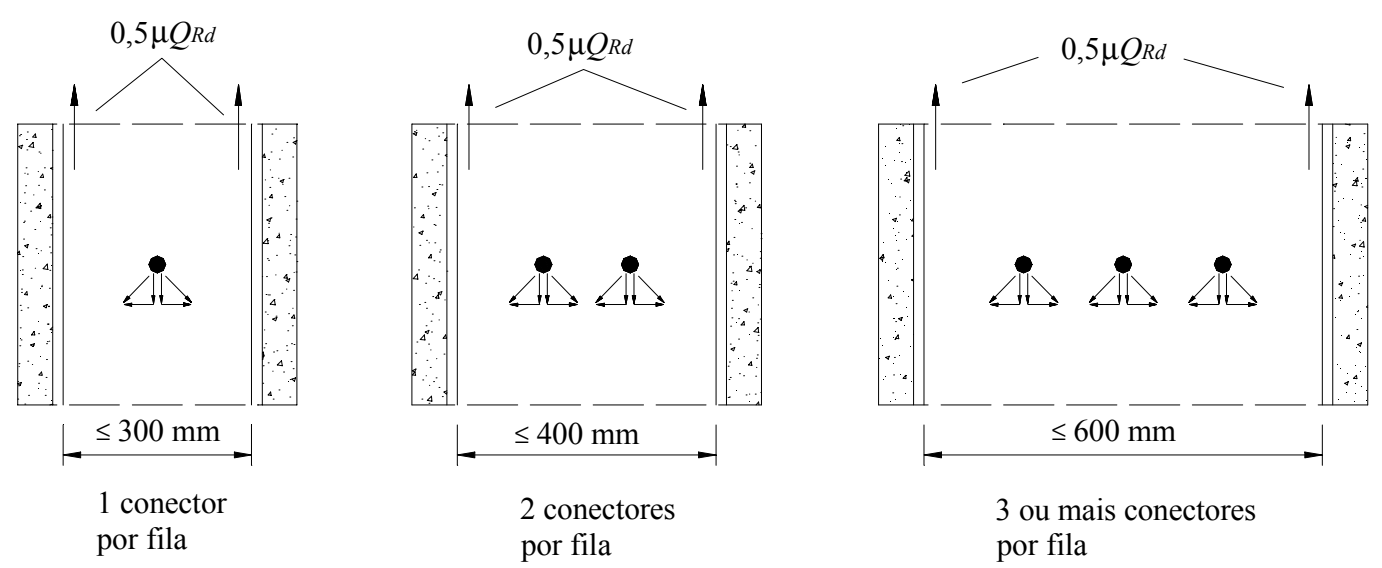

Distância livre máxima entre mesas

FIGURA 5.11: Conectores fixados à alma em pilares mistos revestidos

FORMULAÇÃO PARA O DIMENSIONAMENTO DE PILARES MISTOS

Para a determinação da resistência à compressão do pilar misto, inicialmente calcula-se a resistência à compressão da seção, admitindo-se plastificação total, sem considerar os efeitos de flambagem global. Este efeito é considerado em seguida, recorrendo-se às curvas de resistência à compressão dos pilares de aço, cujos parâmetros também são modificados pela presença de dois materiais.

a) Resistência à compressão, admitindo-se plastificação total da seção - $N_{p l, R d}$

a.1) Pilares revestidos e pilares retangulares preenchidos 


$$
N_{p l, R d}=\frac{A_{a} f_{y}}{\gamma_{a}}+\frac{A_{c} 0,85 f_{c k}}{\gamma_{c}}+\frac{A_{s} f_{s y}}{\gamma_{s}}
$$

onde

$A_{a}$ é a área da seção transversal do perfil de aço;

$A_{c}$ é a área da seção transversal de concreto;

$A_{s}$ é a área da seção transversal da armadura;

$f_{y}$ é a resistência ao escoamento do aço do perfil;

$f_{c k}$ é a resistência característica do concreto à compressão;

$f_{s y}$ é a resistência ao escoamento do aço da armadura;

$\gamma_{a}, \gamma_{c}, \gamma_{s}$ são o coeficiente de resistência do aço do perfil, do concreto e do aço da armadura, respectivamente. $\left(\gamma_{a}=1,10, \gamma_{c}=1,50, \gamma_{s}=1,15\right)$

\section{a.2) Pilares circulares preenchidos}

A resistência à compressão é determinada por:

$$
N_{p l, R d}=\frac{A_{a} \eta_{2} f_{y}}{\gamma_{a}}+\frac{A_{c} f_{c k}}{\gamma_{c}}\left[1+\eta_{1}\left(\frac{t}{d}\right)\left(\frac{f_{y}}{f_{c k}}\right)\right]+\frac{A_{s} f_{s y}}{\gamma_{s}}
$$

onde

$t$ é a espessura da parede do tubo;

$d$ é o diâmetro externo do tubo;

$\eta_{1}$ e $\eta_{2}$ são coeficientes que consideram o acréscimo de resistência devido ao efeito de confinamento do concreto.

Quando o índice de esbeltez reduzido $\bar{\lambda}$ (ver expressão 5.50) for maior que 0,5 e a excentricidade $e$ superar o valor de $d / 10$, o efeito de confinamento não é considerado.

$\eta_{1}$ e $\eta_{2}$ assumem os seguintes valores: 
- $\quad$ Para $0<e / d \leq 10$ :

$\eta_{1}=\eta_{10}\left(1-10 \frac{e}{d}\right)$

$\eta_{2}=\eta_{20}\left(1-\eta_{20}\right)\left(10 \frac{e}{d}\right)$

- Para $e / d>10$ :

$\eta_{1}=0$

$\eta_{2}=1,0$

$e$ é a excentricidade, igual a $\frac{M_{\max , S d}}{N_{S d}}$;

$M_{\max , S d}$ é o momento máximo solicitante de cálculo em primeira ordem;

$N_{s d}$ é a força normal de compressão correspondente.

Os valores de $\eta_{10}$ e $\eta_{20}$ são definidos para $e=0$. Estes valores podem ser obtidos por meio da tabela 5.1 ou pelas seguintes expressões:

$$
\begin{aligned}
& \eta_{10}=4,9-18,5 \bar{\lambda}+17 \bar{\lambda}^{2} \quad \operatorname{com} \eta_{10} \geq 0 \\
& \eta_{20}=0,25(3+2 \bar{\lambda}) \operatorname{com} \eta_{20} \leq 1,0
\end{aligned}
$$

onde

$\bar{\lambda}$ é o índice de esbeltez reduzido, determinado pela expressão (5.50)

TABELA 5.1: Valores de $\eta_{10}$ e $\eta_{20}:$ EUROCODE 4

\begin{tabular}{|c|c|c|c|c|c|c|}
\hline $\bar{\lambda}$ & $\mathbf{0}$ & $\mathbf{0 , 1}$ & $\mathbf{0 , 2}$ & $\mathbf{0 , 3}$ & $\mathbf{0 , 4}$ & $\mathbf{2 0 , 5}$ \\
\hline $\boldsymbol{\eta}_{\mathbf{1 0}}$ & 4,90 & 3,22 & 1,88 & 0,88 & 0,22 & 0,00 \\
\hline $\boldsymbol{\eta}_{\mathbf{2 0}}$ & 0,75 & 0,80 & 0,85 & 0,90 & 0,95 & 1,00 \\
\hline
\end{tabular}

É possível notar que o acréscimo na resistência do pilar devido ao efeito de confinamento do concreto não é considerado quando o índice de esbeltez reduzido $\bar{\lambda}$ for maior que 0,5 e quando a excentricidade $e$ superar o valor de $d / 10$. 
b) Produto de Rigidez Equivalente - $(\text { EI })_{e}$

$(E I)_{e}=E I_{a}+0,8 E_{c} I_{c}+E_{s} I_{s}$

onde

$E_{c}$ é o módulo de elasticidade do concreto, dado por $E_{c m} / 1,35$;

$E_{c m}$ é o módulo de elasticidade secante do concreto;

$E_{s}$ é o módulo de elasticidade do aço da armadura;

$I_{a}, I_{c}$ e $I_{s}$ são o momento de inércia do perfil, do concreto e da armadura, respectivamente, em relação ao eixo de flexão.

Devem ser considerados os efeitos da deformação lenta quando $\bar{\lambda}$ exceder os limites da tabela 5.2 e quando $e / d<2$. Neste caso, reduz-se o valor do módulo de elasticidade do concreto para:

$E_{c}^{\prime}=E_{c}(1-0,5) \frac{N_{G, S d}}{N_{S d}}$

onde

$N_{G, S d}$ é a parcela da força normal de cálculo $N_{S d}$ que corresponde à ação permanente.

TABELA 5.2: Valores máximos de $\bar{\lambda}$ onde é permitido desprezar os efeitos da retração e da fluência, conforme o EUROCODE 4

\begin{tabular}{|l|c|c|}
\hline & Estruturas Indeslocáveis & Estruturas Deslocáveis \\
\hline Pilares revestidos & 0,8 & 0,5 \\
\hline Pilares preeenchidos & $0,8 /(1-\delta)$ & $0,5 /(1-\delta)$ \\
\hline
\end{tabular}

c) Parâmetro de contribuição do aço - $\delta$

A contribuição do aço na seção mista é dada pelo parâmetro $\delta$, definido por: 
$\delta=\left(\frac{A_{a} f_{y}}{\gamma_{a}}\right) \frac{1}{N_{p l, R d}}$

Quando $\delta$ for menor que 0,2 , a seção deve ser dimensionada como um pilar de concreto armado. Se $\delta$ for maior que 0,9 , então a seção deve ser dimensionada como um pilar de aço apenas.

d) Força normal de flambagem elástica $-N_{e}$

$N_{e}=\frac{\pi^{2}(E I)_{e}}{(K L)^{2}}$

onde

$K L$ é o comprimento efetivo de flambagem do pilar.

e) Índice de esbeltez reduzido - $\bar{\lambda}$

$\bar{\lambda}=\sqrt{\frac{N_{p l, R d}}{N_{e}}}$

onde

$N_{p l, R d}$ corresponde ao valor dado pelas expressões (5.41) ou (5.42), com os coeficientes de resistência $\gamma_{a}, \gamma_{c}$ e $\gamma_{s}$ tomados iguais a 1,0.

e) Resistência à compressão da seção mista:

A força normal de cálculo deve atender à seguinte condição, para ambos os eixos de simetria:

$N_{S d} \leq \chi N_{p l, R d}$ 
onde

$\chi$ é o fator de redução da resistência associado à flambagem, equivalente ao parâmetro $\rho$ da NBR 8800 .

\section{f) Resistência à flexo-compressão da seção mista}

Inicialmente, deve-se realizar uma verificação isolada da resistência ao momento fletor para cada eixo de simetria.

Para pilares pertencentes a estruturas indeslocáveis, os efeitos de segunda ordem podem ser desprezados se:

$\frac{N_{S d}}{N_{e}} \leq 0,1 \quad$ ou $\quad \bar{\lambda} \leq 0,2(2-r)$

onde

$r$ é a razão entre o menor e o maior momento de extremidade, obtidos em análise de primeira ordem. Esta relação é positiva no caso de curvatura simples e negativa no caso de curvatura reversa. Se houver carregamento transversal ao pilar, deve-se tomar $r$ igual a 1,0 .

Esta norma apresenta uma maneira simplificada de obter os momentos fletores de segunda ordem, que consiste em multiplicar os momentos de primeira ordem por um fator $k$, dado por:

$$
k=\frac{\beta}{1-\frac{N_{S d}}{N_{e}}}
$$

onde

$N_{S d}$ é a força normal de cálculo (compressão);

$N_{e}$ é a normal de flambagem elástica, conforme a expressão (5.49); 
$\beta$ é um fator que depende da distribuição de momentos, semelhante ao coeficiente $C_{m}$ apresentado pela NBR 8800. Quando existir carregamento transversal no pilar, $\beta$ pode ser tomado igual a 1,0 ; caso contrário, pode ser determinado por meio da seguinte expressão:

$\beta=0,66+0,44 r \geq 0,44$

- Flexo-compressão reta:

O dimensionamento é baseado na curva de interação $N \times M$, conforme a figura 5.12, e na distribuição de tensões da figura 5.13.

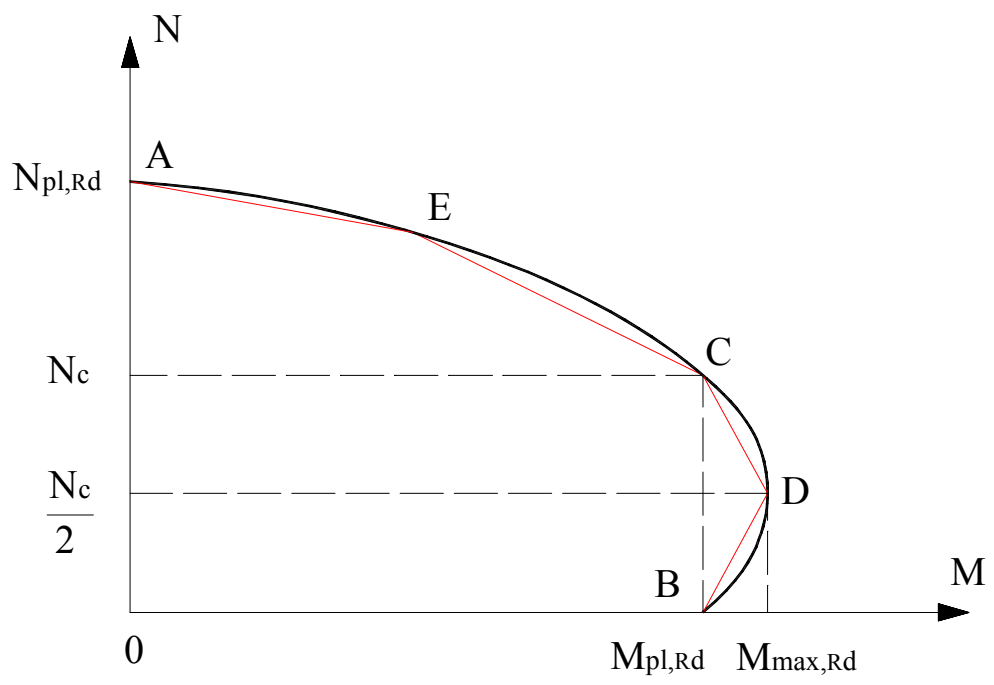

FIGURA 5.12: Diagrama de interação momento-normal da seção mista 

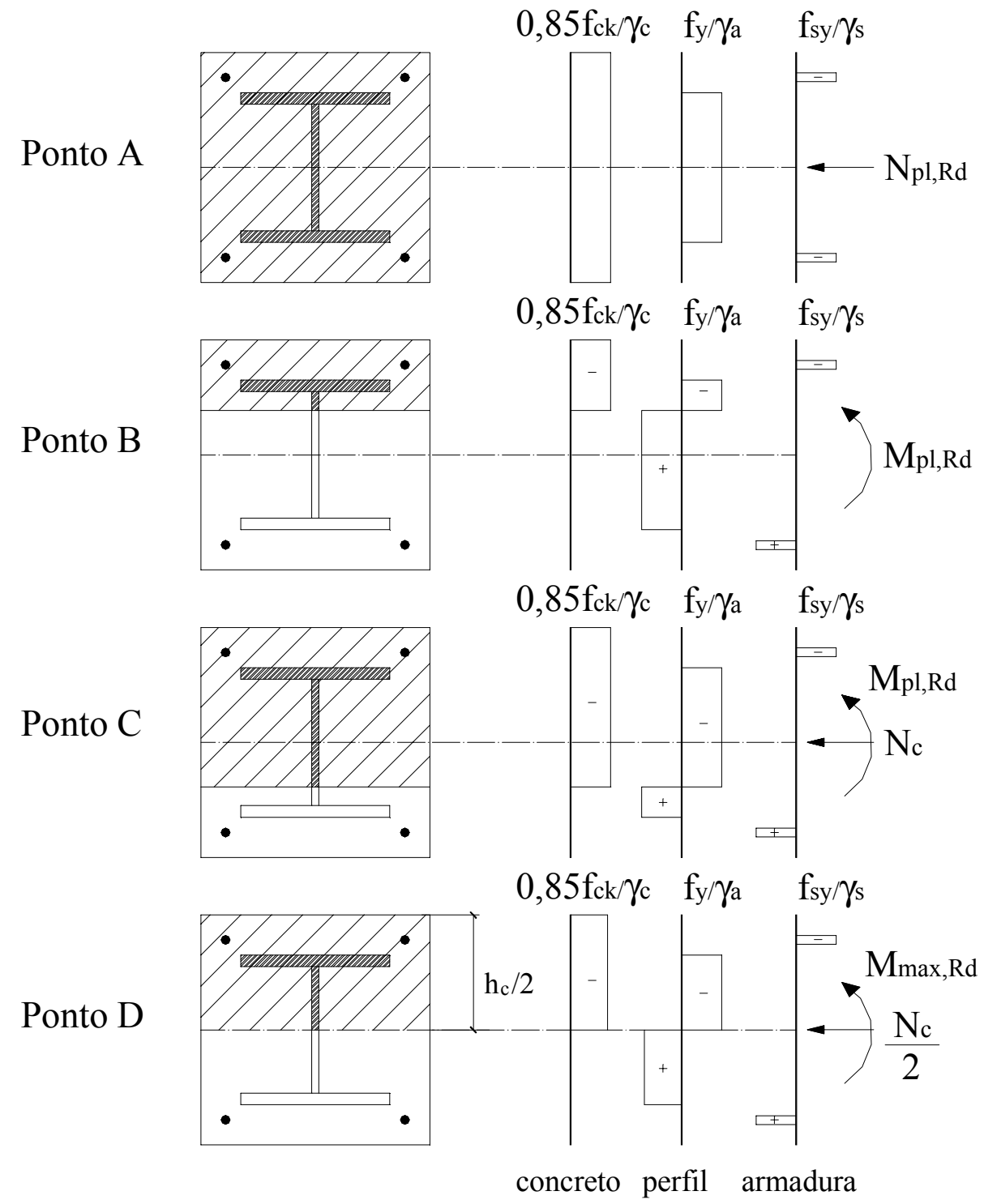

FIGURA 5.13: Distribuição de tensões correspondente ao diagrama de interação momento-normal da figura 5.12

Como simplificação, a curva do diagrama $N \times M$ pode ser representada por retas, as quais são definidas pelos pontos A, E, C, D e E. Esses pontos são determinados por:

Ponto A:

$N=N_{p l, R d}$ e $M=0$

Ponto B: 
$N=0$ e $M=M_{p l, R d}$

Ponto C:

$N=N_{c}$ e $\mathrm{M}=M_{p l, R d}$

Ponto D:

$N=1 / 2 N_{c}$ e $M=M_{\max , R d}$

onde

$N_{p l, R d}$ conforme a expressão (5.41) ou (5.42);

$M_{p l, R d}$ é o momento fletor resistente da seção mista, admitindo-se plastificação total, conforme a figura 5.13 (ponto B);

$M_{\max , R d}$ é o máximo momento resistente da seção mista, obtido segundo a distribuição de tensões da figura 5.13 no ponto $\mathrm{D}$;

$N_{c}$ é a resistência à compressão da seção de concreto, igual a $\alpha A_{c} f_{c k} / \gamma_{c}$;

$\alpha=1,0$ para pilares preenchidos e igual a 0,85 para os revestidos.

Valores da resistência ao momento fletor superiores ao momento de plastificação $M_{p l, R d}$ são normalmente desconsiderados, o que corresponde a negligenciar o ponto D no diagrama de interação. Não é necessário determinar o ponto E em seções de perfil tipo "I" fletido em torno do eixo de maior inércia ou se a força normal de cálculo não for maior que a resistência à compressão do concreto isolado $N_{c}$. Em demais casos, deve-se obter o ponto adicional E, localizado entre os pontos $\mathrm{A}$ e $\mathrm{C}$. $\mathrm{O}$ anexo $\mathrm{C}$ desta norma contém informações sobre a determinação dos pontos característicos (A à $\mathrm{E}$ ) do diagrama momento-normal.

Verifica-se a resistência do pilar misto submetido à flexo-compressão reta por meio da seguinte condição:

$$
M_{S d} \leq 0,9 \mu M_{p l, R d}
$$

onde

$M_{S d}$ é o momento solicitante de cálculo, já incluído o efeito de segunda ordem; 
$\mu=\mu_{d}-\mu_{k} \frac{\left(\chi_{d}-\chi_{n}\right)}{\left(\chi-\chi_{n}\right)}$

$\chi_{d}=\frac{N_{S d}}{N_{p l, R d}}$

$\mu_{k}$ e $\mu_{d}$ são os valores das abcissas correspondentes às ordenadas $\chi$ e $\chi_{d}$, obtidos da curva de interação, conforme a figura 5.14;

$\chi_{n}$ é um fator igual a $\chi(1-r) / 4$, para distribuição de momentos linear ou aproximadamente linear, e igual a 0 nos demais casos;

$r$ é a razão entre o menor e o maior momento de extremidade, sendo positiva no caso de curvatura simples e negativa no caso de curvatura reversa;

$\chi$ é o fator de redução da resistência associado à flambagem, equivalente ao parâmetro $\rho$ da NBR 8800 .

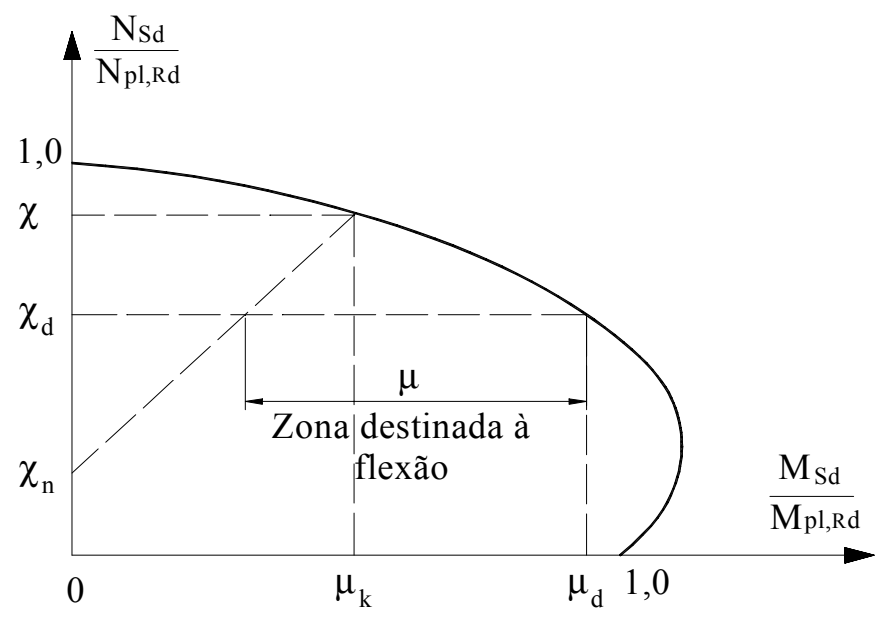

FIGURA 5.14: Procedimento de cálculo para a verificação da resistência para pilares mistos submetidos à flexão reta - EUROCODE 4.

A distância $\mu$ da figura 5.14 define a parcela do momento resistente disponível para uma dada força normal atuante. Portanto, a distância $\mu$ delimita a zona destinada à flexão; à esquerda dos pontos que definem a distância $\mu$, encontrase a zona destinada aos efeitos de segunda ordem, devido à presença da força normal.

- Flexo-compressão oblíqua: 
O procedimento de cálculo é similar ao da flexo-compressão reta, devendo-se realizar as verificações nos dois eixos de flexão $(x$ e $y)$ :

$$
\begin{aligned}
& M_{x, S d} \leq 0,9 \mu_{x} M_{x, p l, R d} \\
& M_{y, S d} \leq 0,9 \mu_{y} M_{y, p l, R d}
\end{aligned}
$$

onde

$\mu_{x}$ e $\mu_{y}$ são coeficientes determinados a partir da expressão (5.55).

Além dessas duas verificações, a expressão de interação da flexão composta deve ser satisfeita:

$$
\frac{M_{x, S d}}{\mu_{x} M_{x, p l, R d}}+\frac{M_{y, S d}}{\mu_{y} M_{y, p l, R d}} \leq 1,0
$$

\subsubsection{BS 5400: PARTE 5 (1979)}

Esta norma britânica trata do projeto de pontes constituídas de elementos mistos, abordando tanto os pilares mistos preenchidos quanto os revestidos. $\mathrm{O}$ efeito de confinamento é considerado em pilares preenchidos de seção circular. A formulação apresentada para o dimensionamento é aplicável às situações de compressão axial, flexão composta reta e flexão composta oblíqua.

- Resistência à compressão, admitindo-se plastificação total da seção - $N_{\text {pl,Rd }}$

Para pilares revestidos e pilares preenchidos retangulares:

$$
N_{p l, R d}=0,91 A_{a} f_{y}+0,87 A_{s} f_{s y}+0,45 A_{c} f_{c k}
$$

Para pilares preenchidos circulares:

$$
N_{p l, R d}=0,91 A_{a} f_{y}^{\prime}+0,45 A_{c} f_{c c}
$$


onde

$A_{a}$ é a área da seção transversal do perfil de aço;

$A_{c}$ é a área da seção transversal de concreto;

$A_{S}$ é a área da seção transversal da armadura;

$f_{y}$ é a resistência ao escoamento do aço do perfil;

$f_{c k}$ é a resistência característica do concreto à compressão;

$f_{s y}$ é a resistência ao escoamento do aço da armadura;

$f_{c c}$ é a resistência característica majorada pelo efeito de confinamento, expressa por:

$f_{c c}=f_{c k}+c_{1}\left(\frac{t}{d}\right) f_{y}$

$f_{y}$ ' é a resistência ao escoamento reduzida devido às tensões radiais desenvolvidas pelo confinamento, e expressa por:

$f_{y}^{\prime}=c_{2} f_{y}$

$t$ é a espessura da parede do tubo;

$d$ é o diâmetro externo do tubo;

$c_{1}$ e $c_{2}$ são constantes dadas na tabela 5.3. Estas constantes são análogas as constantes $\eta_{1}$ e $\eta_{2}$ apresentadas pelo EUROCODE 4, pois consideram os mesmos efeitos;

$K L$ é o comprimento efetivo de flambagem do pilar.

TABELA 5.3: Valores das constantes $c_{1}$ e $c_{2}-B S$ 5400: Parte 5 (1979)

\begin{tabular}{|c|c|c|}
\hline$K L / d$ & $c_{1}$ & $c_{2}$ \\
\hline 0 & 9,47 & 0,76 \\
\hline 5 & 6,40 & 0,80 \\
\hline 10 & 3,81 & 0,85 \\
\hline 15 & 1,80 & 0,90 \\
\hline 20 & 0,48 & 0,95 \\
\hline 25 & 0 & 1,0 \\
\hline
\end{tabular}

- Parâmetro de contribuição do concreto - $a_{c}$ 
O método apresentado pela norma britânica é restrito às seções mistas cujo parâmetro de contribuição do concreto $a_{c}$ satisfaz às seguintes limitações:

Para pilares mistos revestidos: $\quad 0,15<a_{c}<0,8$

Para pilares mistos preenchidos: $\quad 0,1<a_{c}<0,8$

onde

$a_{c}=\frac{0,45 A_{c} f_{c k}}{N_{p l, R d}} \quad$ para pilares revestidos e preenchidos retangulares $a_{c}=\frac{0,45 A_{c} f_{c c}}{N_{p l, R d}} \quad$ para pilares preenchidos circulares

$N_{p l, R d}$ conforme as expressões (5.59) ou (5.60).

- Índice de esbeltez reduzido - $\bar{\lambda}$ :

$\bar{\lambda}=\frac{K L}{L_{E}}$

onde

$K L$ é o comprimento efetivo de flambagem;

$L_{E}$ é o comprimento de flambagem do pilar para o qual a normal de flambagem elástica se iguala à resistência à compressão $N_{p l, R d}$ do pilar, admitindo-se plastificação total da seção, e dado por:

$L_{E}=\pi \sqrt{\left(\frac{E_{c} I_{c}+E I_{a}+E_{s} I_{s}}{N_{p l, R d}}\right)}$

$E_{c}$ é o módulo de elasticidade do concreto, igual a $450 f_{c k}$;

$E$ e $E_{s}$ são o módulo de elasticidade do aço do perfil e da armadura, respectivamente;

$I_{c}, I_{a}$ e $I_{s}$ são o momento de inércia da seção de concreto, do perfil e da armadura, respectivamente. 
A norma britânica apresenta ainda algumas limitações relacionadas com a esbeltez do pilar misto. A relação entre o comprimento efetivo de flambagem $K L$ e a menor dimensão da seção mista $b$ não deve ser superior a:

30 para pilares revestidos;

55 para pilares preenchidos circulares;

65 para pilares preenchidos retangulares.

O valor $b$ representa a dimensão da menor face para seções retangulares ou o diâmetro, no caso de seções circulares.

\section{- Tensões limites de aderência:}

As tensões limites de aderência são as mesmas adotadas pelo EUROCODE 4, assumindo o valor de 0,6 MPa para pilares revestidos e 0,4 $\mathrm{MPa}$ para pilares preenchidos. Quando as tensões de cisalhamento na interface forem maiores que as tensões limites de aderência, deve-se adotar conectores de cisalhamento.

\section{- Flambagem local em pilares preenchidos:}

Para evitar a ocorrência de flambagem local em perfis tubulares, a norma estabelece os seguintes limites para a espessura da parede dos tubos:

$$
\begin{aligned}
& t \geq b \sqrt{\frac{f_{y}}{3 E}} \quad \text { para pilares retangulares; } \\
& t \geq d \sqrt{\frac{f_{y}}{8 E}} \quad \text { para pilares circulares. }
\end{aligned}
$$

onde

$b$ é a largura da parede, para tubo retangular;

$d$ é o diâmetro externo, para tubo circular. 


\section{- Pilares mistos submetidos à compressão axial:}

A norma britânica faz distinção entre dois tipos de pilares, para efeito de dimensionamento:

Pilares "curtos": quando $(K L)_{x} / h_{c}$ e $(K L)_{y} / b_{c}$ forem menores que 12 ;

Pilares "esbeltos": quando $(K L)_{x} / h_{c}$ e $(K L)_{y} / b_{c}$ forem maiores que 12.

onde $(K L)_{x}$ e $(K L)_{y}$ são os comprimentos de flambagem em relação aos eixos x e y respectivamente, e $h_{c}$ e $b_{c}$ os lados da seção mista, conforme a figura 5.1.

Para os pilares curtos, a resistência à compressão é calculada por:

$N_{R d}=0,85 K_{1 y} N_{p l, R d}$

onde

$K_{l y}$ é o fator de redução associado à flambagem, semelhante ao fator $\rho$ da NBR 8800, determinado em função da esbeltez e da curva de resistência à compressão adequada. $\mathrm{O}$ apêndice $\mathrm{C}$ desta norma apresenta uma tabela para a determinação deste coeficiente.

O valor 0,85 corresponde a um fator de redução que considera eventuais excentricidades acidentais durante a fase construtiva.

Os pilares esbeltos submetidos à compressão axial devem ser considerados como elementos flexo-comprimidos, com flexão em torno do eixo de menor inércia. Neste caso, a norma adota como excentricidade para a força normal de cálculo o valor $0,03 b$, onde $b$ é o menor lado da seção transversal do pilar misto. Os pilares esbeltos submetidos à flexo-compressão reta são tratados como pilares submetidos à flexo-compressão oblíqua, devido à excentricidade acidental que deve ser incluída. A verificação de elementos flexo-comprimidos é apresentada a seguir.

\section{- Elementos flexo-comprimidos:}


A norma britânica apresenta a formulação para a verificação de quatro situações possíveis de flexo-compressão:

a) Pilares submetidos à flexão em torno do eixo de menor inércia (y):

Devem ser feitas duas verificações:

- O momento solicitante de cálculo $M_{y, S d}$ não deve ser superior ao momento resistente $M_{y, p l, R d}$, admitindo-se a plastificação total da seção. Para levar em conta eventuais excentricidades de execução, o momento solicitante de cálculo $M_{y, S d}$ também não deve ser superior ao produto da força normal de cálculo por $0,03 b$, conforme já mencionado;

- A força normal de cálculo $N_{S d}$ não deve ser superior à normal resistente $N_{y}$ :

$N_{y}=N_{p l, R d}\left(K_{1 y}-\left(K_{1 y}-K_{2 y}-4 K_{3}\right) \frac{M_{y, S d}}{M_{y, p l, R d}}-4 K_{3}\left(\frac{M_{y, S d}}{M_{y, p l, R d}}\right)^{2}\right)$

onde

$K_{l y}$ e $K_{2 y}$ são coeficientes determinados para o eixo y, de acordo com o apêndice C desta norma;

$K_{3}$ é um coeficiente também determinado de acordo com o apêndice $\mathrm{C}$ desta norma.

b) Pilares submetidos à flexão no eixo de maior inércia (x), restritos no eixo de menor inércia:

Quando as condições de vinculação são tais que impeçam a flambagem do pilar no eixo de menor inércia, deve-se considerar, além da condição de o momento solicitante de cálculo $M_{x, S d}$ não superar o momento resistente $M_{x, p l, R d}$, que a força normal de cálculo $N_{S d}$ não seja superior à normal resistente $N_{x}$ : 
$N_{x}=N_{p l, R d}\left(K_{1 x}-\left(K_{1 x}-K_{2 x}-4 K_{3}\right) \frac{M_{x, S d}}{M_{x, p l, R d}}-4 K_{3}\left(\frac{M_{x, S d}}{M_{x, p l, R d}}\right)^{2}\right)$

onde

$K_{1 x}$ e $K_{2 x}$ são coeficientes determinados para o eixo x, de acordo com o apêndice C desta norma.

O momento solicitante $M_{x, S d}$ não deve ser tomado menor que $0,03 b \mathrm{~N}_{S d}$.

c) Pilares submetidos à flexão no eixo de maior inércia (x), não restritos no eixo de menor inércia:

Quando as condições de vinculação permitem a possibilidade de flambagem do pilar em torno do eixo de menor inércia, além da condição $M_{x, S d}<M_{x, p l, R d}$, deve-se limitar a força normal de cálculo $N_{S d}$ à normal resistente $N_{x y}$, determinada para a flexão oblíqua, conforme a expressão (5.66). Deve-se atribuir ao momento $M_{y, S d} \mathrm{O}$ valor $0,03 b N_{S d}$, decorrente da excentricidade acidental.

d) Pilares submetidos à flexão oblíqua:

Neste caso, o pilar misto deve ser dimensionamento de modo que:

- $M_{x, S d}<M_{x, p l, R d} \quad$ e $\quad M_{y, S d}<M_{y, p l, R d}$

- $\quad N_{S d}$ não deve ser superior a normal resistente $N_{x y}$ para a flexão oblíqua, calculada por meio da seguinte expressão:

$$
\frac{1}{N_{x y}}=\frac{1}{N_{x}}+\frac{1}{N_{y}}-\frac{1}{K_{1 x} N_{p l, R d}}
$$


O apêndice $\mathrm{C}$ desta norma fornece a formulação para o cálculo dos momentos fletores resistentes, tanto em pilares mistos revestidos quanto em pilares preenchidos, considerando a plastificação total da seção mista.

Para a melhor compreensão da procedência dos coeficientes $K_{1}, K_{2}$ e $K_{3}$, a figura 5.15 ilustra graficamente a curva de interação momento-normal e a simplificação adotada pela norma britânica:

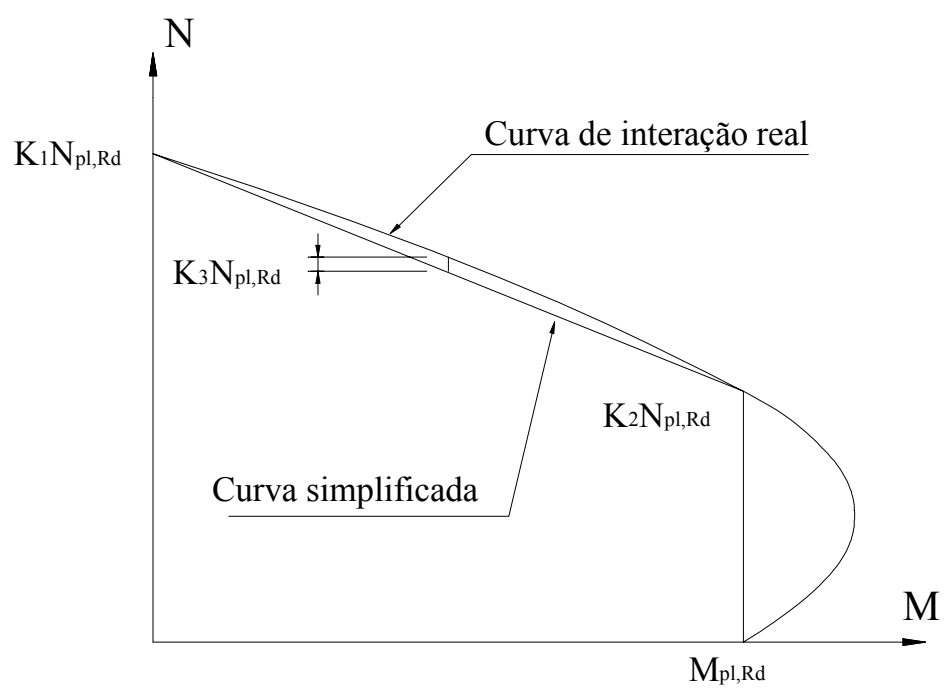

FIGURA 5.15: Simplificação da norma BS 5400: Parte 5 (1979) para a curva de interação momento-normal

\subsection{CONSIDERAÇÕES ADICIONAIS}

Alguns pesquisadores, com o objetivo de contribuir para o projeto dos pilares mistos, propuseram novos procedimentos de cálculo relacionados com o dimensionamento.

MIRZA \& TIKKA (1999) propuseram duas expressões para o cálculo da rigidez equivalente $(E I)_{e}$ de pilares mistos revestidos e esbeltos submetidos à flexão no eixo de maior inércia. Com o objetivo de fornecer dados para o desenvolvimento das expressões propostas, simularam aproximadamente doze mil pilares, cada pilar apresentando uma combinação diferente das propriedades dos materiais, tal como a resistência característica do concreto à compressão $\left(f_{c k}\right)$, a resistência ao escoamento 
do aço do perfil $\left(f_{y}\right)$, a relação da área da seção transversal do perfil de aço e da área de armadura longitudinal com a área de concreto. As expressões propostas são:

$(E I)_{e}=\left[\left(0,27+0,003 \frac{l}{h}-0,2 \frac{e}{h}\right) E_{c}\left(I_{c}-I_{a}\right)+0,8 E\left(I_{a}+I_{s}\right)\right] \geq E I_{a}$

ou, alternativamente,

$(E I)_{e}=\left[\left(0,3-0,2 \frac{e}{h}\right) E_{c}\left(I_{c}-I_{a}\right)+0,8 E\left(I_{a}+I_{s}\right)\right] \geq E I_{a}$

onde

$l$ é o comprimento do pilar, dado pela distância entre centros de vinculação;

$e$ é a excentricidade da força normal;

$h$ é a altura da seção mista, medida perpendicularmente ao eixo de flexão;

$E_{c}$ é o módulo de elasticidade do concreto;

$E$ é o módulo de elasticidade do aço;

$I_{c}, I_{a}$ e $I_{s}$ são o momento de inércia da seção de concreto, do perfil de aço e da armadura longitudinal, respectivamente, em relação ao eixo que intercepta o centro de gravidade da seção mista.

A expressão (5.68) é um pouco mais conservadora para relações $l / h>10$.

WANG (1999) realizou um estudo sobre pilares mistos esbeltos, preenchidos e revestidos, baseado em resultados de uma série de ensaios nos quais se aplicaram forças axiais excêntricas aos pilares, submetendo-os à flexo-compressão. $\mathrm{O}$ autor propôs um novo procedimento de verificação de pilares mistos flexo-comprimidos, que encontra base nos critérios da BS 5400: Parte 1 para os pilares de aço, mas que também pode ser comparado às verificações recomendadas pelo EUROCODE 4. O principal mérito deste procedimento é a simplicidade. Realiza-se a verificação da flexo-compressão por meio de duas expressões propostas. A primeira considera os efeitos locais, e a segunda os efeitos da instabilidade global: 
Verificação da capacidade local:

$$
\frac{N_{S d}}{N_{p l, R d}}+\frac{M_{x, S d}}{M_{x, p l, R d}}+\frac{M_{y, S d}}{M_{y, p l, R d}} \leq 1,0
$$

Verificação dos efeitos globais:

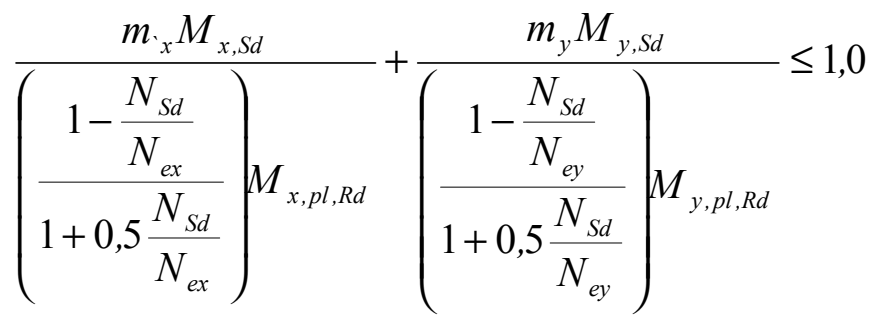

onde

$m_{x}$ e $m_{y}$ são fatores de equivalência de carregamento, semelhante ao parâmetro $C_{m}$ da norma brasileira NBR 8800;

$N_{e x}$ e $N_{e y}$ são as normais de flambagem elástica nos eixos x e y respectivamente. 


\section{PROJETO EM SITUAÇÃO DE INCÊENIO}

\subsection{INTRODUÇÃO}

A principal conseqüência da ocorrência de incêndio em um edifício é a possibilidade de perda de vidas humanas. Porém, as conseqüências se estendem também a grandes prejuízos econômicos, devido aos danos causados às propriedades. Em edifícios industriais e comerciais, o prejuízo pode ser maior devido à interrupção das atividades. Existe ainda o problema do impacto ambiental, causado pela combustão de grande quantidade de material. Assim, os objetivos do projeto de segurança contra incêndio têm sido direcionados à proteção à vida e à minimização das perdas econômicas.

Com relação ao projeto estrutural que leva em consideração a ação do fogo, existe a necessidade de compatibilização, sob o ponto de vista econômico, entre o custo da segurança adicional para proteção ao fogo e o custo do empreendimento. Esse aspecto assume vital importância, pois estabelecer critérios racionais de proteção ao fogo pode evitar a inviabilidade econômica do projeto, principalmente no caso de pequenos edifícios. Segundo LAWSON (1990), os custos destinados à proteção térmica de elementos de aço correspondem, em média, a 20\% do custo da estrutura metálica.

A aplicação dos conceitos de engenharia à segurança contra incêndio, em edifícios, é relativamente recente. No Brasil, está em estudo a aprovação de uma norma que trará critérios de segurança contra o incêndio em edificações. Com relação ao projeto estrutural, aprovou-se recentemente a norma NBR 14323 (1999): "Dimensionamento de estruturas de aço de edifícios em situação de incêndio", incluindo os elementos mistos aço-concreto. A elaboração dessa nova norma teve 
como base o EUROCODE 4: Parte 1.2 (1995): "Design of composite steel and concrete structures. General rules. Structural fire design”, o qual consiste em um documento técnico resultante da pesquisa de grandes centros de tecnologia nesta área.

Sob o aspecto estrutural, temperaturas elevadas provocam uma alteração nas propriedades dos materiais, reduzindo suas resistências. Essa redução no aço e no concreto é apresentada no item 6.3.

A resistência de um elemento de aço ao fogo corresponde ao tempo, indicado usualmente em minutos, necessário para se atingir o colapso estrutural, estando submetido à uma condição de incêndio preestabelecida ou padronizada, conforme explicado no item 6.2 .

\subsection{AÇÃO TÉRMICA}

\subsubsection{CURVAS TEMPO ${ }_{X}$ TEMPERATURA}

A curva tempo-temperatura fornece a temperatura dos gases em função do tempo de incêndio, sendo possível, a partir dessa curva, obter a máxima temperatura atingida pelo elemento estrutural e, consequentemente, sua resistência ao incêndio. A figura 6.1 ilustra a curva típica tempo-temperatura de um edifício em situação de incêndio real. 


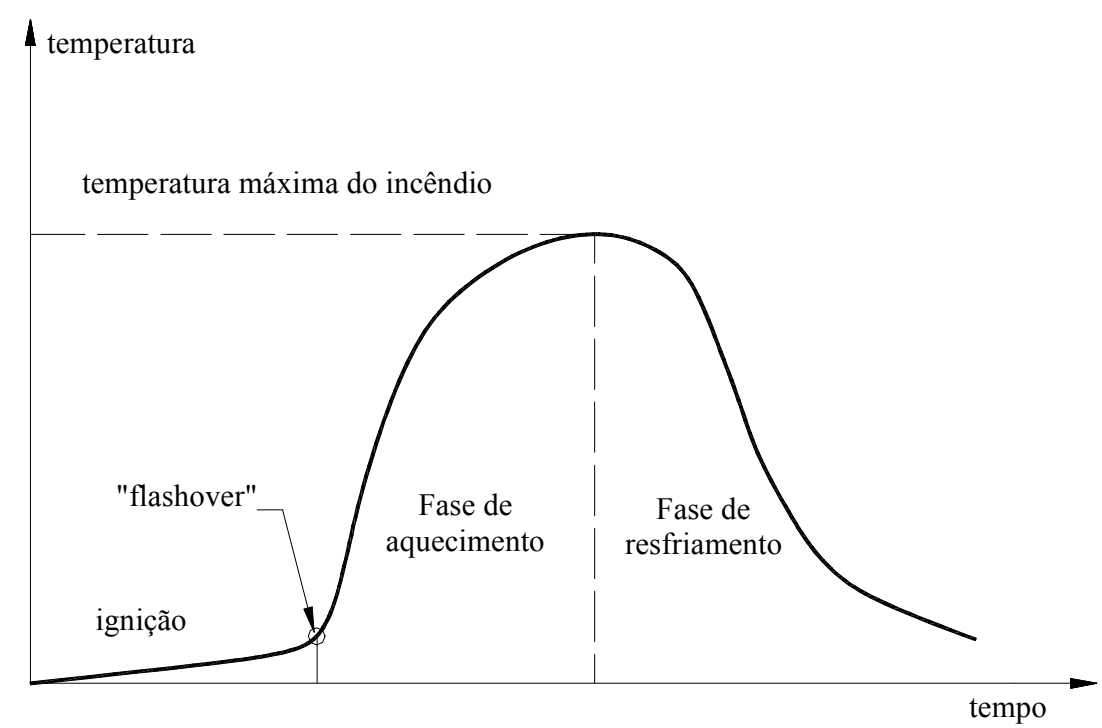

FIGURA 6.1: Curva tempo-temperatura de um edifício em situação de incêndio real

O trecho inicial da curva (fase de ignição) é caracterizado por um aumento de temperatura relativamente pequeno, proporcionando poucos riscos à estrutura. Após a fase de ignição, segue-se um aumento brusco da temperatura, quando a superfície de todos os materiais combustíveis presentes no ambiente entra em ignição. O instante em que se dá esse aumento brusco da temperatura é conhecido como flashover. Após o flashover, a temperatura dos gases eleva-se rapidamente, caracterizando a fase de aquecimento, até boa parte do material combustível extinguir-se, dando início à fase de resfriamento.

O desenvolvimento das etapas que caracterizam um incêndio real depende de uma série de fatores, tais como a quantidade, a natureza, e a distribuição do material combustível, do grau de ventilação do ambiente e dos materiais de vedação que impedem a propagação do incêndio no compartimento.

Devido à enorme dificuldade de se estabelecer a curva tempo-temperatura de um incêndio real, justificada pela grande sensibilidade dessa curva aos fatores mencionados, as principais normas que abordam o assunto adotam curvas padronizadas, denominadas curvas de incêndio padrão. Essas curvas contém apenas um ramo ascendente, diferente da curva de um incêndio real, mostrada na figura 6.1. As curvas de incêndio padrão são apenas um modelo teórico e simplificado, cujo objetivo é representar os mesmos efeitos máximos dos produzidos por um incêndio real. 
As principais curvas de incêndio padrão são as fornecidas pela ISO 834 (1975): "Fire resistance tests - Elements of building construction" e pela ASTM E119 (1988): "Standard test methods for fire tests of building construction and materials".

A curva tempo-temperatura apresentada pela ISO 834 é construída a partir de uma função logarítmica, expressa por:

$T-T_{0}=345 \log (8 t+1)$

onde

$t$ é o tempo, em minutos;

$T$ é a temperatura no instante $t, \mathrm{em}^{\circ} \mathrm{C}$;

$T_{0}$ é a temperatura inicial, adotada como $20^{\circ} \mathrm{C}$.

A ASTM E119 recomenda a utilização da tabela 6.1 para a construção da curva tempo-temperatura:

TABELA 6.1: Valores tempo x temperatura - ASTM E119 (1988). Reproduzido de SILVA (1997)

\begin{tabular}{|c|c|c|c|}
\hline $\begin{array}{c}\text { Tempo } \\
\text { (min.) }\end{array}$ & $\begin{array}{c}\text { Temperatura } \\
{ }^{\circ} \boldsymbol{C}\end{array}$ & $\begin{array}{c}\text { Tempo } \\
\text { (min.) }\end{array}$ & $\begin{array}{c}\text { Temperatura } \\
{ }^{\circ} \boldsymbol{C}\end{array}$ \\
\hline 0 & 20 & 55 & 916 \\
\hline 5 & 538 & 60 & 927 \\
\hline 10 & 704 & 65 & 937 \\
\hline 15 & 760 & 70 & 946 \\
\hline 20 & 795 & 75 & 955 \\
\hline 25 & 821 & 80 & 963 \\
\hline 30 & 843 & 85 & 971 \\
\hline 35 & 862 & 90 & 978 \\
\hline 40 & 878 & 120 & 1010 \\
\hline 45 & 892 & 240 & 1093 \\
\hline 50 & 905 & 480 & 1260 \\
\hline
\end{tabular}

A figura 6.2 ilustra uma comparação entre as curvas de incêndio padrão apresentadas pela ISO 834 (1975) e pela ASTM E119 (1988). 


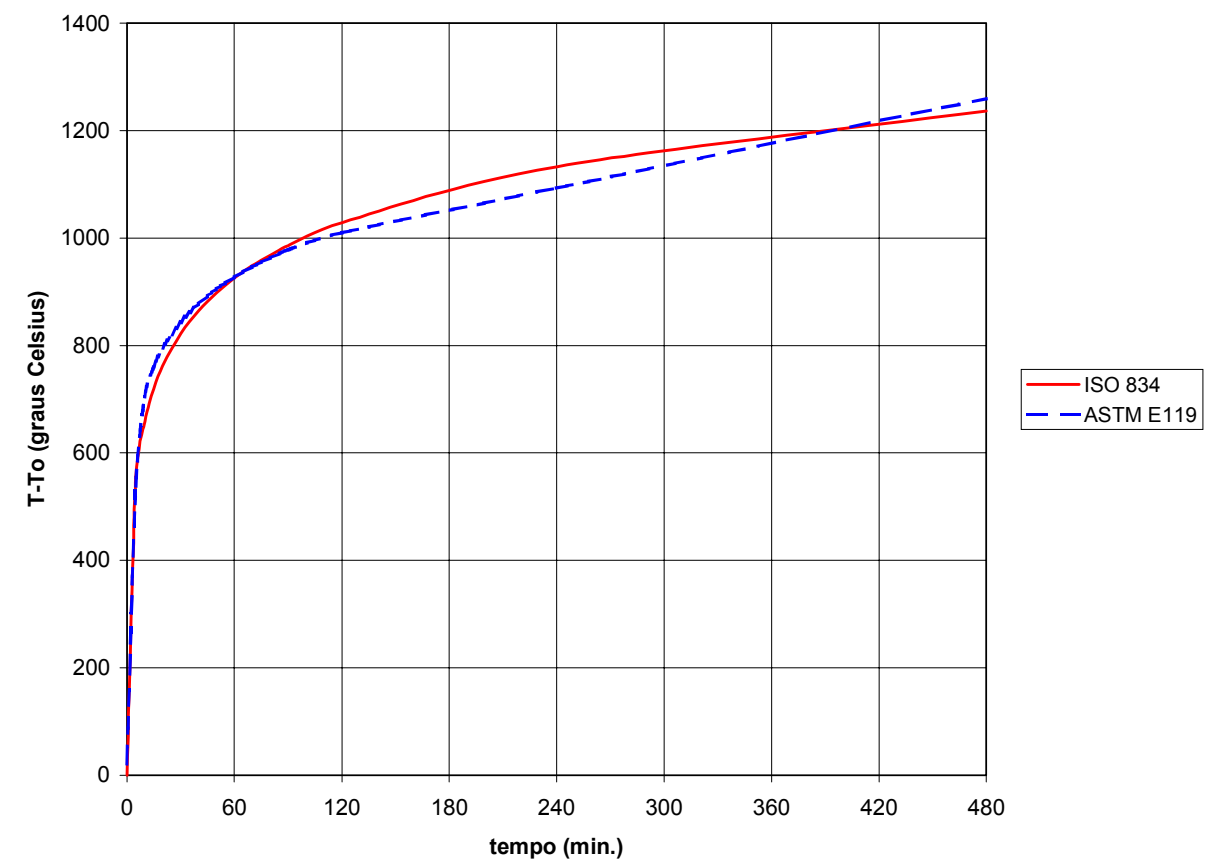

FIGURA 6.2: Comparação entre as curvas tempo-temperatura fornecidas pela ISO 834 (1975) e pela ASTM E119 (1988)

A norma brasileira NBR 5628 (1980): “Componentes construtivos estruturais: determinação da resistência ao fogo" adota a mesma curva tempo-temperatura da ISO 834.

Existem ainda as curvas de incêndio natural, as quais são construídas a partir de ensaios que simulam a situação real de um incêndio de um compartimento em chamas. A característica principal destas curvas é o fato de possuírem um ramo ascendente, que corresponde à fase de aquecimento, e um ramo descendente, que corresponde à fase de esfriamento.

A partir das curvas de incêndio natural, é possível determinar a máxima temperatura atingida pelo aço, possibilitando o dimensionamento com base nessa temperatura. $\mathrm{O}$ mesmo não ocorre quando se utilizam as curvas de incêndio padrão, pois, pelo fato de não possuírem o ramo descendente, torna-se impossível obter a temperatura máxima. $O$ procedimento adotado quando se usam as curvas de incêndio padrão é preestabelecer um tempo fictício de dimensionamento e encontrar a temperatura por meio da curva padrão. Esses tempos são padronizados em função do tipo de ocupação do edifício e de suas dimensões. 
Os ensaios que possibilitam a construção das curvas de incêndio natural são realizados em áreas compartimentadas, onde não há a possibilidade de propagação do incêndio para fora delas. Esses ensaios demostram que a curva de incêndio natural depende da quantidade de material combustível (carga de incêndio) e do grau de ventilação.

A carga de incêndio é expressa como a quantidade de madeira termicamente equivalente à soma de todo o material combustível do compartimento analisado, por unidade de área de piso (usualmente em $\mathrm{kg} / \mathrm{m}^{2}$ ). A carga de incêndio $q$ por unidade de área é expressa por:

$$
q=\frac{\sum M_{r} H_{r}}{A_{t}}
$$

onde

$M_{r}$ é a massa total de cada componente do material combustível, em kg;

$H_{r}$ é o potencial calorífico específico de cada componente da carga de incêndio, em $\mathrm{MJ} / \mathrm{kg}$;

$A_{t}$ é a área total de vedações (paredes, piso e teto), em $\mathrm{m}^{2}$.

O grau de ventilação é representado pelo fator de abertura $v$, o qual é dado por:

$v=\frac{A \sqrt{h}}{A_{t}}$

onde

$v$ é o fator de abertura, em $\mathrm{m}^{1 / 2}$;

$A$ é a área total das aberturas para o ambiente externo ao edifício, incluindo janelas, que se supõem quebradas durante um incêndio;

$h$ é a altura média das aberturas, igual a $\sum \frac{h_{i} A_{i}}{A}$;

$A_{i}$ é a área da abertura i; 
$h_{i}$ é a altura da abertura i, sendo $\sum A_{i}=A$.

Quanto maior for a quantidade de material combustível, maior a duração do incêndio e, portanto, maior a temperatura máxima alcançada pela estrutura de aço. Por sua vez, quanto maior for o grau de ventilação, menor será a duração do incêndio.

\subsubsection{FATOR DE MASSIVIDADE}

O fator de massividade é um parâmetro que está relacionado diretamente à temperatura atingida pela estrutura de aço. $\mathrm{O}$ fator de massividade (ou fator de forma da seção) é a relação entre o perímetro exposto ao fogo e a área da seção:

Fator de massividade $=\frac{u}{A}$, expresso usualmente em $\mathrm{m}^{-1}$

Quanto maior o fator de forma da seção, maior será a temperatura atingida pelo perfil, para uma mesmo tempo de exposição. Esse parâmetro encontra uma analogia com a esbeltez, em sentido estrutural. As tabelas 6.2 e 6.3 contém o cálculo do fator de massividade para elementos estruturais sem e com proteção térmica.

Em edifícios, de maneira geral, o fator de massividade das vigas de aço é menor que o dos pilares, pois aquelas apresentam uma face a menos exposta ao fogo, devido à presença da laje. 
TABELA 6.2: Fator de massividade para elementos estruturais sem proteção

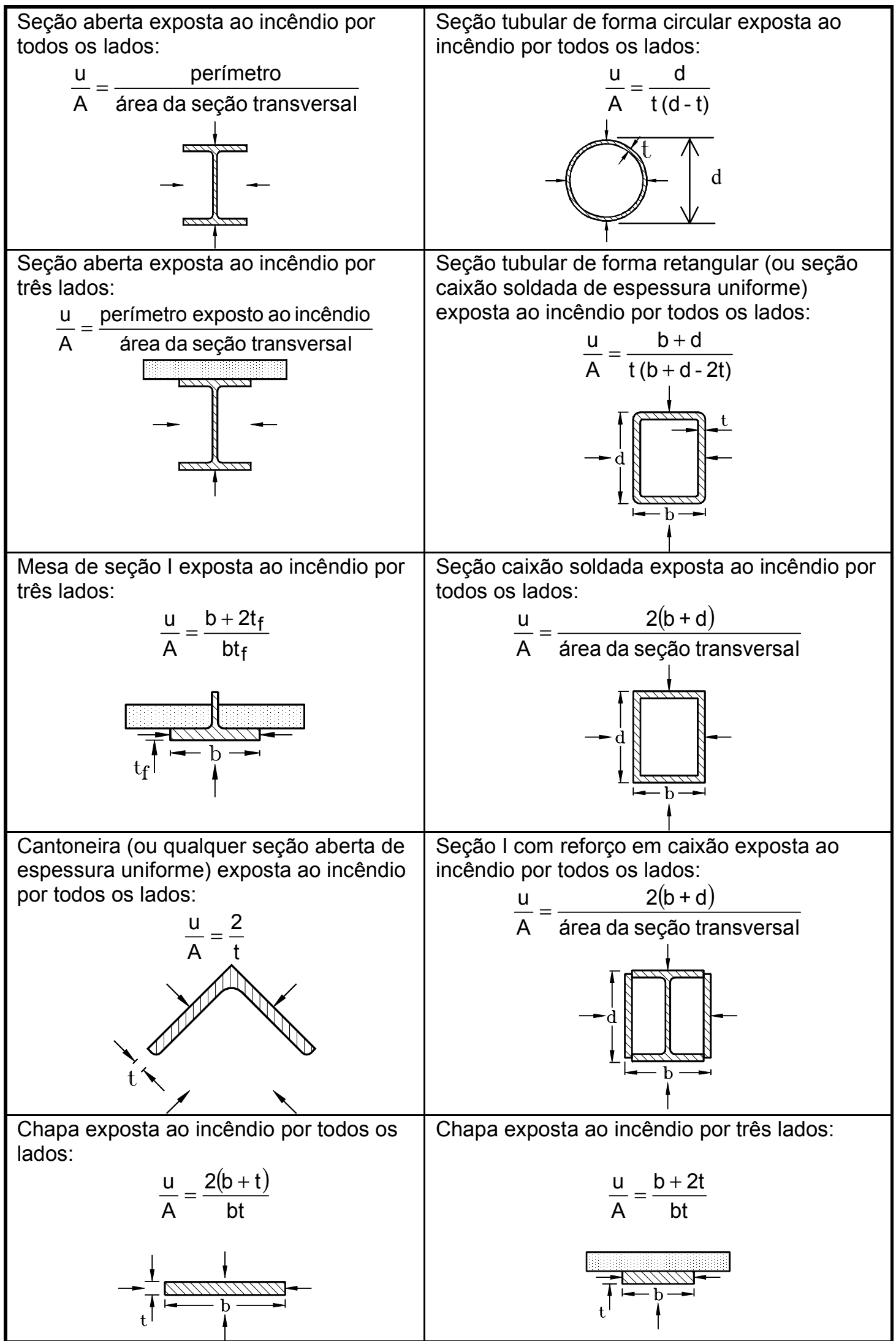


TABELA 6.3: Fator de massividade para elementos estruturais com proteção

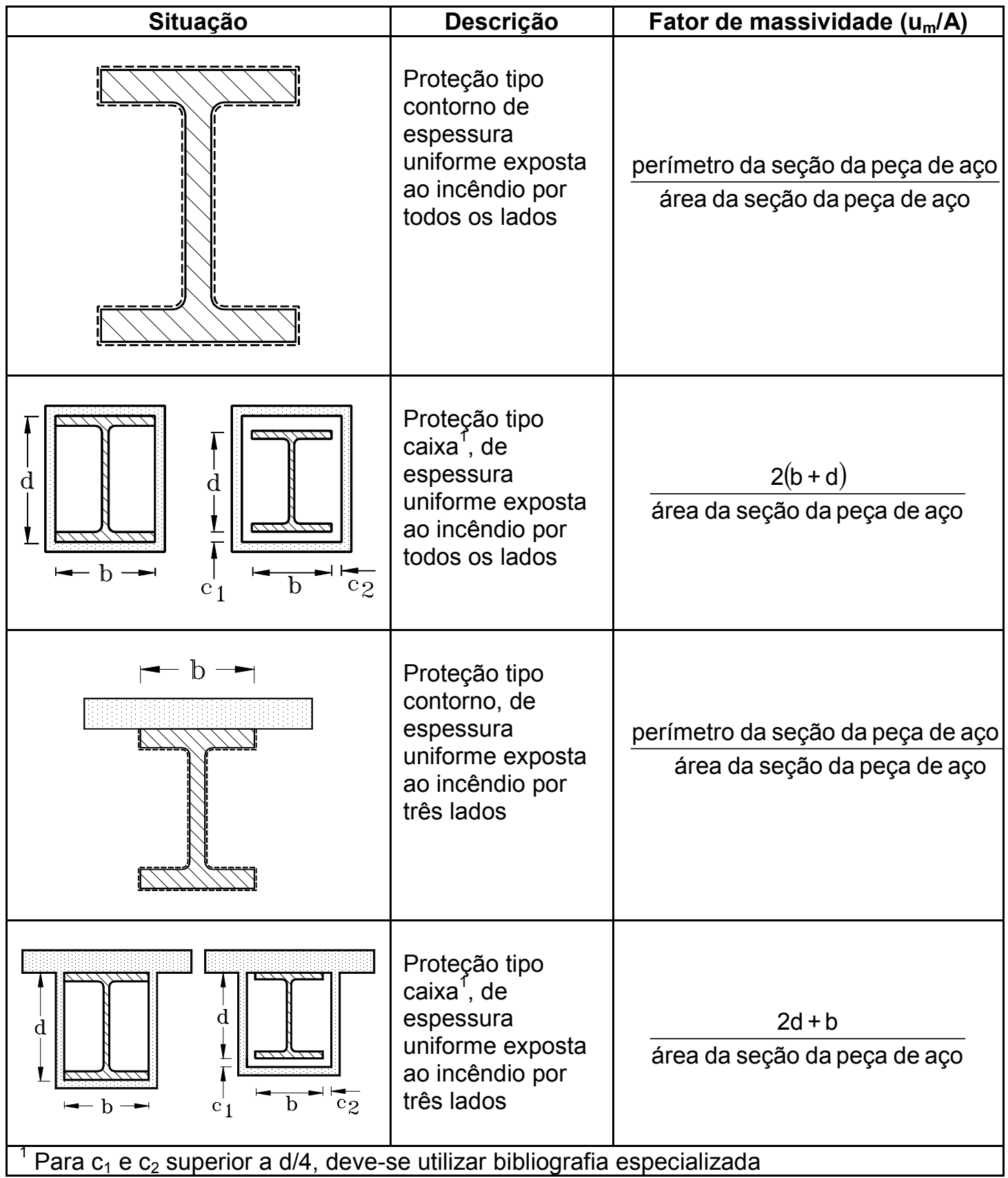

\subsubsection{PROTEÇÃO DE ESTRUTURAS DE AÇO AO FOGO}

Os materiais de proteção devem cumprir a função de proteger as estruturas de aço à ação direta ao fogo, aumentando também a sua resistência em situação de incêndio. Para exercerem esse papel, esses materiais devem apresentar baixa condutividade térmica, baixa densidade, boa resistência mecânica a altas temperaturas e durabilidade à temperatura ambiente. 
DIAS (1998) apresenta diversos tipos de materiais de proteção, além de algumas técnicas utilizadas para prover proteção ao fogo. Uma das técnicas tradicionais é o encapsulamento dos elementos de aço por materiais constituintes de alvenaria, por meio de concretagem ou ainda pela utilização de placas rígidas de gesso e vermiculita, argamassa de vermiculita, mantas de lã-de-rocha e cerâmicas. Os produtos mais recentes são as pinturas intumescentes e as argamassas compostas de gesso e fibras.

As argamassas de vermiculita são constituídas de agregado leve, à base de vermiculita, a qual é originada da alteração das micas. A vermiculita, quando aquecida, intumesce e se expande, chegando a apresentar um peso próprio muito baixo $\left(100\right.$ a $\left.130 \mathrm{~kg} / \mathrm{m}^{3}\right)$ quando comparado a areia $\left(1600 \mathrm{~kg} / \mathrm{m}^{3}\right)$. Seu ponto de fusão chega em torno de $1370^{\circ} \mathrm{C}$.

As mantas de fibra cerâmica apresentam uma boa resistência ao manuseio e podem ser utilizadas revestindo-se o elemento de aço em todo o seu contorno, por meio de pinos e arruelas de aço. Seu ponto de fusão é de $1260^{\circ} \mathrm{C}$. Pelo fato de não resistirem à umidade e à abrasão, as mantas cerâmicas devem ser empregadas em locais cobertos e protegidos por algum tipo de acabamento superficial.

A lã de rocha é produzida a partir da alteração de pedras basálticas, estando suas fibras dispostas de forma aleatória. A lã de rocha apresenta ponto de fusão acima de $1200^{\circ} \mathrm{C}$. Os elementos de aço podem ser revestidos em forma de caixa ou aplicados no contorno do perfil de aço.

As pinturas intumescentes possuem a propriedade de retardar a elevação da temperatura do elemento de aço. Essa elevação de temperatura produz um aumento do volume da camada da pintura, podendo aumentar a espessura da película em cerca de quarenta vezes, dando o aspecto de uma esponja, que age como isolante térmico. As pinturas intumescentes são sensíveis à umidade, o que restringe seu uso ao interior de edifícios, na maioria dos casos.

Em argamassas compostas de gesso e fibras, a elevada temperatura faz com que o conteúdo de água no gesso comece a evaporar, retardando a transmissão de calor e propiciando ao material protegido uma considerável resistência térmica. As fibras são colocadas para evitar que o gesso se desintegre sob altas temperaturas. 
Devido ao comportamento do gesso em presença de umidade, sua utilização também é restrita a locais protegidos da ação direta do intemperismo.

\subsection{PROPRIEDADES MECÂNICAS DO AÇO E DO CONCRETO SOB TEMPERATURAS ELEVADAS}

Tanto o aço quanto o concreto têm suas propriedades mecânicas alteradas sob elevadas temperaturas. Isso pode ser traduzido pela redução no módulo de elasticidade dos dois materiais e pela redução da resistência ao escoamento do aço e da resistência à compressão do concreto.

Diversos trabalhos foram desenvolvidos a fim de avaliar a influência das altas temperaturas sobre as propriedades do aço.

SILVA (1997) cita alguns trabalhos que tiveram por objetivo determinar o diagrama tensão-deformação dos aços estruturais submetidos a elevadas temperaturas.

O ECCS (1985): "Design Manual on the European Recomendations for the Fire Safety of Steel Structures" fornece tabelas com valores de tensão e deformação em temperaturas que variam de $20^{\circ} \mathrm{C}$ a $600^{\circ} \mathrm{C}$, limitando a deformação específica correspondente ao escoamento em $0,5 \%$. O gráfico da figura 6.3 é obtido a partir dessas tabelas, para aços $\operatorname{com} f_{y}=235 \mathrm{MPa}$. 


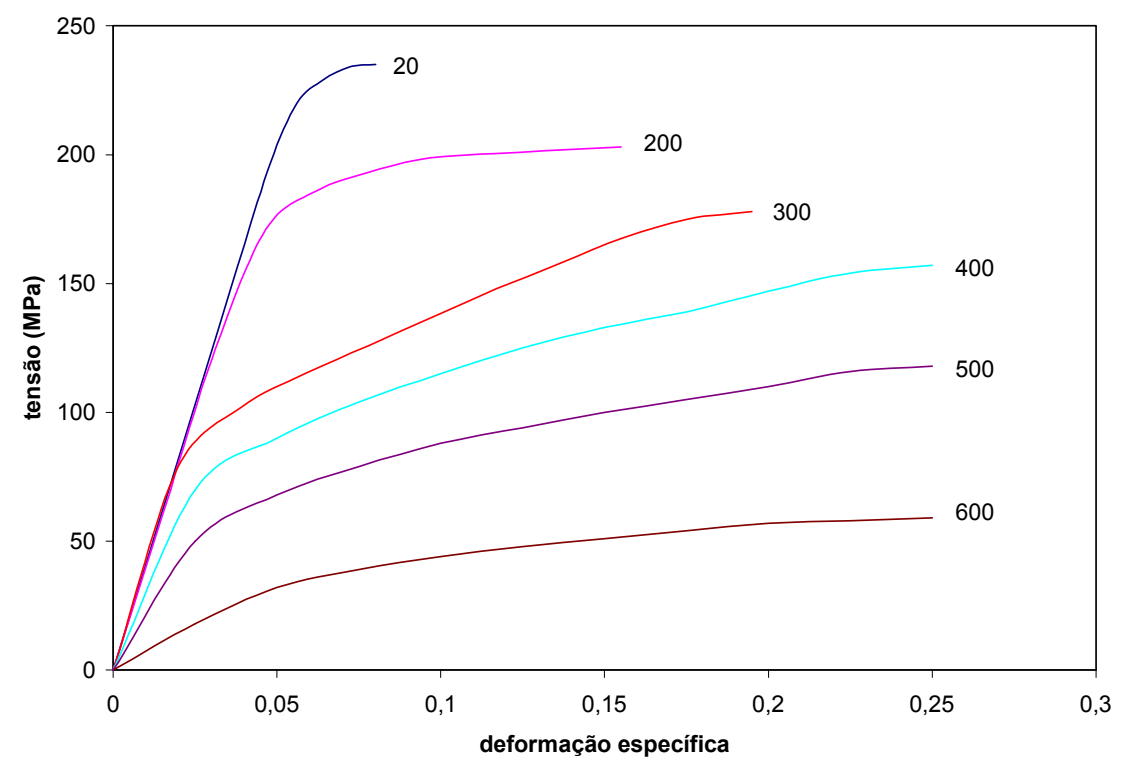

FIGURA 6.3: Diagrama tensão-deformação do aço $\left(f_{y}=235 \mathrm{MPa}\right)$ para temperaturas de $20^{\circ} \mathrm{C}$ a $600^{\circ} \mathrm{C}$.

O EUROCODE 4 adota um modelo matemático para o diagrama tensãodeformação do aço a elevadas temperaturas (figura 6.4). A tabela 6.4 contém as equações que definem o diagrama tensão-deformação para os três trechos distintos desse diagrama.

O EUROCODE 4 apresenta os valores de redução a serem aplicados à resistência ao escoamento do aço, à resistência correspondente ao limite de proporcionalidade e ao módulo de elasticidade tangente, em função das propriedades mecânicas, à temperatura de $20^{\circ} \mathrm{C}$. A norma brasileira NBR 14323 (1999) adota os mesmos fatores de redução para o limite de escoamento e o módulo de elasticidade indicados pelo EUROCODE 4 (ver tabela 6.5). 


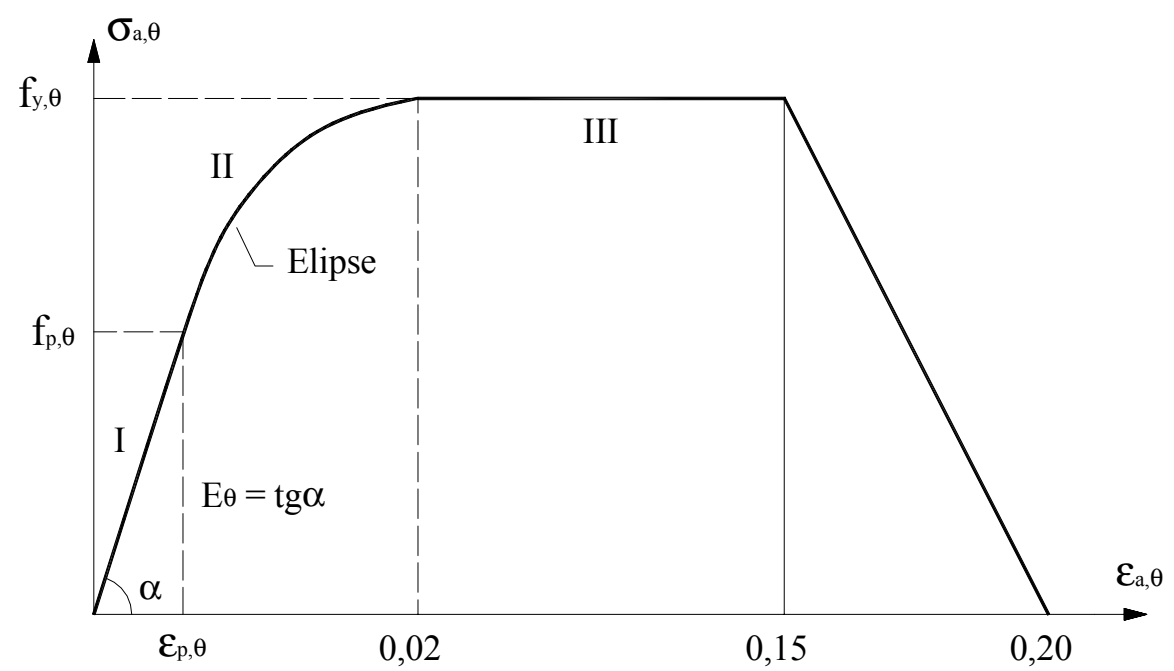

FIGURA 6.4: Diagrama tensão-deformação do aço para temperaturas elevadas EUROCODE 4.

TABELA 6.4: Parâmetros que definem o diagrama tensão-deformaçãoEUROCODE 4

\begin{tabular}{|c|c|c|}
\hline $\begin{array}{l}\text { Intervalo de } \\
\text { deformações }\end{array}$ & $\sigma_{\mathrm{a}, \theta}$ & $\mathbf{E}_{\theta}$ \\
\hline $\begin{array}{c}\text { Trecho elástico } \\
\text { (I) } \\
\varepsilon \leq \varepsilon_{\mathrm{p}, \theta} \\
\end{array}$ & $\sigma_{a, \theta}=\varepsilon_{a, \theta} E_{\theta}$ & $E_{\theta}$ \\
\hline $\begin{array}{c}\text { Transição elíptica } \\
\text { (II) } \\
\varepsilon_{\mathrm{p}, \theta}<\varepsilon \leq 0,02\end{array}$ & $\begin{array}{l}\sigma_{a, \theta}=\frac{b}{a} \sqrt{a^{2}-\left(\varepsilon_{y, \theta}-\varepsilon_{a, \theta}\right)^{2}}+f_{p, \theta}-c \\
\text { onde } \\
a^{2}=\left(\varepsilon_{y, \theta}-\varepsilon_{p, \theta}\left(\varepsilon_{y, \theta}-\varepsilon_{p, \theta}+\frac{c}{E_{\theta}}\right)\right. \\
b^{2}=E_{\theta}\left(\varepsilon_{y, \theta}-\varepsilon_{p, \theta}\right) c+c^{2} \\
c=\frac{\left(f_{y, \theta}-f_{p, \theta}\right)^{2}}{E_{\theta}\left(\varepsilon_{y, \theta}-\varepsilon_{p, \theta}\right)-2\left(f_{y, \theta}-f_{p, \theta}\right)}\end{array}$ & $E_{\theta}=\frac{b\left(\varepsilon_{y, \theta}-\varepsilon_{a, \theta}\right)}{a \sqrt{a^{2}-\left(\varepsilon_{y, \theta}-\varepsilon_{a, \theta}\right)^{2}}}$ \\
\hline $\begin{array}{c}\text { Trecho plástico } \\
\text { (III) } \\
\varepsilon>0,02\end{array}$ & $f_{y, \theta}$ & 0 \\
\hline Obs.: $\varepsilon_{y, \theta}=0,02$ & $\varepsilon_{u, \theta}=0,15$ & \\
\hline
\end{tabular}


TABELA 6.5: Fatores de redução para o aço - NBR 14323

\begin{tabular}{|c|c|c|c|}
\hline $\begin{array}{c}\text { Temperatura } \\
\text { do aço } \\
\boldsymbol{\theta}_{\mathbf{a}}\end{array}$ & $\begin{array}{c}\text { Fator de redução } \\
\text { para o limite de } \\
\text { escoamento } \\
\text { aços laminados } \\
\mathbf{a} \text { quente) } \\
\left.\mathbf{k}_{\mathbf{y}, \boldsymbol{\theta}} \mathbf{C}\right)\end{array}$ & $\begin{array}{c}\text { Fator de redução } \\
\text { para o limite de } \\
\text { escoamento } \\
\text { (aços trefilados) }\end{array}$ & $\begin{array}{c}\text { Fator de redução } \\
\text { para o módulo } \\
\text { de elasticidade } \\
\text { (todos os aços) }\end{array}$ \\
\hline 20 & 1,000 & $\mathbf{k}_{\mathbf{y o}, \boldsymbol{\theta}}$ & $\mathbf{k}_{\mathbf{E}, \boldsymbol{\theta}}$ \\
\hline 100 & 1,000 & 1,000 & 1,0000 \\
\hline 200 & 1,000 & 1,000 & 1,0000 \\
\hline 300 & 1,000 & 1,000 & 0,9000 \\
\hline 400 & 1,000 & 0,940 & 0,8000 \\
\hline 500 & 0,780 & 0,670 & 0,7000 \\
\hline 600 & 0,470 & 0,400 & 0,6000 \\
\hline 700 & 0,230 & 0,120 & 0,3100 \\
\hline 800 & 0,110 & 0,110 & 0,0900 \\
\hline 900 & 0,060 & 0,080 & 0,0675 \\
\hline 1000 & 0,040 & 0,050 & 0,0450 \\
\hline 1100 & 0,020 & 0,030 & 0,0225 \\
\hline 1200 & 0,000 & 0,000 & 0,0000 \\
\hline
\end{tabular}

Os coeficientes de redução $k_{y, \theta}, k_{y o, \theta}$ e $k_{E, \theta}$ são definidos por:

$k_{y, \theta}=\frac{f_{y, \theta}}{f_{y}} ; \quad k_{y o, \theta}=\frac{f_{y o, \theta}}{f_{y o}}$

$k_{E, \theta}=\frac{E_{\theta}}{E}$

onde

$f_{y, \theta}$ é a resistência ao escoamento dos aços laminados a quente à uma temperatura $\theta_{\mathrm{a}}$

$f_{y o, \theta}$ é a resistência ao escoamento dos aços trefilados à uma temperatura $\theta_{\mathrm{a}}$;

$f_{y}$ é a resistência ao escoamento dos aços laminados a quente a $20^{\circ} \mathrm{C}$;

$f_{y o}$ é a resistência ao escoamento dos aços trefilados a $20^{\circ} \mathrm{C}$;

$E_{\theta}$ é o módulo de elasticidade do aço à uma temperatura $\theta_{a}$;

$E$ é o módulo de elasticidade do aço a $20^{\circ} \mathrm{C}$. 
O gráfico da figura 6.5 ilustra o decréscimo da resistência ao escoamento dos aços laminados a quente e o decréscimo do módulo de elasticidade para todos os aços.

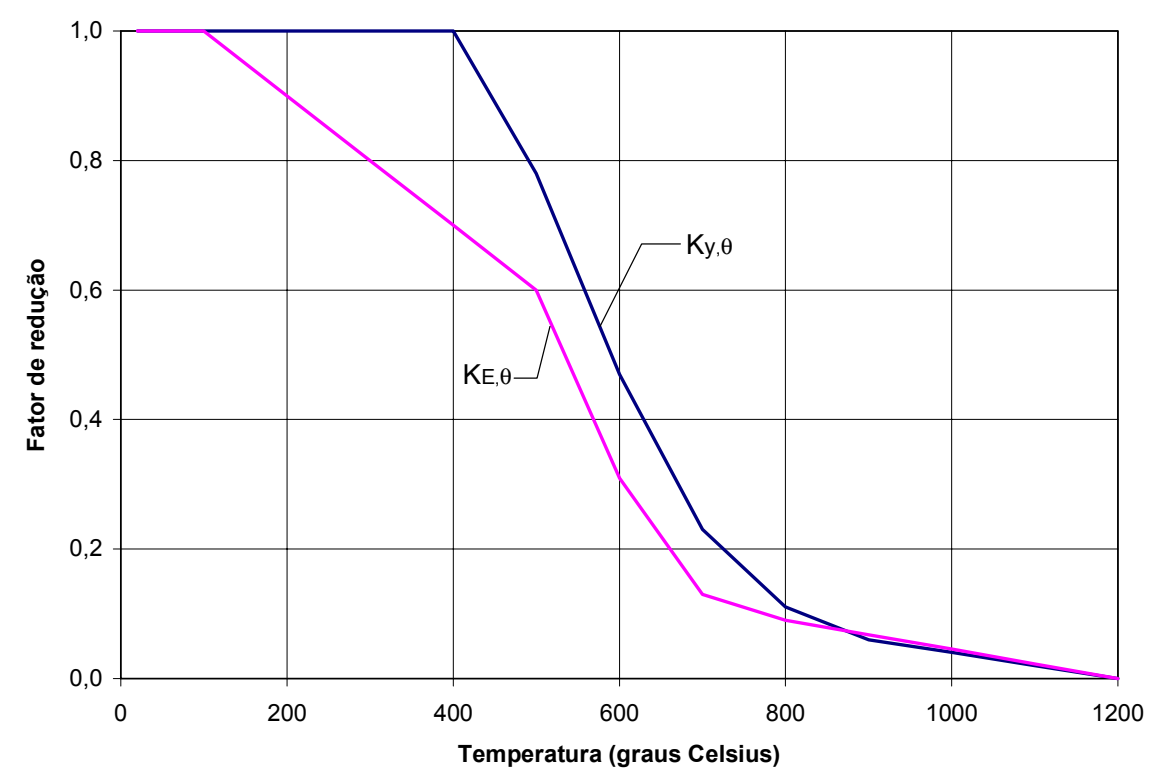

FIGURA 6.5: Variação dos fatores de redução do módulo de elasticidade e da resistência ao escoamento do aço em função da temperatura - NBR 14323

Da mesma forma que ocorre com o aço, verifica-se o decréscimo da resistência do concreto com a elevação da temperatura. A tabela 6.6 apresenta os fatores de redução da resistência característica à compressão dos concretos de densidade normal e de baixa densidade, em temperatura elevada, recomendados pelo EUROCODE 4: (1995) e pela NBR 14323. 
TABELA 6.6: Fatores de redução para o concreto - EUROCODE 4 / NBR 14323

\begin{tabular}{|c|c|c|}
\hline $\begin{array}{c}\text { Temperatura } \\
\text { do concreto } \\
\theta_{\mathbf{c}} \\
\left({ }^{\circ} \mathrm{C}\right)\end{array}$ & $\begin{array}{l}\text { Fator de redução para a } \\
\text { resistência característica } \\
\text { à compressão do concreto } \\
\text { de densidade normal } \\
\mathbf{k}_{\mathbf{c}, \boldsymbol{\theta}}\end{array}$ & $\begin{array}{l}\text { Fator de redução para a } \\
\text { resistência característica } \\
\text { à compressão do concreto } \\
\text { de baixa densidade } \\
\mathbf{k}_{\mathbf{c b}, \theta}\end{array}$ \\
\hline 20 & 1,000 & 1,000 \\
\hline 100 & 0,950 & 1,000 \\
\hline 200 & 0,900 & 1,000 \\
\hline 300 & 0,850 & 1,000 \\
\hline 400 & 0,750 & 0,880 \\
\hline 500 & 0,600 & 0,760 \\
\hline 600 & 0,450 & 0,640 \\
\hline 700 & 0,300 & 0,520 \\
\hline 800 & 0,150 & 0,400 \\
\hline 900 & 0,080 & 0,280 \\
\hline 1000 & 0,040 & 0,160 \\
\hline 1100 & 0,010 & 0,040 \\
\hline 1200 & 0,000 & 0,000 \\
\hline
\end{tabular}

Os coeficientes de redução $k_{c, \theta}$ e $k_{c b, \theta}$ são definidos por:

$$
\begin{aligned}
& k_{c, \theta}=\frac{f_{c k, \theta}}{f_{c k}} \\
& k_{c b, \theta}=\frac{f_{c k b, \theta}}{f_{c k}}
\end{aligned}
$$

onde

$f_{c k, \theta}$ é a resistência característica à compressão do concreto de densidade normal à temperatura $\theta_{c}$;

$f_{c k}$ é a resistência característica à compressão do concreto de densidade normal a 20 ${ }^{\circ} \mathrm{C}$;

$f_{c k b, \theta}$ é a resistência característica à compressão do concreto de baixa densidade à temperatura $\theta_{c}$ 
$f_{c k b, \theta}$ é a resistência característica à compressão do concreto de baixa densidade a 20 ${ }^{\circ} \mathrm{C}$.

A figura 6.6 contém uma representação gráfica do decréscimo da resistência característica à compressão do concreto com a elevação da temperatura.

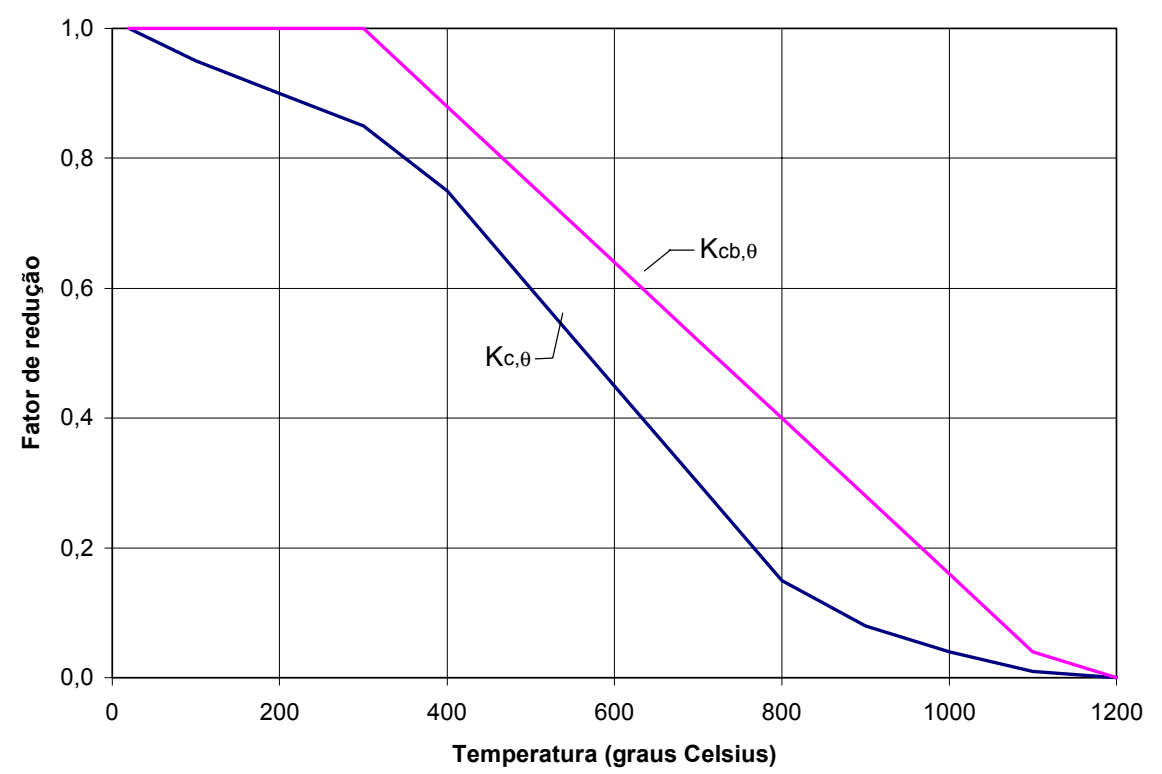

FIGURA 6.6: Variação dos fatores de redução para a resistência característica do concreto com a elevação da temperatura - EUROCODE 4 / NBR 14323

A NBR 14323 (1999) apresenta a seguinte expressão para a obtenção do módulo de elasticidade do concreto:

$E_{c, \theta}=42 \gamma_{c}^{1,5} \sqrt{k_{c, \theta} f_{c k}}$

onde

$\gamma_{c}$ é o peso específico do concreto em $\mathrm{kN} / \mathrm{m}^{3}$, não menor que $15 \mathrm{kN} / \mathrm{m}^{3}$;

$f_{c k}$ em MPa;

$k_{c, \theta}$ é dado na tabela 6.6.

A origem da expressão (6.8) é a NBR 8800, apenas modificando-se o valor de $f_{c k}$. 
SILVA (1997) cita que, para temperaturas acima de $30 \%$ da temperatura de fusão, os aços tornam-se viscosos, podendo atingir a ruína por fluência. A fluência em um elemento de aço caracteriza-se pela aumento da deformação sob carregamento e temperatura constantes. Existem muitos trabalhos realizados que visaram a comprovação experimental da fluência em aços submetidos a altas temperaturas, baseando-se na curva padrão de incêndio. SILVA (1997) ainda explica que, embora esses trabalhos indiquem a inviabilização do uso das estruturas de aço para temperaturas acima de $400{ }^{\circ} \mathrm{C}$, devido à fluência, as curvas reais tempotemperatura demonstram que a deformação por fluência tende a um valor limite, tornando viável a utilização de estruturas de aço. Não é necessária a inclusão do efeito da fluência na análise estrutural para taxas de aquecimento menores que 50 ${ }^{\circ} \mathrm{C} / \mathrm{min}$.

\subsection{DIMENSIONAMENTO DE ESTRUTURAS DE AÇO EM SITUAÇÃO DE INCÊNDIO}

Neste item serão apresentados os principais procedimentos de dimensionamento dos elementos estruturais de aço, utilizando-se os critérios da norma brasileira NBR 14323 (1999), cuja base para a elaboração foi o EUROCODE. A NBR 14323 também procurou uniformizar simbologia e terminologia entre as normas brasileiras, além de compatibilizar os procedimentos de dimensionamento com a NBR 8800 (1986) e a NBR 8681 (1984): “Ações e segurança nas estruturas”.

Segundo a NBR 14323, o dimensionamento de uma estrutura em situação de incêndio pode ser feito por meio de ensaios, ou por meio de um método simplificado de dimensionamento, ou por um método avançado de análise estrutural e térmica, ou ainda, pela combinação de ensaios e cálculos.

Neste item, será abordado o método simplificado de dimensionamento. Este método se aplica às barras prismáticas de aço constituídas por perfis laminados e soldados não-híbridos, às vigas e pilares mistos nos quais o perfil de aço utilizado é laminado ou soldado não-híbrido, e às lajes de concreto com fôrma de aço incorporada. 


\subsubsection{SOLICITAÇÕES DE CÁLCULO}

A verificação da estrutura deve ser feita pelo método dos estados limites, devendo-se proceder a combinação de ações. Para os estados limites últimos, as combinações devem ser consideradas como excepcionais, pois as ações decorrentes da elevação da temperatura em virtude do incêndio têm um tempo de atuação muito pequeno, além da baixa probabilidade de ocorrência durante a vida útil da construção. Essas combinações devem estar de acordo com a NBR 8681 (1984) e podem ser expressas por:

a) $\sum_{i=1}^{n} \gamma_{g i} F_{G i}+F_{Q, e x c}+0,2 F_{Q}$

Em locais em que não há predominância de pesos de equipamentos que permaneçam fixos por longos períodos de tempo, nem de elevadas concentrações de pessoas.

b) $\sum_{i=1}^{n} \gamma_{g i} F_{G i}+F_{Q, e x c}+0,4 F_{Q}$

Em locais em que há predominância de pesos de equipamentos que permaneçam fixos por longos períodos de tempo, ou de elevadas concentrações de pessoas.

c) $\sum_{i=1}^{n} \gamma_{g i} F_{G i}+F_{Q, e x c}+0,6 F_{Q}$

Em bibliotecas, arquivos, depósitos, oficinas e garagens.

onde

$F_{G}$ é o valor característico da ação permanente;

$F_{Q, e x c}$ é o valor característico das ações térmicas;

$F_{Q}$ é o valor característico das ações variáveis devidas às cargas acidentais;

$\gamma_{g}$ é o coeficiente de ponderação para as ações permanentes, igual a:

1,1 para ação permanente desfavorável de pequena variabilidade;

1,2 para ação permanente desfavorável de grande variabilidade;

1,0 para ação permanente favorável de pequena variabilidade; 
0,9 para ação permanente favorável de grande variabilidade;

O termo grande ou pequena variabilidade provêm da NBR 8800 e refere-se ao fato de haver controle rigoroso de peso. Na NBR 8800, são consideradas ações permanentes de pequena variabilidade apenas os pesos próprios de elementos metálicos e pré-fabricados.

A norma recomenda que, na determinação das solicitações de cálculo, as deformações de origem térmica resultantes dos gradientes térmicos sejam consideradas, a menos que se utilize como curva temperatura-tempo a curva padrão da NBR 5628, o que é a favor da segurança, evidentemente. Os efeitos das deformações térmicas axiais podem ser desprezados.

A partir de uma análise não-linear de um pórtico plano deslocável, simétrico, formado por dois pilares e uma viga ligados rigidamente entre si, submetidos a temperaturas elevadas, SILVA (1997) concluiu que:

- Quando os pilares estiverem totalmente imersos no compartimento em chamas, o aumento da temperatura, até um determinado valor, provoca um aumento dos momentos fletores nos pilares, devido à dilatação das vigas; após esse valor de temperatura, os momentos fletores decrescem, devido à redução de rigidez dos pilares. Sendo assim, a desconsideração das deformações térmicas axiais, proposto pelo método simplificado de dimensionamento, conduz a valores favoráveis à segurança.

- Se os pilares estiverem fora da ação do fogo, a redução dos momentos fletores nos pilares não ocorre. Dessa forma, o método simplificado de dimensionamento pode conduzir a resultados contra a segurança para as vigas.

\subsubsection{RESISTÊNCIA DE ELEMENTOS ESTRUTURAIS DE AÇO}

A determinação da resistência de elementos estruturais de aço em situação de incêndio pela NBR 14323 é muito semelhante à forma apresentada pela NBR 8800 
para a obtenção da resistência em temperatura ambiente, introduzindo-se apenas alguns coeficientes que levam em consideração o efeito de altas temperaturas.

Para os estados limites últimos em situação de incêndio, os coeficientes de resistência são os seguintes:

$\phi_{f i, a}=1,00$ para o aço;

$\phi_{f i, c}=1,00$ para o concreto.

Com relação à distribuição de temperatura, dependendo do tipo de solicitação e do estado limite último, considera-se simplificadamente ou uma distribuição uniforme da temperatura na seção transversal e ao longo do comprimento ou uma distribuição não-uniforme por meio de procedimentos favoráveis à segurança.

\subsubsection{RESISTÊNCIA À TRAÇÃO}

Para as barras tracionadas axialmente, com distribuição uniforme da temperatura na seção transversal e ao longo do comprimento, a resistência à tração é dada por:

$$
N_{f i, R d}=\phi_{f i, a} k_{y, \theta} A_{g} f_{y}
$$

onde

$k_{y, \theta}$ é o fator de redução da resistência ao escoamento, conforme a tabela 6.5; $A_{g}$ é a área bruta da seção transversal da barra de aço.

Não é necessária a verificação da ruptura da seção líquida como estado limite último, uma vez que a temperatura do aço será menor na ligação devido à presença do material adicional. 


\subsubsection{RESISTÊNCIA À COMPRESSÃO}

A resistência de cálculo à compressão axial de uma barra com distribuição uniforme da temperatura na seção transversal e ao longo do comprimento é calculada por:

$$
N_{f i, R d}=\phi_{f i, a} \frac{\rho_{f i} k_{y, \theta} A_{g} f_{y}}{\kappa_{a}}
$$

onde

$\rho_{f i}$ é o fator de redução da resistência à compressão em situação de incêndio. Esse parâmetro é obtido usando-se a curva de flambagem "c" da NBR 8800, independente do tipo de seção transversal, respeitando-se o eixo em que a instabilidade ocorre. $\mathrm{O}$ índice de esbeltez reduzido a ser utilizado neste caso é calculado por:

$\bar{\lambda}_{\theta}=\bar{\lambda} \sqrt{\frac{k_{y, \theta}}{k_{E, \theta}}}$

$\bar{\lambda}$ é o parâmetro de esbeltez definido na NBR 8800;

$k_{y, \theta}$ é o fator de redução da resistência ao escoamento, conforme a tabela 6.5;

$k_{E, \theta}$ é o fator de redução do módulo de elasticidade, conforme a tabela 6.5;

$\kappa_{a}$ é o fator de correção empírico da resistência da barra em temperatura elevada, assumindo os seguintes valores:

$$
\begin{array}{ll}
\kappa_{a}=1,0+\bar{\lambda}_{\theta} & \text { para } 0 \leq \bar{\lambda}_{\theta} \leq 0,2 \\
\kappa_{a}=1,2 & \text { para } \bar{\lambda}_{\theta}>0,2
\end{array}
$$

Vale notar que o índice de esbeltez reduzido $\bar{\lambda}_{\theta}$ é o mesmo índice $\bar{\lambda}$ da NBR 8800 , substituindo-se $f_{y}$ por $k_{y, \theta} f_{y}$ e $E$ por $k_{E, \theta} E$.

A aplicação da expressão (6.13) é restrita a barras cujos elementos componentes da seção transversal não possuam relações largura/espessura superiores aos valores dados na tabela 1 da NBR 8800 para seções classe 3. 


\subsubsection{RESISTENNCIA AO MOMENTO FLETOR}

O índice de esbeltez $\lambda$, correspondente aos estados limites últimos de flambagem local da mesa, flambagem local da alma e flambagem lateral com torção, deve ser calculado conforme o anexo D da NBR 8800.

Os parâmetros de esbeltez $\lambda_{p, f i}, \lambda_{r, f i}$, em situação de incêndio, que correspondem à plastificação e ao limite de proporcionalidade, respectivamente, são calculados da mesma forma à apresentada pelo anexo D da NBR 8800 para o cálculo dos parâmetros $\lambda_{p}$ e $\lambda_{r}$, devendo-se adotar os valores reduzidos de $E, f_{y}$ e $f_{r}$. A tensão residual $f_{r}$ pode ser reduzida com o fator de redução $k_{y, \theta}$.

Nos estados limites últimos de flambagem local da mesa e flambagem local da alma considera-se a distribuição não uniforme de temperatura. Por sua vez, no estado limite de flambagem lateral com torção, considera-se a distribuição uniforme de temperatura, corrigindo-se o momento resistente por um fator empírico igual a 1,2 .

Para as vigas de seção $\mathrm{T}$, a norma apresenta uma formulação à parte para o cálculo do momento fletor resistente.

A resistência ao momento fletor de uma barra fletida, exceto se a seção transversal tiver a forma de $\mathrm{T}$, é calculada por:

- Flambagem local da mesa / alma :

Se $\lambda \leq \lambda_{p, f i}$ :

$$
M_{f i, R d}=\phi_{f i, a} \kappa_{1} \kappa_{2} k_{y, \theta} M_{p l}
$$

Se $\lambda_{p, f i}<\lambda \leq \lambda_{r, f i}$ :

$$
M_{f i, R d}=\phi_{f i, a} \kappa_{1} \kappa_{2} k_{y, \theta}\left[M_{p l}-\left(M_{p l}-M_{r}\right) \frac{\lambda-\lambda_{p, f i}}{\lambda_{r, f i}-\lambda_{p, f i}}\right]
$$

- Flambagem lateral com torção 
Se $\lambda \leq \lambda_{p, f i}$ :

$$
M_{f i, R d}=\phi_{f i, a} \kappa_{1} \kappa_{2} k_{y, \theta} M_{p l}
$$

Se $\lambda_{p, f i}<\lambda \leq \lambda_{r, f i}$ :

$$
M_{f i, R d}=\phi_{f i, a} \frac{k_{y, \theta}}{1,2}\left[M_{p l}-\left(M_{p l}-M_{r}\right) \frac{\lambda-\lambda_{p, f i}}{\lambda_{r, f i}-\lambda_{p, f i}}\right]
$$

Se $\lambda>\lambda_{r, f i}$

$$
M_{f i, R d}=\phi_{f i, a} \frac{k_{E, \theta} M_{c r}}{1,2}
$$

onde

$M_{c r}$ é o momento fletor de flambagem elástica em temperatura ambiente, obtido de acordo com o anexo D da NBR 8800;

$M_{p l}$ é o momento de plastificação da seção transversal para projeto em temperatura ambiente;

$M_{r}$ é o momento fletor correspondente ao início do escoamento da seção transversal para projeto em temperatura ambiente, obtido de acordo com o anexo D da NBR 8800

$\kappa_{l}$ é um fator de correção para temperatura não-uniforme na seção transversal, apresentando os seguintes valores:

para uma viga com todos os quatro lados expostos: $\kappa_{1}=1,00$;

para uma viga com três lados expostos, com laje de concreto ou mista no quarto lado: $\kappa_{1}=1,40$;

$\kappa_{2}$ é um fator de correção para temperatura não-uniforme ao longo do comprimento da barra, assumindo os seguintes valores:

nos apoios de uma viga estaticamente indeterminada: $\kappa_{2}=1,15$;

em demais casos: $\kappa_{2}=1,00$;

1,2 é um fator de correção empírico da resistência da barra em temperatura elevada. 


\subsubsection{VERIFICAÇÃO À FLEX}

Para a verificação de elementos submetidos à flexão composta, existem duas expressões de interação momento-normal, análogas às utilizadas para barras de aço isoladas:

1) Aplicável para elementos flexo-tracionados e flexo-comprimidos:

$\frac{N_{f i, S d}}{N_{f i, R d}}+\frac{M_{x, f i, S d}}{M_{x, f i, R d}}+\frac{M_{y, f i, S d}}{M_{y, f i, R d}} \leq 1,0$

onde

$N_{f i, S d}$ é a força normal de cálculo para situação de incêndio;

$N_{f i, R d}$ é a resistência de cálculo à tração, conforme a expressão (6.12), ou resistência de cálculo à compressão, igual a $\phi_{f i, a} k_{y, \theta} A_{g} f_{y}$;

$M_{x, f i, S d}$ é o momento fletor solicitante de cálculo, em situação de incêndio, em torno do eixo $\mathrm{x}$;

$M_{y, f i, S d}$ é o momento fletor solicitante de cálculo, em situação de incêndio, em torno do eixo $y$.

$M_{x, f i, R d}$ é a resistência de cálculo ao momento fletor, em situação de incêndio, em torno do eixo $\mathrm{x}$;

$M_{y, f i, R d}$ - resistência de cálculo ao momento fletor, em situação de incêndio, em torno do eixo $y$.

2) Aplicável somente para os elementos flexo-comprimidos:

$$
\frac{N_{f i, S d}}{N_{f i, R d}}+\frac{C_{m x} M_{x, f i, S d}}{\left(1-\frac{N_{f i, S d}}{N_{f i, e x}}\right) M_{x, f i, R d}}+\frac{C_{m y} M_{y, f i, S d}}{\left(1-\frac{N_{f i, S d}}{N_{f i, e y}}\right) M_{y, f i, R d}} \leq 1,0
$$

onde 
$C_{m x}, C_{m y}$ são fatores de equivalência de carregamento, definidos no item 5.6 da NBR 8800 ;

$N_{f i, e x}, N_{f i, e y}$ são as forças normais de flambagem elástica, em situação de incêndio, em torno dos eixos x e y, respectivamente. Para cada um dos eixos, tem-se:

$$
N_{f i, e}=\frac{A_{g} k_{y, \theta} f_{y}}{\left(\bar{\lambda}_{\theta}\right)^{2}}
$$

Pode-se notar a ausência do fator 0,73 na expressão (6.20), porém, ainda presente na expressão de interação da NBR 8800. Este fator deverá ser excluído na nova revisão da NBR 8800. 


\subsection{INCÊNDIO EM ESTRUTURAS MISTAS}

\subsubsection{VIGAS MISTAS}

Em vigas mistas submetidas a elevadas temperaturas decorrentes de incêndio, observa-se que a temperatura da mesa inferior da viga de aço atinge valores consideravelmente maiores que a mesa superior conectada à laje de concreto, admitindo-se um mesmo nível de proteção térmica em toda a seção de aço. Na laje de concreto, a temperatura varia bruscamente entre a face da laje exposta ao fogo e a face não exposta, existindo, portanto, um elevado gradiente de temperatura ao longo da espessura da laje. A figura 6.7 ilustra a variação de temperatura na seção mista.
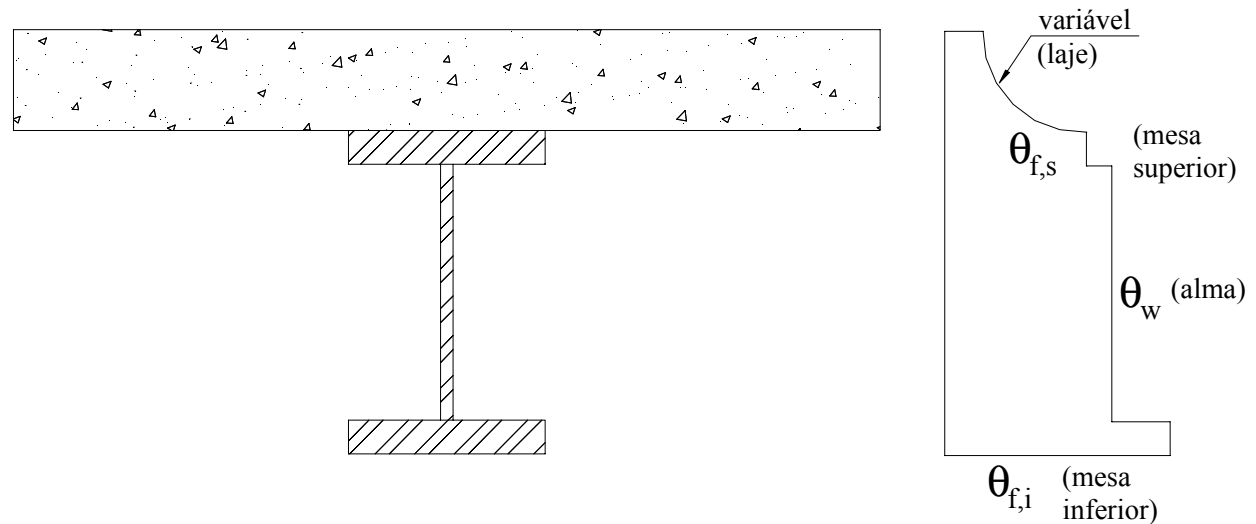

FIGURA 6.7: Variação da temperatura ao longo da seção de vigas mistas EUROCODE 4: Parte 1.2 (1995)

O EUROCODE 4 e a NBR 14323 adotam uma variação da temperatura ao longo da altura da laje de concreto, de acordo com a tabela 6.7. Admite-se uma distribuição de temperatura constante ao longo da largura efetiva da laje de concreto. 
TABELA 6.7: Variação de temperatura na altura das lajes de concreto

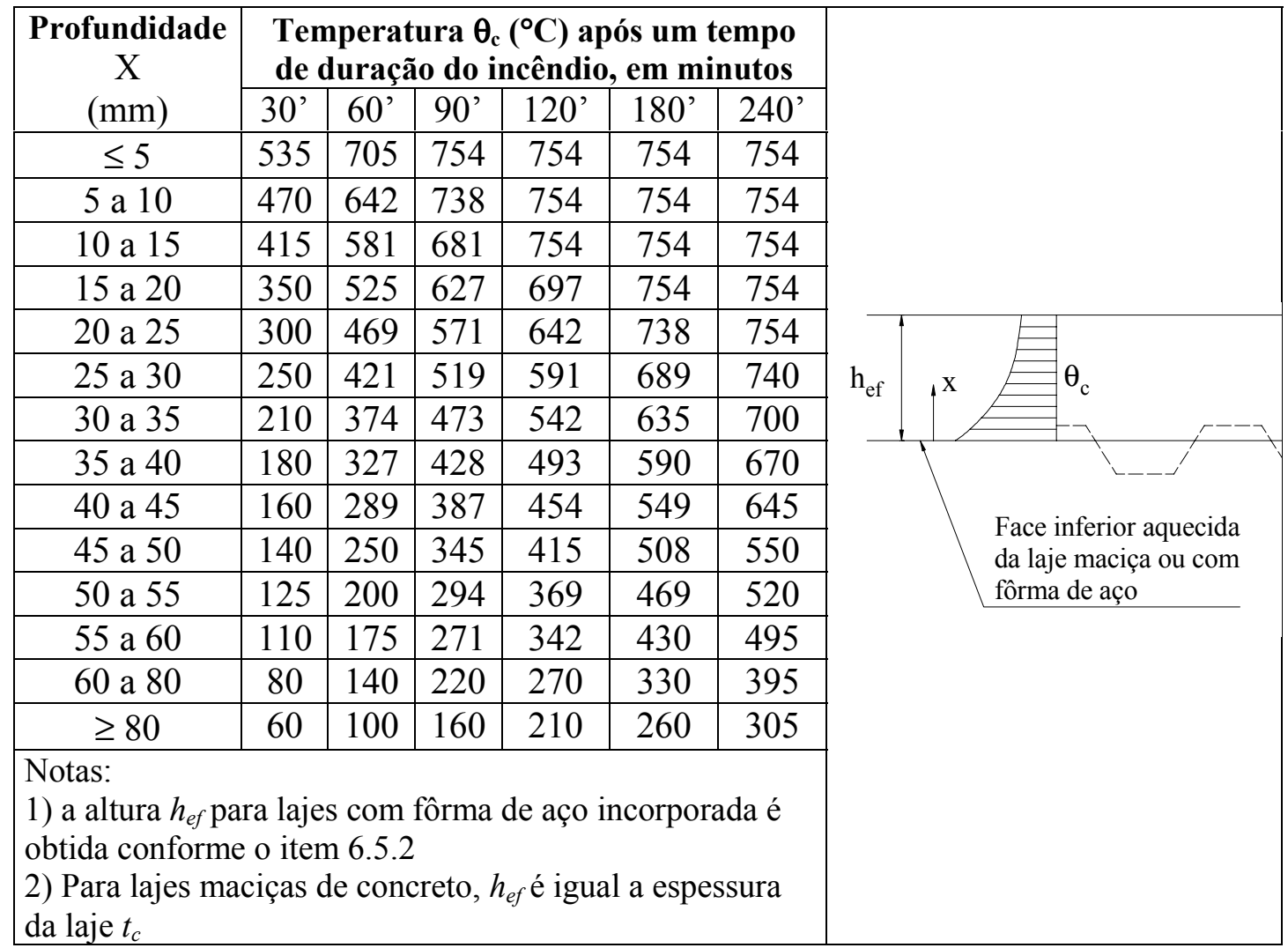

A tabela 6.7 é aplicável às lajes de concreto de densidade normal, maciças ou com fôrma de aço incorporada, desde que os critérios de isolamento térmico das normas sejam respeitados.

KRUPPA \& ZHAO (1995) fizeram algumas observações com relação ao comportamento de vigas mistas em situação de incêndio. Entre elas, citam o tipo de colapso, que pode ocorrer devido aos seguintes fatores:

- Existência de um grande deslocamento vertical da viga;

- Ruptura da ligação (conectores), especialmente no caso de conexão parcial;

- Esmagamento do concreto na zona comprimida da laje, em especial quando a viga de aço é protegida, pois as deformações na laje serão maiores que as deformações na seção de aço.

Fizeram ainda outras observações, a saber: 
- Em situação de incêndio, a temperatura do concreto na face exposta ao fogo não é significativamente afetada pela espessura da laje;

- A temperatura ao longo da alma é aproximadamente a média das temperaturas das mesas superior e inferior;

- A resistência à compressão do concreto e a largura da laje exercem pequena influência na resistência da seção mista ao fogo, pois, estando a viga de aço a elevadas temperaturas, requer-se uma zona comprimida de laje de concreto menor para o equilíbrio de forças. Também concluíram que o momento fletor resistente em situação de incêndio é proporcional à resistência ao escoamento do aço.

\section{Conectores de cisalhamento}

$\mathrm{O}$ aumento da temperatura cria um esforço de cisalhamento adicional nos conectores, devido às diferentes deformações térmicas entre os materiais aço e concreto.

De acordo com KRUPPA \& ZHAO (1995), o comportamento estrutural dos conectores de cisalhamento pode ser melhor avaliado por meio de ensaios do tipo push out sob elevadas temperaturas, obtendo-se então o diagrama forçaescorregamento da figura 6.8.

Para efeito de obtenção da resistência nominal de conectores de cisalhamento, o EUROCODE 4 assume que o conector e a laje de concreto atingem $80 \%$ e $40 \%$ da temperatura da mesa superior da viga de aço, respectivamente. Logo, os fatores de redução das propriedades mecânicas do aço e do concreto devem ser obtidos a partir dessas temperaturas. Esse procedimento também é adotado pela NBR 14323. Embora as expressões para a determinação da resistência nominal dos conectores do EUROCODE 4 e da NBR 14323 não sejam as mesmas, os fatores de redução podem ser utilizados para obter a resistência dos conectores a elevadas temperaturas. 


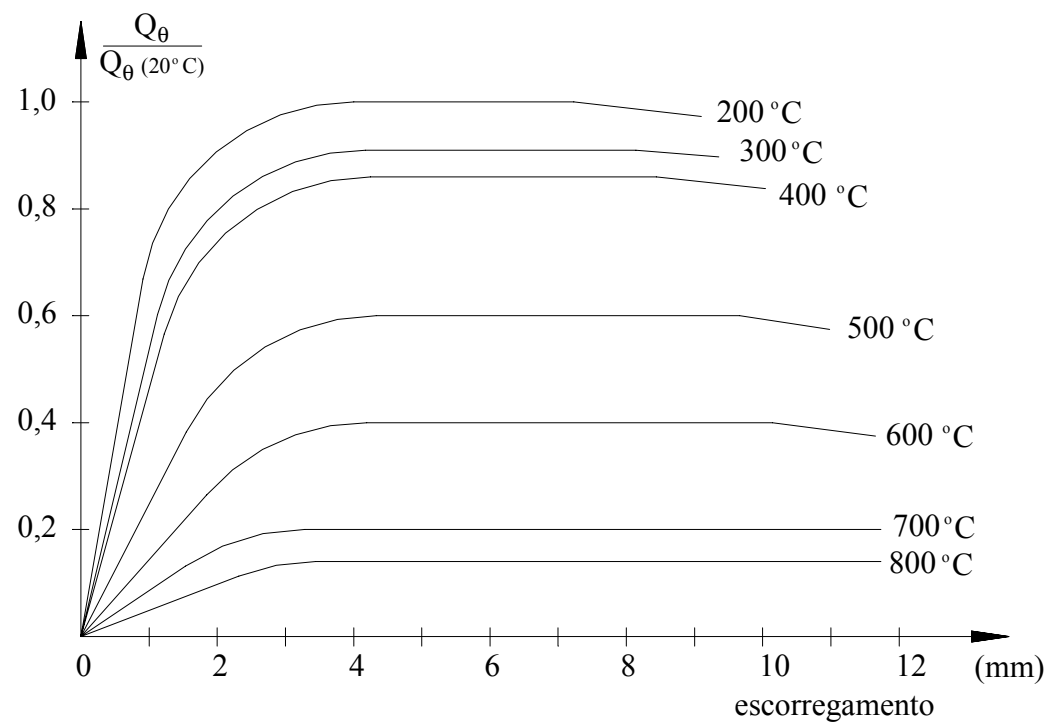

FIGURA 6.8: Diagrama força-escorregamento de conectores em temperatura elevada

Na figura 6.8, $Q_{\theta}$ é a resistência da ligação para a temperatura $\theta$, e $Q_{\theta, 20^{\circ} \mathrm{C}}$ é a resistência da ligação a temperatura de $20^{\circ} \mathrm{C}$.

\section{DIMENSIONAMENTO DE VIGAS MISTAS}

O dimensionamento de vigas mistas em situação de incêndio é abordado pelo anexo A da norma brasileira NBR 14323 (1999), através de um método simplificado, o qual encontra base no EUROCODE 4: Parte1.2 (1995). Este método simplificado é aplicável a vigas mistas cujo perfil de aço é do tipo "I" , devendo-se atender às seguintes condições:

- Relação largura/espessura da alma: $\frac{h_{w}}{t_{w}} \leq 3,5 \sqrt{\frac{E}{f_{y}}}$ (elemento compacto)

- Relação largura/espessura da mesa comprimida: $\lambda \leq \lambda_{r}$

onde $\lambda$ e $\lambda_{r}$ são obtidos a partir do anexo D da NBR 8800 para o estado limite último de flambagem local da mesa:

$$
\lambda=\frac{b_{f}}{2 t_{f}}
$$


$\lambda_{r}=0,62 \sqrt{\frac{E W_{c}}{M_{r}}}$ para perfis soldados e

$\lambda_{r}=0,82 \sqrt{\frac{E W_{c}}{M_{r}}}$ para perfis laminados

onde

$W_{c}$ é o módulo resistente elástico do lado comprimido da seção, relativo ao eixo de flexão;

$W_{t}$ é o módulo resistente elástico do lado tracionado da seção, relativo ao eixo de flexão;

$M_{r}$ é o menor valor entre $\left(f_{y}-f_{r}\right) W_{c}$ e $f_{y} W_{t}$;

$f_{r}$ é a tensão residual, admitida igual a $115 \mathrm{MPa}$.

Em vigas mistas, admite-se uma distribuição não-uniforme da temperatura, devendo-se dividir a seção transversal em três partes: mesa inferior, mesa superior e alma. Deve-se obter a temperatura para cada um desses três elementos, a partir de expressões fornecidas pela norma referentes à elevação da temperatura do aço. Essas expressões são função do fator de massividade, das propriedades térmicas do aço e da existência ou não de proteção contra incêndio.

\section{Resistência ao momento fletor positivo:}

Em linhas gerais, a determinação da resistência de vigas mistas em regiões de momento fletor positivo é feita seguindo os procedimentos de redução da resistência das propriedades mecânicas dos materiais aço e concreto, conforme o item 6.3. O dimensionamento de vigas mistas em situação de incêndio é análogo ao apresentado para a temperatura ambiente, abordado pela norma NBR 8800 .

O valor do momento resistente de cálculo é dado por:

$M_{f i, R d}=\phi_{f i, a} M_{f i, n}$

onde 
$\phi_{f i, a}$ é o coeficiente de resistência, igual a 1,0 ;

$M_{f i, n}$ é a resistência nominal ao momento fletor.

De maneira simplificada, a norma permite que se considere uma temperatura uniforme ao longo da espessura da laje de concreto. O valor dessa temperatura é dado por:

$\theta_{c}=\frac{1}{h_{e f}} \sum_{j=1}^{n} \theta_{c, j} e_{j}$

onde

$h_{e f}$ é a espessura efetiva da laje, de acordo com a expressão (6.39);

$n$ é o número de trechos em que a laje foi dividida, ao longo da espessura;

$\theta_{c, j}$ é a temperatura do trecho $\mathrm{j}$;

$e_{j}$ é a espessura de cada trecho.

Com o procedimento de temperatura uniforme da laje, a resistência nominal ao momento fletor $M_{f i, n}$ pode ser calculada de acordo com os tópicos a, b e c seguintes:

a) Interação completa e linha neutra plástica na laje de concreto (figura 6.9)

Ocorre se:

$Q_{f i, n} \geq\left(A f_{y}\right)_{f i, a}$ e $0,85 k_{c, \theta} f_{c k} b t_{c} \geq\left(A f_{y}\right)_{f i, a}$

com

$\left(A f_{y}\right)_{f i, a}=\left[k_{y, \theta i}\left(b_{f i} t_{f i}+h_{w} t_{w}\right)+k_{y, \theta s}\left(b_{f s} t_{f s}\right)\right] f_{y}$

onde $k_{y, \theta i}$ e $k_{y, \theta s}$ são os fatores de redução da resistência ao escoamento do aço em função das temperaturas da mesa inferior e superior, $\theta_{i}$ e $\theta_{s}$, respectivamente.

Neste caso, tem-se que: 
$T_{f i}=\left(A f_{y}\right)_{f i, a}$

$C_{f i}=0,85 k_{c, \theta} f_{c k} b a$

$C_{f i}=T_{f i} \quad$ (condição de equilíbrio)

$a=\frac{\left(A f_{y}\right)_{f i, a}}{0,85 k_{c, \theta} f_{c k} b} \leq t_{c}$

$M_{f i, n}=k_{y, \theta i} f_{y}\left[\left(b_{f i} t_{f i}\right)\left(d+h_{F}+t_{c}+\frac{t_{f i}+a}{2}\right)+\left(h_{w} t_{w}\right)\left(t_{f s}+h_{F}+t_{c}+\frac{h-a}{2}\right)\right]+$

$+k_{y, \theta s} f_{y}\left(b_{f s} t_{f s}\right)\left(h_{F}+t_{c}+\frac{t_{f s}-a}{2}\right)$

b) Interação completa e linha neutra plástica na viga de aço (figura 6.9)

Ocorre se:

$Q_{f i, n} \geq C_{f i}$ e $\left(A f_{y}\right)_{f i, a} \geq 0,85 k_{c, \theta} f_{c k} b t_{c}$

com

$C_{f i}=0,85 k_{c, \theta} f_{c k} b t_{c}$

$\left(A f_{y}\right)_{f i, a}=\left[k_{y, \theta i}\left(b_{f i} t_{f i}+h_{w} t_{w}\right)+k_{y, \theta s}\left(b_{f s} t_{f s}\right)\right] f_{y}$

As resultantes de compressão $C_{f i}^{\prime}$ e de tração $T_{f i}$ na viga de aço são relacionadas pela condição de equilíbrio:

$T_{f i}=C_{f i}+C_{f i}^{\prime}$

A posição da linha neutra da seção plastificada, medida a partir do topo da viga de aço $\left(y_{p}\right)$, e a resistência nominal ao momento fletor $M_{f i, n}$, podem ser assim determinadas:

- Se $C_{f i}+k_{y, \theta s}\left(b_{f s} t_{f s}\right) f_{y}>k_{y, \theta i}\left(b_{f i} t_{f i}+h_{w} t_{w}\right) f_{y}$, então a linha neutra situar-se-á na mesa superior, e 
$y_{p}=0,5 \frac{\left(A f_{y}\right)_{f i, a}-C_{f i}}{k_{y, \theta s} b_{f s} f_{y}}$

$$
\begin{aligned}
& M_{f i, n}=C_{f i}\left(y_{p}+h_{F}-\frac{y_{c}}{2}\right)+k_{y, \theta s} f_{y} b_{f s}\left[\frac{y_{p}^{2}+\left(t_{f s}-y_{p}\right)^{2}}{2}\right]+ \\
& +k_{y, \theta i} f_{y}\left[\left(b_{f i} t_{f i}\right)\left(d-\frac{t_{f i}}{2}-y_{p}\right)+\left(h_{w} t_{w}\right)\left(\frac{h_{w}}{2}+t_{f s}-y_{p}\right)\right]
\end{aligned}
$$

com

$y_{c}=t_{c}$

- Se $C_{f i}+k_{y, \theta s}\left(b_{f s} t_{f s}\right) f_{y}<k_{y, \theta i}\left(b_{f i} t_{f i}+h_{w} t_{w}\right) f_{y}$, então a linha neutra situar-se-á na alma, e

$$
\begin{aligned}
& y_{p}=0,5 \frac{\left\lfloor k_{y, \theta i}\left(b_{f i} t_{f i}+h_{w} t_{w}+2 t_{f s} t_{w}\right)-k_{y, \theta s} b_{f s} t_{f s}\right\rfloor f_{y}-C_{f i}}{k_{y, \theta i} t_{w} f_{y}} \\
& M_{f i, n}=C_{f i}\left(y_{p}+h_{F}-\frac{y_{c}}{2}\right)+k_{y, \theta s} f_{y} b_{f s} t_{f s}\left(y_{p}-\frac{t_{f s}}{2}\right)+ \\
& +k_{y, \theta i} f_{y}\left[t_{w} \frac{\left(y_{p}-t_{f s}\right)^{2}+\left(h_{w}-y_{p}+t_{f s}\right)^{2}}{2}+b_{f i} t_{f i}\left(d-\frac{t_{f i}}{2}-y_{p}\right)\right]
\end{aligned}
$$

com

$y_{c}=t_{c}$ 


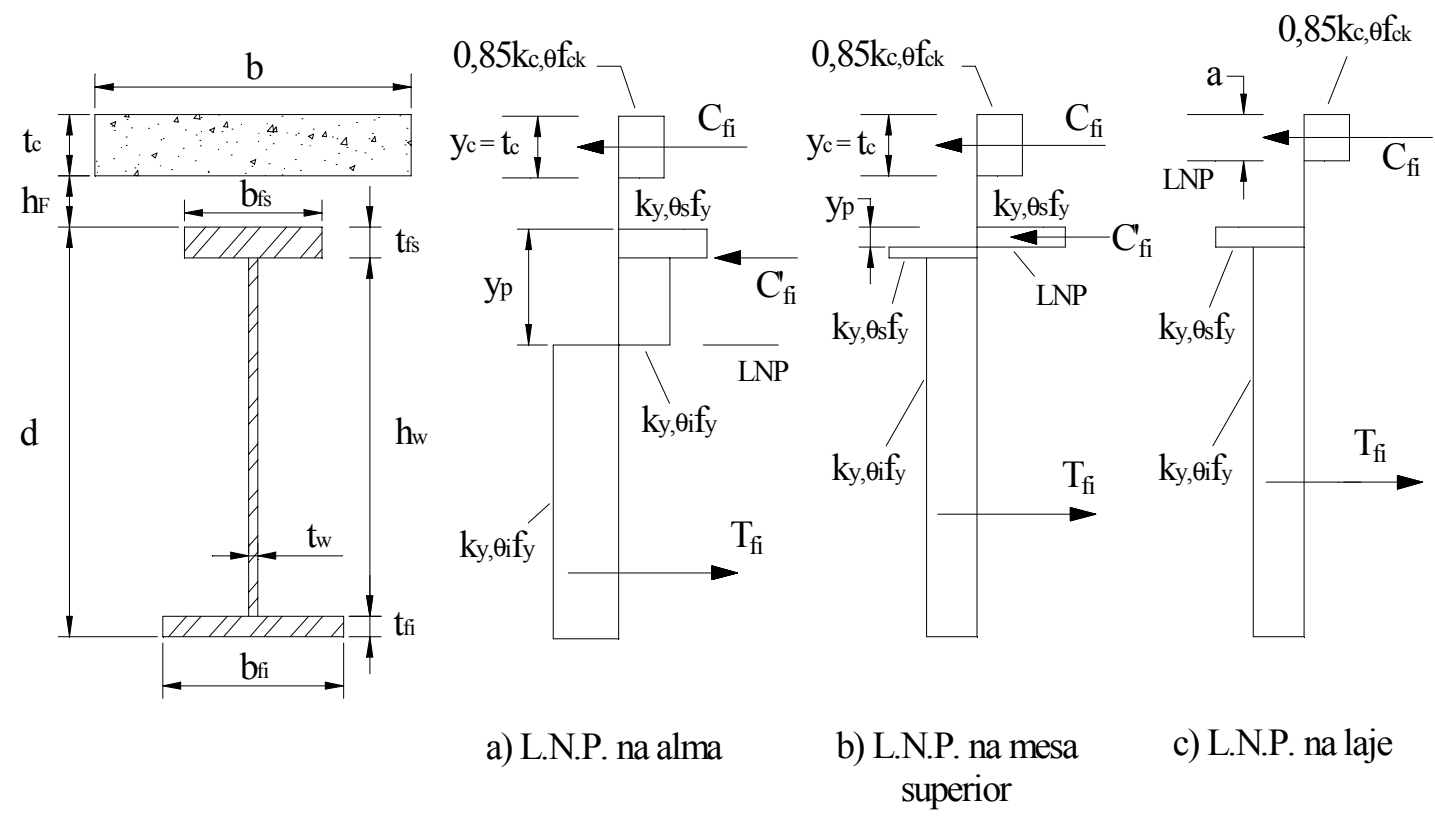

FIGURA 6.9: Tensões na seção mista em temperatura elevada - interação completa

c) Interação parcial (figura 6.10)

Ocorre se:

$Q_{f i, n}<0,85 k_{c, \theta} f_{c k} b t_{c} \quad$ e $\quad Q_{f i, n}<\left(A f_{y}\right)_{f i, a}$, porém $Q_{f i, n}$ não deve ser menor que a metade desses dois valores, com

$\left(A f_{y}\right)_{f i, a}=\left[k_{y, \theta i}\left(b_{f i} t_{f i}+h_{w} t_{w}\right)+k_{y \theta s}\left(b_{f s} t_{f s}\right)\right] f_{y}$

Cumpridas estas condições, tem-se:

$C_{f i}=Q_{f i, n} \quad$ (condição de equilíbrio)

A determinação da posição da linha neutra da seção plastificada $\left(y_{p}\right)$ é feita com as expressões (6.32) ou (6.34). Para determinação da resistência nominal ao momento fletor $M_{f i, n}$, são válidas também as expressões (6.33) ou (6.35), com o novo valor de $C_{f i}$, e com

$y_{c}=a$

sendo 
$a=\frac{C_{f i}}{0,85 k_{c, \theta} f_{c k} b}$

As grandezas geométricas e demais termos das expressões (6.24) à (6.38) são os seguintes:

$b$ é a largura efetiva da laje;

$b_{f i}$ é a largura da mesa inferior do perfil de aço;

$t_{f i}$ é a espessura da mesa inferior do perfil de aço;

$b_{f s}$ é a largura da mesa superior do perfil de aço;

$t_{f s}$ é a espessura da mesa superior do perfil de aço;

$a$ é a espessura comprimida da laje ou, para interação parcial, espessura considerada efetiva;

$f_{c k}$ é a resistência característica do concreto à compressão;

$Q_{f i, n}$ é o somatório das resistências individuais em situação de incêndio $q_{f i, t, n}$ dos conectores de cisalhamento situados entre a seção de momento máximo e a seção adjacente de momento nulo;

$h_{f}$ é a altura das nervuras da fôrma de aço;

$y_{p}$ é a distância da linha neutra da seção plastificada até a face superior da viga de aço;

$k_{c, \theta}$ é o fator de redução da resistência característica do concreto à compressão em temperatura elevada, para a temperatura atingida pela laje de concreto;

$k_{y, \theta}$ é o fator de redução da resistência ao escoamento do aço em temperatura elevada. 


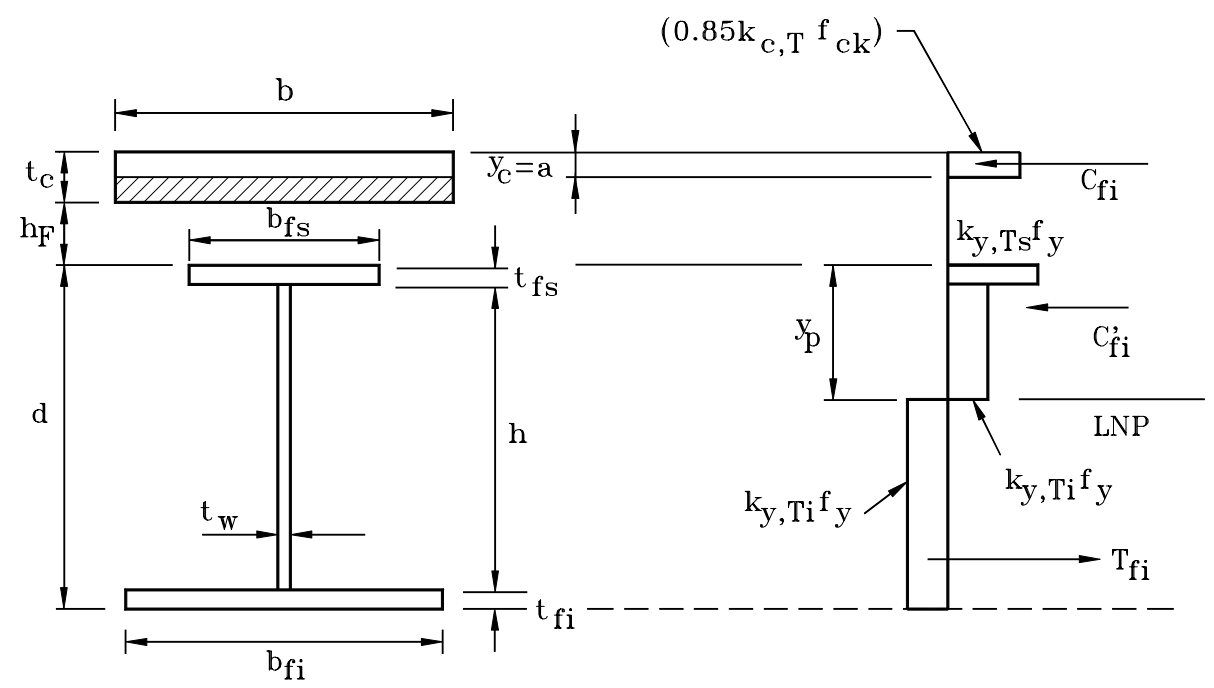

FIGURA 6.10: Tensões na seção mista em temperatura elevada-interação parcial

\subsubsection{LAJES MISTAS}

Durante a exposição ao fogo, o calor é transferido a partir da face inferior da laje. Quando a laje não é revestida por algum elemento de proteção contra o fogo, ocorre uma elevação rápida da temperatura da fôrma de aço.

HAMERLINK \& TWILT (1995) apresentam a curva tempo-temperatura para pontos notáveis da seção transversal de uma laje mista, conforme a figura 6.11. O aumento da temperatura da armadura positiva, localizada entre os pontos 3 e 5 da figura 6.11, é menor que o da fôrma de aço, fator que torna a armadura positiva importante para a resistência da laje em situação de incêndio. $O$ aumento da temperatura da armadura de distribuição (pontos 4 e 5) e da face não exposta ao fogo (pontos 6 e 7) é relativamente baixo. 


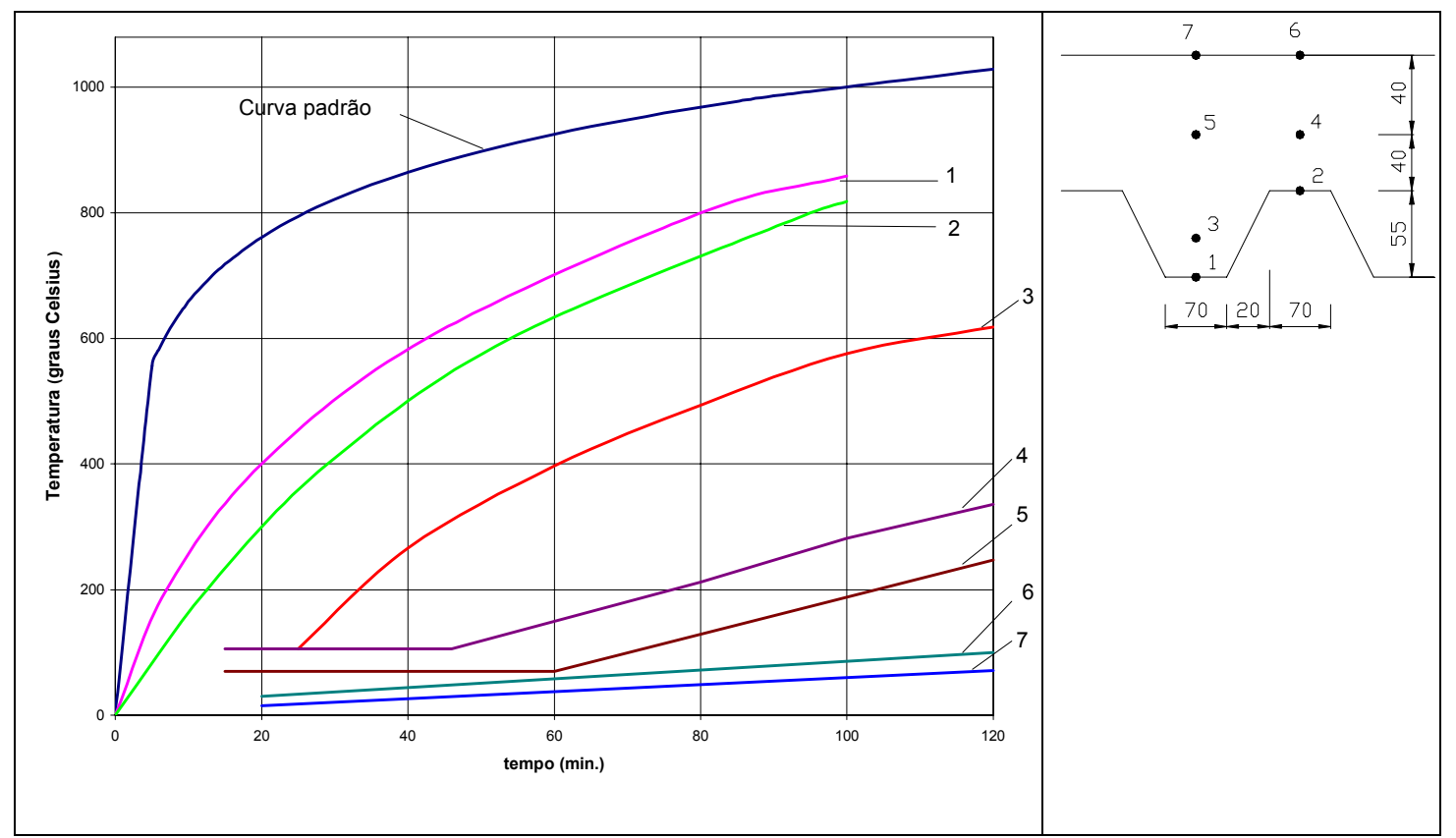

FIGURA 6.11: Curva temperatura-tempo para alguns pontos da seção transversal de laje mista - HAMERLINK (1995)

HAMERLINK \& TWILT (1995) citam que a transmissão de calor em lajes mistas é essencialmente bidimensional, e os parâmetros que mais afetam o comportamento térmico são a geometria da fôrma de aço, o peso próprio do concreto e a espessura de concreto da laje.

O modo de colapso por flexão é o mais comum em lajes mistas expostas ao fogo. Como ocorre nas vigas mistas, o aumento da temperatura provoca um decréscimo das resistências do aço e do concreto, além de reduzir a rigidez à flexão da laje.

Em lajes mistas simplesmente apoiadas, há uma importante comparação a ser feita entre lajes mistas sem armadura positiva e lajes mistas providas de armadura positiva. Na laje armada, as forças de tração são transferidas para armadura positiva, elemento que se encontra a uma temperatura inferior à fôrma de aço, conduzindo a uma resistência ao momento fletor significativamente maior em relação à laje mista não armada. O momento resistente da laje depende, portanto, da taxa de armadura longitudinal e da posição dessa armadura (recobrimento). A posição da armadura determina não somente sua temperatura mas também o braço de alavanca entre as resultantes de tração e de compressão. 
Em lajes mistas contínuas, ocorre uma redistribuição de momentos fletores em virtude da redução de rigidez e de resistência da laje. Essa redistribuição ocorre também devido à curvatura de origem térmica, causada pela distribuição nãouniforme da temperatura na seção.

\section{DIMENSIONAMENTO DE LAJES MISTAS}

O anexo C da norma brasileira NBR 14323 (1999) aborda o dimensionamento de lajes mistas em situação de incêndio, apresentando um modelo simplificado aplicável a lajes apoiadas na direção perpendicular às nervuras. Esse método baseiase nas recomendações do EUROCODE 4: Parte 1.2 (1995).

\section{Lajes sem proteção térmica}

Para as lajes desprovidas de material de proteção térmica, devem ser atendidos dois critérios: o critério de isolamento térmico e o critério de resistência frente aos carregamentos aplicados.

No critério de isolamento térmico, há uma relação entre a mínima espessura efetiva da laje com o tempo requerido de resistência ao fogo. Requer-se das lajes, com ou sem armadura adicional, uma resistência mínima ao fogo de 30 minutos, respeitando-se o critério de isolamento térmico, o qual é atendido se a espessura efetiva da laje não for menor que os valores da tabela 6.8. Quando o concreto for de baixa densidade, os valores fornecidos nessa tabela podem ser reduzidos em 10\%.

TABELA 6.8: Espessura efetiva mínima da laje mista sem proteção térmica

\begin{tabular}{|c|c|}
\hline $\begin{array}{c}\text { Tempo requerido de } \\
\text { resistência ao fogo } \\
(\mathbf{m i n})\end{array}$ & $\begin{array}{c}\text { Espessura efetiva mínima } \\
\boldsymbol{h}_{\boldsymbol{e f}} \\
(\mathbf{m m})\end{array}$ \\
\hline 30 & 60 \\
\hline 60 & 80 \\
\hline 90 & 100 \\
\hline 120 & 120 \\
\hline
\end{tabular}


A espessura efetiva da laje $h_{e f}$ é calculada de acordo com a seguinte expressão:

$h_{e f}=h_{1}+\frac{h_{2}}{2} \frac{\left(l_{1}+l_{2}\right)}{\left(l_{1}+l_{3}\right)}$

onde as dimensões $h_{1}, h_{2}, l_{1}, l_{2}$ e $l_{3}$ referem-se à seção transversal da laje, indicadas na figura 6.12. Se $l_{3}>2 l_{1}$, então a espessura efetiva deve ser tomada igual a $h_{1}$.

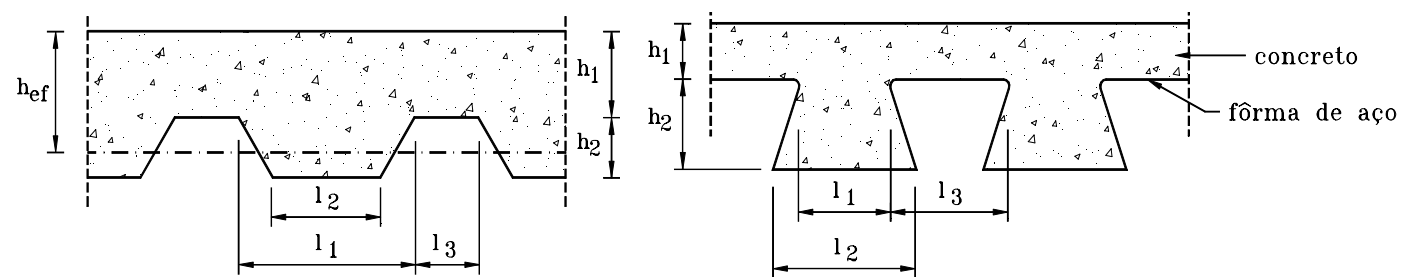

FIGURA 6.12: Dimensões da seção transversal da laje mista

No critério de resistência ao carregamento, a capacidade da laje mista à flexão é calculada com base na análise plástica global. A resistência à tração do concreto e a resistência da fôrma de aço são desprezadas no dimensionamento.

$\mathrm{Na}$ determinação da resistência ao momento fletor positivo, a influência da temperatura sobre a zona comprimida do concreto é ignorada, devendo-se tomar a resistência à compressão do concreto à temperatura ambiente. A temperatura da armadura $\theta_{s}$ é expressa em função da posição que ela ocupa na laje, por meio do seguinte parâmetro:

$\frac{1}{z}=\frac{1}{\sqrt{u_{1}}}+\frac{1}{\sqrt{u_{2}}}+\frac{1}{\sqrt{u_{3}}}$

onde

$z$ é o parâmetro utilizado para a determinação da temperatura da armadura, em $\mathrm{mm}^{1 / 2}$, conforme a tabela 6.9 ;

$u_{1}, u_{2}$ e $u_{3}$ são as distâncias (em mm) da armadura em relação à forma de aço, conforme a figura 6.13 . 


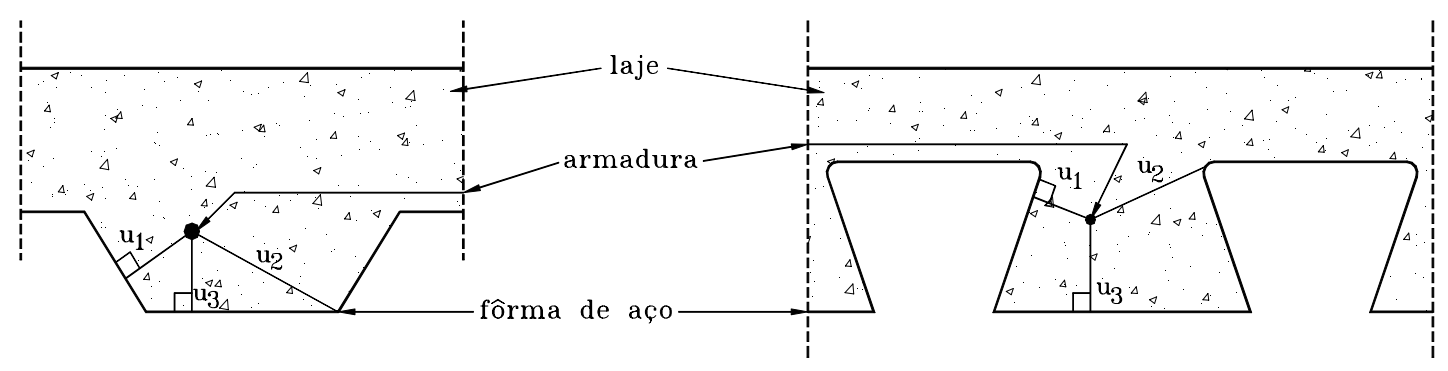

FIGURA 6.13: Posição da armadura na laje mista

TABELA 6.9: Temperatura da armadura na laje mista

\begin{tabular}{|c|c|}
\hline $\begin{array}{c}\text { Tempo requerido de } \\
\text { resistência ao fogo } \\
\text { (min) }\end{array}$ & $\begin{array}{c}\text { Temperatura } \\
\text { da armadura } \\
\left({ }^{\circ} \mathbf{C}\right)\end{array}$ \\
\hline 60 & $\theta_{s}=1175-350 z$, porém $\theta_{s} \leq 810^{\circ} \mathrm{C}$, para $z \leq 3,3 \mathrm{~mm}^{1 / 2}$ \\
\hline 90 & $\theta_{s}=1285-350 z$, porém $\theta_{s} \leq 880^{\circ} \mathrm{C}$, para $z \leq 3,6 \mathrm{~mm}^{1 / 2}$ \\
\hline 120 & $\theta_{s}=1370-350 z$, porém $\theta_{s} \leq 930^{\circ} \mathrm{C}$, para $z \leq 3,8 \mathrm{~mm}^{1 / 2}$ \\
\hline
\end{tabular}

Uma vez obtida a temperatura da armadura, pode-se calcular a resistência da armadura com os fatores de redução da resistência ao escoamento dos aços trefilados, dados na tabela 6.5 .

$\mathrm{Na}$ determinação da resistência ao momento fletor negativo, a laje pode ser analisada considerando a redução da resistência do concreto da parte inferior da laje, devido à influência da temperatura. A temperatura do concreto na zona comprimida é função da distância $X$ acima da parte inferior da laje, conforme a tabela 6.7. Por integração através da espessura da laje, a resultante de compressão no concreto pode ser igualada à resultante de tração da armadura, obtendo-se a resistência ao momento fletor negativo. Neste caso, visto que a armadura se encontra no lado não exposto ao fogo, permite-se considerá-la a temperatura ambiente.

\section{Lajes com proteção térmica}


A NBR 14323 recomenda que a espessura mínima necessária para se garantir o critério de isolamento térmico poderá ser reduzida de uma espessura equivalente em concreto do material de proteção, calculada em função da condutividade térmica. Além disso, a norma considera atendido o critério de resistência ao carregamento caso a temperatura da fôrma de aço não ultrapasse $350^{\circ} \mathrm{C}$.

A NBR 14323 cita alguns meios de proteção térmica que podem ser usados com o objetivo de diminuir a transferência de calor para a laje, a saber:

- pulverização de fibras na face inferior da laje;

- colocação de forros suspensos.

\subsubsection{PILARES MISTOS}

Sob o ponto de vista de comportamento em situação de incêndio, os pilares mistos totalmente revestidos apresentam vantagens sobre os pilares mistos preenchidos, pois o revestimento de concreto desempenha o papel de elemento de proteção ao fogo. Já os pilares mistos preenchidos requerem um estudo mais cuidadoso, pois, embora o elemento de aço não esteja protegido externamente, a presença do concreto traz melhoras relevantes no comportamento do pilar a elevadas temperaturas.

\section{Pilares mistos preenchidos}

No início da exposição ao fogo, a seção mista é responsável por resistir a todo o carregamento original. Com o aumento da temperatura, o carregamento aplicado vai sendo transferido para o concreto, até que o núcleo de concreto seja responsável por toda a resistência do pilar. Isto ocorre porque a perda de resistência do concreto ocorre de maneira mais lenta que a do aço, explicado pela baixa condutividade térmica do concreto.

A resistência de um pilar misto preenchido depende de uma série de parâmetros, tais como: dimensões e forma da seção transversal; comprimento efetivo de flambagem; intensidade do carregamento aplicado; resistência do concreto à 
compressão; utilização ou não de armadura longitudinal; tipo de agregado no concreto.

Diversas pesquisas têm sido realizadas sobre pilares preenchidos submetidos a elevadas temperaturas. LIE \& KODUR (1996) realizaram um estudo sobre os diversos parâmetros que influenciam a resistência de pilares preenchidos providos de armadura longitudinal. Com base em modelos matemáticos, concluíram que os fatores que mais afetam a resistência de pilares mistos preenchidos providos de armadura longitudinal são o diâmetro externo (ou a largura) do perfil de aço, o comprimento efetivo de flambagem, a força normal atuante no pilar e a resistência à compressão do concreto. A influência do tipo de agregado, da taxa de armadura longitudinal e do recobrimento exercem uma influência moderada. Por fim, a espessura da parede do tubo de aço, que exerce uma influência pouco significativa.

Com relação aos tipos de seções utilizadas em pilares preenchidos, LIE \& STRINGER (1994) citam que existe uma eficiência maior dos pilares preenchidos circulares em relação aos de seções quadradas, em situação de incêndio. Dentre as razões mencionadas, está o fato de a parede dos tubos quadrados de aço estar mais propensa à flambagem local que a parede dos tubos circulares. Além disso, devido à forma das seções quadradas, desenvolve-se nessas uma distribuição não-uniforme da temperatura durante o incêndio, produzindo maiores deformações no concreto quando comparadas às produzidas em seções circulares. KODUR (1999) ressalta que, para uma mesma área de seção transversal, a resistência ao fogo de pilares preenchidos circulares é maior que a dos pilares de seção quadrada.

A presença de armadura é outro fator relevante em situação de incêndio. A respeito disso, LIE \& KODUR (1996) citam que a utilização de armadura longitudinal em pilares preenchidos representa uma solução eficiente do ponto de vista estrutural, permitindo ao pilar alcançar maior resistência ao fogo.

\section{DIMENSIONAMENTO DE PILARES MISTOS}

Conforme o anexo D da norma brasileira NBR 14323, o dimensionamento de pilares mistos expostos ao fogo em todo o seu comprimento é feito utilizando-se um 
método tabular. As hipóteses adotadas para a elaboração das tabelas foram as seguintes:

a) o incêndio é limitado a somente um pavimento;

b) as barras estão submetidas a temperatura uniforme ao longo do comprimento;

c) as condições de contorno das barras em temperatura ambiente são invariantes com a temperatura;

d) os esforços nos apoios e extremidades das barras em temperatura ambiente são invariantes com temperatura.

$\mathrm{Na}$ elaboração das tabelas de dimensionamento, consideraram-se os efeitos das deformações térmicas resultantes de gradientes de temperatura.

As tabelas 6.10 à 6.13 fornecem o tempo requerido de resistência ao incêndio em função de dimensões mínimas características da seção transversal e do nível de carga $\eta_{f i}$ - relação entre o valor do esforço de cálculo na barra para os estados limites últimos em situação de incêndio e o valor da resistência de cálculo em temperatura ambiente. 
TABELA 6.10 : Dimensões mínimas da seção transversal de pilares mistos totalmente revestidos em função do tempo requerido de resistência ao incêndio

\begin{tabular}{|l|l|c|c|c|c|}
\hline & & \multicolumn{3}{|c|}{} \\
(min)
\end{tabular}

TABELA 6.11: Recobrimento de concreto com função apenas de isolamento térmico

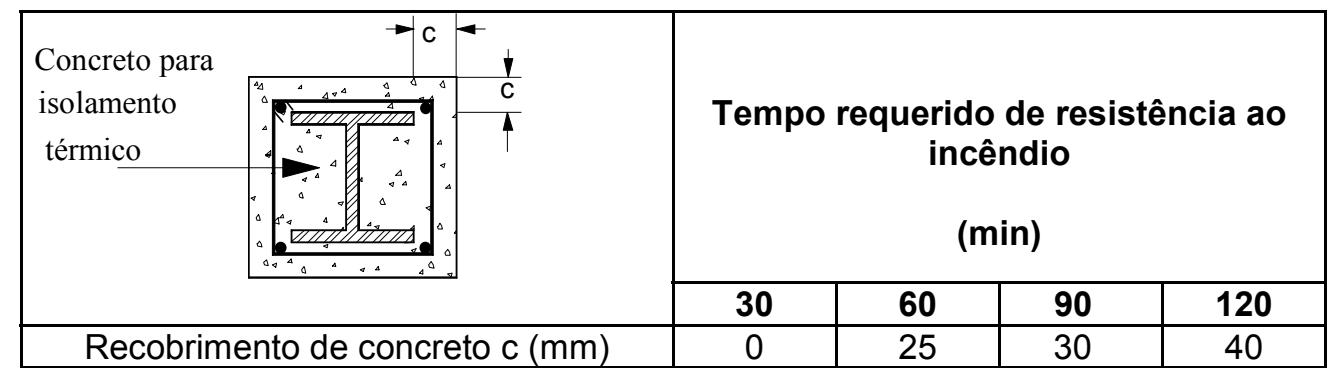


TABELA 6.12: Dimensões mínimas da seção transversal de pilares mistos parcialmente revestidos em função do tempo requerido de resistência ao incêndio

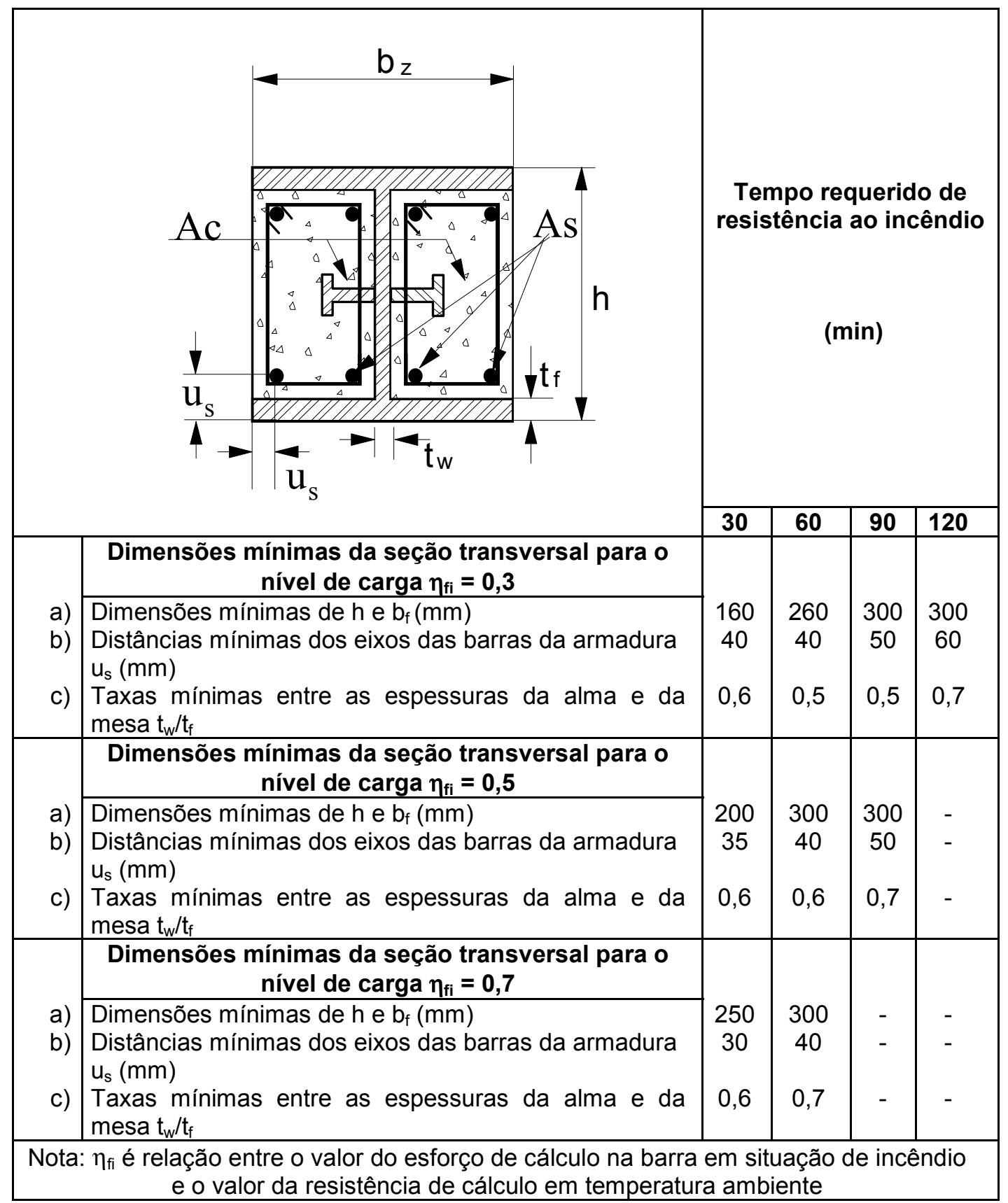


TABELA 6.13 : Dimensões mínimas da seção transversal de pilares mistos preenchidos em função do tempo requerido de resistência ao incêndio

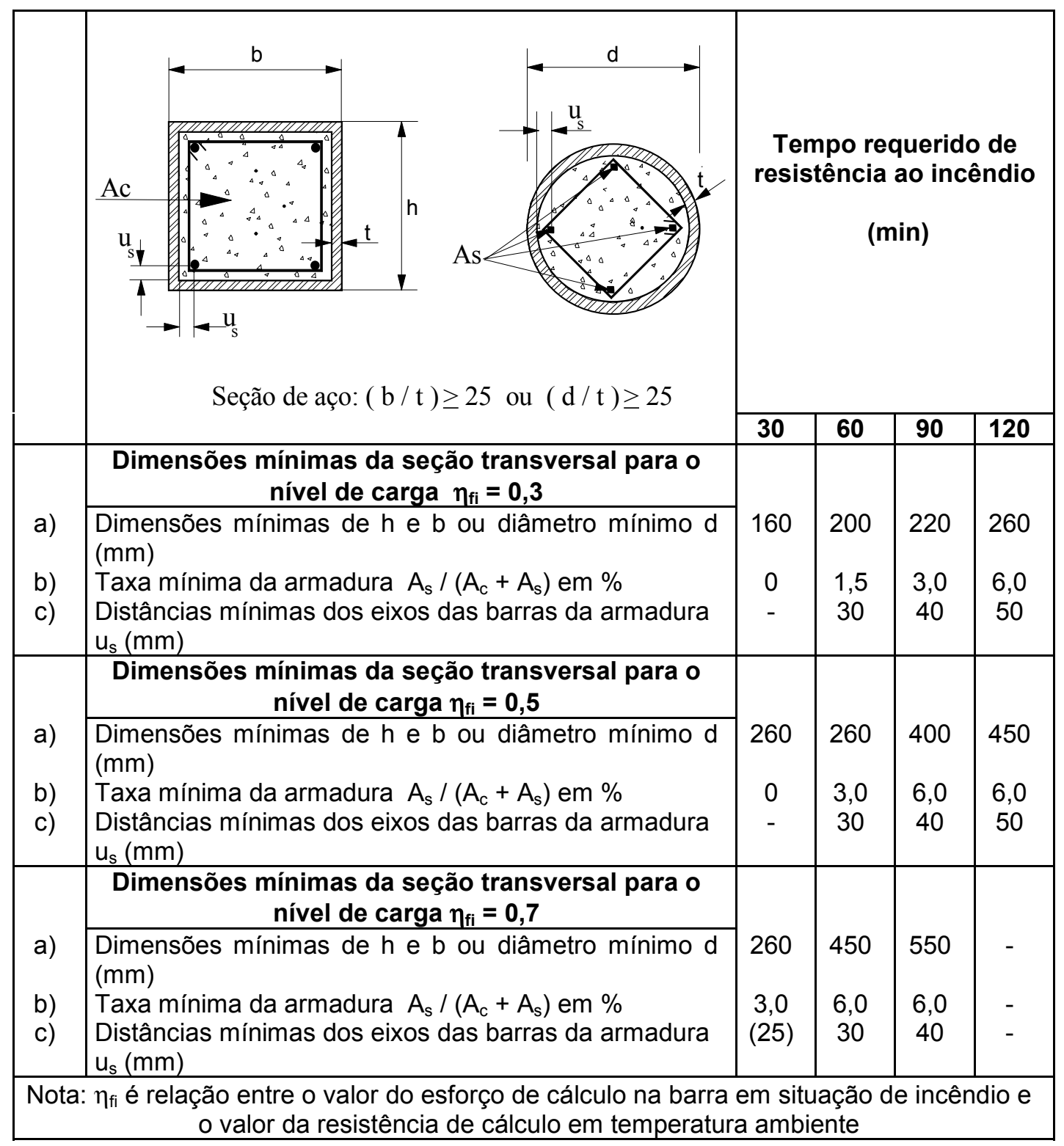


Com base em resultados empíricos, LIE \& STRINGER (1993) apresentaram a seguinte expressão para o cálculo do tempo de resistência ao fogo de pilares mistos preenchidos:

$t_{R}=k \frac{\left(f_{c k}+20\right)}{(K L-1000)} d^{2} \sqrt{\frac{d}{N_{n}}}$

onde

$t_{R}$ é o tempo de resistência ao fogo em minutos, com a restrição $t_{R} \leq 120 \mathrm{~min}$;

$f_{c k}$ é a resistência característica à compressão do concreto, em $\mathrm{MPa}$;

$K L$ é o comprimento efetivo de flambagem, em mm;

$d$ é o diâmetro externo ou largura do pilar, em mm;

$N_{n}$ é a força normal de utilização no pilar, em $\mathrm{kN}$;

$k$ é um coeficiente que ajusta a resistência ao fogo para os diversos tipos de pilares preenchidos. KODUR (1999) apresenta uma tabela para a determinação desse coeficiente, em função do tipo de agregado utilizado, da presença ou não de armadura longitudinal e do recobrimento de concreto. Os valores variam entre 0,06 a 0,095 (ver tabela 6.14).

TABELA 6.14: Valores do coeficiente $k$ da equação (6.41) para pilares preenchidos

\begin{tabular}{|c|c|c|c|c|c|c|c|c|c|c|}
\hline \multirow{3}{*}{$\begin{array}{c}\text { Tipo de } \\
\text { agregado } \\
\text { Taxa de } \\
\text { armadura }\end{array}$} & \multicolumn{2}{|c|}{ Pilares sem armadura } & \multicolumn{8}{|c|}{ Pilares com armadura } \\
\hline & Silicatos & Carbonatos & \multicolumn{4}{|c|}{ Silicatos } & \multicolumn{4}{|c|}{ Carbonatos } \\
\hline & - & - & & $3 \%$ & & $3 \%$ & & $3 \%$ & & $3 \%$ \\
\hline $\begin{array}{c}\text { Recobrimento } \\
\text { de concreto }\end{array}$ & - & - & $\begin{array}{l}<25 \\
\mathrm{~mm}\end{array}$ & $\begin{array}{r}\geq 25 \\
m m\end{array}$ & $\begin{array}{l}<25 \\
m m\end{array}$ & $\begin{array}{l}\geq 25 \\
\mathrm{~mm}\end{array}$ & $\begin{array}{l}<25 \\
m m\end{array}$ & $\begin{array}{l}\geq 25 \\
m m\end{array}$ & $\begin{array}{l}<25 \\
m m\end{array}$ & $\begin{array}{l}\geq 25 \\
\mathrm{~mm}\end{array}$ \\
\hline $\begin{array}{c}\text { Seção } \\
\text { Circular }\end{array}$ & 0,07 & 0,08 &, 075 & ,08 & ,08 & ,085 & ,085 & ,09 & ,09 & ,095 \\
\hline $\begin{array}{c}\text { Seção } \\
\text { Quadrada }\end{array}$ & 0,06 & 0,07 & 065 & ,07 & ,07 &, 075 & 075 & 08 & ,08 & 085 \\
\hline
\end{tabular}




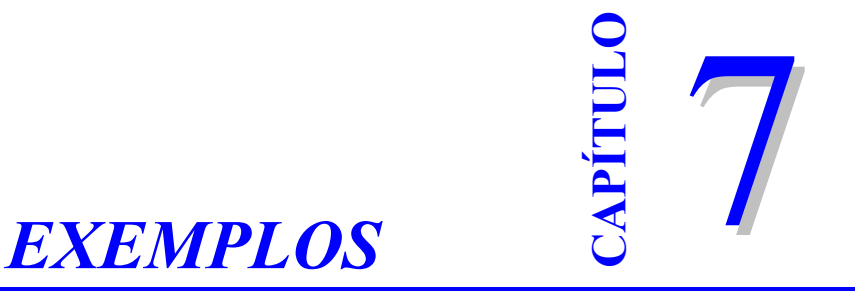

\subsection{INTRODUÇÃO}

Neste capítulo são desenvolvidos três exemplos de dimensionamento de elementos estruturais mistos de edifícios, cujos resultados obtidos com base nas principais normas aplicáveis são comparados e analisados.

O primeiro exemplo (item 7.2.1) trata do dimensionamento de uma viga mista simplesmente apoiada, aplicando-se a NBR 8800, onde é analisado tanto o caso de interação completa quanto de interação parcial. Alguns procedimentos de cálculo das normas estrangeiras são abordados neste exemplo.

O segundo exemplo (item 7.2.2) trata do dimensionamento de uma viga mista contínua de dois tramos, os quais apresentam mesmo vão e mesmas ações atuantes da viga mista simplesmente apoiada do item 7.2.1. A norma aplicada é o EUROCODE 4: Parte 1-1. Comparações importantes de resultados são feitas entre essas duas vigas, devido à diferença de comportamento estrutural entre a viga mista contínua e a simplesmente apoiada. Pretende-se com essas comparações avaliar a diferença, em termos de capacidade estrutural, da viga mista contínua com contribuição da armadura e a viga de aço isolada, conforme prescreve a norma brasileira NBR 8800 .

O terceiro exemplo (item 7.3) trata da verificação de um pilar misto preenchido de seção quadrada, submetido à flexo-compressão. Nesse exemplo é enfatizada a construção da curva de interação momento-normal de elementos flexocomprimidos, com base no EUROCODE 4 e NBR 14323. 


\subsection{EXEMPLOS DE VERIFICAÇÃO DE VIGAS MISTAS}

\subsubsection{EXEMPLO 1}

Este exemplo refere-se a uma viga mista simplesmente apoiada, considerada como parte de um sistema de piso de um edifício. O vão da viga é de $10 \mathrm{~m}$ e o espaçamento entre vigas, $3,50 \mathrm{~m}$. A viga mista é formada por um perfil de aço soldado tipo "I" duplamente simétrico e laje maciça de concreto, conforme ilustra a figura 7.1. Como método construtivo, optou-se pela construção escorada.

Pretende-se, neste exemplo, determinar a resistência ao momento fletor, admitindo-se tanto a interação completa quanto a interação parcial. Com relação aos estados limites de utilização, pretende-se verificar o deslocamento vertical da viga (flecha), considerando inclusive os efeitos da fluência e da retração do concreto. Inicialmente, o dimensionamento será realizado com base na norma brasileira NBR 8800 (1986), com posterior comparação de resultados com as demais normas.

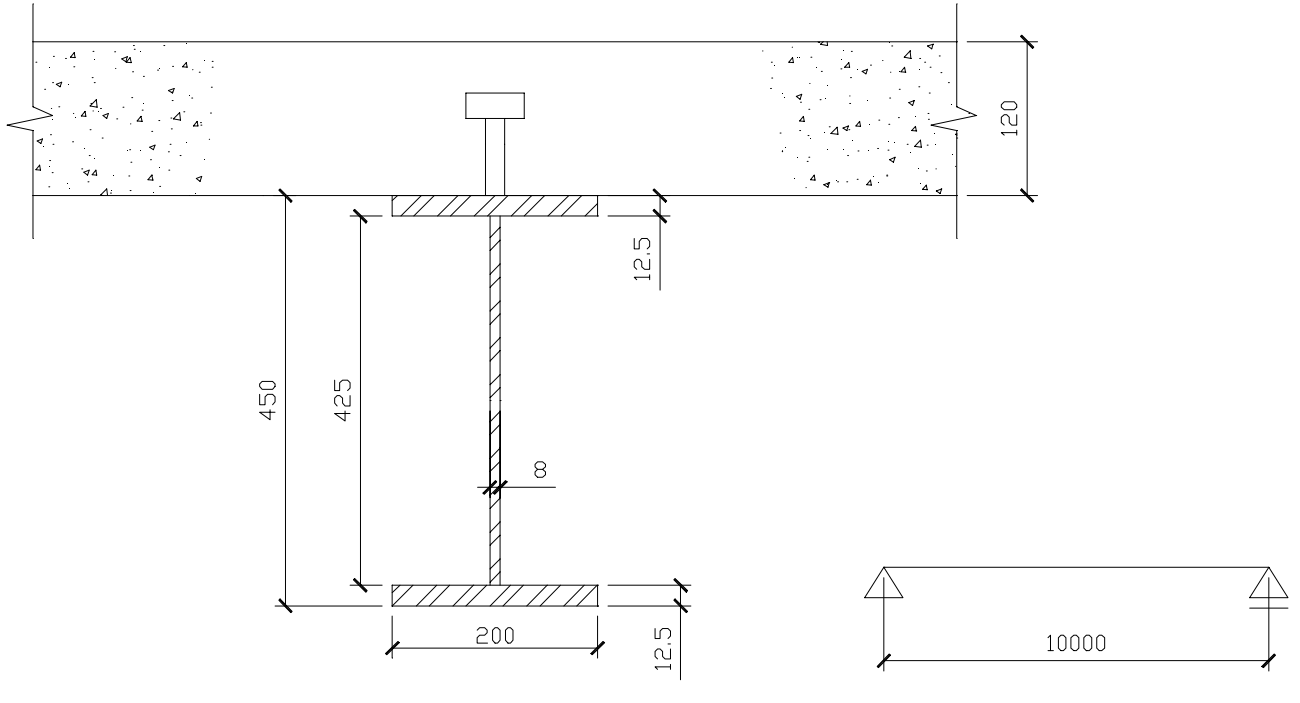

a) Seção transversal $\quad$ b) Esquema estático

FIGURA 7.1: Dimensões da seção da viga mista - exemplo 1 
a) Materiais:

- aço do perfil:

$f_{y}=250 \mathrm{MPa}$

$E=205.000 \mathrm{MPa}$

- concreto:

$f_{c k}=25 \mathrm{MPa}$

$\gamma_{c}=24 \mathrm{kN} / \mathrm{m}^{3}$

$E_{c}=42 \gamma_{c}^{1,5} \sqrt{f_{c k}}=24.691 \mathrm{MPa}$

b) Dimensões da viga de aço:
$d=450 \mathrm{~mm}$
$b_{f}=200 \mathrm{~mm}$
$h_{w}=425 \mathrm{~mm}$
$t_{f}=12,5 \mathrm{~mm}$
$t_{w}=8,0 \mathrm{~mm}$

c) Características geométricas:

- Viga de aço:
$A_{a}=84,0 \mathrm{~cm}^{2}$
$W_{a}=1.290 \mathrm{~cm}^{3}$
$I_{a}=29.043 \mathrm{~cm}^{4}$
$Z_{p a}=1.455 \mathrm{~cm}^{3} \quad$ (módulo de resistência plástico)

- Largura efetiva:

Seguindo as recomendações da NBR 8800, a largura efetiva assume o menor dos seguintes valores:

$$
\begin{aligned}
& \frac{L}{4}=\frac{10.000}{4}=2.500 \mathrm{~mm} \\
& 16 t_{c}+b_{f}=16 \times 120+200=2.120 \mathrm{~mm} \\
& b_{f}+\left(s_{v}-b_{f}\right)=3.500 \mathrm{~mm}
\end{aligned}
$$

Portanto, a largura efetiva b é igual a $2.120 \mathrm{~mm}$ 
- Seção homogeneizada:

Coeficiente de homogeneização:

$n=\frac{E}{E_{c}}=\frac{205.000}{24.691}=8,30 \quad$ (ações de curta duração)

$n=\frac{E}{E_{c} / 3}=\frac{205.000}{24.691 / 3}=24,91 \quad$ (ações de longa duração $\Rightarrow$ EUROCODE 4)

Momento de inércia da seção homogeneizada:

1) $\operatorname{para} \mathrm{n}=8,30$

Posição do centro de gravidade $\left(y_{c g}\right)$, medido a partir do topo da laje:

$y_{c g}=\frac{6,0 \times\left(\frac{212}{8,30} \times 12\right)+34,5 \times(84,0)}{\left(\frac{212}{8,30} \times 12+84,0\right)}=12,13 \mathrm{~cm}$

Momento de inércia:

$$
\begin{aligned}
& I_{t r}=(12,13-6,0)^{2} \times\left(\frac{212}{8,30} \times 12\right)+\frac{212}{8,30} \times \frac{12^{3}}{12}+(34,5-12,13)^{2}(84,0)+29.043 \\
& I_{t r}=86.274 \mathrm{~cm}^{4}
\end{aligned}
$$

2) Para $\mathrm{n}=24,91$ :

Posição do centro de gravidade $\left(y_{c g}\right)$, medido a partir do topo da laje:

$y_{c g}=\frac{6,0 \times\left(\frac{212}{24,91} \times 12\right)+34,5 \times(84,0)}{\left(\frac{212}{24,91} \times 12+84,0\right)}=18,86 \mathrm{~cm}$

Momento de inércia:

$$
\begin{aligned}
& I_{t r}=(18,86-6,0)^{2} \times\left(\frac{212}{24,91} \times 12\right)+\frac{212}{24,91} \times \frac{12^{3}}{12}+(34,5-18,86)^{2}(84,0)+29.043 \\
& I_{t r}=67.706 \mathrm{~cm}^{4}
\end{aligned}
$$




\section{d) Ações:}

As ações sobre a viga mista estão indicadas a seguir:

- permanente: $g_{k}=13 \mathrm{kN} / \mathrm{m}$

- variável: $q_{k}=16 \mathrm{kN} / \mathrm{m}$

Combinação para os estados limites últimos:

$1,4 \times g_{k}+1,5 \times q_{k}=44 \mathrm{kN} / \mathrm{m}$

\section{e) Esforços solicitantes:}

Momento solicitante de cálculo na metade do vão:

$$
M_{S d}=\frac{44 \times 10^{2}}{8}=550 \mathrm{kN} . \mathrm{m}
$$

Força cortante solicitante de cálculo nos apoios:

$V_{S d}=\frac{44,4 \times 10}{2}=220 \mathrm{kN}$

\section{f) Momento fletor resistente de cálculo}

f.1) Admitindo-se interação completa:

Inicialmente, determina-se a classe da alma da viga de aço:

$\frac{h_{w}}{t_{w}}=\frac{425}{8}=53<3,5 \sqrt{\frac{E}{f_{y}}}=100 \Rightarrow$ classe 2 , pois $\lambda_{p l}=67$

Posição da linha neutra da seção plastificada:

$a=\frac{\left(A f_{y}\right)_{a}}{0,66 f_{c k} b}=\frac{84,0 \times 25}{0,66 \times 2,5 \times 212}=6,00 \mathrm{~cm}<t_{c}$

$\therefore$ linha neutra plástica na laje

O momento fletor resistente de cálculo $\phi_{b} M_{n}$ é calculado por: 
$T=\left(A f_{y}\right)_{a}=84,0 \times 25=2.100 \mathrm{kN}$

$M_{n}=T\left(d_{1}+h_{F}+t_{c}-\frac{a}{2}\right)$

$M_{n}=2.100\left(22,5+0+12-\frac{6,00}{2}\right)=66.150 \mathrm{kN} \cdot \mathrm{cm}$

$\phi_{b} M_{n}=0,9 \times 66.150=59.535 \mathrm{kN} . \mathrm{cm}$

ou

$\phi_{b} M_{n}=595 \mathrm{kN} \cdot \mathrm{m}>M_{S d}=550 \mathrm{kN} \cdot \mathrm{m} \quad(\mathrm{ok} !)$

f.2) Admitindo-se interação parcial:

O valor mínimo da resistência global da conexão aço-concreto $\left(Q_{n}\right)$ permitido pela NBR 8800 corresponde ao grau de conexão 0,5. A título de exemplo apenas, será adotado grau de conexão igual a 0,5 .

$Q_{n}=0,5 \times 2.100=1.050 \mathrm{kN}$

O momento fletor resistente de cálculo pode ser determinado com o novo valor da resultante de compressão na laje de concreto:

$C=\left(\frac{0,7}{0,9}\right) Q_{n}=817 \mathrm{kN}$

Calculando-se as demais resultantes, tem-se:

$C^{\prime}=0,5(2 \cdot 100-817)=642 \mathrm{kN}$

$\left(A f_{y}\right)_{t f}=1,25 \times 20 \times 25=625 \mathrm{kN}$

$C^{\prime}>\left(A f_{y}\right)_{t f} \Rightarrow$ linha neutra plástica na alma

$\bar{y}=\frac{C^{\prime}-\left(A f_{y}\right)_{t f}}{\left(A f_{y}\right)_{w}} h_{w}+t_{f}=\frac{642-625}{(42,5 \times 0,8) \times 25} \times 42,5+1,25=2,08 \mathrm{~cm}$ 


$$
\begin{aligned}
& y_{c}=\frac{\frac{1,25}{2} \times(20 \times 1,25)+\left(\frac{1,25+2,08}{2}\right) \times(2,08-1,25) \times 0,8}{(20 \times 1,25)+(2,08-1,25) \times 0,8}=0,65 \mathrm{~cm} \\
& y_{t}=\frac{84,0 \times 22,5-(45-0,65)(20 \times 1,25+(2,08-1,25) \times 0,8)}{84,0-(20 \times 1,25+(2,08-1,25) \times 0,8)}=12,89 \mathrm{~cm} \\
& a=\frac{C}{0,66 f_{c k} b}=\frac{817}{0,66 \times 2,5 \times 212}=2,33 \mathrm{~cm} \\
& M_{n}=C^{\prime}\left(d-y_{t}-y_{c}\right)+C\left(t_{c}-\frac{a}{2}+h_{F}+d-y_{t}\right) \\
& M_{n}=642(45-12,89-0,65)+817\left(12-\frac{2,33}{2}+0+45-12,89\right) \\
& M_{n}=55.283 \mathrm{kN} . \mathrm{cm} \\
& \phi_{b} M_{n}=0,9 \times 55283=49.754 \mathrm{kN} . \mathrm{cm} \\
& \text { ou } \\
& \phi_{b} M_{n}=498 \mathrm{kN} . \mathrm{m}<M_{S d}=550 \mathrm{kN} . \mathrm{m} \quad \text { (não ok!) }
\end{aligned}
$$

Neste caso, deve-se adotar um valor maior para o grau de conexão de modo que a resistência ao momento fletor seja pelo menos igual ao momento solicitante de cálculo.

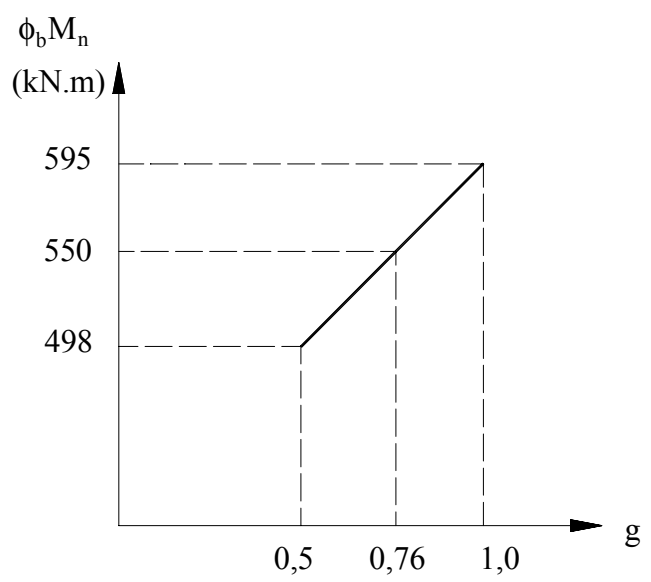

Por simplificação, a resistência da conexão $Q_{n}$ será obtida por interpolação linear a partir do gráfico momento resistente de cálculo x grau de conexão. Dessa interpolação, tem-se que $Q_{n}=0,76 \times 2100=1596 \mathrm{kN}$ 
A tabela 7.1 contém uma comparação entre a relação dos momentos solicitantes de cálculo e os momentos resistentes de cálculo, obtidos com os critérios de ações e segurança de cada norma abordada.

TABELA 7.1: Comparação entre os resultados obtidos de diversas normas

\begin{tabular}{|l|c|c|c|}
\hline \multicolumn{1}{|c|}{ Norma } & $\begin{array}{c}\boldsymbol{M}_{\boldsymbol{R} \boldsymbol{d}} \\
(\boldsymbol{k} \boldsymbol{N . m})\end{array}$ & $\begin{array}{c}\boldsymbol{M}_{\boldsymbol{S} \boldsymbol{d}} \\
(\boldsymbol{k} \boldsymbol{N} \cdot \boldsymbol{m})\end{array}$ & $\boldsymbol{M}_{\boldsymbol{S d}} / \boldsymbol{M}_{\boldsymbol{R} \boldsymbol{d}}$ \\
\hline NBR 8800 (1986) & 595 & 550 & 0,924 \\
\hline AISC-LRFD (1994) & 581 & 515 & 0,886 \\
\hline CAN/CSA-S16.1 (1994) & 596 & 538 & 0,903 \\
\hline EUROCODE 4 (1992) & 607 & 519 & 0,856 \\
\hline BS 5950 (1990) & 646 & 548 & 0,848 \\
\hline
\end{tabular}

A comparação dos valores da tabela 7.1 indica que, com respeito à determinação do momento fletor resistente em vigas mistas, as normas citadas conduzem a resultados próximos entre si.

\section{g) Ligação aço-concreto - conectores de cisalhamento:}

Para se ter interação completa,

$$
Q_{n} \geq\left\{\begin{array}{l}
\left(A f_{y}\right)_{a}=2.100 k \mathrm{~N} \\
0,85 f_{c k} b t_{c}=5.406 \mathrm{kN}
\end{array}\right.
$$

Será adotado o valor mínimo necessário para a caracterização da interação completa, ou seja, $Q_{n}=2.100 \mathrm{kN}$.

Número de conectores de cisalhamento:

Escolheu-se o conector tipo pino com cabeça, de diâmetro igual a $22 \mathrm{~mm}$, altura do pino igual a $100 \mathrm{~mm}$ e resistência do aço do conector igual a $450 \mathrm{MPa}$.

A capacidade nominal do conector é calculada conforme a expressão (2.1), obtendo-se o seguinte valor: 
$q_{n}=149 \mathrm{kN}$

número de conectores necessários entre a seção de momento máximo e a seção do apoio: $\frac{Q_{n}}{q_{n}}=\frac{2.100}{149}=14,09 \cong 14$

Adotando-se um conector por fila, tem-se que espaçamento longitudinal entre conectores é igual a:

$e=\frac{5.000}{14}=357 \mathrm{~mm} \quad$ (valor a ser ajustado no detalhamento)

Os espaçamentos máximos e mínimos recomendados pela NBR 8800 são:

$e_{\max }=8 t_{c}=960 \mathrm{~mm}$

$e_{\text {min }}=6 d=132 \mathrm{~mm}$

Portanto, os critérios de espaçamento estão satisfeitos.

No caso de interação parcial, o procedimento para obter o número de conectores é o mesmo, bastando utilizar o novo valor de $Q_{n}$ :

$\frac{Q_{n}}{q_{n}}=\frac{1596}{149}=10,7 \Rightarrow 11$ conectores

Adotando-se um conector por fila, o espaçamento longitudinal é igual a:

$\frac{5000}{11}=455 \mathrm{~mm} \quad$ (valor que deve ser ajustado no detalhamento)

\section{h) Verificação de deslocamentos}

Os momentos de inércia da seção homogeneizada, para os respectivos coeficientes de homogeneização, são:

$I_{t r}=86.274 \mathrm{~cm}^{4}$ para $n=8,30$

$I_{t r}=67.706 \mathrm{~cm}^{4} \quad$ para $n=24,91$

- Cálculo das flechas na viga mista: 
- Considerando interação completa:

$$
\begin{array}{ll}
\delta_{g}=\frac{5 \times 0,13 \times 1.000^{4}}{384 \times 20.500 \times 67.706}=1,22 \mathrm{~cm} & (\text { ações permanentes }) \\
\delta_{q}=\frac{5 \times 0,16 \times 1.000^{4}}{384 \times 20.500 \times 86.274}=1,18 \mathrm{~cm} \equiv \frac{L}{847}<\frac{L}{360} \quad \text { (ações variáveis) }
\end{array}
$$

Logo, o deslocamento total é dado por:

$$
\delta=\delta_{g}+\delta_{q}=1,22+1,18=2,40 \mathrm{~cm} \equiv \frac{L}{417}
$$

O valor $L / 360$ é o deslocamento vertical admissível para as ações variáveis, segundo a NBR 8800. A norma brasileira, no entanto, não específica o valor admissível para as ações permanentes. Neste caso, pode-se comparar o deslocamento total com o valor $L / 250$, que é o deslocamento total admissível segundo o EUROCODE 3.

Caso se tivesse optado pela construção não escorada, os deslocamentos devem ser obtidos com a soma de duas parcelas: o deslocamento da viga de aço isolada na etapa de construção e o deslocamento da seção mista da etapa em serviço.

Etapa de construção: $7 \mathrm{kN} / \mathrm{m}$

Etapa de serviço: $22 \mathrm{kN} / \mathrm{m}$

$$
\delta=\frac{5 \times 0,07 \times 1.000^{4}}{384 \times 20.500 \times 29043}+\frac{5 \times 0,22 \times 1.000^{4}}{384 \times 20.500 \times 86274}=3,15 \mathrm{~cm}=\frac{L}{317}
$$

- Considerando interação parcial:

Neste caso, os momentos de inércia da seção homogeneizada $I_{t r}$ devem ser substituídos pelos momentos de inércia efetivos $I_{e f}$, a fim de considerar o escorregamento ao nível da ligação aço-concreto: 
$I_{e f}=I_{a}+\sqrt{\frac{Q_{n}}{V_{h}}}\left(I_{t r}-I_{a}\right) \quad$ (expressão 3.25)

Neste exemplo, para efeito de comparação com o caso de interação completa, será adotado grau de conexão igual a 0,5 , ou seja,

$$
\frac{Q_{n}}{V_{h}}=0,5
$$

Assim,

$I_{e f}=29.043+\sqrt{0,5}(86.274-29.043)=69.511 \mathrm{~cm}^{4} \quad($ para $n=8,30)$

$I_{e f}=29.043+\sqrt{0,5}(67.706-29.043)=56.382 \mathrm{~cm}^{4} \quad($ para $n=24,91)$

$\delta_{g}=\frac{5 \times 0,13 \times 1.000^{4}}{384 \times 20.500 \times 56.382}=1,47 \mathrm{~cm}$

$\delta_{q}=\frac{5 \times 0,16 \times 1.000^{4}}{384 \times 20.500 \times 69.511}=1,46 \mathrm{~cm}$

O deslocamento total é dado por:

$\delta=\delta_{g}+\delta_{q}=1,47+1,46=2,93 \mathrm{~cm} \equiv \frac{L}{341}$

A norma canadense CAN/CSA-S16.1 (1994) também apresenta uma expressão que considera o efeito da interação parcial no deslocamento vertical, o qual é calculado substituindo-se $I_{t r}$ pelo momento de inércia efetivo $I_{e f}$ :

$$
\begin{aligned}
& I_{e f}=I_{a}+0,85 p^{0,25}\left(I_{t r}-I_{a}\right) \quad \text { (expressão 3.28) } \\
& p=\frac{Q_{n}}{V_{h}}=0,5 \\
& I_{e f}=29.043+0,85 \times(0,5)^{0,25}(67.706-29.043)=56.678 \mathrm{~cm}^{4} \quad(\text { para } \mathrm{n}=24,91) \\
& I_{e f}=29.043+0,85 \times(0,5)^{0,25}(86.274-29.043)=69.950 \mathrm{~cm}^{4} \quad(\text { para } \mathrm{n}=8,30) \\
& \delta_{g}=\frac{5 \times 0,13 \times 1.000^{4}}{384 \times 20.500 \times 56.678}=1,46 \mathrm{~cm} \\
& \delta_{q}=\frac{5 \times 0,16 \times 1.000^{4}}{384 \times 20.500 \times 69.950}=1,45 \mathrm{~cm}
\end{aligned}
$$


$\delta=\delta_{g}+\delta_{q}=1,46+1,45=2,91 \mathrm{~cm}$

(praticamente o mesmo valor obtido com a NBR 8800)

A flecha admitindo interação parcial (com o mínimo grau de conexão permitido) resultou em um valor $21 \%$ maior que a flecha obtida no caso de interação completa.

\section{i) Efeito da retração nos deslocamentos}

O EUROCODE 4 recomenda que o efeito da retração deve ser considerado em vigas mistas cuja relação vão/altura exceda 20 ou quando a deformação por retração for maior que $400 \times 10^{-6}$. Neste exemplo, não seria necessária a consideração, pois:

$\frac{\text { vão }}{\text { altura }}=\frac{10.000}{570}=17,5<20$

$\varepsilon_{c s}=325 \times 10^{-6}$

(Este valor de deformação é sugerido pelo EUROCODE 4 para ambientes secos e concreto de densidade normal)

No entanto, caso seja necessário avaliar o efeito da retração, o deslocamento vertical na metade do vão pode ser determinado pela seguinte expressão:

$\delta_{s}=\frac{N_{s} e_{s} L^{2}}{8 E I_{t r}}$

A força normal $N_{s}$ resultante da retração é calculada por:

$$
\begin{aligned}
& N_{s}=\left(\frac{E_{c}}{3}\right) b t_{c} \varepsilon_{c s} \\
& N_{s}=\frac{2.469}{3} \times 212 \times 12 \times 325 \times 10^{-6}=680 \mathrm{kN}
\end{aligned}
$$

A excentricidade $e_{s}$ da resultante de retração (ver figura 7.2) é igual a:

$e_{s}=y_{c g}-\frac{t_{c}}{2}=18,86-6,0=12,86 \mathrm{~cm}$ 


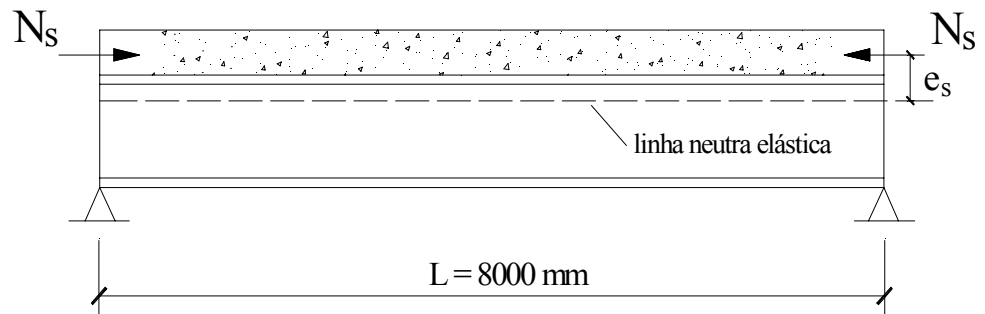

FIGURA 7.2: Efeito da retração sobre a viga mista do exemplo 1

Substituindo valores:

$\delta_{s}=\frac{680 \times 12,86 \times 1.000^{2}}{8 \times 20.500 \times 67.706}=0,79 \mathrm{~cm} \quad$ (interação completa)

Este valor representa aproximadamente $30 \%$ do deslocamento obtido para a interação completa sem retração $(2,40 \mathrm{~cm})$, portanto, relativamente significativo. 


\subsubsection{EXEMPLO 2}

Este exemplo refere-se a uma viga mista contínua, considerada como parte de um sistema de piso de um edifício. A viga é constituída por dois tramos de mesmo vão, igual a 10,0 m. O espaçamento entre vigas é 3,50 m. A seção transversal da viga mista é a mesma do exemplo 1, acrescentando-se apenas a armadura longitudinal, conforme indicado na figura 7.3.

Pretende-se, neste exemplo, determinar a resistência ao momento fletor da viga mista contínua, admitindo-se interação completa, além de verificar a estabilidade lateral da viga e a interação momento-cortante. Com relação aos estados limites de utilização, serão verificados o deslocamento vertical da viga e o efeito da fissuração do concreto na região de momento fletor negativo. Algumas comparações e discussões importantes serão feitas durante o desenvolvimento deste exemplo. A norma utilizada será o EUROCODE 4: Parte 1-1.

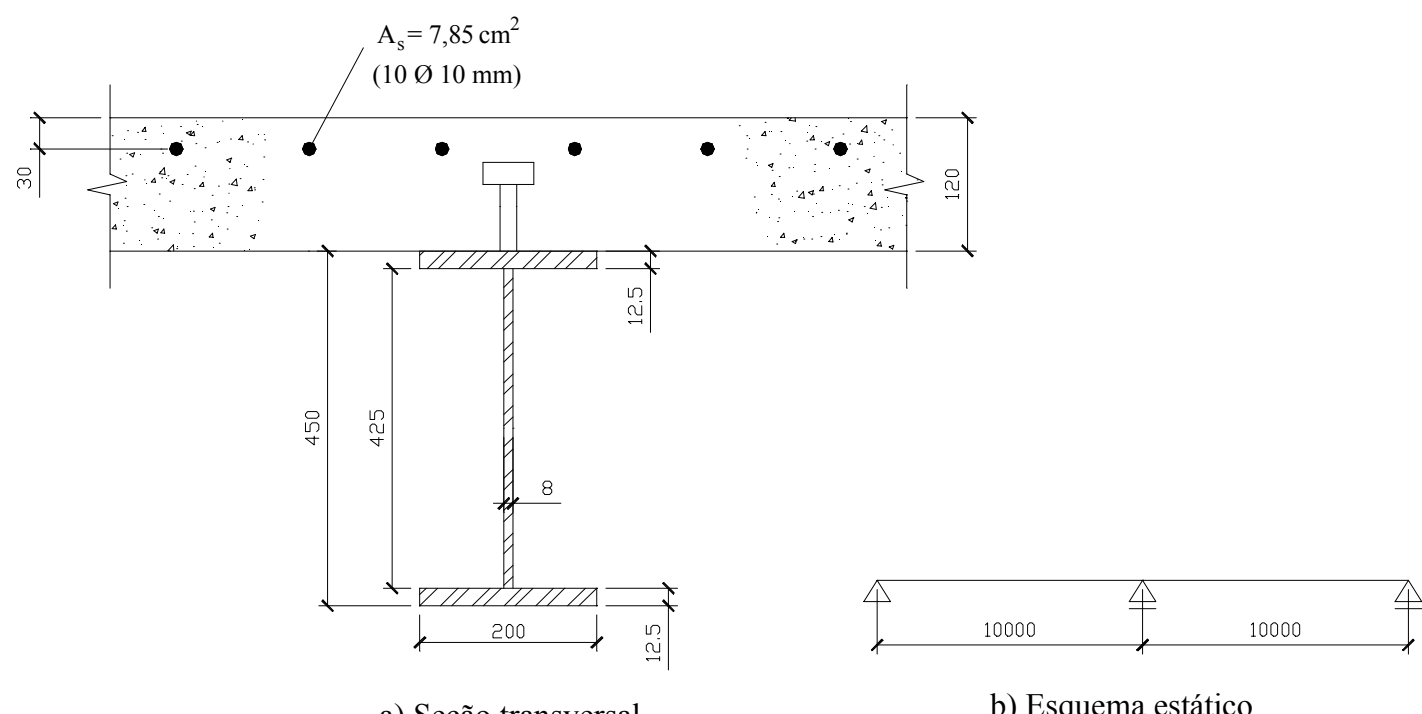

a) Seção transversal

b) Esquema estático

FIGURA 7.3: Viga mista contínua - exemplo 2

a) Materiais

- Aço do perfil:

$f_{y}=250 \mathrm{MPa}$ 
$E=210.000 \mathrm{MPa}$

- concreto:

$f_{c k}=25 \mathrm{MPa}$

$E_{c}=30.500 \mathrm{MPa} \quad$ (conforme EUROCODE 4: Parte 1-1.)

- aço da armadura:

$f_{s y}=500 \mathrm{MPa}$

b) Dimensões da viga de aço e da laje de concreto:

São as mesmas do exemplo 1.

c) Armadura longitudinal:

Diâmetro das barras: $10 \mathrm{~mm}$

Distância do centro de gravidade das barras à face superior da laje : $30 \mathrm{~mm}$

d) Características geométricas:

- Viga de aço:

São as mesmas do exemplo 1 .

- Armadura longitudinal:

$\mathrm{A}_{\mathrm{s}}=7,85 \mathrm{~cm}^{2}$

- Largura efetiva:

A largura efetiva assume os seguintes valores: (vide figuras 3.4 e 3.5 )

$b=0,125 L=1.250 \mathrm{~mm}$ na região do apoio interno

$b=0,200 L=2.000 \mathrm{~mm}$ na metade do vão da viga

- Seção homogeneizada: 
Coeficiente de homogeneização:

$n=\frac{E}{E_{c}}=\frac{210.000}{30.500}=6,89 \quad$ (ações de curta duração)

$n=\frac{E}{E_{c} / 3}=\frac{210.000}{30.500 / 3}=20,66 \quad$ (ações de longa duração)

Momento de inércia da seção homogeneizada:

- $\quad$ Seção do apoio $(b=1.250 \mathrm{~mm})$

1) Seção "não fissurada"

Para $\mathrm{n}=6,89$ :

Posição do centro de gravidade $\left(y_{c g}\right)$, medido a partir do topo da laje:

$$
y_{c g}=\frac{3,0 \times(7,85)+6,0 \times\left(\frac{125}{6,89} \times 12\right)+34,5 \times(84,0)}{\left(7,85+\frac{125}{6,89} \times 12+84,0\right)}=13,66 \mathrm{~cm}
$$

Momento de inércia:

$$
\begin{aligned}
& I_{1}=(13,66-3,0)^{2} \times 7,85+(13,66-6,0)^{2} \times\left(\frac{125}{6,89} \times 12\right)+\frac{125}{6,89} \times \frac{12^{3}}{12}+ \\
& (34,5-13,66)^{2}(84,0)+29.043 \\
& I_{1}=81.803 \mathrm{~cm}^{4}
\end{aligned}
$$

Para $\mathrm{n}=20,66$ :

Posição do centro de gravidade $\left(y_{c g}\right)$, medido a partir do topo da laje:

$$
y_{c g}=\frac{3,0 \times(7,85)+6,0 \times\left(\frac{125}{20,66} \times 12\right)+34,5 \times(84,0)}{\left(7,85+\frac{125}{20,66} \times 12+84,0\right)}=20,41 \mathrm{~cm}
$$

Momento de inércia: 
$I_{1}=(20,41-3,0)^{2} \times 7,85+(20,41-6,0)^{2} \times\left(\frac{125}{20,66} \times 12\right)+\frac{125}{20,66} \times \frac{12^{3}}{12}+$

$(34,5-20,41)^{2}(84,0)+29.043$

$I_{1}=64.046 \mathrm{~cm}^{4}$

2) Seção "fissurada"

Posição do centro de gravidade $\left(y_{c g}\right)$, medido a partir do topo da laje:

$y_{c g}=\frac{3,0 \times(7,85)+34,5 \times(84,0)}{(7,85+84,0)}=31,81 \mathrm{~cm}$

Momento de inércia:

$I_{2}=(31,81-3,0)^{2} \times 7,85+(34,5-31,81)^{2}(84,0)+29.043$

$I_{2}=36.166 \mathrm{~cm}^{4}$

- Seção na metade do vão $(b=2.000 \mathrm{~mm})$

Para $\mathrm{n}=6,89$ :

Posição do centro de gravidade $\left(y_{c g}\right)$, medido a partir do topo da laje:

$$
y_{c g}=\frac{3,0 \times(7,85)+6,0 \times\left(\frac{200}{6,89} \times 12\right)+34,5 \times(84,0)}{\left(7,85+\frac{200}{6,89} \times 12+84,0\right)}=11,39 \mathrm{~cm}
$$

Momento de inércia:

$$
\begin{aligned}
& I_{t r}=(11,39-3,0)^{2} \times 7,85+(11,39-6,0)^{2} \times\left(\frac{200}{6,89} \times 12\right)+\frac{200}{6,89} \times \frac{12^{3}}{12}+ \\
& (34,5-11,39)^{2}(84,0)+29.043 \\
& I_{t r}=88.757 \mathrm{~cm}^{4}
\end{aligned}
$$

Para $n=20,66$ :

Posição do centro de gravidade $\left(y_{c g}\right)$, medido a partir do topo da laje:

$$
y_{c g}=\frac{3,0 \times(7,85)+6,0 \times\left(\frac{200}{20,66} \times 12\right)+34,5 \times(84,0)}{\left(7,85+\frac{200}{20,66} \times 12+84,0\right)}=17,40 \mathrm{~cm}
$$


Momento de inércia:

$$
\begin{aligned}
& I_{t r}=(17,40-3,0)^{2} \times 7,85+(17,40-6,0)^{2} \times\left(\frac{200}{20,66} \times 12\right)+\frac{200}{20,66} \times \frac{12^{3}}{12}+ \\
& (34,5-17,40)^{2}(84,0)+29.043 \\
& I_{t r}=71.724 \mathrm{~cm}^{4}
\end{aligned}
$$

A tabela 7.2 resume os momentos de inércia calculados:

TABELA 7.2: Momentos de inércia da seção homogeneizada

\begin{tabular}{|c|c|c|c|c|}
\hline Tipo de Ação & $\mathbf{n}$ & \multicolumn{2}{|c|}{ Seção dos apoios } & Seção na metade \\
\cline { 3 - 4 } & & "não fissurada vão & "fissurada" & $88.757 \mathrm{~cm}^{4}$ \\
\hline $\begin{array}{c}\text { Curta duração } \\
\text { (variável) }\end{array}$ & 6,89 & $81.803 \mathrm{~cm}^{4}$ & $36.166 \mathrm{~cm}^{4}$ & \\
\hline $\begin{array}{c}\text { Longa duração } \\
\text { (permanente) }\end{array}$ & 20,66 & $64.046 \mathrm{~cm}^{4}$ & $36.166 \mathrm{~cm}^{4}$ & $71.724 \mathrm{~cm}^{4}$ \\
\hline
\end{tabular}

e) Ações:

São as mesmas do exemplo 1.

Combinações para os estados limites últimos:

$1,35 g_{k}+1,5 q_{k}=42 \mathrm{kN} / \mathrm{m}$

\section{f) Esforços solicitantes de cálculo:}

Momento solicitante de cálculo no apoio interno (sem redistribuição):

$M_{S d}=2 \times \frac{42 \times 10^{2}}{16}=525 \mathrm{kN} . \mathrm{m}$

Classe da seção de aço:

- mesa: $\frac{b_{f}}{2 t_{f}}=\frac{200}{2 \times 12,5}=8<9 \varepsilon=8,7 \Rightarrow$ classe 1 
onde $\varepsilon=\sqrt{\frac{235}{f_{y}}}, \operatorname{com} f_{y}$ em MPa

- alma:

É necessário calcular a altura $(x)$ da zona comprimida na alma, conforme ilustra a figura 7.4, para determinar a classe da alma.

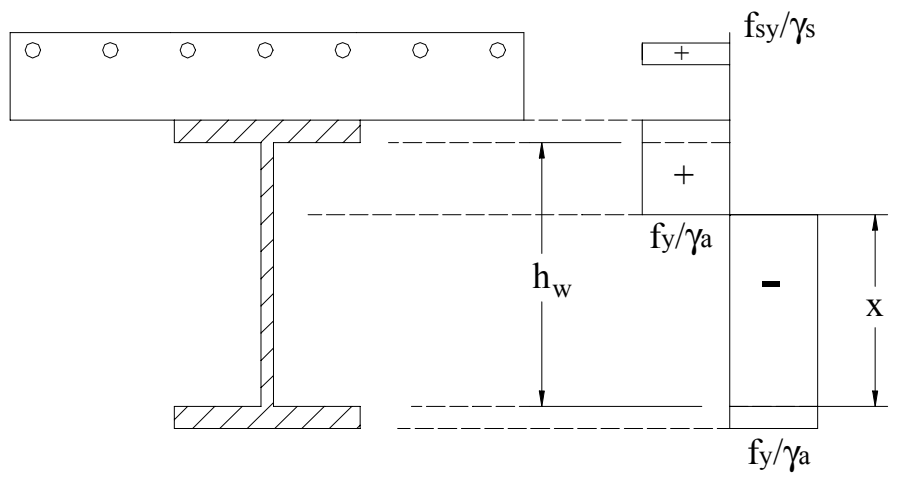

Seção transversal Distribuição de tensões

FIGURA 7.4: Tensões na seção mista - exemplo 2

Por equilíbrio de forças:

$\left(b_{f} t_{f}\right) \frac{f_{y}}{\gamma_{a}}+\left(x t_{w}\right) \frac{f_{y}}{\gamma_{a}}=\left(h_{w}-x\right) t_{w} \frac{f_{y}}{\gamma_{a}}+\left(b_{f} t_{f}\right) \frac{f_{y}}{\gamma_{a}}+A_{s} \frac{f_{s y}}{\gamma_{s}}$

Substituindo-se os valores, encontra-se o valor de $x$ :

$x=30,6 \mathrm{~cm}$

A relação $(\alpha)$ entre a altura comprimida e sua altura total é igual a:

$\alpha=\frac{x}{h_{w}}=\frac{30,6}{42,5}=0,72>0,5$

De acordo com a tabela 4.2 do EUROCODE 4: Parte 1-1, a alma de um perfil de aço soldado pertence à classe 2 se:

$\frac{396 \varepsilon}{(13 \alpha-1)}<\frac{h_{w}}{t_{w}} \leq \frac{456 \varepsilon}{(13 \alpha-1)} \quad$ para $\alpha>0,5$

Neste caso, $\operatorname{com} \alpha=0,72$

$45<\frac{h_{w}}{t_{w}} \leq 53$ 
Sendo a relação largura/espessura da alma da seção deste exemplo igual a $\frac{425}{8}=53$, a alma pertence à classe 2 .

Portanto, a seção também pertence à classe 2 (a classe mais desfavorável entre mesa e alma)

Tratando-se de seções classe 2, a redistribuição de momentos é feita com a redução de $30 \%$ do momento inicial do apoio (ver tabela 3.4 para a análise elástica da seção "não fissurada"). Portanto, após a redistribuição:

$M_{S d}=0,7 \times 525=368 \mathrm{kN} . \mathrm{m} \quad$ (apoio)

$M_{S d}^{\prime}=357 \mathrm{kN} . \mathrm{m} \quad$ (máximo momento positivo de cálculo)

$V_{s d}=247 \mathrm{kN} \quad$ (máxima força cortante de cálculo - apoio)

A figura 7.5 ilustra o diagrama de momentos fletores solicitantes de cálculo após a redistribuição de momentos:

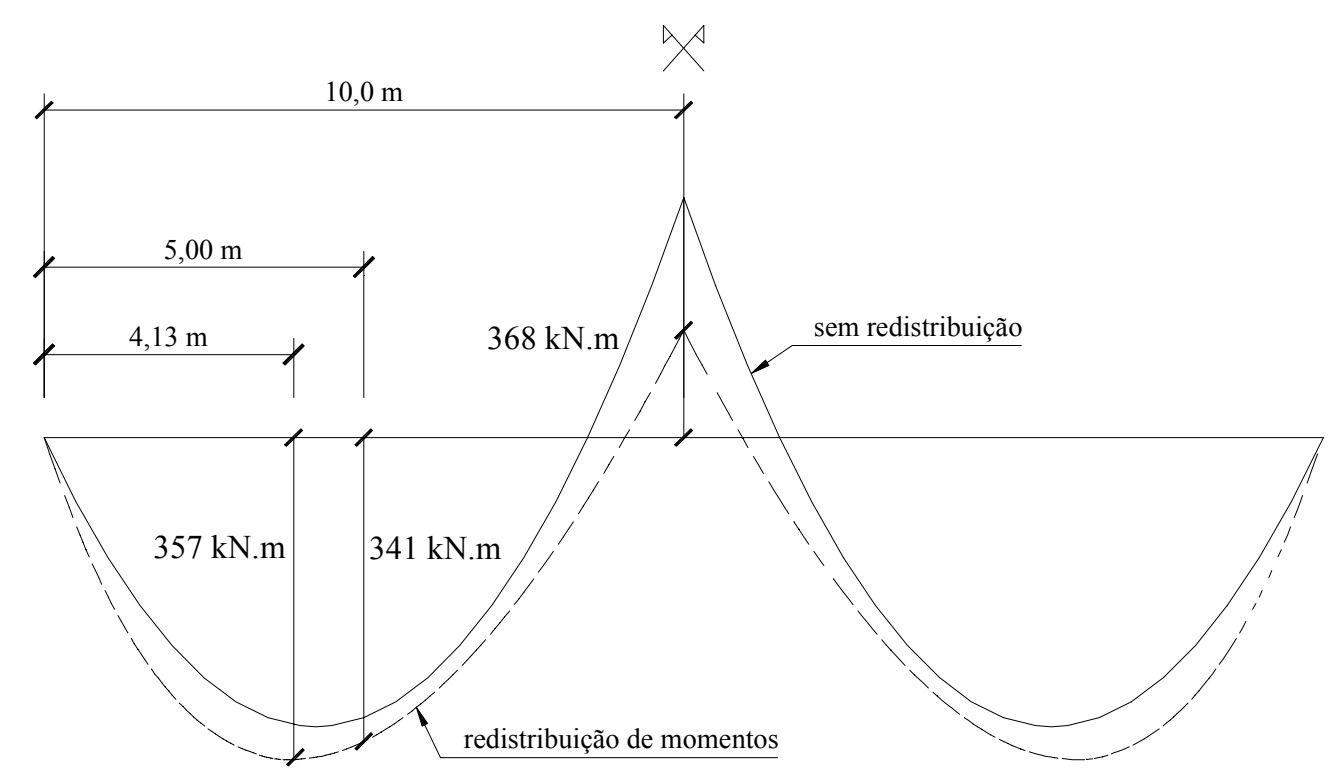

FIGURA 7.5: Momentos solicitantes de cálculo após a redistribuição

g) Resistência ao momento fletor negativo: 


$$
\begin{aligned}
& R_{s}=\frac{A_{s} f_{s y}}{\gamma_{s}}=\frac{7,85 \times 50}{1,15}=341 \mathrm{kN} \\
& R_{a}=\frac{A_{a} f_{y}}{\gamma_{a}}=\frac{84,0 \times 25}{1,1}=1.909 \mathrm{kN} \\
& R_{w}=\frac{h_{w} t_{w} f_{y}}{\gamma_{a}}=\frac{42,5 \times 0,8 \times 25}{1,1}=773 \mathrm{kN}
\end{aligned}
$$

A linha neutra plástica intercepta a alma, pois $R_{s}<R_{w}$.

Assim, o momento resistente é dado por:

$$
M_{R d}=\left(M_{p l, R d}\right)_{a}+R_{s}\left(\frac{d}{2}+h_{s}\right)-\frac{R_{s}^{2}}{R_{w}} \frac{h_{w}}{4} \quad(\text { expressão 3.59) }
$$

onde

$$
\begin{aligned}
& \left(M_{p l, R d}\right)_{a}=\frac{Z_{p a} f_{y}}{\gamma_{a}}=\frac{1455 \times 25}{1,1}=33.068 \mathrm{kN} . \mathrm{cm} \\
& h_{s}=12,0-3,0=9,0 \mathrm{~cm}
\end{aligned}
$$

substituindo-se os valores:

$$
\begin{aligned}
& M_{R d}=33.068+341 \times\left(\frac{45}{2}+9,0\right)-\frac{341^{2}}{773} \times \frac{42,5}{4} \\
& M_{R d}=42.211 \mathrm{kN} . \mathrm{cm} \quad \text { ou } \\
& M_{R d}=422 \mathrm{kN} . \mathrm{m}>M_{S d}=368 \mathrm{kN} . \mathrm{m} \quad(\mathrm{ok} !)
\end{aligned}
$$

\section{h) Resistência ao momento fletor positivo:}

$$
\begin{aligned}
& b=0,200 L=2.000 \mathrm{~mm} \\
& R_{c}=\frac{0,85 f_{c k} b t_{c}}{\gamma_{c}}=\frac{0,85 \times 2,5 \times 200 \times 12}{1,5}=3.400 \mathrm{kN} \\
& R_{a}=\frac{A_{a} f_{y}}{\gamma_{a}}=\frac{84,0 \times 25}{1,1}=1.909 \mathrm{kN}
\end{aligned}
$$

Como $R_{c}>R_{a}$, a linha neutra situa-se na laje. Utilizando a expressão (3.36) calculase a resistência ao momento fletor positivo para interação completa: 


$$
\begin{aligned}
& M_{R d}=R_{a}\left(\frac{d}{2}+t_{c}+h_{F}-\frac{R_{a}}{R_{c}} \frac{t_{c}}{2}\right) \\
& M_{R d}=1.909\left(\frac{45}{2}+12+0-\frac{1.909}{3.400} \times \frac{12}{2}\right)=59.429 \mathrm{kN} . \mathrm{cm} \\
& M_{R d}=594 \mathrm{kN} . \mathrm{m}>M_{S d}^{\prime}=357 \mathrm{kN} . \mathrm{m} \quad(\mathrm{ok} !)
\end{aligned}
$$

\section{i) Resistência à força cortante:}

$$
\begin{aligned}
& V_{p l, R d}=\left(h_{w} t_{w}\right) \frac{f_{y}}{\sqrt{3}} \frac{1}{\gamma_{a}} \quad(\text { expressão 3.63) } \\
& V_{p l, R d}=(42,5 \times 0,8) \frac{25}{\sqrt{3}} \times \frac{1}{1,1}=446 \mathrm{kN}>V_{S d}=247 \mathrm{kN} \quad(\mathrm{ok} !)
\end{aligned}
$$

A verificação da flambagem local da alma por cisalhamento não é necessária neste caso, pois:

$$
\frac{h_{w}}{t_{w}}=53<69 \varepsilon=67
$$

\section{j) Interação momento-cortante:}

Como a força cortante solicitante de cálculo é maior que $50 \%$ da força cortante resistente de cálculo $\left(\frac{V_{S d}}{V_{p l, R d}}=0,55\right)$, deve-se obedecer o critério de interação da expressão (3.64):

$M_{S d} \leq M_{f, R d}+\left(M_{R d}-M_{f, R d}\left[1-\left(\frac{2 V_{S d}}{V_{p l, R d}}-1\right)^{2}\right]\right.$

$M_{f, R d}$ é o momento resistente de cálculo considerando apenas a contribuição das mesas. Logo,

$$
\begin{aligned}
& M_{f, R d}=\frac{Z^{\prime} f_{y}}{\gamma_{a}} \\
& Z^{\prime}=2\left(\frac{d-t_{f}}{2}\right)\left(b_{f} \times t_{f}\right)=2 \times\left(\frac{45-1,25}{2}\right) \times(20 \times 1,25)=1.094 \mathrm{~cm}^{3}
\end{aligned}
$$


$M_{f, R d}=1.094 \times \frac{25}{1,1}=24.864 \mathrm{kN} . \mathrm{cm}$

$M_{S d} \leq 24.864+(42.211-24.864)\left[1-\left(\frac{2 \times 247}{446}-1\right)^{2}\right]=42.010 \mathrm{kN} . \mathrm{cm}$

$M_{S d}=36.800 \mathrm{kN} . \mathrm{cm}<42.010 \mathrm{kN} . \mathrm{cm}$

$\therefore$ a expressão de interação está satisfeita.

\section{k) Instabilidade por distorção:}

A flambagem associada à distorção da seção transversal da viga de aço pode ocorrer em vigas mistas submetidas a momentos negativos.

A verificação da estabilidade não é necessária caso o coeficiente $\bar{\lambda}_{L T}$, apresentado na expressão (3.70) para perfis de aço tipo "I" duplamente simétricos, não assuma valores maiores que 0,4 :

$\bar{\lambda}_{L T}=5,0\left(1+\frac{t_{w} h_{a}}{4 b_{f} t_{f}}\right)\left[\left(\frac{f_{y}}{E C_{4}}\right)^{2}\left(\frac{h_{a}}{t_{w}}\right)^{3}\left(\frac{t_{f}}{b_{f}}\right)\right]^{0,25}$

onde

$h_{a}=437,5 \mathrm{~mm} \quad$ (distância entre centros de mesas)

$\mathrm{C}_{4}$ é um coeficiente que depende da distribuição de momentos fletores ao longo do vão e é apresentado no anexo B do EUROCODE 4: Parte 1-1. Para a distribuição de momentos deste exemplo, $\mathrm{C}_{4}=27,7$.

Substituindo valores:

$\bar{\lambda}_{L T}=5,0\left(1+\frac{8,0 \times 437,5}{4 \times 200 \times 12,5}\right)\left[\left(\frac{25}{21.000 \times 27,7}\right)^{2}\left(\frac{437,5}{8}\right)^{3}\left(\frac{12,5}{200}\right)\right]^{0,25}$

$\bar{\lambda}_{L T}=0,445>0,4 \quad \therefore$ é necessária a verificação da estabilidade lateral

$\mathrm{O}$ momento resistente à flambagem por distorção $M_{b, R d}$, para seções pertencentes à classe 1 ou 2, é dado por: 
$M_{b, R d}=\chi_{L T} M_{p l, R d}\left(\frac{\gamma_{a}}{\gamma_{R d}}\right) \quad \operatorname{com} \gamma_{R d}=1,0$

O valor de $\chi_{L T}$ é determinado por:

$$
\chi_{L T}=\frac{1}{\varphi_{L T}+\left(\varphi_{L T}^{2}-\bar{\lambda}_{L T}^{2}\right)^{\frac{1}{2}}} \quad \operatorname{com} \chi_{L T} \leq 1
$$

onde

$\varphi_{L T}=0,5\left[1+\alpha_{L T}\left(\bar{\lambda}_{L T}-0,2\right)+\bar{\lambda}_{L T}^{2}\right]$

$\alpha_{L T}=0,49 \quad$ (perfil soldado)

$\bar{\lambda}_{L T}=0,445$

Substituindo valores:

$\varphi_{L T}=0,659$

$\chi_{L T}=0,873$

Finalmente:

$M_{b, R d}=0,873 \times 42.211=36.850 \mathrm{kN} . \mathrm{cm}$

$\mathrm{ou}$

$M_{b, R d}=369 \mathrm{kN} \cdot \mathrm{m}>M_{S d}=368 \mathrm{kN} \cdot \mathrm{m} \quad(\mathrm{ok} !)$

\section{l) Ligação aço-concreto - conectores de cisalhamento:}

Neste exemplo, a interação completa está sendo admitida. Para a determinação da resistência da ligação, é necessário analisar duas regiões distintas do tramo da viga:

- Trecho da viga entre a seção de momento positivo máximo e a seção do apoio externo (momento nulo):

$$
\begin{aligned}
& R_{c}=0,85 \times 200 \times 12 \times \frac{2,5}{1,5}=3.400 \mathrm{kN} \\
& R_{a}=\frac{84 \times 25}{1,1}=1.909 \mathrm{kN}
\end{aligned}
$$


$\therefore Q_{R d}=1.909 \mathrm{kN}$

- Trecho da viga entre a seção de momento máximo positivo e a seção de momento máximo negativo (apoio interno):

$Q_{R d}=F_{p}+F_{n} \quad($ expressão 3.62$)$

onde

$F_{p}$ é o menor valor entre $\frac{0,85 f_{c k} b t_{c}}{\gamma_{c}}=3.400 \mathrm{kN}$ e $\frac{A_{a} f_{y}}{\gamma_{a}}=1.909 \mathrm{kN}$

$F_{n}=\frac{A_{s} f_{s y}}{\gamma_{s}}=\frac{7,85 \times 50}{1,15}=341 \mathrm{kN}$

Substituindo valores:

$Q_{R d}=1.909+341=2.250 \mathrm{kN}$

Utilizando conectores tipo pino com cabeça de diâmetro igual a $22 \mathrm{~mm}$, altura igual a $100 \mathrm{~mm}$ e resistência do aço do conector igual a $450 \mathrm{MPa}$, tem-se que:

$q_{R d}=98 \mathrm{kN} \quad($ expressão 2.4$)$

O número de conectores de cisalhamento e o espaçamento longitudinal, para os dois trechos distintos, podem ser determinados por:

$$
\begin{array}{lll}
N=\frac{1.909}{98}=19,48 & \Rightarrow 20 \text { conectores } & e=\frac{4125}{20}=206 \mathrm{~mm} \\
N=\frac{2.250}{98}=22,96 & \Rightarrow 23 \text { conectores } & e=\frac{5875}{23}=255 \mathrm{~mm}
\end{array}
$$

Será adotado um espaçamento uniforme em todo o tramo, igual a $200 \mathrm{~mm}$.

Logo, o número total de conectores é igual a:

$\frac{L}{e}=\frac{10000}{200}=50$ conectores

m) Verificação de deslocamentos: 
Para levar em conta o efeito da fissuração nos deslocamentos, deve-se multiplicar os momentos negativos do apoio, obtidos pelo cálculo elástico (sem redistribuição) por um fator de redução $f_{l}$, conforme a expressão (3.71):

$f_{1}=\left(\frac{I_{1}}{I_{2}}\right)^{-0,35} \quad \operatorname{com} 0,6 \leq f_{1} \leq 1,0$

Ações permanentes: $\quad(\mathrm{n}=20,66)$

$I_{1}=64.046 \mathrm{~cm}^{4} \quad$ (seção "não fissurada")

$I_{2}=36.166 \mathrm{~cm}^{4} \quad$ (seção "fissurada")

$f_{1}=\left(\frac{64.046}{36.166}\right)^{-0,35}=0,819$

Ações variáveis: $\quad(\mathrm{n}=6,89)$

$I_{1}=81.803 \mathrm{~cm}^{4}$

$I_{2}=36.166 \mathrm{~cm}^{4}$

$f_{1}=\left(\frac{81.803}{36.166}\right)^{-0,35}=0,752$

A situação em que ocorre o maior deslocamento vertical na viga é quando o carregamento das ações variáveis atua em apenas um dos tramos:
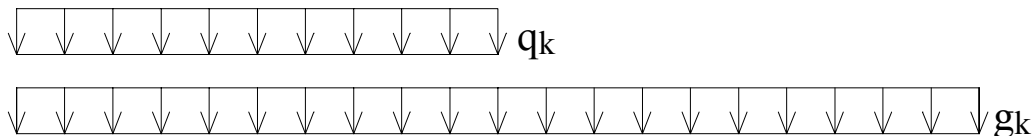

Os momentos fletores solicitantes das ações características devem ser determinados pelo processo elástico, após o qual devem ser redistribuídos, segundo os respectivos fatores de redução $f_{l}$ aplicados aos momentos negativos. De posse do novo diagrama de momentos, é possível calcular a flecha da viga por meio de qualquer método da hiperestática clássica. 
A norma britânica BS 5950 fornece uma expressão simplificada para o cálculo do deslocamento vertical na metade de vão:

$\delta=\delta_{0}\left[1-0,6\left(\frac{M_{1}+M_{2}}{M_{0}}\right)\right] \quad($ expressão 3.78$)$

onde

$\delta_{0}$ e $M_{0}$ são o deslocamento vertical e o momento fletor, respectivamente, na metade do vão de uma viga simplesmente apoiada de mesmo vão. Os valores dos momentos de inércia da seção mista para o cálculo de $\delta_{0}$ encontram-se na tabela 7.2 $M_{1}$ e $M_{2}$ são os momentos fletores de extremidade do tramo analisado Substituindo valores:

$$
\begin{aligned}
& \delta_{0}=\frac{5 \times 0,13 \times 1.000^{4}}{384 \times 21.000 \times 71.724}+\frac{5 \times 0,16 \times 1.000^{4}}{384 \times 21.000 \times 88.757}=2,24 \mathrm{~cm} \\
& M_{0}=\frac{(13+16) \times 10^{2}}{8}=363 \mathrm{kN} . \mathrm{m} \\
& M_{1}=0 \\
& M_{2}=\frac{13 \times 10^{2}}{8}+\frac{16 \times 10^{2}}{16}=263 \mathrm{kN} . \mathrm{m} \\
& \delta=2,24 \times\left[1-0,6\left(\frac{0+263}{363}\right)\right] \\
& \delta=1,27 \mathrm{~cm} \equiv \frac{L}{787}<\frac{L}{250} \quad \text { (valor recomendado pelo EUROCODE 3) }
\end{aligned}
$$

Comparando-se este valor com o obtido no caso de viga simplesmente apoiada de mesmo vão e mesmas ações, observa-se uma redução de aproximadamente $50 \%$ no valor da flecha.

\section{n) Fissuração do concreto:}

Caso não seja requerido nenhum controle da abertura de fissuras no concreto, basta apenas que seja atendido o critério de armadura mínima que, no caso de construção escorada, deve ser igual ou superior a $0,4 \%$ da área efetiva da laje: 
$\frac{0,4}{100} \times(125 \times 12)=6,0 \mathrm{~cm}^{2}$

$A_{s}=7,85 \mathrm{~cm}^{2}>6,0 \mathrm{~cm}^{2} \quad(\mathrm{ok} !)$

Se for necessário o controle da abertura de fissuras, a área mínima de armadura longitudinal é dada por:

$A_{s}=K K_{c} f_{c t} \frac{A_{c t}}{\sigma_{s t}} \quad($ expressão 3.72)

onde

$K=0,8$

$K_{c}=\frac{1}{1+\frac{t_{c}}{2 z_{0}}}$

$z_{0}$ é a distância entre o centro de gravidade da laje e o centro de gravidade da seção homogeneizada, desconsiderando-se a armadura, e calculada por:

$z_{0}=y_{c g}-\frac{t_{c}}{2}$

$y_{c g}=13,93 \mathrm{~cm} \quad$ (desconsiderando a armadura)

$z_{0}=13,93-\frac{12,0}{2}=7,93 \mathrm{~cm}$

$K_{c}=\frac{1}{1+\frac{12}{2 \times 7,93}}=0,57 \quad$ porém $K_{c} \leq 0,7$

$\therefore K_{c}=0,7$

$f_{c t}=0,30 \mathrm{kN} / \mathrm{cm}^{2}=3,0 \mathrm{MPa}$

$A_{c t}=125 \times 12=1500 \mathrm{~cm}^{2}$

Os valores de $\sigma_{s t}$ são obtidos consultando-se a tabela 3.5:

$\sigma_{s t}=36 \mathrm{kN} / \mathrm{cm}^{2}(\equiv 360 \mathrm{MPa})$ para abertura de fissura $0,3 \mathrm{~mm}$

$\sigma_{s t}=50 \mathrm{kN} / \mathrm{cm}^{2}$ ( $\equiv 360 \mathrm{MPa}$ ) para abertura de fissura $0,5 \mathrm{~mm}$

Substituindo valores:

$\left(A_{s}\right)_{\min }=0,8 \times 0,7 \times 0,3 \times \frac{1.500}{36}=7,0 \mathrm{~cm}^{2} \quad$ para abertura de fissura $0,3 \mathrm{~mm}$ 
$\left(A_{s}\right)_{\min }=0,8 \times 0,7 \times 0,3 \times \frac{1.500}{50}=5,0 \mathrm{~cm}^{2} \quad$ para abertura de fissura $0,5 \mathrm{~mm}$

Como $A_{s}=7,85 \mathrm{~cm}^{2}$, o critério também está satisfeito.

\section{COMPARAÇÃO DA RESISTÊNCIA AO MOMENTO FLETOR : VIGA SIMPLESMENTE APOIADA E VIGA CONTÍNUA}

Sabe-se que, em regiões de momentos negativos, devido à fissuração do concreto e da instabilidade por distorção do perfil de aço, a resistência ao momento fletor é menor que em regiões de momentos positivos. A partir disso, analisam-se dois pontos:

- avaliação da perda de eficiência do sistema misto, quando submetido a momentos negativos;

- discussão da hipótese de admitir apenas a contribuição da viga de aço isolada na resistência ao momento fletor negativo, conforme recomenda a NBR 8800 .

A tabela 7.3 contém os momentos resistentes de cálculo de três situações possíveis: a viga de aço isolada, a viga mista simplesmente apoiada e a viga mista contínua.

TABELA 7.3: Resistência ao momento fletor (em kN.m)

\begin{tabular}{|c|c|c|c|c|c|}
\hline \multirow{2}{*}{ Norma } & \multicolumn{2}{|c|}{ Viga de aço isolada } & $\begin{array}{c}\text { Viga mista } \\
\text { s. apoiada }\end{array}$ & \multicolumn{2}{c|}{ Viga mista contínua } \\
\cline { 2 - 6 } & Com FLT & Sem FLT & $1 / 2$ do vão & $1 / 2$ vão & apoio \\
\hline NBR 8800 & 109 & 327 & 595 & 595 & 109 \\
\hline EUROCODE 4 & 138 & 331 & 598 & 594 & $422^{(*)}$ \\
\hline $\begin{array}{l}\left.{ }^{*}\right) \\
\text { Utilizando uma taxa de armadura ligeiramente maior }(0,52 \%)\end{array}$ \\
para o combate à fissuração (0,47\%). \\
Nota: FLT - flambagem lateral com torção (estado limite último) \\
\hline
\end{tabular}


Comparando os resultados obtidos pelo EUROCODE 4 para os exemplos $1 \mathrm{e}$ 2, constata-se que a resistência ao momento fletor da viga mista contínua é cerca de $30 \%$ menor em relação à da viga mista simplesmente apoiada. Vale observar que a taxa de armadura adotada no exemplo 2 (viga mista contínua) assumiu um valor ligeiramente maior que a armadura mínima requerida para o combate à fissuração.

A diferença entre a resistência ao momento fletor negativo da viga contínua e da viga de aço isolada é significativa; neste exemplo, as seguintes diferenças foram observadas:

- Ao se admitir a flambagem lateral com torção (FLT), o momento resistente da viga de aço isolada é cerca de três vezes menor que o momento resistente da viga mista contínua;

- Sem admitir FLT, o momento resistente da viga de aço é cerca de 30\% menor que o momento resistente da viga mista contínua.

A não consideração de FLT parece ser mais razoável, visto que a laje oferece uma restrição lateral à viga de aço. Entretanto, dependendo da seção transversal da viga de aço, especialmente da relação largura/espessura da alma, existe a possibilidade de ocorrência da instabilidade por distorção; portanto, a não consideração de FLT seria contra a segurança.

A principal razão que justifica a diferença no último caso (sem admitir FLT da viga) é que a norma brasileira não considera a parcela de resistência da armadura da laje. Por esse motivo, percebe-se que a recomendação da NBR 8800 é conservadora, havendo necessidade de revisão. 


\subsection{EXEMPLO DE VERIFICAÇÃO DE PILARES MISTOS}

Neste exemplo é verificado um pilar misto preenchido de seção quadrada, conforme a figura 7.6, submetido à flexo-compressão, onde a flexão ocorre em um dos eixos apenas (eixo x). A verificação é feita segundo as recomendações da norma brasileira NBR 14323, a qual tem como base o método simplificado do EUROCODE 4: Parte 1-1. Dois procedimentos são empregados neste exemplo: o primeiro consiste em verificar se a expressão de interação da norma brasileira é atendida; em seguida, a fim de elucidar o dimensionamento de elementos flexo-comprimidos, verifica-se o pilar utilizando a curva de interação momento-normal apresentada pelo EUROCODE 4: Parte 1-1.

O comprimento efetivo de flambagem do pilar é igual a $400 \mathrm{~cm}$. Os esforços solicitantes de cálculo ( $1^{\circ}$ ordem) são: $M_{S d}=150 \mathrm{kN}$.m e $N_{S d}=1.500 \mathrm{kN}$. O pilar pertence a uma estrutura deslocável.

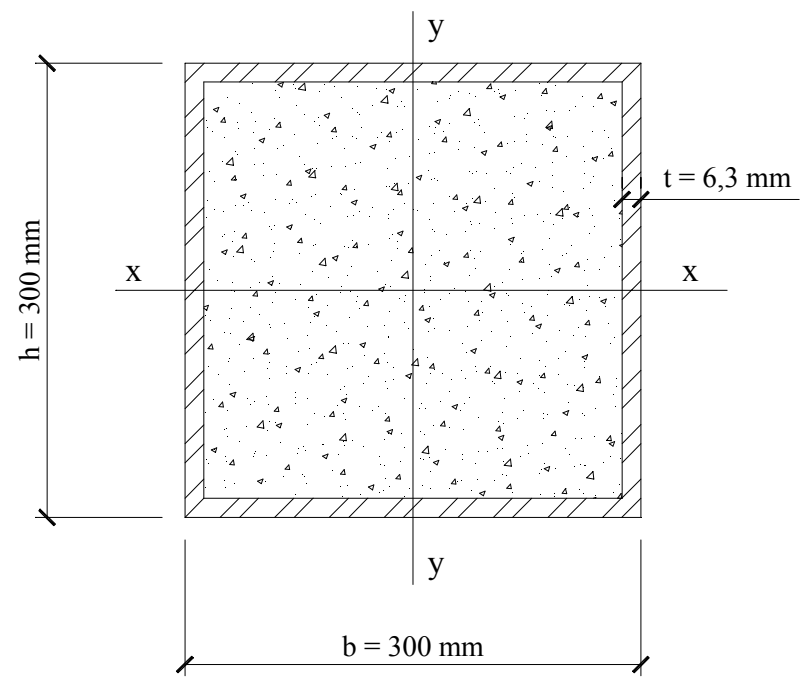

FIGURA 7.6: Seção transversal do pilar misto preenchido - exemplo 3

a) Materiais:

- Aço do perfil:

$$
f_{y}=250 \mathrm{MPa} \quad \phi_{a}=0,9
$$


$E=205.000 \mathrm{MPa}$

$\phi_{a} f_{y}=f_{y d}=225 \mathrm{MPa}$

- concreto:
$f_{c k}=30 \mathrm{MPa}$
$\phi_{c}=0,7$
$E_{c}=27.000 \mathrm{MPa}$
$\phi_{c} f_{c k}=f_{c d}=21 \mathrm{MPa}$

b) Características geométricas:

Perfil de aço:
$A_{a}=73,8 \mathrm{~cm}^{2}$
$W_{a}=706 \mathrm{~cm}^{3}$
$I_{a}=10.600 \mathrm{~cm}^{4}$
$Z_{p a}=812 \mathrm{~cm}^{3}$

Seção de concreto:

$$
\begin{aligned}
& A_{c}=826,0 \mathrm{~cm}^{2} \\
& I_{c}=56.855 \mathrm{~cm}^{4}
\end{aligned}
$$

Posição da linha neutra (vide figura 5.9):

$$
\begin{aligned}
& h_{n}=\frac{A_{c} f_{c d}}{2 b f_{c d}+4 t\left(2 f_{y d}-f_{c d}\right)} \\
& h_{n}=\frac{826,0 \times 2,1}{2 \times 30 \times 2,1+4 \times 0,63 \times(2 \times 22,5-2,1)}=7,41 \mathrm{~cm}
\end{aligned}
$$

Módulos de resistência plásticos na região de altura $2 h_{n}$ :

$$
\begin{aligned}
& Z_{p c}=\frac{(b-2 t)(h-2 t)^{2}}{4} \\
& Z_{p c}=\frac{(30,0-2 \times 0,63)^{3}}{4}=5.935 \mathrm{~cm}^{3} \\
& Z_{p c n}=(b-2 t) h_{n}^{2} \\
& Z_{p c n}=(30,0-2 \times 0,63) \times 7,41^{2}=1.578 \mathrm{~cm}^{3} \\
& Z_{p a n}=b h_{n}^{2}-Z_{p c n}
\end{aligned}
$$




$$
Z_{p a n}=30 \times 7,41^{2}-1578=69,2 \mathrm{~cm}^{3}
$$

Produto de rigidez equivalente:

$$
\begin{aligned}
& (E I)_{e}=E I_{a}+0,8 E_{c} I_{c} \\
& (E I)_{e}=20.500 \times 10.600+0,8 \times 2.700 \times 56.855=340 \times 10^{6} \mathrm{kN} \cdot \mathrm{cm}^{2}
\end{aligned}
$$

c) Parâmetro de contribuição do aço:

$$
\delta=\frac{\phi_{a} f_{y} A_{a}}{N_{p l, R d}}
$$

onde:

$$
\begin{aligned}
& N_{p l, R d}=\phi_{a} f_{y} A_{a}+\alpha \phi_{c} f_{c k} A_{c} \\
& N_{p l, R d}=0,9 \times 25 \times 73,8+1,0 \times 0,7 \times 3,0 \times 826,0=3.395 \mathrm{kN}
\end{aligned}
$$

Substituindo valores:

$\delta=\frac{0,9 \times 25 \times 73,8}{3.395}=0,49 \quad($ para $0,2<\delta<0,9$, o método simplificado se aplica $)$

d) Índice de esbeltez reduzido:

$$
\begin{aligned}
& \bar{\lambda}=\sqrt{\frac{N_{p l, R}}{N_{e}}}, \quad \operatorname{com} N_{p l, R}=N_{p l, R d} \quad \text { calculado com } \phi_{a}=1,0 \text { e } \phi_{c}=1,0 \\
& N_{p l, R}=1,0 \times 25 \times 73,8+1,0 \times 1,0 \times 3,0 \times 826,0=4.323 \mathrm{kN} \\
& N_{e}=\frac{\pi^{2}(E I)_{e}}{(K L)^{2}}=\frac{\pi^{2} \times\left(340 \times 10^{6}\right)}{(400)^{2}}=20.980 \mathrm{kN} \quad \text { (adotado K=1,0) }
\end{aligned}
$$

Substituindo valores:

$\bar{\lambda}=\sqrt{\frac{4.323}{20.980}}=0,454<2,0 \quad \therefore$ o método simplificado se aplica

\section{e) Flambagem local da parede do tubo:}


Para evitar a flambagem local da parede do tubo, a norma NBR 14323 recomenda, de forma similar ao EUROCODE 4, que a relação largura/espessura não ultrapasse o seguinte valor:

$$
\begin{aligned}
& \frac{b}{t} \leq 1,76 \sqrt{\frac{E}{f_{y}}} \\
& \frac{300}{6,3}=47,6<1,76 \sqrt{\frac{20.500}{25}}=50,4 \quad(\mathrm{ok} !)
\end{aligned}
$$

\section{f) Resistência à compressão da seção mista:}

$$
N_{R d}=\rho N_{p l, R d}
$$

O valor de $\rho$ é obtido pela curva "a" da NBR 8800. Assim, para $\bar{\lambda}=0,454$ :

$$
\rho=0,938
$$

$$
N_{R d}=0,938 \times 3.395=3.185 \mathrm{kN}>N_{S d}=1.500 \mathrm{kN} \quad(\mathrm{ok} !)
$$

\section{g) Resistência ao momento fletor da seção mista:}

$$
\begin{aligned}
& M_{p l, R d}=f_{y d}\left(Z_{p a}-Z_{p a n}\right)+0,5 f_{c d}\left(Z_{p c}-Z_{p c n}\right) \\
& M_{p l, R d}=22,5 \times(812-69,2)+0,5 \times 2,1 \times(5.935-1.578) \\
& M_{p l, R d}=21.288 \mathrm{kN} . \mathrm{cm}>M_{S d}=15.000 \mathrm{kN} . \mathrm{cm} \quad(\mathrm{ok} !)
\end{aligned}
$$

\section{h) Verificação da flexão composta:}

$\mu_{k} \frac{N_{S d}-N_{n}}{N_{R d}-N_{n}}+\frac{C_{m x} M_{x, S d}}{\left(1-\frac{N_{S d}-N_{n}}{N_{e x}}\right) 0,9 M_{x, p l, R d}} \leq \mu_{d} \quad$ (expressão 5.2)

onde

$$
\mu_{k}=\frac{N_{p l, R d}-N_{R d}}{N_{p l, R d}-N_{c}}=\frac{3.395-3.185}{3.395-1.735}=0,127 \leq 1,0
$$


$\mu_{d}=\frac{N_{p l, R d}-N_{S d}}{N_{p l, R d}-N_{c}}=\frac{3.395-1.500}{3.395-1.735}=1,14 \quad$ porém $\mu_{d} \leq 1,0 \quad \therefore \quad \mu_{d}=1,0$

$N_{c}=\alpha \phi_{c} f_{c k} A_{c}=1,0 \times 0,7 \times 3,0 \times 826=1.735 \mathrm{kN}$

$C_{m x}=0,85$ (barra pertencente a estrutura deslocável, sem análise de $2^{\circ}$ ordem)

$N_{n}=N_{R d} \frac{(1+r)}{4}=3.185 \frac{(1+0,5)}{4}=1.194 \mathrm{kN}$

$r=\frac{M_{1}}{M_{2}}=0,5 \quad$ (valor adotado para este exemplo)

Substituindo valores:

$0,127 \times \frac{1.500-1.194}{3.185-1.194}+\frac{0,85 \times 15.000}{\left(1-\frac{1.500-1.194}{20.980}\right) \times 0,9 \times 21.288}=0,695<1,0$

Para comparação, será construída a curva de interação momento-normal da figura 5.14, a qual é recomendada pelo EUROCODE 4 na verificação da flexo-compressão. Antes, porém, é necessário determinar os pontos A, B, C e D da figura 5.12:

Ponto A:

$\frac{N_{S d}}{N_{p l, R d}}=1,0$
$\frac{M_{S d}}{M_{p l, R d}}=0$

Ponto B:

$\frac{N_{S d}}{N_{p l, R d}}=0,0$

$\frac{M_{S d}}{M_{p l, R d}}=1,0$

Ponto C:

$\frac{N_{S d}}{N_{p l, R d}}=\frac{N_{c}}{N_{p l, R d}}=\frac{1.735}{3.395}=0,511$

$\frac{M_{S d}}{M_{p l, R d}}=1,0$

Ponto D: 
O momento $M_{\max , R d}$ da figura 5.12 é obtido por:

$M_{m a x, R d}=Z_{p a} f_{y d}+\frac{Z_{p c}}{2} f_{c d}$

$M_{\max , R d}=812 \times 22,5+\frac{5.935}{2} \times 2,1=24.502 \mathrm{kN} . \mathrm{cm}$

Logo:

$\frac{N_{S d}}{N_{p l, R d}}=\frac{0,5 N_{c}}{N_{p l, R d}}=0,256$

$\frac{M_{S d}}{M_{p l, R d}}=\frac{M_{\max , R d}}{M_{p l, R d}}=\frac{24.502}{21.288}=1,15$

Definidos os pontos da curva de interação, é possível fazer a verificação da flexocompressão por meio da seguinte condição:

$M_{S d} \leq 0,9 \mu M_{p l, R d}$

onde

$\mu=\mu_{d}-\mu_{k} \frac{\left(\chi_{d}-\chi_{n}\right)}{\left(\chi-\chi_{n}\right)}$

$\chi=\rho=0,938$

$\chi_{n}=\chi \frac{(1-r)}{4}=0,938 \times\left(\frac{1+0,5}{4}\right)=0,352$

$\chi_{d}=\frac{N_{S d}}{N_{p l, R d}}=\frac{1.500}{3.395}=0,442$

$\left.\begin{array}{l}\mu_{k}=0,127 \\ \mu_{d}=1,04\end{array}\right\}$ obtidos da curva de interação, indicada na figura 7.7 


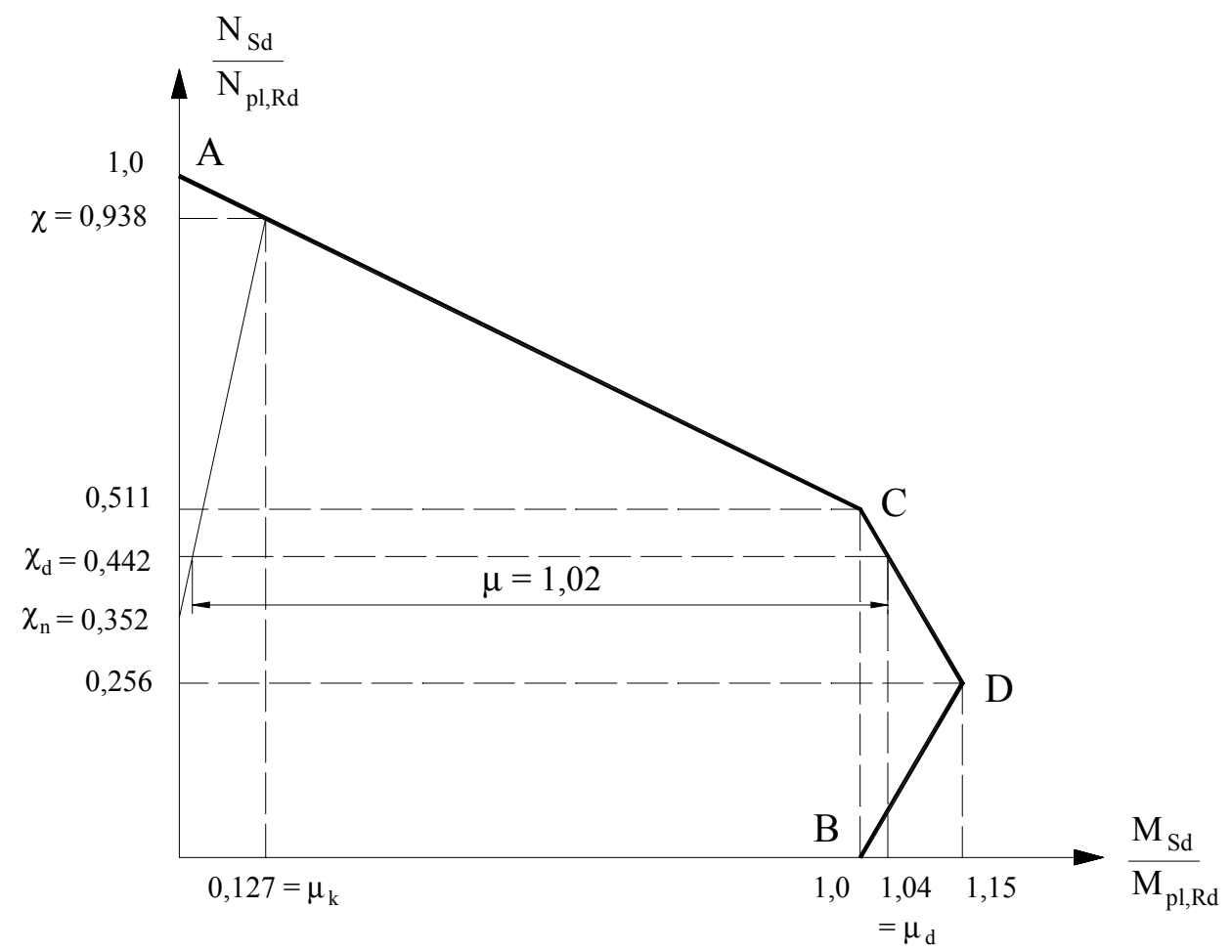

FIGURA 7.7: Curva de interação momento-normal - exemplo 3

$$
N_{s d}=1.500 \mathrm{kN}
$$

Substituindo valores:

$$
\begin{aligned}
& \mu=1,04-0,127 \times \frac{(0,442-0,352)}{(0,938-0,352)}=1,02 \\
& M_{S d} \leq 0,9 \times 1,02 \times 21.288=19.542 \mathrm{kN} . \mathrm{cm}
\end{aligned}
$$

A condição acima indica que o momento fletor solicitante de cálculo, obtido em segunda ordem, não deve ser maior que 19.542 kN.cm.

Neste exemplo, houve predominância do momento fletor na flexo-compressão. Considerando agora, a título de ilustração, que a normal solicitante de cálculo assumisse o valor:

$N_{S d}=2.500 \mathrm{kN}$

Por meio curva de interação momento-normal da figura 7.8 , pode-se obter o novo limite para o momento solicitante de cálculo: 


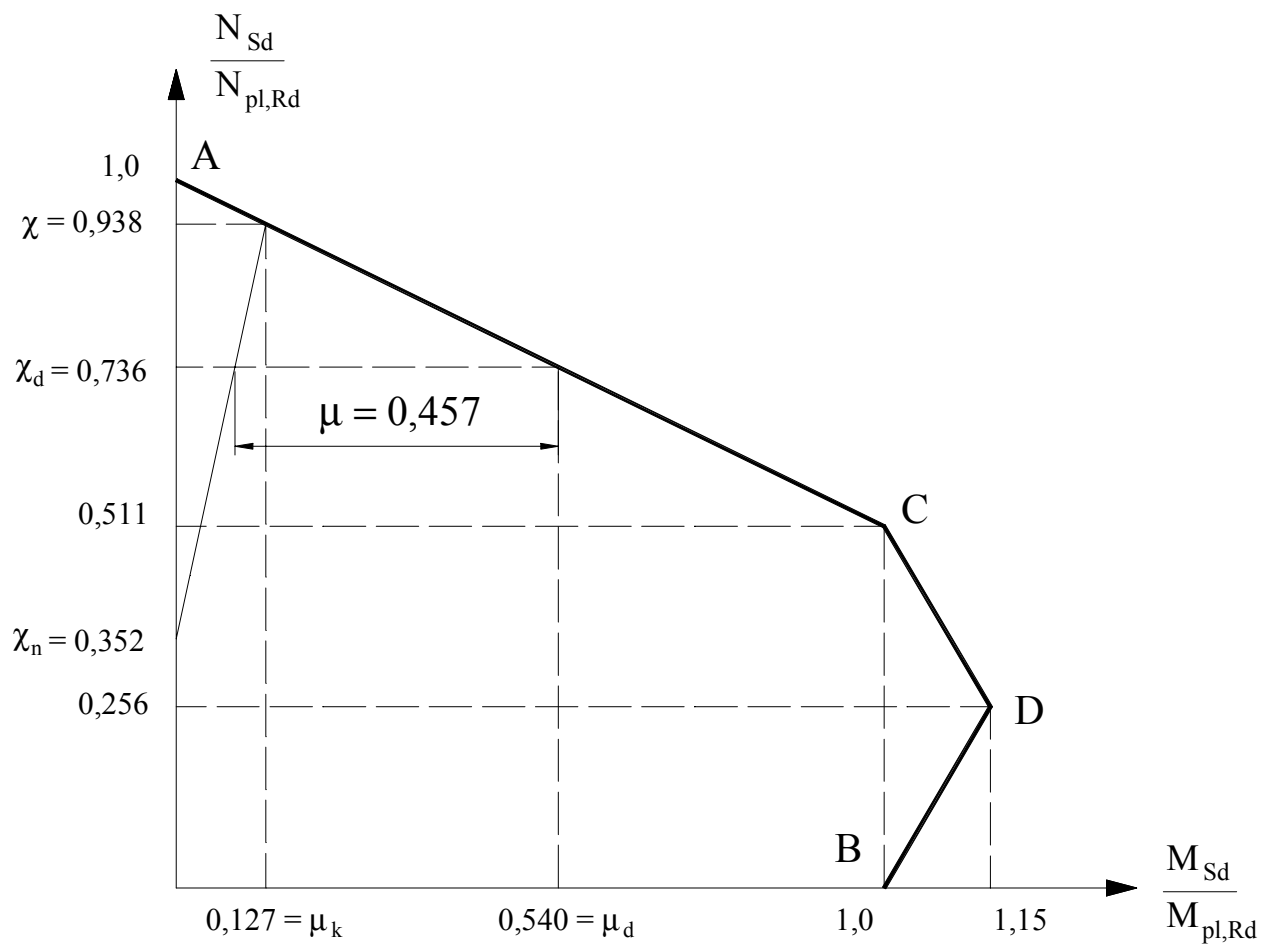

FIGURA 7.8: Curva de interação momento-normal - exemplo 3

$$
N_{s d}=2.500 \mathrm{kN}
$$

onde

$$
\begin{aligned}
& \chi_{d}=\frac{2.500}{3.395}=0,736 \Rightarrow \mu_{d}=0,540 \\
& \mu=\mu_{d}-\mu_{k} \frac{\left(\chi_{d}-\chi_{n}\right)}{\left(\chi-\chi_{n}\right)}=0,540-0,127 \times \frac{(0,736-0,352)}{(0,938-0,352)}=0,457 \\
& M_{S d} \leq 0,9 \mu M_{p l, R d}=0,9 \times 0,457 \times 21.288 \\
& M_{S d} \leq 8.756 \mathrm{kN} . \mathrm{cm}
\end{aligned}
$$




\section{CONSIDERAÇÕES FINAIS}

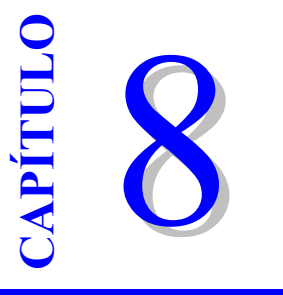

\subsection{CONCLUSÕES}

As estruturas mistas aço-concreto, formadas pela associação de perfis de aço com o concreto, constituem uma solução competitiva em sistemas estruturais de edifícios e pontes, sendo bastante empregadas em diversos países. O emprego do sistema misto no Brasil é relativamente recente e tem evoluído de forma modesta.

Nos sistemas horizontais, constituídos principalmente de lajes e vigas, a utilização de elementos mistos conduz a algumas vantagens, entre elas a rapidez de execução e o significativo aumento da capacidade estrutural das vigas, resultando em economia de material. Nesses sistemas, as vigas mistas e as lajes com fôrma de aço incorporada, caracterizando as lajes mistas, são bem utilizadas. Nos sistemas verticais, os pilares mistos têm tido sua utilização ampliada, principalmente em edifícios altos. Nesses elementos mistos, a combinação aço-concreto propicia maior rigidez à estrutura e maior resistência ao fogo.

Os conectores de cisalhamento, responsáveis pela ligação entre o elemento de aço e o concreto, foram objeto de diversas pesquisas, principalmente no que se refere à sua capacidade e ductilidade, avaliada por meio de ensaios padronizados que estabelecem a curva força-escorregamento relativo. As principais normas apresentam expressões para o cálculo da capacidade de alguns tipos de conectores, as quais derivam de resultados experimentais.

O comportamento estrutural das vigas mistas simplesmente apoiadas já é bem conhecido. Existem pesquisas recentes, entretanto, que procuram fazer uma avaliação mais precisa de parâmetros que são relevantes no comportamento de vigas 
mistas. Entre esses parâmetros, estão o efeito da interação parcial aço-concreto, a obtenção da largura efetiva da laje e o efeito da fluência e da retração do concreto.

O dimensionamento de vigas mistas submetidas a momentos positivos é tratado por todas as normas. De maneira geral, essas normas apresentam procedimentos de cálculo e hipóteses comuns entre si. Entre esses aspectos comuns, cita-se a distribuição de tensões a ser admitida na determinação da resistência ao momento fletor, em função da relação largura/espessura da alma do perfil de aço: admite-se a plastificação total para almas "compactas", ao passo que se admite a distribuição elástica de tensões para almas "esbeltas". Outro aspecto é o efeito da interação parcial sobre os deslocamentos verticais: devido ao escorregamento relativo ao nível da conexão aço-concreto, esses deslocamentos sofrem um acréscimo, o qual é considerado pelas normas mediante uma redução no momento de inércia da seção homogeneizada. Observa-se também que as normas recomendam um valor mínimo para o grau de conexão no caso de interação parcial, variando entre 0,45 e 0,6 para vãos usuais de edifícios (7 à $12 \mathrm{~m}$ ). O dimensionamento depende também do processo construtivo empregado, devendo-se fazer verificações adicionais das tensões atuantes e dos deslocamentos na viga de aço isolada, no caso de construção não escorada.

Com relação às vigas mistas simplesmente apoiadas ainda, podem ser feitas algumas observações. Uma delas está relacionada com o tipo de interação. A diferença entre os momentos resistentes obtidos da interação completa e da interação parcial é relativamente pequena. Em se tratando de deslocamentos, a diferença também não é muito significativa entre os dois casos de interação: verifica-se um acréscimo de 15 à $25 \%$ devido ao efeito de interação parcial. A interação momentocortante, cuja verificação é recomendada pelo EUROCODE 4 (1992), não é crítica em vigas simplesmente apoiadas, sendo, porém, mais crítica em vigas contínuas, pois nos apoios internos, os esforços cortantes são maiores e a resistência ao momento fletor, menor.

Com relação às vigas mistas contínuas, existem fatores adicionais a serem analisados quando comparados às vigas simplesmente apoiadas, devido à fissuração do concreto e a instabilidade da viga de aço em regiões de momentos negativos. A NBR 8800 (1986) não aborda o caso de vigas mistas contínuas, devendo-se 
considerar apenas a viga de aço isolada no dimensionamento, o que representa um procedimento conservador, conforme comprovado no exemplo 2. Entre as normas pesquisadas, o EUROCODE 4 (1992) é a que fornece um tratamento mais detalhado às vigas mistas contínuas. Podem ser destacadas duas particularidades do comportamento de vigas contínuas, e que são apresentadas pela norma européia. A primeira delas é a obtenção dos esforços solicitantes a partir da redistribuição de momentos, devido à perda de rigidez à flexão nas regiões de momento negativo, onde ocorre a fissuração do concreto. A segunda diz respeito à verificação da estabilidade lateral: os procedimentos de cálculo são similares aos apresentados para as vigas de aço isoladas no EUROCODE 3 (1992).

Percebe-se que o momento resistente na região dos apoios é menor que o momento resistente nas regiões de momento positivo, mesmo considerando a contribuição da armadura. Os deslocamentos em vigas contínuas são menores que nas vigas simplesmente apoiadas correspondentes, mesmo admitindo a fissuração do concreto na região dos apoios.

As pesquisas relacionadas ao comportamento estrutural das lajes mistas são relativamente recentes. Dessa maneira, encontrou-se um número menor de pesquisas em relação às vigas e os pilares mistos. O EUROCODE 4 (1992) foi a norma abordada neste texto, pois trata de todos os estados limites últimos e de utilização relevantes no dimensionamento de lajes mistas. No Brasil, a utilização desse sistema é recente. Embora a NBR 8800 (1986) não faça referência a esses elementos, a norma NBR 14323 (1999) trata do dimensionamento de lajes com fôrma de aço incorporada em temperatura ambiente e em situação de incêndio, com base nas recomendações da norma européia.

O dimensionamento de lajes mistas depende de alguns parâmetros obtidos por meio de ensaios, como é o caso da determinação da resistência ao cisalhamento longitudinal e da força de deslizamento inicial de extremidade . Algumas pesquisas propõem alternativas sobre métodos de ensaio e procedimentos de cálculo, visando um melhor entendimento do comportamento da laje mista e dos parâmetros que afetam o projeto.

Existem diversas pesquisas referentes ao comportamento estrutural dos pilares mistos. Tais pesquisas consistem basicamente na identificação de parâmetros 
que interferem na capacidade resistente e como esta interferência ocorre. Estes trabalhos, de maneira geral, buscam confrontar estudos teóricos e experimentais, questionando também a formulação adotada pelas normas que abordam o dimensionamento de pilares mistos. Alguns pontos, entretanto, necessitam ser melhor estudados, entre eles, avaliar quantitativamente o efeito do confinamento do concreto na capacidade do pilar preenchido. Outro ponto a ser estudado e que envolve os pilares mistos são os dispositivos de ligação entre estes e as vigas, pois há um escasso conhecimento sobre o assunto.

Os dois principais tipos de pilares mistos oferecem vantagens: no pilar revestido, além da proteção ao fogo e do aumento da resistência do pilar, a presença do concreto como revestimento impede a flambagem local dos elementos que compõem o perfil de aço. No pilar preenchido, a principal vantagem é a possibilidade de dispensar fôrmas e armadura, além da consideração benéfica do efeito de confinamento do concreto em pilares preenchidos circulares.

As principais normas apresentam filosofias diferentes quanto ao dimensionamento dos pilares mistos. Algumas normas os consideram como pilares de aço com maior capacidade estrutural, devido à presença do concreto; outras os consideram como pilares de concreto armado com armadura especial, devido à presença do perfil de aço. A norma brasileira NBR 8800 (1986) não aborda os pilares mistos. No entanto, a NBR 14323 (1999) trata do dimensionamento dos pilares mistos tanto em temperatura ambiente quanto em situação de incêndio.

Com relação ao comportamento estrutural em situação de incêndio, pode-se afirmar que o principal efeito das temperaturas elevadas sobre o aço e o concreto é a alteração das propriedades mecânicas desses materiais, reduzindo suas resistências. A principal característica do incêndio, em termos de análise estrutural, é a curva que fornece a temperatura dos gases quentes no compartimento em chamas, em função do tempo de duração do incêndio, denominada curva tempo-temperatura. A partir dessa curva, é possível determinar a máxima temperatura atingida pelo elemento estrutural e, consequentemente, obter sua resistência ao incêndio. Devido à dificuldade de se estabelecer a curva tempo-temperatura de uma situação real de incêndio, as principais normas que abordam o assunto adotam curvas padronizadas, denominadas curvas de incêndio padrão. Estas, apesar de conduzirem a um 
dimensionamento mais conservador, são de utilização prática em projeto. Um ponto, entretanto, que merece ser melhor analisado, é o preestabelecimento de um período fictício de dimensionamento, denominado tempo de resistência ao fogo, cujo valor permite encontrar a temperatura do elemento estrutural por meio da curva padrão.

A norma brasileira NBR 14323 (1999), aprovada recentemente, trata do dimensionamento de estruturas de aço submetidas a altas temperaturas, inclusive os elementos mistos, tais como vigas, lajes e pilares. Esta norma procurou uniformizar os procedimentos de cálculo com a NBR 8800 (1986) e a NBR 8621 (1984).

\subsection{SUGESTÕES PARA NOVAS PESQUISAS}

Com base na revisão bibliográfica realizada, apresentam-se algumas sugestões para trabalhos futuros:

- Avaliação da variação de rigidez de uma viga mista contínua em regiões de momento fletor negativo, em função da fissuração do concreto, taxa de armadura, etc.

- Análise do comportamento de ligações flexíveis viga-pilar considerando a contribuição da armadura da laje, implicando em ligações semi-rígidas.

- Pesquisa sobre novos mecanismos de ligação mecânica entre a fôrma de aço e o concreto, avaliando-se a influência sobre a resistência da laje mista.

- Estudo sobre os pilares mistos parcialmente revestidos, pois poucas pesquisas foram encontradas em relação a esses tipos de pilares. Além disso, as principais normas não abordam os pilares mistos parcialmente preenchidos (exceto o EUROCODE 4).

- Investigação mais profunda sobre a transferência de esforços cisalhantes na interface aço-concreto de pilares mistos, contribuindo para a sua consideração em projeto. 


\section{REFERENNCIAS BIBLIOGRÁFICAS}

AMERICAN CONCRETE INSTITUTE (1992). ACI 209R-92 - Designing for the effects of creep, shrinkage, and temperature in concrete structures. Detroit.

AMERICAN CONCRETE INSTITUTE (1992). ACI 318R-92 - Building code requirements for reinforced concrete. Detroit.

AMERICAN CONCRETE INSTITUTE (1995). ACI 318R-95 - Building code requirements for reinforced concrete. Detroit.

AMERICAN INSTITUTE OF STEEL CONSTRUCTION (1994). AISC-LRFD - Load and resistance fator design. Chicago.

AMERICAN SOCIETY TESTING AND MATERIALS (ASTM E119) (1988). Standard test methods for fire tests of building constructions and material.

ASSOCIAÇÃO BRASILEIRA DE NORMAS TÉCNICAS (1999). NBR 14323 Dimensionamento de estruturas de aço de edifícios em situação de incêndio. Rio de Janeiro.

ASSOCIAÇÃO BRASILEIRA DE NORMAS TÉCNICAS (1986). NBR 8800 - Projeto e execução de estruturas de aço de edifícios. Rio de Janeiro.

AZIZINAMINI, A.; PRAKASH, B. (1993). A tentative design guideline for a new steel connection detail to composite tube column. Engineering Journal, v.31, n.1, p.108-15, $3 \%$.

BAEHRE, ROLF et al. (1993). Cold formed steel in tall buildings: Council on tall buildings and urban habitat, Bethlehem, Comittee S37.

BRITISH STANDARD INSTITUTION (1979). BS 5400 - Steel, concrete and composite bridges. Parte 5: Code of practice for design of composite bridges. London.

BRITISH STANDARD INSTITUTION (1986). BS 8110 - The structural use of concrete. London.

BRITISH STANDARD INSTITUTION (1990). BS 5950 - Structural use of steelwork in building. Parte 3: Section 3.1: Code of practice for design of simple and continuous composite beams. London. 
BROSNAN, D.P.; UANG,C. (1995). Effective Width of Composite L-Beams in Buildings. Engineering Journal, v.32, n.2, p.73-80.

CANADIAN STANDARDS ASSOCIATION (1994). CAN/CSA-S16.1-94 - Limit States Design of Steel Structures. Toronto, Ontario.

CODEME ENGENHARIA S.A. (1997). Steel Deck CE-75: Noções de utilização e Dimensionamento. Betim.

CORRÊA, M.R.S. (1991). Aperfeiçoamento de modelos usualmente empregados no projeto de sistemas estruturais de edifícios. São Carlos 331p. Tese (Doutorado) - Escola de Engenharia de São Carlos, Universidade de São Paulo.

CRISINEL, M.; O’LEARY, D. (1996). Composite floor slab design and construction. Structural Engineering International, v.6, n.1, p.41-6, february.

DANIELS, B.J. ; CRISINEL, M. (1993). Composite Slab Behavior Strength Analysis. Parte I: Calculation Procedure. Journal of Structural Engineering, v.119, n.1, p.16-35, january.

DANIELS, B.J. ; CRISINEL, M. (1993). Composite Slab Behavior Strength Analysis. Parte II: Comparison with Test Results and Parametric Analysis. Journal of Structural Engineering, v.119, n.1, p.36-49, january.

DE NARDIN, S. (1999). Estudo teórico-experimental de pilares mistos compostos por tubos de aço preenchidos com concreto de alta resistência. São Carlos. 148p. Dissertação (Mestrado) - Escola de Engenharia de São Carlos. Universidade de São Paulo.

DEKKER, N.W.; KEMP, A. R.; TRINCHERO, P. (1995). Factors Influencing the Strength of Continuous Beams in Negative Bending. Journal of Constructional Steel Research, v.34, n.2-3, p.161-65.

DIAS, L.A.M. (1993). Edificações de aço no Brasil. São Paulo, Zigurate.

DIAS, L.A.M. (1998). Estruturas de aço: Conceitos, técnicas e linguagem. São Paulo, Zigurate.

DISSANAYAKE, U.I.; DAVISON, J.B.; BURGESS, I.W. (1998). Limit State Behaviour of Composite Frames. Journal of Constructional Steel Research, v.46, n.1-3, paper n.71.

EASTERLING, W.S.; YOUNG, C.S. (1992). Strength of Composite Slabs. Journal of Structural Engineering, v.118, n.9, p.2370-89, september. 
EUROPEAN COMMITTEE FOR STANDARDIZATION (1991). ENV 1992-1-1: Eurocode 2 - Design of concrete structures. Part 1-1: General rules and rules for buildings. Brussels.

EUROPEAN COMMITTEE FOR STANDARDIZATION (1992). ENV 1993-1-1: Eurocode 3 - Design of steel structures. Part 1-1: General rules and rules for buildings. Brussels.

EUROPEAN COMMITTEE FOR STANDARDIZATION (1992). ENV 1994-1-1: Eurocode 4 - Design of composite steel and concrete structures. Part 1-1: General rules and rules for buildings. Brussels.

EUROPEAN COMMITTEE FOR STANDARDIZATION (1994). ENV 1994-1-2: Eurocode 4 - Design of composite steel and concrete structures. Part 1-2: General rules. Structural fire design. Brussels.

EUROPEAN CONVENTION FOR CONSTRUCTIONAL STEELWORK (ECCS) (1981). Composite Structures. London, The Construction Press.

EUROPEAN CONVENTION FOR CONSTRUCTIONAL STEELWORK (ECCS) (1993). Composite Beams and Columns to Eurocode 4. Brussels, ECCS.

EUROPEAN CONVENTION FOR CONSTRUCTIONAL STEELWORK (ECCS) (1985). Design manual on European Recomendations for the fire safety of steel structures. Brussels, ECCS.

FIGUEIREDO, L.M.B. (1998). Projeto e construção de pilares mistos aço-concreto. São Carlos. 142p. Dissertação (Mestrado) - Escola de Engenharia de São Carlos, Universidade de São Paulo.

GILBERT, R.I.; BRADFORD, M.A. (1995). Time-dependent behaviour of continuous composite beams at service loads. Journal of Structural Engineering, v.121, n.2, p.31927 , february.

HACKETT \& ASSOCIATES (1998). Products: shear connectors. http://www.hackettassociates.com (19 ago/99).

HAMERLINCK, R.; TWILT, L. (1995). Fire resistance of composite slabs. Journal of Constructional Steel Research, v.33, n.1-2, p.71-85.

HART, F.; HENN, W.; SONTAG, H. (1985). Multi-storey building in steel. 2.ed. New York, Nichols Publishing. 
INTERNATIONAL STANDARDIZATION FOR ORGANIZATION (ISO 834) (1994). Fire resistance tests - Elements of building construction. Genève.

JASIM, N.A.; ALI, A.A.M. (1997). Deflections of composite beams with parcial shear connection. The Structural Engineer, v.75, n.4, p.58-61, 18 feb.

JOHNSON, R.P. (1994). Composite structures of steel and concrete, v.1, 2.ed. Oxford, Blackwell Scientific Publications.

KATO, B. (1996) Column curves of steel-concrete composite members. Journal of Constructional Steel Research, v.39, n.2, p.121-35, september.

KODUR, V.K.R. (1999). Performance-based fire resistance design of concrete-filled steel columns. Journal of Constructional Steel Research, v.51, n.1, p.21-36, july.

KRUPPA, J.; ZHAO, B. (1995). Fire Resistance of composite beams to EUROCODE 4: Part-1.2. Journal of Constructional Steel Research, v.33, n.1-2, p.51-69.

LAWSON, R.M. (1990). Behaviour of steel beam-to-column connections in fire. The Structural Engineering. v.68, n.14, p.263-71, july.

LIE, T.T.; KODUR, V.K.R. (1996). Fire resistance of steel columns filled with barreinforced concrete. Journal of Structural Engineering, v.122, n.1, p.30-6, january.

LIE, T.T.; STRINGER, D.C. (1994). Calculation of the fire resistance of steel hollow structural section columns filled with plain concrete. Canadian Journal of Civil Engineering, v.21, n.3, p.382-85, june.

MALITE, M. (1990). Sobre o cálculo de vigas mistas aço-concreto: ênfase em edifícios. São Carlos. 144p. Dissertação (Mestrado) - Escola de Engenharia de São Carlos. Universidade de São Paulo.

MALITE, M. (1993). Análise do comportamento estrutural de vigas mistas aço-concreto constituidas por perfis de chapa dobrada. São Carlos. 2v. Tese (Doutorado) - Escola de Engenharia de São Carlos. Universidade de São Paulo.

MALITE, M.; NIMIR, W.A.; SÁLES, J.J.;GONÇALVES, R.M. (1998). Cold-Formed Shear Conectors for Composite Construction. In: INTERNATIONAL CONFERENCE ON COLD-FORMED STEEL STRUCTURES, 14., St. Louis, 1998. Anais. St Louis, UMR, p.409-21. 
MELO, C.B.F. (1999). Análise do comportamento e da resistência do sistema de lajes mistas. Belo Horizonte. 145p. Dissertação (Mestrado) - Escola de Engenharia. Universidade Federal de Minas Gerais.

MIRZA, S.A.; TIKKA, T.K. (1999) Flexural stiffness of composite columns subjected to major axis bending. ACI Structural Journal, v.96, n.1, p.19-28, jan/feb.

MUÑOZ, P.R; HSU, C-T.T. (1997a) Behaviour of biaxially loaded concrete-encased composite columns. Journal of Structural Engineering, v.123, n.9, p.1163-71, september.

MUÑOZ, P.R; HSU, C-T.T. (1997b) Biaxially loaded concrete-encased composite columns: Design equation. Journal of Structural Engineering, v.123, n.12, p.1576-85, december.

OEHLERS, D.J.; COUGHLAN, C.G. (1986). The shear stiffness of stud shear connectors in composite beams. Journal of Constructional Steel Research, v.6, n.4, p.273-84, october.

OEHLERS, D.J.; NGUYEN, N.T.; AHMED, M.; BRADFORD, M.A. (1997). Partial Interaction in Composite Steel and Concrete Beams with Full Shear Connection. Journal of Constructional Steel Research, v.41, n.2/3, p.235-48, feb/mar.

OEHLERS, D.J.; SVED, G. (1995). Composite Beams with Limited-Slip Capacity Shear Connectors. Journal of Structural Engineering, v.121, n.6, p.932-8, june.

PATRICK, M. (1990). A New Partial Shear Connection in Strength Model for Composite Slabs. Steel Constr. J. , Austr. Inst. of Steel Constr., v.24, n.3, p.2-17.

PATRICK, M. (1991). Slip Block Test Results for Bondek II Profiled Steel Sheeting. BHP Research, Melbourne Laboratories Rep. BHPRML/PS64/91/002, june.

PATRICK, M. ; BRIDGE, R.Q. (1994). Partial Shear Connection Design of Composite Slabs. Engineering Structures, v.16, n.5, p.348-62.

SÁLES, J.J. (1995). Estudo do projeto e construção de edifícios de andares múltiplos com estruturas de aço. São Carlos. 257p. Tese (Doutorado) - Escola de Engenharia de São Carlos. Universidade de São Paulo.

SALMON, C.G.; JOHNSON, J.E. (1990). Steel structures: Design e Behavior. 3.ed. New York, Harper \& Row.

SCHNEIDER, S.P. (1998) Experimental behaviour of connections to concrete-filled steel tubes. Journal of Constructional Steel Research, v.45, n.3, p.321-52, mar. 
SHAKER, A.F.; KENNEDY, D.J.L. (1983). The effective modulus of elasticity of concrete in tension. Structural Engineering, report 172.

SILVA, V.P. (1997). Estruturas de aço em situação de incêndio. São Paulo. 170p. Tese (Doutorado) - Escola Politécnica. Universidade de São Paulo.

THE STEEL CONSTRUCTION INSTITUTE (1992). Steel Designer's Manual. 5.ed. Oxford, Blackwell Scientific Publications.

UNITED STEEL DECK INC. (1997). Steel Deck for floors and roofs. http://www.njbunited.com/usd/metric97.htm. (25 mar/99).

UY, B. (1998) Local and post-local buckling of concrete-filled steel welded box columns. Journal of Constructional Steel Research, v.47, n.1-2, p.47-72.

UY, B.; Das S. (1997). Wet concrete loading of thin-walled steel box columns during the construction of a tall building. Journal of Constructional Steel Research, v.42, n.2, p.95119.

VALLENILLA, C.R.; BJORHOVDE, R. (1990). Behaviour of composite frames during construction. Journal of Constructional Steel Research, v.15, n.1-2, p.3-21.

WANG, Y.C. (1999) Tests on slender composite columns. Journal of Constructional Steel Research, v.49, n.1, p.25-41, jan.

WIUM, J.A.; LEBET, J.P. (1994). Simplified calculation method for force transfer in composite columns. Journal of Structural Engineering, v.120, n.3, p.728-46, mar.

WILLIAMS, F.W.; JEMAH, A.K.; LAM, D.H. (1993). Distorcional buckling curves for composite beams. Journal of Structural Engineering, v.119, n.7, p.2134-49, july.

WRIGHT, H.D.; VITEC, J.L.; RAKIB, S.N. (1992). Long-term creep and shrinkage in composite beams with parcial connection. Proceedings of the Institute Civil Engineers Structs \& Bldgs, v.94, p.187-95, may.

YENGAR, S.H.; IQBAL, M.; (1987). Composite Construction. In: WHITE, R.N.; SALMON, C.G., eds. Building Structural Design Handbook. New York, John Willey \& Sons. Cap.3, p.787-820. 